A Comparative Foreign Policy Analysis of Weak States:

The Case of the Caucasus States

\title{
Yasar Sari
}

Charlottesville, Virginia

B.A., Istanbul University, 1993

M.A., Old Dominion University, 1997

A Dissertation presented to the Graduate Faculty of the University of Virginia in Candidacy for the Degree of Doctor of Philosophy

The Woodrow Wilson Department of Politics

University of Virginia

December 2008

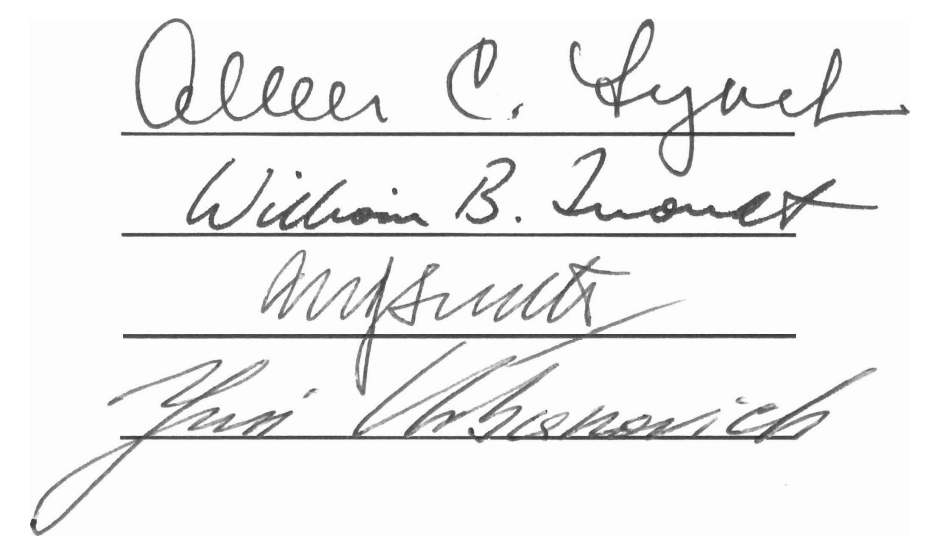




\begin{abstract}
Keywords: Caucasus states, Russia, foreign policy analysis, weak state

The key features of foreign policy formulation and execution in Armenia, Azerbaijan and Georgia are selected in an attempt to reveal the sources of foreign policy-behavior of new, postSoviet (and in effect post-imperial) states during the 1990s. More specifically, this is a comparative study of the foreign policies of the Caucasus states as new states toward the Russian Federation as the ex-imperial center.

The purpose of the dissertation is to verify the relative significance of internal factors and level of external assistance in shaping the foreign policy of weak states. Therefore, the key theoretical contribution of the dissertation is to understand foreign policy change in weak states during their early years of independence.
\end{abstract}

The newly independent Caucasus states are weak states. The most urgent problems facing these newly independent states following their independence were domestic ones. The time period covered is between 1991 and 1999, which in turn is divided into two sub-periods: 19911995, the period of confusion and 1995 to 1999, the period of consolidation.

This dissertation centers upon the explanation of two factors: the level of domestic strain of weak states and their relations to the external world. In short, both domestic and external factors influence the strength of the independent variables which in turn serve as the principal explanatory elements and determinant of the foreign policy-behavior of weak states.

Therefore, the weak state foreign policy behavior is best explained based on the interaction of four different variables: the strength of the new state, the role of leadership or orientation of the leaders, type of threats and external support to the new states. Moreover, these 
states have three possible alternative relationship with the former imperial center: balancing, bandwagoning, and omnibalancing. 


\section{Acknowledgments}

I owe a huge debt of gratitude to professors, friends, colleagues, and students for inspiring me and helping me complete this dissertation. I would like to express my sincere gratitude to my dissertation supervisor, mentor, and Chair, Professor Allen C. Lynch, whose wise counsel, support and patience over the years was crucial to this work. I also greatly appreciate his encouragement in helping me to view my dissertation with a critical eye.

I am very grateful to my Committee Members, Professors William B. Quandt, Michael Smith, and Yuri Urbanovich for their invaluable feedback and advice. I would also like to thank Professor Urbanovich and his wife Angelina for their moral support. They become my family in Charlottesville.

I am also very grateful to Professor Vamik Volkan for both his moral support and wise advice in the process.

I warmly thank my friends and colleagues at the University of Virginia, Karadeniz Technical University, Osh Technological University, Kyrgyz-Turkish Manas University, American University of Central Asia, and International Ataturk Alatoo University (IAAU), for their support of me in this work over the years, including Professor Erol Oral, Rector of IAAU, Professor Hayati Aktas, Dr. Osman Kadi, Halim Nezihoglu, Ismail Soygenis, Dr. Umut Uzer, Yakup Asarkaya, Rasit Telbisoglu, Supad Ghose Kumar, Dr. Djalalidin Djenbaev, Talant Turdaliev, Nadira Myrzalieva, Ikbol Tashpolatov, and Steve On, among others.

Particularly thanks are due to three friends without their assistance and moral support this dissertation would not have been completed: Seyit Ali Avcu, Sureyya Yigit and W. Scott Willis. They helped me at various times with their invaluable assistance and moral support.

In summer 2008, I stayed two months at Professor William B. Quandt's and Mrs. Helena Cobban's home. Mrs. Cobban told me that she wrote four books on the desk on which I was working for my dissertation. I would like to thank them providing a quiet place of study. Hopefully, in the near future, my dissertation may turn into a book.

Finally, my family sustained me through some very tough times. I am especially indebted to my parents, Emine and Mustafa Sari, my wife, Samara Turdalieva-Sari as well as my sister and brothers for their moral support and understanding. I would especially like to thank my parents and my wife, without whose loving encouragement, assistance, support and patience this dissertation would never have been finished.

I apologize in advance for any inadvertent omission of anyone I should have acknowledged. 


\section{Table of Contents}

A. Chapter I- Introduction

1. Subject

2. Definitions

3. Research Questions

4. Literature Review

5. Methodological Framework

6. Organization of Study

7. Boundaries of Subject

B. Chapter II- A Theoretical Framework for Weak States' Foreign Policy 56

1. Introduction $\quad 56$

2. Independent Variables $\quad 60$

a. Weak State 60

b. Origins of Threats 68

c. External Assistance 71

d. Leaders 75

3. Dependent Variables 79

a. Balance of Power/Threat 80

b. Bandwagoning 81

c. Omnibalancing 83

4. Building a Theoretical Framework to Understand Foreign Policies of Weak States 85

a. Hypotheses and Arguments 90

5. Applying Foreign Policy Models to the Caucasus States 96

C. Chapter III- Foreign Policy-Making in the Caucasus 108

$\begin{array}{ll}\text { 1. Introduction } & 108\end{array}$

2. The Caucasus: General 110

a. Strength of States 110

b. Threats 122

c. Leadership 124

d. External Influence 127

e. Conclusion 139

3. Armenia 142

a. Strength of State 142

b. Threats 151

c. Leadership 158

d. External Influence 162

e. Conclusion 168

4. Azerbaijan 171

a. Strength of State 171

$\begin{array}{ll}\text { b. Threats } & 179\end{array}$

$\begin{array}{ll}\text { c. Leadership } & 187\end{array}$

d. External Influence 194

e. Conclusion 204 
5. Georgia 206

a. Strength of State 206

b. Threats 215

c. Leadership 221

d. External Influence 228

e. Conclusion 235

6. Conclusion 237

D. Chapter IV- Foreign Policy-Behavior in the Caucasus 241

1. Introduction 241

2. The Caucasus: General 245

3. Armenia 251

a. Foreign Policy Making Process 251

b. Leadership Perceptions on Foreign Policy 262

c. Armenia and Russia 274

d. Other Players 279

e. Conclusion 287

4. Azerbaijan 291

a. Foreign Policy Making Process 291

b. Leadership Perceptions on Foreign Policy 304

c. Azerbaijan and Russia 316

d. Other Players 323

e. Conclusion 336

5. Georgia 342

a. Foreign Policy Making Process 342

b. Leadership Perceptions on Foreign Policy 354

c. Georgia and Russia 363

d. Other Players 371

e. Conclusion 375

6. The Caucasus and Russia 378

7. Conclusion 390

E. Chapter V- Conclusion 395

$\begin{array}{ll}\text { F. Bibliography } & 411\end{array}$ 


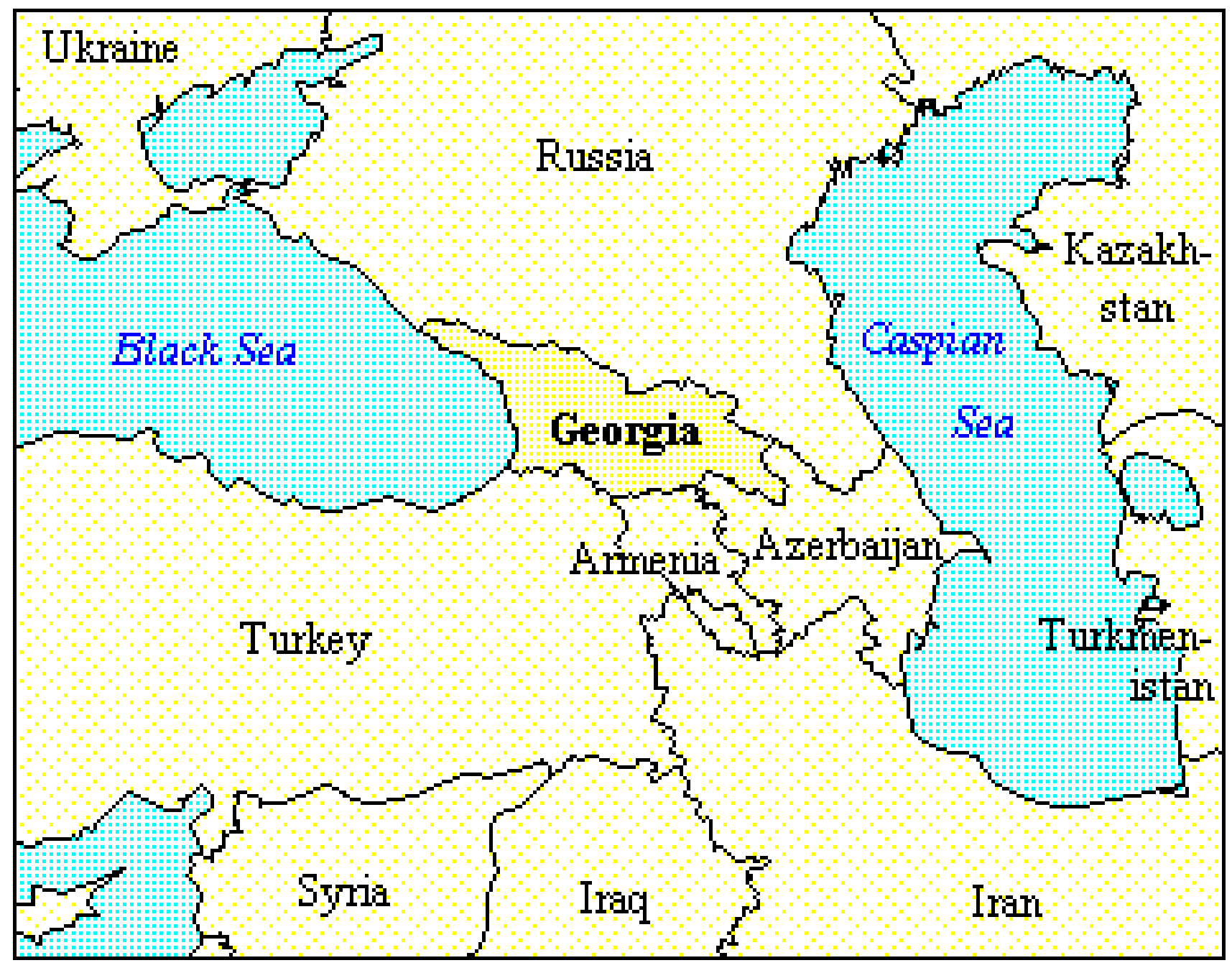




\section{(4) Caucasus}

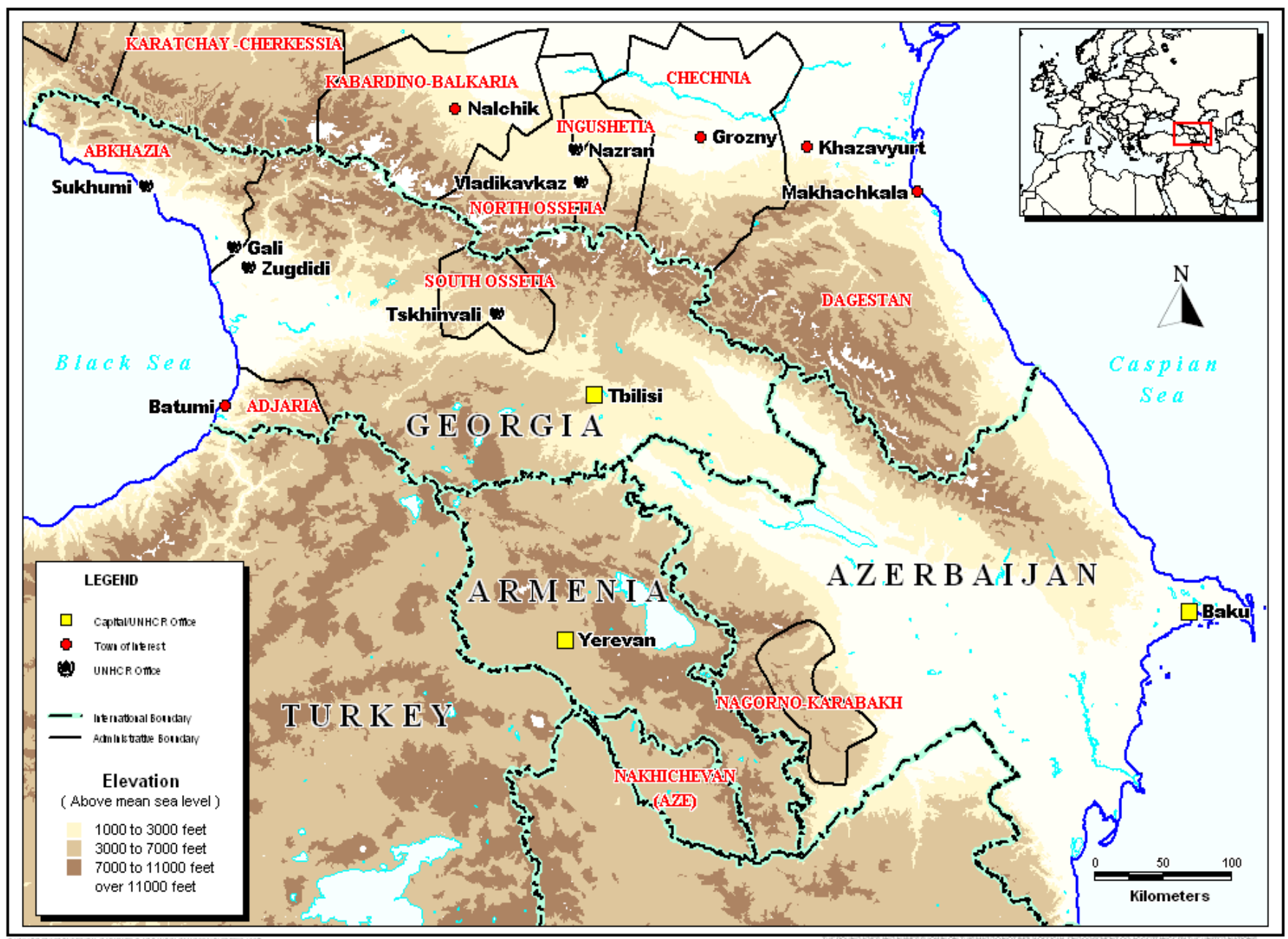




\section{Baku-Tbilisi-Ceyhan Pipeline}

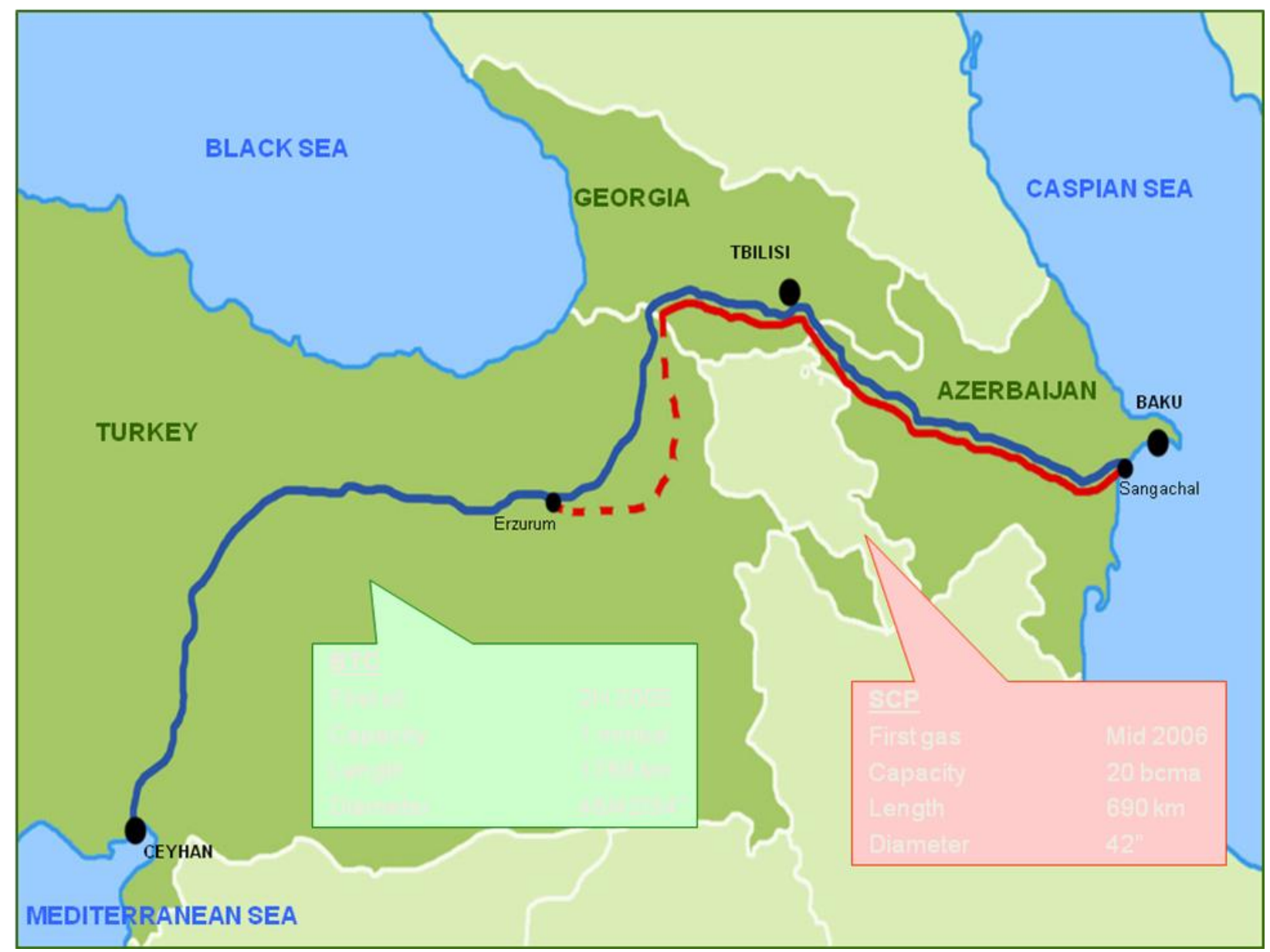


Main Regional Energy Projects

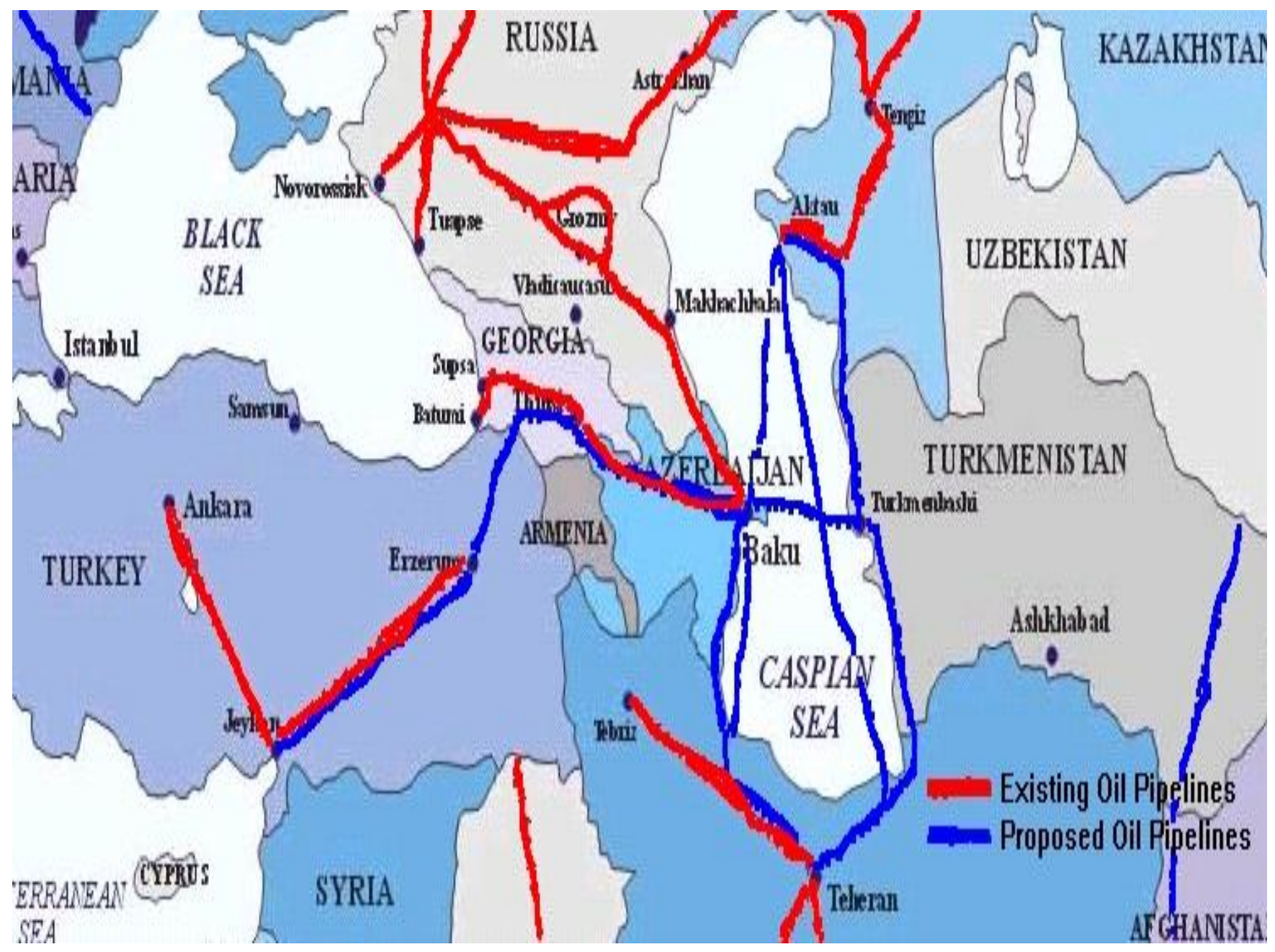




\section{Chapter I}

\section{Subject}

This is a comparative study of the foreign policies of Armenia, Azerbaijan and Georgia toward the Russian Federation in an attempt to elucidate the sources of foreign policy-behavior of new, post-Soviet (and in effect post-imperial) states. The purpose of this dissertation is to determine the relative significance of internal factors in shaping foreign policy in ways that tend to be overlooked by mainstream theories of International Relations and Foreign Policy Analysis. In chapter I, I will define the conceptual parameters and the research borders and scope of my subject.

In this dissertation, I will explain the behaviors of new state foreign policies as reflecting the interaction of four variables: the strength of the new state, the role of leadership or orientation of the leaders, type of threats and external support to the new $\underline{\text { states. }}$

I also argue that in focusing on their foreign policies, new states have three options when they deal with their former imperial center: balancing, bandwagoning, and omnibalancing. My cases are the relations between Armenia, Azerbaijan and the Republic of Georgia, considered as new states, with the Russian Federation, considered as a former imperial power, from 1991 to 1999 . These relationships may be represented schematically as follows:

\section{Independent Variables Intervening Variable Dependent Variables}

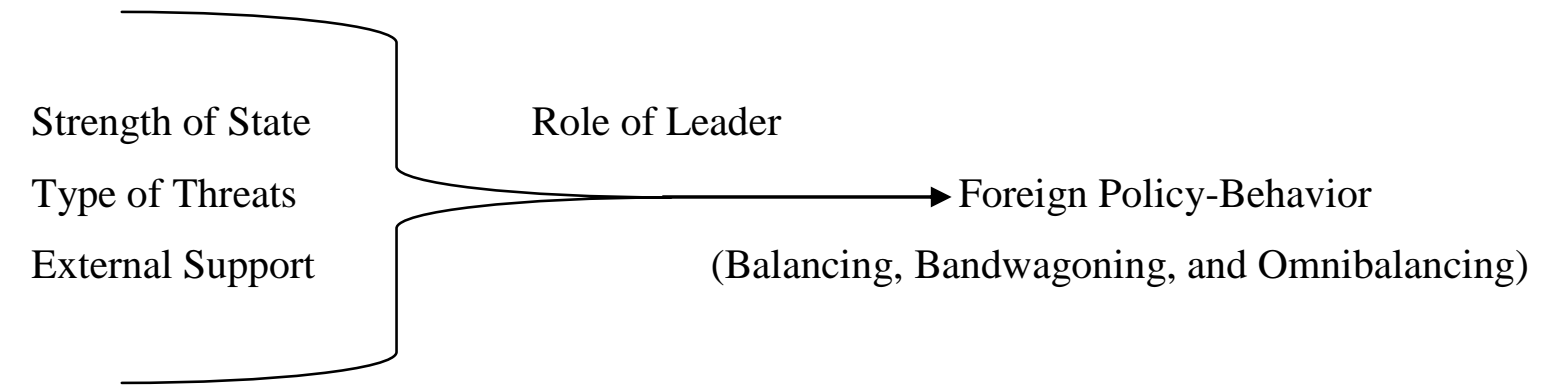


There are three objectives of this dissertation. The primary objective is to reveal the sources of foreign policy-behavior of the Caucasus states and their relationships with Russia that established theories of international relations tend to overlook or neglect. The secondary objective is to pay attention to effects of state strength and the role of external powers on foreign policy-behavior of new states in the post-Soviet environment. The final and third objective is to understand the influence of leaders' orientations and type of threats on foreign policy-behavior. The major schools of international relations lack a coherent theoretical framework for understanding how and under what conditions these variables affect the foreign policies of the post-Soviet states. It is clearly impossible to understand fundamental patterns of post-Cold War world politics without understanding these three objectives in general.

A closer analysis of Armenian-Russian, Azerbaijani-Russian and GeorgianRussian relations in the context of international relations theory allows us to approach a broader question: why do new states do what they do? Theoretical constructs serve the additional purpose of initiating a more systematic analysis of relationships between Russia and post-Soviet states in general. Toward this end, region-wide dependence on Moscow and the weaknesses of the new post-Soviet states relative to Russia make Armenian-Russian, Azerbaijani-Russian and Georgian-Russian relations a good starting point for a comparative argument.

In sum, the primary focus of this dissertation is the foreign policy behaviors of the Caucasian states. A secondary focus is to explain why the post-Soviet states have different foreign policies. 


\section{Definitions}

Hollis and Smith suggest that there are not one but two stories to be told about any social phenomenon; one told from the inside and the other told from the outside. ${ }^{1}$ The inside story seeks to understand social phenomena; for example, why do leaders implement certain types of foreign policies? This insider's story investigates intent, meaning, perception and justification. By contrast, the outside story seeks to explain social phenomena; certain laws exist so that a given set of circumstances will result in a given set of outcomes, creating positivistic "if...then..." hypotheses. Thus, foreign policy behavior is a product of identifiable political, strategic and other forces. Therefore, the outsider's story investigates cause and effect.

In this dissertation, I shall attempt to explain both stories: i.e., foreign policymaking and foreign policy-behavior of new states. Therefore, this dissertation will focus on the analysis of foreign policy. To begin such an inquiry, one needs to ask the basic questions: What is foreign policy? Who makes the foreign policy of new states? What are the main variables in trying to understand and explain the foreign policy behaviors of new states? What are the relationships between strength of state and foreign policymaking? What kinds of foreign policy alternatives do states have?

\section{Foreign Policy}

To explain a foreign policy phenomenon is to contain it within a cause and effect cycle or, at the very least, to locate it within a pattern of a causal-effect system. First we should state what we mean by foreign policy.

\footnotetext{
${ }^{1}$ Martin Hollis and Steve Smith, Explaining and Understanding of International Relations (Oxford: Claredon Press, 1991).
} 
There are numerous definitions of foreign policy. ${ }^{2}$ According to William Wallace, "foreign policy is that area of politics which bridges the all-important boundary between the nation-state and its international environment."3 Joseph Frankel's definition seems broader: "foreign policy consists of decisions and actions which involve to some appreciable extent relations between one state and another." ${ }^{, 4}$ Wilkenfeld and his coauthors define foreign policy as consisting of "those official actions (and reactions) which sovereign states initiate (or receive and subsequently react to) for the purpose of altering or creating a condition (or problem) outside their territorial-sovereign boundaries." ${ }^{, 5}$ So foreign policy can be defined as governmental activities which are concerned and related with states and other international actors (international organizations, multinational and foreign corporations) in the international system. In short, in a sense foreign policy is the extension of the state's inner self into the outside world. Foreign and domestic policies are, therefore, inseparable and constitute only different phases of one overall program.

Foreign policy-making is hence not an isolated phenomenon from other governmental activities. Indeed, it can only be understood within the context of other governmental activities: the objectives a government has chosen, leaders' perception, the economic situation, domestic political conditions, psychological attitudes, etc.

\footnotetext{
${ }^{2}$ One of the latest works on foreign policy is Christopher Hill's The Changing Politics of Foreign Policy (London: Palgrave Macmillan, 2003). He defines foreign policy briefly as "the sum of official external relations conducted by an independent actor (usually a state) in international relations," p. 3.

${ }^{3}$ William Wallace, Foreign Policy and the Political Process, (London: Macmillan, 1971), p. 7.

${ }^{4}$ Joseph Frankel, The Making of Foreign Policy; An Analysis of Decision-Making, (Oxford; Oxford University Press, 1963), p 1.

${ }^{5}$ Jonathan Wilkenfeld et al, Foreign Policy Behavior: The Interstate Behavior Analysis Model, (Beverly Hills: Sage Publications, 1980), p. 110.
} 
The explanation of foreign policy-behavior is dependent upon the analytic determination of variables which are assumed to be causally effective in producing certain foreign policy outcomes. There are a variety of methods and perspectives from which to approach the analysis of foreign policy-behavior. ${ }^{6}$ Foreign policy-behavior can only be sufficiently explained as the product of an interaction between the state's domestic needs and its role and position within the international and regional system in which it operates. Thus, while state formation determines what a state wishes to do, it is the system level that determines what it can do. Each state's behavior is, therefore, differentially shaped by its position within international and regional systemic settings, particularly by varying levels of dependency on the international and regional system and by varying the global and regional powers' involvement in the region and their relations with the state. Over the long run, a new state's position can strengthen or switch its foreign policies from the original direction. In addition to those, a new state's position is also a product of its level of state formation and position in its systemic environments. ${ }^{7}$

\section{Independent Variables}

\section{State Strength}

Thomas J. Vogly and Alison Bailin in their work, International Politics \& State

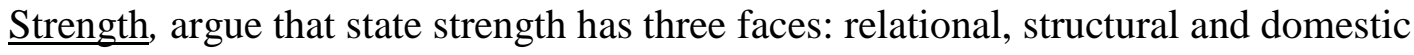

\footnotetext{
${ }^{6}$ See Charles F. Hermann, Charles W. Kegley, and James N. Rosenau, eds., New Directions in the Study of Foreign Policy (Boston: Allen \& Unwin, 1987; Walter Carlsnaes, "Foreign Policy", in Handbook of International Relations, Walter Carlsnaes, Thomas Risse, and Beth A. Simmons, eds., (London; Sage Publications, 2002).

${ }^{7}$ Raymond Hinnebusch, The International Politics of the Middle East, (Manchester: Manchester University Press, 2003), p. 8.
} 
strength. ${ }^{8}$ They extended Susan Strange's categorization of state strength, which proposes that state strength has a multidimensional nature; i.e., relational strength and structural strength. ${ }^{9}$ Relational strength is based on the capability of a state to influence other states' or actors' behaviors. However, on the other hand, structural strength is the capability to “create essential rules, norms, and modes of operation for various dimensions of international system." ${ }^{10}$ Moreover, Volgy and Bailin include domestic strength as a third feature of state strength. Domestic strength has three features: availability of substantial economic resources, controlling domestic needs and priorities, and politically a strong government. $^{11}$

To explain the role of state strength to new states' foreign policy, I will combine relational and structural strength within the external dimension of state strength. It is clear that for states strength has both an internal and external dimension.

The internal dimension of state strength depends on the capacity and leadership of the state taken together. In this context, the internal dimension of state strength is the set of shared norms, ideas and institutions that create and sustain an atmosphere and stable institutions to pursue common goals and interests of the leadership of the state. The external dimension of state strength is the self-placement of the state relative to other states and its interests and aspirations in the international and regional system, and how

\footnotetext{
${ }^{8}$ Thomas J. Volgy and Alison Bailin, International Politics and State Strength (Boulder: Lynne Rienner, 2003), pp. 40-42.

${ }^{9}$ Volgy and Bailin, pp. 40-41.

${ }^{10}$ Volgy and Bailin, p. 41.

${ }^{11}$ Volgy and Bailin, p. 42.
} 
other states place the state in the international arena. Thus, state strength represents a starting point for foreign policy-making.

Which states are weak states? Many scholars have used the terms "weak" states differently. ${ }^{12}$ Some scholars describe and employ the notion of 'state weakness' or 'weak state' according to a 'state-in-society approach'. According to this approach, the state is part of society, where people as groups and individuals struggle to obtain control over state structure and institutions. ${ }^{13}$ Joel Migdal, in his book, Strong Societies and Weak States: State-Society Relations and State Capabilities in the Third World, points out that competition among societal groups shapes state policies and behaviors. In this view, states as organizations provide legitimacy and power to certain groups and/or individuals. Therefore, state strength can be defined as the ability of a state to maintain political and

\footnotetext{
${ }^{12}$ Some time scholars use "small states," "small nations," "small powers" instead of "weak states." Barry Buzan emphasizes in his book, People, States \& Fear: An Agenda for International Security Studies in the Post-Cold War Era, $2^{\text {nd }}$ ed. (New York: Harvester Wheatsheaf, 1991), difference between "weak or strong states." Weak or strong states will refer to the degree of socio-political cohesion; weak or strong powers will refer to the distinction between states in respect of their military and economic capability in relations to each other. See, Jeanne A. K. Hey, ed., Small States in World Politics: Explaining Foreign Policy Behavior (Boulder: Lynne Rienner, 2003); Svante E. Cornell, Small Nations and Great Powers: A Study of Ethnopolitical Conflict in the Caucasus, (Surrey: Curzon, 2001); Milan Jazbec, The Diplomacies of New Small States: The Case of Slovenia with Some Comparison from the Baltics (Aldershot: Ashgate, 2001); Werner Bauwens, Armand Clesse and Olav F. Knudsen, eds., Small States and the Security Challenge in the New Europe (London: Brassey's, 1996); Charles W. Walldorf, Small States in International Affairs: Russian Relations with Azerbaijan and Tajikistan 1993-1994 (Unpublished Master Thesis at the University of Virginia, 1996); Miriam F. Elman, "The Foreign Policies of Small States: Challenging Neorealism in Its Own Backyard,” British Journal of Political Science, 1995, 25, pp. 171-217.; Suzanne Goldenberg, Pride of Small Nations: The Caucasus and Post-Soviet Disorder, (London: Zed Books, 1994); Peter J. Katzenstein, Small States in World Markets: Industrial Policy in Europe (Ithaca: Cornell University Press, 1985); Omer De Raeymaeker et al., Small Powers in Alignment (Leuven: Leuven University Press, 1974); August Schou and Arne Olav Brundtland, eds., Small States in International Relations (New York: John Wiley \& Sons, Inc., 1970); Robert L. Rothstein, Alliances and Small Powers (New York: Columbia University Press, 1968), Annette B. Fox, The Power of Small States: Diplomacy in World War II (Chicago: The University of Chicago Press, 1959).

${ }^{13}$ A. G. Hopkins, "Quasi-states, Weak States and the Partition of Africa," Review of International Studies (2000), 26, pp. 311-320; Peter Dauvergne, ed., Weak and Strong States in Asia-Pacific Societies (Canberra: Allen \& Unwin, 1998); Joel S. Migdal, Strong Societies and Weak States: State-Society Relations and State Capabilities in the Third World (Princeton: Princeton University Press, 1988); Michael Handel, Weak States in the International System (London: Frank Cass, 1981), Marshall R. Singer, Weak States in a World of Powers: The Dynamic of International Relationships (New York: The Free Press, 1972).
} 
social order, secure control over society within the rule of law, make effective policies to preserve stability, and retain legitimacy of power and status internally and externally. Peter Dauvergne distinguishes the strength of states according to states' interaction with different political and social groups. According to Dauvergne, state strength depends not only on a state's political system, its military and police, bureaucracy, history, economic structure, and cultural traditions, but also on the relative position of the state in both regional and international systems. These features shape the extent of state control over society and the extent to which political and social groups increase or decrease state strength. ${ }^{14}$

In this scheme, there are thus two types of state: strong and weak. A clear-cut definition of a weak state is hard to reach, because the strength of a state is a relative concept. I shall nevertheless attempt to define a weak state because it will indicate crucial tenets of the key foreign policy-behavior of the Caucasus states. A weak state is a state which recognizes that it cannot obtain security primarily by use of its own capabilities because it is a state whose population has competing national and ethnic loyalties, no real experience of statehood (lack of past state legacy or legacy of past or minimum experience of statehood), no real strong and organized state infrastructure and institutions and the absence of a stable process of peaceful political succession; such a state relies fundamentally on the political, economical and military aid of other states and international organizations. Thus, the framework of this dissertation employs a stateoriented approach in linking state strength to domestic politics and ultimately to foreign policy.

14 Peter Dauvergne, "Weak State, Strong States: A State-in-Society Perspective," in Weak and Strong States in Asia-Pacific Societies, Peter Dauvergne, ed., (Canberra: Allen \& Unwin, 1998), p. 2. 
On the other hand, strong states enjoy autonomy and capacity. An autonomous state can formulate and pursue goals that "are simply reflective of the demands or interests of social groups, classes, or society." ${ }^{\prime 15}$ Capacity is a state's ability to utilize and make use of citizen's resources as it wishes. ${ }^{16}$ In a strong state, powerful bureaucracies ensure citizen's security and well-being and command their loyalties. In a weak state, government bureaucracies, if they exist, are mainly controlled by or responsive to only a segment of society, ruling elite. Its administrative capacity is poorly developed, and the government can be manipulated by outsiders. ${ }^{17}$

\section{Type of Threats}

The difference between weak and strong states is essential to any analysis of threat. Because of differences of strength, the particular nature of threat differs considerably from a weak state to a strong state. All states are sensitive and vulnerable to military and environmental threats. ${ }^{18}$ Practically all are open to economic threats and many also face significant domestic threats. In other words, different kinds of state appear vulnerable to different kinds of threat. The different capacity of states makes threat a problem in many dimensions rather than just a matter of military threats. ${ }^{19}$

\footnotetext{
${ }^{15}$ Theda Skopcol, "Bringing the State Back in: Strategies of Analysis in Current Research," in Bringing the State Back in, Peter B. Evans, Dietrich Rueschemeyer, and Theda Skopcol, eds., (Cambridge: Cambridge University Press, 1985), p. 9.

${ }^{16}$ Skopcol, 1985, p. 17.

${ }^{17}$ Richard W. Mansbach, $3^{\text {rd }}$ edition, The Global Puzzle: Issues and Actors in World Politics (Boston: Houghton Mifflin Company, 2000), p. 72.

${ }^{18}$ See, for more information on sensibility and vulnerability, Robert O. Keohane and Joseph S. Nye, Power and Interdependence, (Boston: Little Brown, 1977).

${ }^{19}$ Buzan, 1991, p. 97.
} 
There are two kinds of threat: internal and external threats. After the end of the Cold War, the intrastate conflicts of new states have become a focus and concern of world politics. ${ }^{20}$ Barry Buzan classifies internal threat into four general categories: "those arising from direct administrative or political action by the state against individuals or groups; those arising from struggles over the control of the state machinery; those arising from the state's external security policies." ${ }^{21}$ In addition, intrastate conflicts may be caused by the internal competition for power and resources, as well as ethnic-separatist conflicts.

The other side of the coin of internal threat for the weak state concerns threats arising from political disorder and the struggle for control over the state's institutions and political power. These conflicts are typical features for those states that have not completed the state-building process. Quite often, new states have very weak state institutions and they cannot properly provide security for the leadership as well as the people. Consequently, the leaders of weak states look elsewhere because internal conflicts can create internal threats to the leadership. This internal threat can also be seen as a primary and urgent threat, one that is often more dangerous than external threats as such.

An external threat means that states or a coalition of states pose a threat to another state's sovereignty and independency. According to Stephen Walt, external threat can be

\footnotetext{
${ }^{20}$ Ivan Ivekovic, Ethnic and Regional Conflicts in Yugoslavia and Transcaucasia: A Political Economy of Contemporary Ethnonational Mobilization (Ravenna: Longo Editore, 2000); Thomas Ambrosio, Irredentism: Ethnic Conflict and International Politics (Westport: Praeger, 2001); Stephen M. Saideman, The Ties that Divide: Ethnic Politics, Foreign Policy, and International Politics (New York: Columbia University Press, 2001); and Stuart J. Kaufman, Modern Hatreds: The Symbolic of Ethnic War (Ithaca: Cornell University Press, 2001).

${ }^{21}$ Buzan, 1991, p. 44.
} 
determined by the intentions of other states coupled with their collective power, geographic proximity, and offensive capabilities of other states. ${ }^{22}$ Thus external threat could be against the state structure or against a population.

\section{External Support}

The newly established weak states have achieved, in some instances, a kind of negative security based on their own weaknesses. Since they lack a strong state structure, possess a weak security and economic base and only an undeveloped governmental framework, new independent states also lack the opportunity to develop their own foreign policy. For this reason, the foreign policy-behavior of weak states basically aims at resisting pressure from the great and/or regional powers, at defending their territorial integrity and independence, at insuring the continuation of its sovereignty, and at providing security for their leadership. In this regard, a weak state is a state on the defensive. In other words, a weak state is hungry for security.

Weak states can be threatened by regional powers and/or other states. Thus, weak states have to look to external support for assistance to deter the threat. Sometimes, weak states are the accidental beneficiaries of a major structural change in the international system. Uzbekistan is a good example. Before the September 11, 2001 incidents in New York, Washington, D.C., and Pennsylvania, the United States was critical about Islam Karimov's government and recognized Uzbekistan as under the Russian sphere of influence. After September 11, however, Karimov's government became one of the closest allies of the United States in Central Asia because of Uzbekistan's geopolitical position in the region. This indicates that a shift in policy of the global power, which is

\footnotetext{
${ }^{22}$ Stephen M. Walt, The Origins of Alliances (Ithaca: Cornell University Press, 1987).
} 
not directly related to Uzbekistan, also changed Uzbekistan's position in the international system. Uzbekistan shifted its foreign policy from bandwagoning to the former imperial center, Russia, to being allied with the global power, i.e. the United States.

In conclusion, external powers perform a crucial role in developing a supportive atmosphere for new states' foreign policy-making and establishing the conditions that lead not only to lowering the cost of changing foreign policy for new states but also redefining relations between new states and the former imperial power. ${ }^{23}$ Through their involvement in the region, third parties can change weak states perceptions of the costs, risks, and benefits of foreign policy choices.

\section{Intervening Variables}

\section{Role of Leadership}

Stephen D. Krasner defines a state as composed of "central decision making institutions and roles" in the political system. ${ }^{24}$ How these institutions are working and why they have played certain roles can be framed by three components: who governs, the interests and beliefs of those who govern and the constraints under which they operate. Therefore the underlying point is that personality factors, a leader's style, belief system, perceptions, and value, clearly shape foreign policy decision-making behavior. In other words, the main personality factor is the ruling elite's orientation to international relations, that is, the leadership's core beliefs about their state's position in the international system.

\footnotetext{
${ }^{23}$ Jacob Bercovitch, Social Conflict and Third Parties: Strategies of Conflict Resolution (Boulder: Westview, 1994), p. 26.

${ }^{24}$ Stephen D. Krasner, Defending the National Interest: Raw Materials Investments and U.S. Foreign Policy (Princeton: Princeton University Press, 1978), pp. 12-13.
} 
When the core beliefs and interests of a state's leadership correspond to those of key political elites in a country, then the interests and beliefs of the leader become the state interests of the country but not necessary the 'national interest'. In other words, foreign policy becomes the product of leadership that views the state's interest through its own personal belief systems and preferences as well as from its own interests. Thus, an individual leader's beliefs and interests turn into an important variable to explain a state's foreign policy.

Goldstein and Keohane bring out that there are three types of beliefs: worldview, principled beliefs, and causal beliefs. World views are the ideas that define the universe of possibilities for action. In a worldview, human beings are assumed to be active agents in the construction of their own destinies. Principled beliefs are normative ideas for distinguishing right from wrong and just from unjust. Causal beliefs provide guides for individuals on how to achieve their objectives. ${ }^{25}$

The personality of leaders is, thus, especially important in weak new states. In a weak state, to understand the foreign policy of the country we need to inquire how

\footnotetext{
${ }^{25}$ Another work done on personality of leadership is by James D. Barber. Barber defines personality of leaders and explores its implication for policy in terms of three elements. The first is worldview, which refers to individual's politically relevant beliefs. The second element is style, which refers to an individual's habitual ways of responding to political opportunities. The third and last element is the character, which is the way individual orient himself and herself; James D. Barber, Presidential Character: Predicting Performance in the White House, $4^{\text {th }}$ ed. (Englewood Cliffs: Prentice Hall, 1992). See also Judith Goldstein and Robert O. Keohane, "Ideas and Foreign Policy: An Analytical Framework," in Ideas and Foreign Policy: Beliefs, Institutions, and Political Change, Judith Goldstein and Robert O. Keohane, eds., (Ithaca: Cornell University Press, 1993); Margaret G. Hermann, Joe F. Hagan, "International Decision Making: Leadership Matters," Foreign Policy, 1998, 110, pp. 124-137; Paul A. Anderson, "What Do Decision Makers Do When They Make a Foreign Policy Decision?" pp. 285-308, in Charles F. Hermann, Charles W. Kegley, and James N. Rosenau, eds., New Directions in the Study of Foreign Policy (Boston: Allen \& Unwin, 1987); Margaret G. Hermann, "Effects of Personal Characteristics of Political Leaders on Foreign Policy," in Why Nations Acts: Theoretical Perspectives for Comparative Foreign Policy Studies, Maurice A. East, Stephen A. Salmore, Charles F. Hermann, eds., (Beverly Hills: Sage Publications, 1978); Deborah W. Larson, Anatomy of Mistrust: U.S.- Soviet Relations During the Cold War (Ithaca: Cornell University Press, 1997); Stanley A. Renshon and Deborah W. Larson, eds., Good Judgment in Foreign Policy: Theory and Application (Lanham; Rowman \& Littlefield, 2003).
} 
leaders control political power, what kind of role other political institutions play, and how the leader's power is restrained by the other political institutions and where leaders exercise decisive influence over the conduct of foreign policy. Especially during the state-building process of new states, the leaders' personal interests and strategies, and the relationship between such interests and strategies and the international environment in which they act shape states' foreign policies and state's 'national interest'. Even if leaders are the most significant agents for new states their perceptions are shaped by their psychological, social and cultural environments. The way in which leaders have sought to legitimate themselves as rulers is also part of the process by which the state itself is constituted and represented in the international arena. Therefore, leaders, especially in newly independent states, become the main authority to make foreign policy choices. Their political experiences, for example, may have taught them that certain interests, beliefs and ways of handling issues are important for foreign policy-making. ${ }^{26}$ Thus, characteristics of leaders are important for new weak states because foreign policymaking in a weak state is normally a personalized process. Leaders are assisted by a few political protégés and a small and low-powered, inexperienced, and uncoordinated bureaucracy. Neither parliament, nor political parties, nor interest groups, nor public opinion tend to exercise much influence on the leader. ${ }^{27}$ The issue thus is not whether leadership matters, but rather how much it does matter, and under what conditions.

\footnotetext{
${ }^{26}$ Juliet Kaarbo, Jeffrey S. Lantis, and Ryan K. Beasley, "The Analyses of Foreign Policy in Comparative Perspective," in Foreign Policy in Comparative Perspective: Domestic and International Influences on State Behavior, eds. Ryan K. Beasley et al (Washington, D. C.: Congressional Quarterly Inc., 2001), pp. 18-19.

${ }^{27}$ Peter J. Boyce, Foreign Affairs for New States: Some Questions of Credentials (New York: St. Martin's Press, 1978), p. 55.
} 


\section{Dependent Variables}

\section{Balance of Power/Threat}

The balance of power is the best known theory of alliances. ${ }^{28}$ Basically, balance of power theory examines the strategic incentives for states to come to one another's aid against a state that seeks to change the status quo in either a region or in the world. Balancing is, thus, a logical consequence of seeking the international status quo and a state's own security. As Kenneth N. Waltz argues, "secondary states, if they are free to choose, gather to the weaker side, for it is the stronger side that threatens them." ${ }^{29}$ Waltz also writes that the "power of the strong may deter the weak from asserting their claims, not because the weak recognize a kind of rightfulness of rule on the part of the strong, but simply because it is not sensible to tangle with them.",30

Stephen M. Walt introduced an important amendment to balance of power logic with his claim, based on his study of Middle East alignment strategies through 19551979, that states do not balance power per se but rather balance threats. The balance of threat occurs when 'the states join alliances to protect themselves from states or coalitions whose superior resources could pose a threat., ${ }^{31}$ Therefore, balancing threat is

\footnotetext{
${ }^{28}$ See more resources about balance of power. Kenneth N. Waltz, Theory of International Politics (Reading: Addison-Wesley Pub. Co., 1979); Stephen M. Walt, The Origins of Alliances (Ithaca: Cornell University Press, 1987); Glenn Synder, Alliance Politics (Ithaca: Cornell University Press, 1997); Stephen M. Walt "Testing Theories of Alliance Formation: The Case of Southwest Asia," International Organization 1988, 43, pp. 275-316; John A. Vasquez, and Colin Elman, eds. 2003, Realism and the Balancing of Power: A New Debate (Upper Saddle River: Prentice Hall, 2003); Randall L. Schweller, "Bandwagoning for Profit: Bringing the Revisionist State Back In," International Security, 1994, 19, pp. 72-107; John J. Mearsheimer, The Tragedy of Great Power Politics (New York: W. W. Norton and Company, 2001); Edward V. Gulick, Europe's Classical Balance of Power (Ithaca: Cornell University Press, 1955).

${ }^{29}$ Waltz, 1979, p. 126.

${ }^{30}$ Waltz, 1979, p. 113.

${ }^{31}$ Walt, 1987, p. 265.
} 
allying with others against a dominant threat. States are risking their survival if they do not respond to a rising power, so they join with those who cannot dominate them; this also gives the alliance member greater influence within the alliance itself.

\section{Bandwagoning}

Bandwagoning is allying with the threatening power. A state may instead of bandwagoning with a threatening state join it in the hope either of deflecting the threat to another state or satisfying its demands. The assumption here is that power attracts allies, so that a smaller state can preserve its independence or be on the winning side in the case of conflict. Walt, in his attempt to understand when states bandwagon, concluded that the plausibility for bandwagoning will be high if the state is weak, if there are no available allies and if there is conflict. ${ }^{32}$ Randall L. Schweller sees this type of bandwagoning, siding with stronger and even more threatening powers for protection, as 'bandwagoning for profit. ${ }^{33}$ John J. Mearsheimer, providing another argument regarding bandwagoning for profit, claims that states may do bandwagoning but 'the distribution of power', will shift further against bandwagoner and in the stronger state's favor." 34 In other words, according to Mearshiemer, bandwagoning is a strategy of weak states; however, the weak states will not profit from bandwagoning in the end.

\section{Omnibalancing}

Omnibalancing is based on containing both the needs of leaders to balance against any immediate threat (internal and/or external) and the need to appease secondary threats

\footnotetext{
${ }^{32}$ Walt, 1987 , pp. $28-32$.

${ }^{33}$ Schweller, 1994, pp. 72-107.

${ }^{34}$ Mearsheimer, 2001, pp. 162-163.
} 
in order to stay in power. According to omnibalancing views, the "most powerful determinant of Third World alignment behavior is the rational calculation of Third World leaders as to which outside power is most likely to do whatever necessary to keep them in power. ${ }^{35}$ In other words, internal and external threats to the state leadership directly affect these leaders' right or ability to rule; therefore, these leaders are addressing their self-interests, not necessarily their national interests.

Stephen R. David states that foreign policy decisions are a product of choice, for example, leaders' considerations of whether the main threat to leadership lies in domestic threats or external threats: thus, if the threat to the ruling elite is stronger at home they may reach out to external powers to get the protection and resources needed to cope with the domestic opposition and greater internal threat. ${ }^{36}$

Thus, omnibalancing make possible the understanding of weak state foreign policy actions because leaders of weak states have the vital security threats, which they must take into account first and urgently. Therefore, the omnibalancing approach calls for the evaluation of external and internal threats, with respect to the leader's political survival, not the state's survival.

\section{Research Questions}

It appears that the post-Cold War era promotes different kinds of relations between new states and former imperial centers than did those of the Cold War. During the Cold War era, the international system was defined as a bipolar system. Foreign

\footnotetext{
${ }^{35}$ See detailed discussion on p. 83. Steven R. David, Choosing Sides: Alignment and Realignment in the Third World (Baltimore: The Johns Hopkins University Press, 1991), p. 6; and Steven R. David,

“Explaining Third World Alignment,” World Politics, January 1991, 43, 2, pp. 233-256.

${ }^{36}$ Steven R. David, Choosing Sides, 1991, pp. 12-13.
} 
policy behaviors of states were defined according to their relationship to one of the two pillars of the cold war: international order and the ideology of the state in the international system. However, with the end of the Cold War, the bipolar system and ideological competition vanished.

The new trend in the post-Cold War environment reflects the degree of uncertainty regarding the type of international system emerging. Uncertainty about the characteristics of the international system also affects the directions of the foreign policies of states in general. In particular, the end of the Cold War, the collapse of the Soviet Union and at the same time the birth of 15 new post-Soviet states provide us with a unique opportunity to observe interstate relations between a former imperial power and new post-imperial (as well as post-communist and post-cold war) states. Thus, the end of the Cold War's bipolarity system has raised essential questions about the nature of relations between states and perceptions of major threats to the states. Therefore, one of the main questions concerns how such new states organize and implement their foreign policies.

The most common explanation of the foreign policy of states depends on two features: the theoretical concept of power and the preferences of stronger states. ${ }^{37}$ This study, however, has alternative explanations of the foreign policy of the new weak states. In this dissertation I shall suggest that several of the assumptions central to rational actor and realist approaches, which are based on the concept and distribution of power, defined in terms of national interest do not appear sufficient to explain adequately the foreign policies of new states. The main rational schools of international relations are focused on

\footnotetext{
${ }^{37}$ Bruce E. Moon, "Consensus or Compliance? Foreign-Policy Change and External Dependence," International Organization, Spring 1985, vol. 39, no. 2, p. 297.
} 
the major powers and employ external factors to explain the foreign policy orientation of the states. They ignore certain (often key) domestic and human factors. For that reason I shall combine domestic factors with external factors in order to explain the foreign policies of new states. I suggest that the state-building process of new states, the type of threats, and the political orientation of the leadership as well as external support are key independent variables to explain the foreign policy actions of new weak states.

The main research question of the dissertation is, what is the relationship between the structural characteristics of a state and its foreign policy actions? Recent research on this question has not sufficiently worked toward identifying reliable patterns of weak states' foreign policy behavior. Most scholars agree that economic and security dependence influences foreign policy actions in some manner, but disagree on the nature and extent of that influence. ${ }^{38}$ The theoretical and empirical works treating weak states' foreign policy action has generated a murky and often contradictory picture of how weak states develop foreign policies in the international arena. Numerous theories applied to a variety of states deliver very different explanations of the process through which weak states make foreign policy. ${ }^{39}$

\footnotetext{
${ }^{38}$ See Richard N. Lebow, "Small States and Big Alliances," American Political Science Review, September 1997, vol. 91, no. 3, pp. 705-709; Rajan Menon and Hendrik Spruyt, "The Limits of Neorealism: Understanding Security in Central Asia," Review of International Studies, 1999, vol. 25, pp.87-105; Robert I. Rotberg, "The New Nature of Nation State Failure," The Washington Quarterly, Summer 2002, vol. 25,no. 3, pp. 85-96; Nikolas Zahariadis, "Nationalism and Small State Foreign Policy: The Greek Response to the Macedonian Issue," Political Science Quarterly, Autumn 1994, vol. 109,no. 4, pp. 647-667.

${ }^{39}$ See James D. Fearon and David D. Laitin, "Neotrusteeship and the Problem of Weak States," International Security, Spring 2004, vol. 24, no. 4, pp. 5-43; Michael C. Desch, "War and Strong States, Peace and Weak States?" International Organization, Spring 1996, vol. 50, no. 2, pp. 237-268; Miriam F. Elman, "The Foreign Policies of Small States: Challenging Neorealism in Its Own Backyard," British Journal of Political Science, 1995, vol. 25, pp. 171-217; Bruce E. Moon, " The Foreign Policy of the Dependent State," International Studies Quarterly, September 1983, vol. 27, no. 3, pp. 315-340; Francis Fukuyama, "The Imperative of State-Building," Journal of Democracy, April 2004, vol. 15, no. 2, pp. 17 31.
} 
The second question is related to the foreign policies of post-Soviet states in the Caucasus. The foreign policies of post-Soviet states have defined the boundaries of several regions of the post-Cold War world, as some post-Soviet governments have sought to define their states as Western and European, others as Eurasian. Therefore, during the first decade of their independence, post-Soviet states' foreign policies were surprisingly dissimilar in terms of basic perspectives on their respective relations between the Russian Federation as an ex-imperial center and newly independent post-Soviet states. It is clear that, while all post-Soviet states have strong economic, security and political bonds with Russia, some post-Soviet states have cooperated closely with Russia during the 1990s (for example, Armenia, Belarus, Kazakhstan and Kyrgyzstan), while other did not (the Baltic states, Azerbaijan and Georgia, to a certain extent). Why did post-Soviet states, faced with similar external pressures and constraints from Russia, respond so differently to the new institutionalization of their relations with other states, especially with the Russian Federation? What factors led to a continued Russian dominance in parts of the former Soviet Union? Which contemporary international relations theories and/or foreign policy analysis, if any, explain the foreign policy actions of the post-Soviet republics?

Identifying the threats motivating the Caucasus states' foreign policy actions or alignments is vital for understanding the actions and positions of the post-Soviet states in international and regional system. Policy makers as well benefit from this knowledge since most conflict in the post-Cold War world has not been interstate but intrastate, that is, conflict within states and not between them. 
The main empirical purpose of this study is to contribute to an understanding of the Armenian-Russian, Azerbaijani-Russian and Georgian-Russian foreign relationships in the period since the collapse of Soviet Union. Thus, in the empirical part of this dissertation, I will respond to questions as to why Armenia, Azerbaijan and Georgia have developed different foreign policies towards the Russian Federation than other postSoviet states have, e.g., the Baltic states and the Central Asian states. ${ }^{40}$ In this dissertation I claim that one of the main reasons for the different foreign policies is that the postSoviet states have developed different degrees of state strength.

\section{Literature Review}

The field of international relations divided into two sections in the 1950s: international politics and foreign policy analysis. ${ }^{41}$ On the one hand, international politics concentrates on the international system and relations of major states as variables of international politics. On the other hand, foreign policy analysis focuses its attention on features of states as units in order to understand and explain their relations. Thus, one proceeds from top to the bottom, the other from the bottom to the top. In other words, one employs a deductive method, the other an inductive method to understanding and explaining relations among states.

\footnotetext{
${ }^{40}$ Alvin Rubinstein, Red Star on the Nile: The Soviet-Egyptian Influence Relationship since the June War (Princeton: Princeton University Press, 1977). Also see Adeed Dawisha and Karen Dawisha, eds., The Making of Foreign Policy in Russia and the New States of Eurasia (New York: M.E. Sharpe, 1995) and Andrei Tsygankov "Farewell to the Empire? National Identity and Varieties of State Foreign Economic Policies in the Former Soviet Region," in International Studies Association Annual Meeting (Washington, D.C., 1999).

${ }^{41}$ Kenneth N. Waltz, Man the State, and War (New York: Columbia University Press, 1959), and Richard C. Synder, H. W. Bruck, and Burton Sapin, eds. Foreign Policy Decision-Making: An Approach to the Study of International Politics, (New York: Free Press of Glencoe, 1962).
} 


\section{Theories of International Relations or Systemic Theories}

The intense debates on international relations theory have raged between the realist-liberal, the rationalist-constructivism camps for many years with no firm resolution in sight. Although there has been major success in identifying new aspects of international behavior, there has been little progress in developing a general model that is capable of accurately describing both historical patterns and events of international politics as well as serving as a pedictor for foreign policy behavior. Jeffrey Legro and Andrew Moravcsik rightly indicate that a grand unified theory that bridges the features of each of the major theories into a more accurate model of international relations is needed. $^{42}$

\section{Realism}

Realists agree that the study of international relations is primarily concerned with interstate relations in which states are the dominant actors and in which non-state actors, such as individuals, have little effect since they are under control of the state in which they live. ${ }^{43}$ Because of the anarchical and self-help nature of international politics, survival is the top concern of all states. Economic, ideological and moral/humanitarian interests follow security interests. States pursue these lower interests as long as doing so

\footnotetext{
${ }^{42}$ Jeffrey W. Legro and Andrew Moravcsik, “Is Anybody Still a Realist?” International Security, Fall 1999, 24,2 , pp. 5-55.

${ }^{43}$ See more realist literatures; Kenneth Waltz, "International Politics is not Foreign Policy," Security Studies, 1996, vol. 6, pp. 54-57; Robert Keohane, ed., Neorealism and its Critics (New York: Columbia University Press, 1986); Robert Gilpin, War and Change in World Politics (Cambridge: Cambridge University Press, 1981).
} 
does not violate security interests. Realist theories can be divided into four parts:

classical, neorealist (structural) ${ }^{44}$, defensive and offensive realist theories.

The classical realists view that, since states were created in an anarchic

environment, states seek survival. This claim continues to exist in neorealist, defensive and offensive realist schools. ${ }^{45}$ Thucydides, seen as the father of the realist school, stated that the strong do as they please and the weak suffer as they must. In other words, states seek to expand their power and thus their ability to defend themselves from the aggressive advances of their neighbors. ${ }^{46}$ States form alliances to protect themselves from immediate threats, but will abandon those alliances the moment a more advantageous opportunity arises.

Realism also sees that a state will not concern itself with the domestic activities of another state unless those activities pose a threat. Moreover, realists claim that all states play power politics but emphasize that some play power politics differently. In addition, realist also believes that states choose to compete because they have conflicting interests and preferences. To defend themselves and compete more effectively, states try to obtain more powers than their competitors.

\footnotetext{
${ }^{44}$ Kenneth Waltz's systematic effort to formulate a realist theory was based on the use of the concept of structure, which gave this form of realism the adjective "structural." Waltz used the concept of structure both to prop up the concept of system and to exclude all else from consideration.

${ }^{45}$ Hans Morgenthau, Politics Among Nations: The Struggle for Power and Peace (New York: McGrawHill, 1993); Kenneth N. Waltz, Man the State, and War (New York: Columbia University Press, 1959), and Theory of International Politics (Reading: Addison-Wesley Pub. Co., 1979); John J. Mearsheimer, "The False Promise of International Institutions," International Security, 1994/1995, vol. 19, no. 3, pp.5-49, and The Tragedy of Great Power Politics (New York: W. W. Norton \& Company, 2001); Randall L. Schweller, "Neorealism's Status-Quo Bias: What Security Dilemma?", Security Studies, 1996, vol. 5, no. 3, pp.90121; and Eric Labs, "Beyond Victory: Offensive Realism and the Expansion of War Aims," Security Studies, 1997, vol. 6, no. 4, p.12.

${ }^{46}$ David Carment and Patrick James, "Ethnic Conflict at the International Level: An Appraisal of Theories and Evidence," in Wars in the Midst of Peace: The International Politics of Ethnic Conflict, David Carment and Patrick James, eds., (Pittsburgh: University of Pittsburgh Press, 1997), pp. 253-254.
} 
Drawing on historical and other descriptive materials, classical realism was based on several assumptions:

1. States are far and away the most important actors.

2. The actions of states could be analyzed as if states were unitary, major actors.

3. States are rational actors. They choose the best available means to achieve their ends as unitary entities.

Classical realism seeks to offer a general theory. It treats both states and statesmen as rational. Without the rationality assumption, it would be impossible for any statesman to act on the "national interest," which, for realists, is what puts states, as billiard balls, into motion. The assumption of rationality considers the state to be a unified actor and that all states would respond in the same way under similar conditions; why often choose different foreign policy courses under similar conditions is, however, "under explained" by such realist approaches. ${ }^{47}$

John Mearsheimer, as a staunch realist, maintains that the world is an anarchic arena where states look for opportunities to take advantage of each other. This description of the political environment has led to the creation of five general realist assumptions about the international system ${ }^{48}$ :

a. The international system is anarchic;

b. States possess some level of offensive military power that can strike and, therefore, threaten, another state or states;

c. State can never be certain about the intentions of another state;

\footnotetext{
${ }^{47}$ Vendulka Kubalkova, "Foreign Policy, International Politics, and Constructivism," in Foreign Policy in a Constructed World, Vendelka Kubalkova, ed. (Armonk: M.E. Sharpe, 2001), p. 26.

${ }^{48}$ John Mearsheimer, “The False Promise of International Institutions," p. 10.
} 
d. All states have survival and the retention of sovereignty as primary national objectives;

e. States are rational actors.

These five assumptions generate three types of interactions between states. First, each state must run to help itself in order to guarantee its sovereignty and survival. The lack of a hierarchical system with a higher authority reduces the likelihood of deterrence or retaliatory actions against any aggressor state. That is each state must provide for its own security. Second, states maintain as a national goal the maximum relative power positions over other states. Finally, these two factors, according to Robert Jervis, when combined with the uncertainty of anarchical system, create a security dilemma. This is the situation in which as a nation attempts to increase its security, it may in turn unintentionally threaten neighboring nations which will lead to an increase in tensions and a net loss of security. ${ }^{49}$ In conclusion, realists postulate international anarchy, the absence of world government, as the foundation of their theory. According to these views, anarchy makes it impossible for states to fully trust one another, even if all states have good intentions.

However, for neorealism the structure of the international system is critical in determining how far states pursue their interests. The distribution of capabilities, or the power of a state relative to others within the system, is of central importance. The distribution of capabilities is itself held to be a defining feature of the structure. In its

\footnotetext{
${ }^{49}$ Original idea of 'security dilemma' was introduced by John Herz. Robert Jervis developed and reformulated the idea of security dilemma. See more on Security Dilemma, John Herz, Political Realism and Political Idealism: A Study in Theories and Realities (Chicago: University of Chicago Press, 1951); Robert L. Jervis, "Cooperation under the Security Dilemma," World Politics, January 1978, vol. 30, no. 2, pp. 167-214; and Charles L. Glaser, "The Security Dilemma Revisited," World Politics, October 1997, vol. 50, no. 1, pp. 171-201.
} 
pursuit of certain objectives, if a state finds its power balanced by an opposing state(s), the state is likely to refrain from acting. Some realists define the post-Cold War international system based on a hegemonic power, that is, the United States. ${ }^{50}$ They believe that hegemonic power can have a restraining power and provide stability. Defensive realists argue that states are basically motivated by security. For instance, Kenneth N. Waltz argues that states are defensive and thus balance, ${ }^{51}$ while offensive realists argue states seek mainly influence. For instance, John Mearsheimer contends that states are offensive and therefore "expand." 52

For realism to have analytical relevance in the foreign policy analysis, it must demonstrate that state power in the international system decisively shapes foreign policy. Realists believe that if foreign policy making is wholly unconstrained by the environment and thus power politics, then decision-making is a result of the free will of domestic politics. Realists also tend to support the view that there is no real difference between the

\footnotetext{
${ }^{50}$ G. John Ikenberry, After Victory: Institutions, Strategic Restraint, and the Rebuilding of Order After Major Wars (Princeton: Princeton University Press, 2001); William C. Wohlforth, "The Stability of Unipolar World," International Security, Summer 1999, vol. 24, no. 1, pp. 5-41; John J. Mearsheimer, "Back to Future: Instability in Europe After the Cold War," International Security, Summer 1990, vol. 15, no. 4, pp. 5-56, and The Tradegy of Great Power Politics (New York: W. W. Norton \& Company, 2001).

${ }^{51}$ The defensive realist argument is that states are motivated above all to worry about their survival. The argument is particularly associated with Kenneth Waltz (1979) but has been developed by other scholars as well. See Stephen M. Walt, The Origins of Alliances (Ithaca: Cornell University Press, 1987); Charles L. Glaser, "Realists as Optimists: Cooperation as Self-Help," International Security, 1994/1995, vol. 19, pp. 50-90; Stephen Van Evera, Causes of War: Power and the Roots of Conflict (Ithaca: Cornell University Press, 1999). The position is defensive because the prime goal of survival will cause states to worry about what they have and thus to be defensive or status quo states. It follows that states in principle will prefer balancing strategies in order to prevent the rise of dominating powers.

${ }^{52}$ Offensive realists assume that power politics motivate states to search for influence, and not survival, which in turn supports the argument that status quo and revisionist states, given their different motivations, pursue influence differently. See more Randall L. Schweller, "Neorealism's Status-Quo Bias: What Security Dilemma?" Security Studies, 1996, vol. 5, no. 3, pp. 90-121, Deadly Imbalances: Tripolarity and Hitler's Strategy of World Conquest (New York: Columbia University Press, 1998). Based on offensive realist's assumption that states seek influence, therefore, they examine how decision-makers respond to international power and seek to mobilize resources and support for new policies at home. In a foreign policy perspective, offensive realists therefore focus on how added or declining power shapes new policy ambitions.
} 
making of foreign policy in strong and weak states. They assume that states seek to maximize certain goals such as power, security, and the national interest, with the consequence that many important domestic influences on decision have simply been ignored. Most realists agree that the greater a state's power the more likely unit-level influences will determine its foreign policy. By contrasts, the weaker a state's power the more its behavior will reflect systemic-level constraints. ${ }^{53}$

\section{Liberalism}

Andrew Moravscik attempts to build a liberal theory of international relations by removing certain ideological and utopian elements often seen in liberal theory. ${ }^{54}$ For his approach, State-society relations are a key for liberal theory. Societal ideas, interest and institutions influence state behavior by shaping state preferences. State preferences equal social purposes underlying the strategic calculations of governments. State preferences matter most in International Relations, not distribution of capabilities as argued by realists. He also differentiates liberal theory from institutionalism and its model on information and institutions. Moravscik codifies three core liberal assumptions and develops three variants of liberal theory.

Moravscik's assumptions are:

\footnotetext{
${ }^{53}$ For review of this scholarly consensus, see Miriam F. Elman, "The Foreign Policies of Small States: Challenging Neorealism in Its Own Backyard," British Journal of Political Science, 1995, vol. 25, pp. 171217. On level analysis, generally see Kenneth N. Waltz, Man the State and War: A Theoretical Analysis (New York: Columbia University Press, 1959); Robert Jervis, Perception and Misperception in International Politics (Princeton: Princeton University Press, 1976), especially pp. 13-31.

${ }^{54}$ Andrew Moravcsik, "Taking Preferences Seriously: A Liberal Theory of International Politics," International Organization, Autumn 1997, vol. 51, no. 4, pp. 513-553.
} 
1. The primacy of societal actors as principal actors in International Relations, individuals and groups. Actors are rational in pursuit of material and ideal welfare.

2. The state is not an actor but a representative institution of some compartments of domestic politics upon which leaders define state preferences and act in International Relations.

3. The pattern of interdependent state preferences determines state behavior.

Liberal Theory Variations are:

1. Ideational Liberalism stresses the impact on state behavior of conflict and compatibility in social values or identities as related to public goods provisions.

2. Commercial Liberalism stresses the impact on state behavior of gains and losses to individuals and groups in society due to transnational economic activity.

3. Republican liberalism stresses the impact on state behavior of varying forms of domestic representations and the resulting incentives for social groups.

As a result, liberalism builds on two very different assumptions to explain state behavior. First, the liberals concentrate not on the boundaries of states, but on the lines of transactions among all actors (states, institutions, and human) in the international system. These transactions give rise to a complex international model that functions, not through coercion and threat, but interdependence. ${ }^{55}$ In this system, alliances can be formed not only between states, but also between individuals, non-governmental actors and even government departments; therefore, actors can surpass national boundaries.

\footnotetext{
${ }^{55}$ Robert O. Keohane and Joseph S. Nye, Power and Interdependence: World Transition $2^{\text {nd }}$ edition, (Boston: Little Brown, 1989)
} 
Second, given certain conditions, namely dyadic relations between democratic states, liberals predict that states can go beyond realist principles. Two states perceiving each other to be liberal-democratic will focus on principles in common to their domestic political democratic regimes in their relations with one another. Liberals have empirically demonstrated that democracies do not fight one another. John Owen notes clearly that "once liberals accept a foreign state as a liberal democracy, they adamantly oppose war against that state. ${ }^{, 56}$ In fact, if the interactions of democracies reduce zero-sum competition, states might by-pass certain material interests in pursuit of broader gains that cooperation may generate. Thus, democratic peace theory challenges neorealist claims that military capabilities and security interests will determine the presence or absence of aggressive foreign policy, and the idea that any dyad should always be prepared for their current allies to become future enemies. Moreover, it challenges the idea that threat perceptions are determined by the balance of power; rather, they are determined by ideology as reinforced by corresponding institutions.

Neoliberalism assumes that states will persist, though neoliberalism argues that states might be increasingly constrained by international institutions for choosing and implementing their foreign policies. ${ }^{57}$ Robert O. Keohane, as one of the leading neoliberalists, seeks to explain why cooperation among states in an anarchic international system takes place. Although not mentioned specifically, Keohane also assumes a highly interdependent relationship between states within the international environment. He

\footnotetext{
${ }^{56}$ John Owen, "How Liberalism Produces Democratic Peace," International Security, Fall 1994, vol. 19, pp. 5-49, p. 24.

${ }^{57}$ Robert O. Keohane and Joseph S. Nye, Power and Interdependence (Boston: Little Brown, 1977), pp. 2426.
} 
argues that cooperation can be institutionalized in a number of issue areas. He also seeks to explain under what conditions cooperation can occur and continue within international system. $^{58}$

Furthermore, Keohane sees international regimes as "intervening variables" between the anarchic international system and the actual behavior of states. Keohane argues that, examined closely, international politics resembles an iterated game where reputation and policy choices are affected by international regimes. International regimes reduce transaction costs and uncertainty within the anarchic international system.

Regimes also develop expectations of behavior that allow states to cooperate.

On the other hand, Thomas Risse-Kappen claims that domestic structures and coalition building-processes determine the effect on foreign policy formation. ${ }^{59}$ Using the United States, France, Germany and Japan, Risse-Kappen shows how “differences in political institutions, policy networks, and societal structures account for different foreign policy outcomes when the impact of the international environment is controlled for and public attitudes follow similar patterns across countries." ${ }^{60}$ Foreign policy outcomes are not the results of the "international status" of states, but of different domestic structures. Risse-Kappen asserts that the different domestic structures of countries have different impact that public opinion has on each country's foreign policy choices. From his empirical work on four different countries, Risse-Kappen draws three conclusions: (1) Mass public opinion mattered in all four cases, though to varying extents; (2) Indirect

\footnotetext{
${ }^{58}$ Robert O. Keohane, After Hegemony: Cooperation and Discord in the World Political Economy, (Princeton: Princeton University Press, 1984).

${ }^{59}$ Thomas Risse-Kappen, "Public Opinion, Domestic Structure, and Foreign Policy in Liberal Democracies," World Politics 1991, 43/44, pp. 479-512.

${ }^{60}$ Risse-Kappen, 1991, p. 480.
} 
effects of public opinion seem to be more important than direct effects and; (3) The domestic structure approach is useful. Therefore, he claims that "there is strong empirical evidence that domestic structures are the intervening variable between public opinion and foreign policy... The degree to which political institutions are centralized and the degree to which the state dominates the policy networks seem to be the determining factors."61

In conclusion, it is the assumption of rationality that they both share that makes neorealism and neoliberalism barely distinguishable. Indeed, many scholars agree that the only real difference between neorealists and neoliberals is that neoliberals think states seek absolute gain, and neorealists think states seek relative gains in their relations with other states. $^{62}$

\section{Constructivism}

Although the key debate in international relations theory has been between realism and liberalism, there is a third approach, constructivism, which has recently emerged as the main alternative to these two. Peter Katzenstein, Robert Keohane, and Stephen Krasner offer a summary of the development of IR theory in their article in International Organization that portrays the theoretical scene of IR as one dominated by theoretical debate between neorealism-neoliberalism, and rationalism-constructivism. Specifically, they argue that "constructivists have positioned themselves quite self-

\footnotetext{
${ }^{61}$ Risse-Kappen, 1991, p. 511.

${ }^{62}$ Robert O. Keohane, ed., Neorealism and Its Critics (New York: Columbia University Press, 1986); David A. Baldwin, ed., Neorealism and Neoliberalism: The Contemporary Debate (New York: Columbia University Press, 1993); Kenneth A. Oye, ed., Cooperation under Anarchy (Princeton: Princeton University Press, 1986).
} 
consciously between rationalist theoretical orientations, such as realism or liberalism, and postmodernist orientations". 63

The starting point of constructivism is that when agents act they utilize a social element that links people and society. Constructivism suggests that agents construct the world around them with the help of material resources and rules. Thus, constructivism has built up its theoretical premises on socially constructed premises as opposed to the rational premises. While constructivism has been developed primarily as a response to rationalist approaches, it is also playing a bridging role between rationalist and postmodernist theories, in the words of Emanuel Adler, that of "seizing the middle ground" between them. Adler suggests that constructivism shares some of the rationalist and postmodernist assumptions. ${ }^{64}$

Moreover, constructivism is concerned not with specifically international relations theories or level of analysis but with underlying conceptions of how the social and political world works. When Alexander Wendt, in his article, "Anarchy is What Make of It," attacks the core premise of neorealism and neoliberalism which is anarchy, he makes the argument that self-help and power politics do not necessarily arise from an anarchical world. He articulates that a realist will act based on the basis of a worst-case scenario. $^{65}$

\footnotetext{
${ }^{63}$ Peter J. Katzenstein, Robert O. Keohane, and Stephen D. Krasner, "International Organization and the Study of World Politics," International Organization, Autumn 1998, 52, 4, pp. 645-685, p. 678.

${ }^{64}$ Emmanuel Adler, "Seizing the Middle Ground: Constructivism in World Politics," in European Journal of International Relations, 1997, vol. 3, pp. 319-363.

${ }^{65}$ Alexander Wendt, “Anarchy is What Make of It,” International Organization, Spring 1992, vol. 46, pp. 391-425.
} 
Wendt accepts that states are more important actors than other actors such as multinational corporations and intergovernmental organizations but argues that state identities and interests can be collectively transformed within an anarchic context by many factors, such as individual, domestic, systemic, or transnational; therefore, states' identities and interests are important dependent variables. In addition, Wendt claims that self-help and power politics are institutions, not essential features of anarchy. Anarchy is what states make of it.

Furthermore, Wendt presumes that individuals create states and nations through shared norms and ideas of legitimacy. He mentions, however, that 'theories of international policies are distinguished from those that have as their object explaining the behavior of individual states, or "theories of foreign policy"... Like Waltz, I am interested in international policies, not foreign policy. ${ }^{66}$

On the other hand, Jeffrey Checkel indicates that constructivism is not a theory, but an approach to social inquiry based on three assumptions ${ }^{67}$ :

a. The environment in which agents/states/actors take action is social as well as material;

b. Identities constitute interests and actions;

c. Agents and structures are mutually constituted.

What is distinctive about constructivism as an approach to international politics? Constructivism shares two broad assumptions of neorealism and neoliberalism, i. e., a

\footnotetext{
${ }^{66}$ Alexander Wendt, Social Theory of International Politics, (Cambridge: Cambridge University Press, 1999), p. 11.

${ }^{67}$ Jeffrey Checkel takes up constructivism's neglect of domestic politics in "The Constructivist Turn in International Relations Theory," World Politics, January 1998, vol. 50, no. 2, pp. 324-348.
} 
commitment to both explanation and rationality. First, constructivism seeks primarily to explain the dynamics of international politics. Like rationalism, it makes causal claims, draws out their observable implications, and tests them against the empirical record. Second, constructivism endorses rationality assumptions. Like neorealism and neoliberalism it perceives international and domestic actors in rational search of interests within limits. Most constructivists view human rationality as a causal mechanism linking interests, constraints, and action.

However, what sets constructivism apart from rationalist approaches is its emphasis on the social dimension of international politics. Constructivism insists that international relations cannot be reduced to rational action and interaction within material and institutional constraints at the international and national levels.

Most constructivists believe that the split between foreign policy analysis and international politics is artificial; therefore, constructivism can provide the tools for bringing the two fields back together. The arrival of constructivism has coincided with what has been known as the "third debate" in International Relations, a debate over the positivist assumptions of science and their relevance to social phenomena. ${ }^{68}$

By defining both foreign policy and international politics as social, constructivists sees that both must start with people interacting in, and with, a world that is developed based on social and material interactions among the actors. This provides any social relations as constantly changing. ${ }^{69}$ In basic terms, constructivists see that states can perceive each other as enemies, rivals, or partners, and proceed to share based on their

\footnotetext{
${ }^{68}$ Vendulka Kubalkova, "Foreign Policy, International Politics, and Constructivism," in Foreign Policy in a Constructed World, ed. Vendelka Kubalkova, (Armonk: M.E. Sharpe, 2001), p. 19.

${ }^{69}$ Kubalkova, 2001, p. 22.
} 
interpretations of their respective identities. Actors also act in accordance with each other's expectations. Moreover, according to Peter Katzenstein ${ }^{70}$, identity is shorthand for varying constructions of nationhood and statehood of new states. Therefore, constructivists should proceed from identity to interest, and from interest all the way around again to the structure of the international system. ${ }^{71}$

Steve Smith claims contrary to the other constructivists that Nicholas Onuf's constructivism should be particularly relevant to foreign policy analysis, precisely because Onuf starts from the assumption that actors make their worlds, and this assumption lies behind most of the foreign policy analysis literature. Thus, Smith paraphrases that foreign policy is what states make of it. ${ }^{72}$

\section{Models of Foreign Policy Analysis}

Foreign policy analysis refers to the objectives that states pursue in their relations with other states and their choice of ways to achieve these objectives. Thus foreign policy analysis covers the interactions within states and amongst its diverse agents, as well the perceptions and misperceptions, the images of other states, and the ideologies and personal characters of everyone involved. For that reason, foreign policy analysis considers people who constitute governments and act on behalf of states as actors of international politics. Therefore, an important part of analyzing foreign policy has been

\footnotetext{
${ }^{70}$ Peter J. Katzenstein, "Introduction: Alternative Perspectives on National Security," in The Culture of National Security: Norms and Identity in World Politics, Peter J. Katzenstein, ed., (New York: Columbia University Press, 1996), p. 24.

${ }^{71}$ Kubalkova, 2001, p. 34.

72 Steve Smith, "Foreign Policy is What States Make of It: Social Construction and International Relations Theory," in Foreign Policy in a Constructed World, Vendulka Kubalkova, ed., (Armonk: M.E. Sharpe, 2001).
} 
the nature and impact of domestic politics and characters of political leadership. ${ }^{73}$ In other words, scholars who employ foreign policy analysis examining foreign policybehavior have chosen to focus on how states respond to the constraints and opportunities provided by their respective domestic and international environments as well as perceptions and characteristics of ruling elites. This approach allows one to compare the behavior of states in terms of their opportunities and constraints, for these vary from one state to another. ${ }^{74}$

In summary of half a century of foreign policy analysis ${ }^{75}$ one can thus say that although there are many variants of foreign policy analysis, each favoring a different specific domestic variable, they all share a common assumption that foreign policy is best understood as the product of country's domestic dynamics. ${ }^{76}$

\section{i. Rational Model}

The most extensively used model of foreign policy analysis has been the rationalactor model. The rational model, in which foreign policy choices are seen as the product of the goal-oriented deliberation of government, based on realistic ways of achieving sets of targeted goals. States or decision makers are viewed only as actors searching to maximize their goals in international and regional systems. As such, the decision-making unit is treated as a "black box" and little effort is made to understand the features and

\footnotetext{
${ }^{73}$ Kubalkova, 2001, p. 17.

${ }^{74}$ Lloyd Jensen, Explaining Foreign Policy, (Englewood Cliffs: Prentice-Hall, Inc., 1982), p. 8.

${ }^{75}$ Considering Richard C. Synder, H. W. Bruck, and Burton Sapin's book is as a first work on foreign policy analysis. See Richard C. Synder, H. W. Bruck, and Burton Sapin, Decision-Making as an Approach to the Study of International Politics (Princeton: Princeton University Press, 1954).

${ }^{76}$ Gideon Rose, "Neoclassical Realism and Theories of Foreign Policy,” World Politics, 1998, vol. 51, no. 1, p. 148.
} 
forces of internal politics affecting foreign policy-choice. Moreover, the rational model assumes that what is rational for one actor is rational for another. The rational model relies largely on the significance of international events to explain foreign policybehavior. $^{77}$

Therefore, according to the rational model of decision-making, leaders make a calculation in two basic dimensions: utility and probability. The model assumes that leaders are rational; they will attempt to maximize the expected utility. In other words, after all the available alternatives have been examined and the result of possible predictions has been acquired, leaders can choose their best possible way. ${ }^{78}$

Graham Allison's Essence of Decision methodically put rational choice in a particular political context of foreign policy-making, such as in case of the global power, the United States. He summarized large bodies of foreign policy analysis writing when he identified three approaches to the conduct of foreign policy: rational actor, organizational, and bureaucratic models. He then argues that the rational-actor model cannot by itself explain foreign policy. States are not homogenous "black boxes," and for this reason analysis should understand internal foreign policy-making mechanisms. ${ }^{79}$

In conclusion, the rational model requires that the rational leader has a stable and clear order of preferences and the ability to calculate courses of action through the process. In these circumstances, the leader will always choose a course of action most

\footnotetext{
${ }^{77}$ Jensen, 1982, p. 6.

${ }^{78}$ James E. Dougherty and Robert L. Pfaltzgraff, Jr. Contending Theories of International Relations: A Comprehensive Survey, $4^{\text {th }}$ ed. (New York: Longman, 1996), p. 463.

${ }^{79}$ Graham T. Allison, The Essence of Decision (Boston: Little Brown, 1971), p. 104.
} 
likely to produce a positive outcome that the leader would prefer over any other likely outcome. ${ }^{80}$

\section{ii. Organizational Model}

Graham Allison and Phillip Zelikow emphasize that organizational models highlight the judgment, functions, and actions of the large bureaucratic organizations which represent a government. According to the organizational model, the foreign policy behavior of a state can be understood by regular patterns of behavior of these large bureaucratic organizations. The main question of organizational model is: "from what organizational context, pressures, and procedures did the decision emerge?" ${ }^{\prime 1}$ Therefore, the organizational model focuses on decisions not in terms of instrumental rationality but as outputs of these large organizations functioning according to common bureaucratic behavior, usually referred to as 'standard operating procedures' ${ }^{82}$ In other words, it focuses on interaction among organizational players involved in bargaining games and competing preferences; it does not, therefore, aim to explain policy in terms of the outputs of actors' behavior.

Later, Allison extended these notions in terms of the following basic propositions: (1) foreign policies are to be viewed as organizational outputs; (2) the range of effective choice in foreign policy is limited by organizational routines; and (3) the situation constraining the range of possible decisions on the part of leaders is structured by organizational outputs. Thus, as a result of organizational competitions, foreign policy is

\footnotetext{
${ }^{80}$ Kubalkova, 2001, p. 28.

${ }^{81}$ Graham T. Allison and Philip Zelikow, $2^{\text {nd }}$ ed., Essence of Decision: Exploring the Cuban Missile Crisis (New York: Longman, 1999), p. 5.

${ }^{82}$ Walter Carlsnaes, "Foreign Policy," in Handbook of International Relations, Walter Carlsnaes, Thomas Risse and Beth A. Simmons, eds. (London: Sage Publications, 2002), p. 337.
} 
the outcome of the political process. Like all governmental actions foreign policy choices are also results from arguments of high governmental officials and compromise among them as well as the building of coalitions and counter-coalitions against each other organizational structure. Often it may be a policy that no participant fully favors, when 'different groups pulling in different directions yield a resultant' distinct from what anyone intended. ${ }^{83}$

\section{iii. Bureaucratic Model}

One of the models of foreign policy analysis concerns bureaucratic perspectives and interests. As with Allison's third model, the bureaucratic politics model builds on the organizational-process model, but instead of assuming control by leaders at the top, the bureaucratic politics model hypothesizes intensive competition among the decision making units. Thus, foreign policy choices are as the result of bargaining among the components of a bureaucracy in a state. The players are not guided by a long-term strategic master plan, but rather by conflicting conceptions of national, bureaucratic, and personal goals. ${ }^{84}$ The bureaucratic politics model considers foreign policies as "intranational political resultants: resultants in the sense that what happens is not chosen as a solution to a problem but rather results from compromise, conflict, confusion of officials with diverse interests and unequal influence; political in the sense that activity from which decisions emerge is best characterized as bargaining along regularized channels among individual members of government." 85

\footnotetext{
${ }^{83}$ Allison, 1971, p. 111.

${ }^{84}$ Dougherty and Pfaltzgraff, 1996, p. 466.

${ }^{85}$ Allison, 1971, p. 162.
} 
Graham Allison and Morton Halperin, in their joint article, mentioned that there are some complexities and nuances in bureaucratic politics. According to these scholars, bureaucratic complexity is the normal characteristic in most countries, including those that are weak. Thus, Allison and Halperin argue that most foreign policy choices reflect the conflicting interests of various government departments and military services which constantly compete to maintain their bureaucratic interests and goals and to maximize their involvement and influence in the policy-making process. ${ }^{86}$

In other words, foreign policy-making, according to the bureaucratic model, results from bargaining games among competing domestic 'players'. Decision are reached less by the rational choices of individual leaders than by the 'the pulling and hauling that is politics' among groups of policy-makers. ${ }^{87}$ To understand foreign policy decisions from this perspective, one must straighten out this web of players, their interests, their comparative influence, and the bargaining that occurs among them prior to a decision. Even though the leader may be offered a range of alternatives, powerful bureaucratic interests will have eliminated some options before the leader is asked to make a decision. Bureaucracy can make some options appear more attractive than others. $^{88}$

In conclusion, rather than focusing solely on the central foreign policy decision makers of the state, the bureaucratic politics approach emphasizes the role played by the

\footnotetext{
${ }^{86}$ Graham T. Allison and Morton H. Halperin, "Bureaucratic Politics: A Paradigm and Some Policy Implications," in Theory and Policy in International Relations, Raymond Tanter and Richard H. Ullman eds., (Princeton: Princeton University Press, 1972), p. 42.

${ }^{87}$ Allison and Zelikow, 1999, p. 346.

${ }^{88}$ Richard W. Mansbach, $3{ }^{\text {rd }}$ ed., The Global Puzzle: Issues and Actors in World Politics (Boston: Houghton Mifflin Company, 2000), p. 174.
} 
many bureaucrats involved in the foreign policy process. Therefore, bureaucrats have considerable influence in the shaping of foreign policy. At the same time, these bureaucrats are responsible for carrying out that policy and can therefore affect of implementation and outcome of foreign policy selected by the leader by moving reluctantly on an issue or perhaps refusing to act at all. ${ }^{89}$

\section{iv. Psychological Model}

Some scholars are interested in the motives underlying an individual's decisions and why some leaders reach different decisions than others even under similar circumstances. Some scholars claim that personal characteristics of political leaders will have more impact on foreign policy behavior if the political leaders are high level policy makers such as heads of state. Therefore the psychological approach studies foreign policy as a function of the desires and habits of a single leader. According to this view, leaders (kings, presidents or prime ministers) are the source of foreign policy; foreign policy decisions become a matter of personal taste and individual choice. Foreign policy is perceived not as an activity designed to achieve national or societal goals but as a policy of public relations whose objectives are to improve the image of the state, increase the popularity of the leader, and alter attention from domestic problems to illusory external problems or successes. ${ }^{90}$

\footnotetext{
${ }^{89}$ Jensen, 1982, p. 8.

${ }^{90}$ Robert Jervis, Perception and Misperception in International Politics (Princeton: Princeton University Press, 1976); Alexander L. George, Bridge the Gap: Theory and Practice in Foreign Policy (Washington, D.C.: United States Institute of Peace Press, 1993); Margaret G. Hermann, "Effects of Personal Characteristics of Political Leaders on Foreign Policy," in Why Nations Acts: Theoretical Perspectives for Comparative Foreign Policy Studies, Maurice A. East, Stephen A. Salmore, Charles F. Hermann, eds., (Beverly Hills: Sage Publications, 1978); Deborah W. Larson, Anatomy of Mistrust: U.S.- Soviet Relations During the Cold War (Ithaca: Cornell University Press, 1997) and Origins of Containment: A Psychological Explanation (Princeton: Princeton University Press, 1985); Stanley A. Renshon and Deborah W. Larson, eds., Good Judgment in Foreign Policy: Theory and Application (Lanham; Rowman \&
} 
Focusing on the leader himself/herself, several of his/her characteristics are proposed as influencing when, in general, his/her personal desires affect his government's foreign policy behavior. These are his/her interest on foreign affairs, his/her training in foreign affairs, and his/her general sensitivity to the international environment. Moreover, how leaders define situation, which foreign policy they choose, how important implications of those choices depend on for how they perceive such foreign policy choices.

Images are early defined as mental representations of situations, including perceptions of other actors, as well as the alternative choices that may be available in light of the goals established by decision makers, for instance, Ole Holsti's work on John Foster Dulles's psychology. Holsti found that Dulles had a "closed mind" toward the Soviets and that he tended to interpret all Soviet actions in a manner that reinforced his conception of Soviet leaders as international predators. ${ }^{91}$

According to Margaret Hermann, four personal characteristics affect foreign policy choices: leader's interests, experience in foreign policy, sensitivity to one's environment, and beliefs, motives and decision style. Interest acts as a motivating force. The reasons behind the leader's interest in foreign affairs may predetermine the course of action he will implement. Such reasons can include placing value on good external relations, fearing an enemy takeover, and seeing foreign policy as a way of gaining domestic support to his/her leadership. If the leader has an interest in foreign policy, a

Littlefield, 2003); Ali E. Hillal Dessouki and Bahgat Korany, "A Literature Survey and a Framework for Analysis," in The Foreign Policies of Arab States, Bahgat Korany and Ali E. Hillal Dessouki, eds., (Boulder: Westview Press,1984), pp. 5-18.

${ }^{91}$ Ole Holsti, "The Belief System and National Images: A Case Study," in Analyzing International Relations William D. Coplin and Charles W. Kegley, eds. (New York: Praeger Publishers, 1975). 
second personal characteristic of importance, then, is his/her training and experience in foreign policy issues. A third personal characteristic is general sensitivity to international and regional political environment. Sensitivity to the political environment indicates the extent to which a leader reacts to incoming incentives from the international and domestic environments in which he operates. Thus, the four types of personal characteristics that seem most relevant to foreign policy making are a political leader's beliefs, motives, decision style, and interpersonal style. Beliefs characterize the leader's primary ideas about the world. Motives of political leaders refer to the reasons why they do what they do. By decision style is meant preferred methods of making decisions. Interpersonal style is the way of approaching and dealing with the issue-areas. ${ }^{92}$

\section{v. Role Model}

The central concern of the concept of role model has been with patterns of human conduct; with expectations, identities, and social positions; and with context and social structure as well as with individual response. The role model consists of particular viewpoints regarding these patterns presumed to be influential in governing human behavior. $^{93}$

Moreover, K.J. Holsti describes role performance as behavior (decisions, and actions) and role prescriptions as the norms and expectations cultures, societies, institutions, or groups attach to particular positions. Role model thus emphasizes the

\footnotetext{
${ }^{92}$ Margaret G. Hermann, "Effects of Personal Characteristics of Political Leaders on Foreign Policy," in Why Nations Acts: Theoretical Perspectives for Comparative Foreign Policy Studies, Maurice A. East, Stephen A. Salmore, Charles F. Hermann, eds., (Beverly Hills: Sage Publications, 1978), p. 59

${ }^{93}$ See also Philippe G. Le Prestre, ed., Role Quests in the Post-Cold War Era: Foreign Policies in Transition (Montreal: McGill-Queen's University Press, 1997); Stephen G. Walker, ed., Role Theory and Foreign Policy Analysis (Durham: Duke University Press, 1987).
} 
interaction between the role prescriptions of the situation and the role performance of the decision-maker. $^{94}$

A strong role model, according to Stephen G. Walker, would answer four questions $^{95}$ :

1. What is a role?

2. What are its sources?

3. Under what conditions do various roles emerge?

4. Why are these conditions relevant?

According to role model, foreign policy behaviors derive primarily from decisionmakers' role conceptions, domestic needs and demands, and critical events or trends in the international environment. Therefore, role variables are somewhat more difficult to identify. These role variables are usually defined as expected rules of behavior for decision-makers, and other ruling elites who affect, formulate and implement foreign policies. Regardless of a given leader's psychological profile, when he/she takes on a specific role his/her behavior is modified considerably by the public's expectations of that role. Thus, the definition of a role affects larger political and societal variables. ${ }^{96}$ For instance, according to the idea of role model we can assume that given the less constrained role of the president of Azerbaijan, his personal characteristics are much more likely to significantly affect his country's policy than are the personal

\footnotetext{
${ }^{94}$ K. J. Holsti, "National Role Conceptions in the Study of Foreign Policy," in Role Theory and Foreign Policy Analysis Stephen G. Walker, ed., (Durham: Duke University Press, 1987), p. 7.

${ }^{95}$ Stephen G. Walker, "Role Theory and Foreign Policy Analysis: An Evaluation," in Role Theory and Foreign Policy Analysis Stephen G. Walker, ed., (Durham: Duke University Press, 1987).

${ }^{96}$ Theodore A. Couloumbis, Introduction to International Relations: Power and Justice (Englewood Cliffs: Prentice-Hall, Inc., 1982), p. 92.
} 
characteristics of the British Prime Minister who has probably a more constrained role in his/her country. This difference in definition between the role of the Azeri president and the role for the British Prime Minister allows us to visualize clearly the impact of role as an independent variable.

\section{vi. Linkage Model}

Foreign policy choices are driven by the interaction of international politics with the domestic politics that control the choices of foreign policy actors and the relationships between ruling elites and public opinion. Thus, the linkage model has been constructed based on the interdependence of domestic and international politics. That is, no foreign policies are made without regard to their domestic consequences and vice versa. Thus, the core of foreign policy as viewed in James Rosenau's linkage model is "any external behavior undertaken by the government of any national society when it copes with, or stimulates, changes in the external environment that contribute to keeping its essential structures within acceptable limits. ${ }^{, 97}$ From this perspective, therefore, a state acts to maintain the integrity and security of its basic political structures: when change occurs in either its internal or external environment which tends to disrupt these basic patterns, balancing behavior follows. Of critical importance here is Rosenau's stress on the linkage aspect between the two environments: the interdependence of internal and external environments, and behavior of the actors within that environment. Moreover, he also discusses that foreign policy is carried out in limited, centralized, decision-making

\footnotetext{
${ }^{97}$ James N. Rosenau, Linkage Politics: Essays on the Convergence of National and International Systems (New York: Free Press, 1969), p. 1.
} 
structure in a state, in contrast to domestic politics where power and responsibility are shared amongst a number of institutions and power bases. ${ }^{98}$

\section{Methodological Framework}

In my dissertation, I will employ a comparative case study approach in order to discover similarities or differences across foreign policies. The comparative method involves selecting what to examine (in this instance, states and their foreign policies) and determining patterns. It is 'comparative' because it involves comparing two or more states or, in some cases, one state at different time periods to determine similarities and differences. ${ }^{99}$ Adopting a comparative method, I am interested in identifying relationships and patterns of behaviors and interactions of Caucasus states' foreign policy processes. I search for similarities and differences between and among the selected cases in the Caucasus region for comparison. In other words, using the comparative method, I will make explicit and implicit comparisons, searching for common and contrasting features of the cases. Therefore, my primary goal of constructing an analytical framework is to understand and explain the comparative analysis of foreign policy-behavior of weak states.

\footnotetext{
${ }^{98}$ Rosenau, 1969, p. 45.

${ }^{99}$ See more about comparative method and case studies: Arendt Lijphardt, "Comparative Politics and Comparative Method," American Political Science Review, September 1971, vol. 65, no. 3, pp. 682-693; Harry Eckstein, "Case Study and Theory in Political Science," in Handbook of Political Science, Fred I. Greenstein and Nelson W. Polsby, ed. (Reading: Addison-Wesley, 1975); Alexander George, "Case Studies and Theory Development: The Method of Structured, Focused Comparison," in Diplomacy: New Approaches in History, Theory, and Policy, Paul G. Lauren, ed., (New York: Free Press, 1979), pp. 43-68; Alexander L. George and Timothy J. McKeown, "Case Studies and Theories of Organizational Decision Making," in Advances in Information Processing in Organizations, vol. 2, Robert Coulam and Richard Smith, eds., (Greenwich: JAI Press, 1985).
} 
The advantage of a comparative case study approach is that it allows for an indepth examination of different factors that produce foreign policy-behavior. ${ }^{100}$ The method also reveals a variety of complex patterns in new states' foreign policy behaviors that have not been covered in most international relations literatures.

In international relations, theories generally are stated in a causal mode. If X happens, then $\mathrm{Y}$ will follow as a result. Therefore a causal theory always includes some phenomenon that is to be explained. This is the dependent variable. In this dissertation, the dependent variable is foreign policy behavior. A causal theory also includes factors that are thought to affect the dependent variable. These are called the independent variables. In this dissertation, independent variables are strength of states, types of threats, and external commitments. A causal theory can include factors caused by independent variables and that cause the dependent variable. These are called the intervening variable. In this dissertation, the intervening variable is the characteristics and beliefs of the leaders of the weak state. All of these factors are called "variables" simply because it is the variation of each that makes it of interest to us. ${ }^{101}$

\footnotetext{
${ }^{100}$ Vendulka Kubalkova, ed., Foreign Policy in a Constructed World (Armonk: M.E. Sharpe, 2001); Walter Carlsnaes, "The Agent-Structure Problem in Foreign Policy Analysis," in International Studies Quarterly, September 1992, vol. 36, no. 3, pp. 245-70; Ryan K. Beasley, et al., eds., Foreign Policy in Comparative Perspective: Domestic and International Influences on State Behavior (2002); and Margaret G. Hermann, ed., "Leaders, Groups, and Coalitions: Understanding the People and Processes in Foreign Policymaking," special issue of International Studies Quarterly, 2001.

${ }^{101}$ More information about methodology of Political Science see Stephen Van Evera, Guide to Methodology for Students of Political Science (Cambridge: Defense and Arms Control Studies Program, MIT); Early Babbie, The Practice of Social Research, $7^{\text {th }}$ edition (Belmont: Wadsworth, 1995); Kenneth N. Waltz, Theory of International Politics (Reading: Addison-Wesley, 1979), especially first and second chapters; Gary King, Robert O. Keohane, and Sidney Verba, Designing Social Inquiry: Scientific Inference in Qualitative Research (Princeton: Princeton University Press, 1994); Arthur L. Stinchcombe, Constructing Social Theories (New York: Harcourt, Brace \& World, 1968); James D. Fearon, "Counterfactuals and Hypothesis Testing in Political Science," World Politics, January 1991, vol. 43, no. 2, pp. 169-195; Robert K. Yin, Case Study Research: Design and Methods, $2^{\text {nd }}$ edition, (Thousand Oaks: Sage, 1994).
} 
A second and important feature of foreign policy analysis relates to validity. Quantitative analyses of weak states' foreign policy actions make enormous and often heroic assumptions about leaders' motivations and behavior. Even though foreign policy studies do identify a relationship between weakness and foreign policy-behavior ${ }^{102}$, they only indicate correlations. Moreover, the causal mechanisms behind the correlations are largely derived without empirical examples. The demonstrated relationships may be false and have proven unreliable. For these reasons, case studies should therefore be employed to check whether the foreign policy process described in quantitative studies but not tested by them is present. ${ }^{103}$

The last one and half decade of politics in the post-Soviet states has been dominated by state-building process. These processes began prior to the collapse of the Soviet Union. Some of the post-Soviet states completed these processes (Baltic states) but some of the post-Soviet states remain far from their completion (Caucasus and Central Asian states). On the one hand, Baltic states, which existed as states between 1919-1939, have established strong state institutions and created a stable state and political life. The Baltic states have also obtained strong support from external powers, especially the United States and European states. On the other hand, Caucasian and Central Asian states, which do not have a real political legacy of statehood, except briefly for the Caucasus states (Armenia, Azerbaijan and Georgia) between 1918-1921 did not

\footnotetext{
${ }^{102}$ Eugene R. Wittkopf, "Foreign Aid and United Nations Votes: A Comparative Study,” American Political Science Review, 1973, no. 67, pp. 868-888; Neil R. Richardson, Foreign Policy and Economic Dependence (Austin: University of Texas Press, 1978); Neil R. Richardson and Charles Kegley, "Trade Dependence and Foreign Policy Compliance: A Longitudinal Analysis," International Studies Quarterly 1980, 24, pp. 191-222.

${ }^{103}$ Bruce M. Russett, "International Behavior Research: Case Studies and Cumulation," in Approaches to the Study of Political Science, Michael Haas and Henry S. Kariel, eds., (Scranton: Chandler Publishing Company, 1970), p. 428.
} 
have viable state institutions capable of controlling and administering territory, power and wealth, and of sustaining themselves beyond the political lives of individual leaderships. They also did not have strong support from external powers early 1990s.

Once I have established Armenia, Azerbaijan and Georgia in the 1990s as an appropriate setting for the study of foreign policy actions, specific policies needed to be isolated for study. I selected cases according to three criteria: first, cases should directly tap Armenia's, Azerbaijan's and Georgia’s dependent relationship with Russia. Each case represents an issue relevant to Armenian-Russian, Azerbaijani-Russian, and GeorgianRussian policy-makers. This criterion leads to cases most likely to uncover a relationship between weakness and foreign policy-behavior of these Caucasus states. In other words, this criterion assures crucial cases. Second, cases should represent similar issues under different administrations. For example, foreign policy dealing with intra-state conflicts, security issues, pipeline issues, and military bases are examined for each administration. This facilitates comparison across administrations. Third, cases should represent security as well as economic issue areas for each state and administration. This final criterion was chosen in response to the many foreign policy analysts who claim that issue-area is an important variable distinguishing types of foreign policy behavior. ${ }^{104}$

These guidelines provided me with a generous set of cases. From them I chose three issues (domestic politics-struggle for leadership, security issues- Karabagh, Abkhazian and South Ossetian conflicts, and economic issues- oil reserves and pipeline)

\footnotetext{
${ }^{104}$ Neil Richardson, Foreign Policy and Economic Dependence (Austin: University of Texas Press, 1978); Stephen G. Walker, ed., Role Theory and Foreign Policy Analysis (Durham: Duke University Press, 1987); Jerel A. Rosati et al., eds. , Foreign Policy Restructuring: How Governments Respond to Global Change (Columbia: University of South Carolina Press, 1994); and Philippe G. Le Prestre, ed., Role Quests in the Post-Cold War Era: Foreign Policies in Transition (Montreal: McGill-Queen's University Press, 1997).
} 
for which I will collect the most useful data. Three cases contain a variety of sub-policies, or decision points, which benefit from individual observation. Together they illustrate a broad range of new state foreign policy behavior and will act as a solid base for comparative conclusions both about foreign policy making and the foreign policy behavior in international relations theory and foreign policy analysis.

A final methodological point concerns the manner in which each case study is carried out. Alexander George suggests that "structured focused comparisons" contribute to theory building if the researcher asks a series of questions of a number of comparable cases. ${ }^{105}$ These questions aim to obtain the theoretically important elements of each case. The questions are standardized to ensure that each case is treated equally and to facilitate comparison. Following George's suggestion, I ask of each case whether particular criteria needed to confirm each theory are present. These criteria determine whether a case is a fair test of a theory. For example, one of my independent variables in the dissertation is that type of threats has a role in the foreign policy choices and implementation for the cases. ${ }^{106}$ If the type of threats does not have an effect on foreign policy behavior, then the case does not meet the criteria and should not be treated as a proper test case for my hypotheses. Once the criteria are met, I ask whether the policy outcome conformed with the theory's expectations. Returning to the same example, my hypotheses will only explain a case if indeed "type of threats" is implemented. Each case thus evolves as an investigation of the applicability of the theory or theories that apply to it. The comparison

\footnotetext{
${ }^{105}$ Alexander L. George and Timothy J. McKeown, "Case Studies and Theories of Organizational Decision Making," in Advances in Information Processing in Organizations, vol. 2, Robert Coulam and Richard Smith, eds., (Greenwich: JAI Press, 1985), p. 27.

${ }^{106}$ Alexander Wendt, "Collective Identity Formation and the International State," American Political Science Review, June 1994, vol. 88, no. 2, pp. 384-396.
} 
of the cases presented in the concluding chapter then allows for theoretical conclusions to be drawn.

Collections of verbal and written communication extracted from speeches, interviews, and statements will be helpful linked to foreign policy actions of the cases. I had informal interview with different policy makers and scholars from the Caucasus states, such as Gerard Libaridian, senior foreign policy advisor for Ter-Petrossian, Araz Azimov, deputy foreign minister of Azerbaijan, Hafiz Pashayev, former Azerbaijani Ambassador to the United States, Tedo Japaridze, former Georgian Ambassador to the United States, as well as scholars, Thomas Goltz, Svante Cornell, Fariz Ismailzade, and Rovshon Ibragimov. In addition to these primary sources, secondary sources, such as, newspaper and journal articles and analysis written by scholars will be used in accessing the recent redirection of Caucasus states' foreign policy in 1990s.

The time period covered is between 1991 and 1999, which in turn is divided into two sub-periods: 1991-1995 that I call the period of confusion and 1995 to 1999 that I call the period of consolidation.

Finally, the most omnipresent theoretical orientation sees foreign policy-behavior as a dependent variable. The patterns of foreign policy behaviors are to be understood examining various explanatory sources. The advantage of a case study approach is that it allows for, and indeed requires, an in depth examination of different factors which produces foreign policy actions. The method also reveals a variety of complex patterns in Armenian, Azerbaijani and Georgian foreign policy actions. 


\section{Organization of Study}

This dissertation has two major parts, one theoretical and conceptual and the other empirical and policy oriented. Part I (theory and illustrations) includes chapter 1-2, part 2 (case studies and policy implications) includes chapters 3-4 and part 3 chapter 5 (conclusion).

The need to structure the study in two distinct parts is essential if we are to understand the variables that shape foreign policy behavior, how these variables determine policy and what kind of outcome they can have for my cases. The study does not attempt to provide definitive answers to the numerous questions posed, but rather to highlight the difficulties and the possibility of foreign policy making and behaviors for new states.

\section{a. Chapter I}

In chapter one, I have defined the conceptual parameters and the research scope of the subject. I have reviewed the literature on international relations and foreign policy analysis.

\section{b. Chapter II}

In the second chapter, I shall demonstrate new post-Soviet states' foreign policy, distinguishing it from other categories of foreign policy-making and behavior. The bulk of the chapter focuses upon the development of a two-stage theoretical model of foreign policy (foreign policy-making and behavior) that might explain why the post-Soviet states choose different foreign policies. Rather than a single and parsimonious theory, I offer conditional generalizations, combining the different parts of the current mainstream IR approaches with foreign policy analysis and a clear classification regarding the 
conditions for the stages. I shall employ my independent variables (strength of state, type of threats, and external support) and intervening variables (characteristic and beliefs of leadership) to indicate why the post-Soviet states have different foreign policies.

\section{c. Chapter III}

The Caucasus states, Armenia, Azerbaijan and Georgia, are my main cases. In this chapter, I will look deeply at the background of Armenia, Azerbaijan and Georgia. The geography, history, and political culture of Armenia, Azerbaijan and Georgia create a legacy. These aspects are important insofar as they touch upon the legacy of the states and strength of state institutions, and finally their relations with the former imperial center, Russia. The imperial legacy can be an important determinant since it creates a certain affinity between states that have had the experience of a shared state. This chapter, thus, examines state-building processes of Armenia, Azerbaijan and Georgia, respectively.

\section{d. Chapter IV}

The chapter discusses the foreign policy making process itself. The chapter assesses the characteristics of foreign policy-making in Armenia, Azerbaijan and Georgia. How did leaders and political elites of Armenia, Azerbaijan and Georgia contribute in shaping policy options through their general perception of international politics in general and their understanding of Russian influence on their policies in particular? To what extent were leaders of these states able to steer their states away from Russian domination, and remain assertive, despite dependence on the former imperial overlord and other external players? The ways that Armenia, Azerbaijan and Georgian position themselves both in their immediate environment and in the international 
environment at large will determine to what lengths they will go to pursue their foreign policy choices.

The second part of this chapter illustrates a detailed outline of Armenia's, Azerbaijan's and Georgia's foreign policy behaviors. In particular, this chapter examines the relations between Armenia, Azerbaijan and Georgia with Russia. Examining Armenian, Azerbaijani and Georgian states' foreign policy behaviors will provide a basis from which to judge whether it has adopted a balancing, bandwagoning, or omnibalancing foreign policy stance. The extent to which this analysis validates or invalidates Armenian, Azerbaijani and Georgian experiences in terms of their foreign policy aspirations is examined.

\section{d. Chapter V}

Chapter five is the concluding chapter in which the study summarizes the accumulated evidence presented in the preceding chapters drawn from primary and secondary inquiry. The key features of foreign policy formulation and execution in Armenia, Azerbaijan and Georgia and their impact on the states themselves as well as on external actors, are singled out for analysis. In this chapter, I shall compare the foreign policy-behavior of the Caucasian states with those of the other post-Soviet states (especially the Baltic states and Central Asian states). Finally, I shall also try to explain why new independent states develop certain policies when they deal with their former imperial center.

\section{Boundaries of Subject}

The fundamental theme of this study is premised on the importance of both internal and external variables and their influence on foreign policy-making. Armenia, 
Azerbaijan and Georgia display many of the characteristics of foreign policy-making in weak states such as lack of strong state institutions, heavy dependence on external aid and assistance, and dominant role of leadership on foreign policy-making. Therefore, the choice of Armenia, Azerbaijan and Georgia is important because of their dual characters as both new and weak states, especially newly independent weak states. Their experiences in foreign policy formulation provide an example of the many difficulties faced by weak states. In a broader framework, Armenian, Azerbaijani and Georgian experiences represent typical experience of many weak states, wherein foreign policy is little more than an extension of existing leaders' interests, state strength and external support. 


\section{Chapter II}

\section{Introduction}

The international system has experienced major changes in the past fifteen years, with powerful consequences for weak states' foreign policy. Today, weak states receive more attention than during the Cold War because they are the source of many of the world's most serious problems. Weak states are not only responsible for creating many of the world's humanitarian disasters but their activities and relationships with other states have introduced many global and regional strategic challenges. Examples range from the devastating increase of the global AIDS epidemic to the massive increase of impoverished societies, to the socio-political religious differences facing the world community since the events of September $11,2001 .{ }^{107}$ According to G. John Ikenberry, "the most important characteristic of interstate relations after the Cold War is that a new distribution of power emerged, creating new asymmetries between powerful and weak states. These new power disparities are manifest precisely as the old order has been destroyed, and there are opportunities and incentives for states to confront each other over establishment of new principles and rules of order."

In this chapter, I will distinguish the foreign policy of newly independent weak states from other categories of states' foreign policy-making and behavior, for example, from the foreign policy of strong states. The bulk of the chapter will focus upon the development of a two-stage theoretical model of foreign policy (foreign policy-making

\footnotetext{
107 Jeanne A. Hey, "Introducing Small State Foreign Policy", Jeanne A. Hey, ed., 2003, Small States in World Politics: Explaining Foreign Policy Behavior, Boulder: Lynne Rienner Publishers, p. 1.; Francis Fukuyama, State-Building: Governance and World Order in the $21^{\text {st }}$ Century, (Ithaca: Cornell University Press, 2004), pp. ix-xi.

${ }^{108}$ G. John Ikenberry, After Victory: Institutions, Strategic Restraint, and the Rebuilding of Order after Major Wars, (Princeton: Princeton University Press, 2001), p. 4.
} 
and behaviors) that will help explain why the post-Soviet states such as the Caucasus states choose different foreign policies in different periods. I will use my independent variables (strength of state, type of threats, and external support) and intervening variable (leadership orientation) to explain why the post-Soviet Caucasus states have formulated and implemented different foreign policies.

In this dissertation, I will attempt to simplify the theoretical complexity of International Relations and Foreign Policy Analysis and identify the most important factors at work in the weak states' foreign policy-making process. I will employ Robert D. Putnam's 'two-level game' ${ }^{, 109}$ approach to illustrate relations between foreign policymaking and behaviors for weak states. This dissertation, therefore, centers upon the explanation of two factors: the level of domestic strain of weak states and their relations to the external world. In short, both the domestic and external factors influence the strength of the independent variables which in turn serve as the principal explanatory elements and determinant of foreign policy-behavior of weak states. ${ }^{110}$ Therefore, rather than having a single and parsimonious theory, I will offer conditional generalizations, combining different parts of the current International Relations and Foreign Policy Analysis approaches.

The approach taken in this dissertation focuses on the analysis or explanation of foreign policy behaviors. In initiating my inquiry, I address two important components:

\footnotetext{
${ }^{109}$ The two-level game framework is developed in Robert D. Putnam, "Diplomacy and Domestic Politics: The Logic of Two Level Games," International Organization Summer 1988, 42, pp. 427-60. Applications of the model can be found in Peter B. Evans, Harold K. Jacobson, and Robert D. Putnam, eds., DoubleEdged Diplomacy: International Bargaining and Domestic Politics (Berkeley: University of California Press, 1993); Helen V. Milner, Interests, Institutions, and Information: Domestic Politics and International Relations (Princeton: Princeton University Press, 1997).

${ }^{110}$ Daniel S. Geller, Domestic Factors in Foreign Policy: A Cross-National Statistical Analysis (Cambridge: Schenkman Books, Inc., 1985), p. 8.
} 
understanding why a state does what it does in foreign affairs and how a state's particular foreign policy may have developed. When analyzing foreign policy, we are searching for regular and understandable patterns-across time, space, and issues. Finally, the main query of this chapter will investigate the relationship between internal characteristics of a state and its foreign policy actions. Recent research on these questions provides different answers to identify consistent patterns of weak states' foreign policy behaviors. ${ }^{111}$ While most scholars agree that economic and security dependence influences foreign policy actions in some manner, they nevertheless, disagree on the nature and extent of that influence. The theoretical and empirical work treating weak states' foreign policy action has generated a confusing and often conflicting representation of how weak states develop foreign policies in the international arena. Several theories applied to a variety of countries present very different explanations of the process through which weak states make foreign policy. ${ }^{112}$ Therefore, it is my intention to examine and explain why weak states make the foreign policy choices they do. It is believed that the understanding of foreign policy-making can be increased by looking at foreign policy-behavior from a systemic, comparative and historical perspective.

\footnotetext{
${ }^{111}$ See, Jacqueline Anne Braveboy-Wagner, The Foreign Policies of the Global South: Rethinking Conceptual Frameworks (Boulder: Lynne Rienner, 2003); Jeanne A. K. Hey, ed., Small States in World Politics: Explaining Foreign Policy Behavior (Boulder: Lynne Rienner, 2003); Werner Bauwens, Armand Clesse and Olav F. Knudsen, eds., Small States and the Security Challenge in the New Europe (London: Brassey's, 1996); Miriam F. Elman, "The Foreign Policies of Small States: Challenging Neorealism in Its Own Backyard," British Journal of Political Science, 1995, 25, pp. 171-217; Peter J. Katzenstein, Small States in World Markets: Industrial Policy in Europe (Ithaca: Cornell University Press, 1985).
}

112 A. G. Hopkins, "Quasi-states, Weak States and the Partition of Africa," Review of International Studies 2000, 26, pp. 311-320; Peter Dauvergne, ed., Weak and Strong States in Asia-Pacific Societies (Canberra: Allen \& Unwin, 1998); Joe S. Migdal, Strong Societies and Weak States: State-Society Relations and State Capabilities in the Third World (Princeton: Princeton University Press, 1988); Michael Handel, Weak States in the International System (London: Frank Cass, 1981), Marshall R. Singer, Weak States in a World of Powers: The Dynamic of International Relationships (New York: The Free Press, 1972). 
The newly independent Caucasus states were upon their establishment weak states. The most urgent problems facing these newly independent republics following their independence were domestic ones. The development of foreign policies of these states are shaped and influenced by the institutional legacies of imperialism, the conditions of domestic political structure and security, the perceptions and interests of leaders, and one's position in the international arena. ${ }^{113}$

The consequences of certain structural and functional features of regional systems and the shifting roles of major powers shape the foreign policy of new states. The first and most important goal of new states is to maintain their territorial integrity and sovereignty. Therefore, an idea of national interest is most clearly stated when the new states' borders and territories are threatened. However, national interest is not often clearly defined in weak states, thus allowing leaders flexibility in defining and articulating the national interest.

Leaders in weak states have a specific political and even personal interest in strengthening the state's position in the international system; in this way their activities conflate regime interests with national interests. They frequently identify their interests with the defense of the state against external threat and/or internal disunity. Therefore, there are difficulties in studying the foreign policies of weak states in the same way that is usually done for the foreign policies of strong states. On the other hand, studies of the foreign policy of strong states tend to approach the subject by way of process, i.e., who,

\footnotetext{
${ }^{113}$ Christopher Clapham, "Comparative Foreign Policy and Developing States," in Foreign Policy Making in Developing States: A Comparative Approach, Christopher Clapham and William Wallace, eds., (Westmead: Saxon House, 1977), p. 173.
} 
where, and how policy is made. ${ }^{114}$ These studies identify the continuities of policy and the enduring national interests which need to be taken into account by identifying the bureaucracies, political parties, interest groups, public attitudes, and external influences which impose a standardized pattern of policymaking. However, these approaches fail for most of the weak states because such patterns are not tangible. ${ }^{115}$

\section{Independent Variables}

\section{a. Weak State}

Ruling elites in weak states generally aim to maintain their authority and resist challenging internal and external oppositions, coordinate state institutions for its benefits, and control and respond to public pressures and demands. Thus, as a result of the weakness of state institutions, internal conflicts and competition among different factions of the political elite significantly shape state policies and actions. On the one hand, we can understand that states are weak because of the lack of strong state institutions and settled bureaucracy as well as geographical, physical, or major economic constraints. On the other hand, to define a weak state sometimes is not an easy task. Some states, which are normally strong may for the time being or under certain circumstances become weak because of conflict among competing political elites, ethno-national divisions, repression, or a combination of all. There are several characteristics of problems that weak states face. First, weak states usually provide opportunities for ethnic, religious, or other inter-

\footnotetext{
${ }^{114}$ Clapham, 1977, p. 174.

${ }^{115}$ Clapham, 1977, p. 175.
} 
communal conflicts in multi-ethnic societies. Second, weak states are commonly ruled by authoritarian leaders, whether elected or not. ${ }^{116}$

Let us define strong states so that one can understand key differences between a strong state and a weak state. Dauvergne defines strong states as having or possessing the ability to maintain political and social control, to make effective policies to maintain the unity, provide basic services, manage and control the national economy, and to retain legitimacy. Contrarily, weak states are characterized by centralized control and eliminating opposition, in part through repression, authoritarian rules, political maneuvers, and high corruption. ${ }^{117}$

I propose six features necessary to establish any useful theoretical framework for the analysis of weak states in the Caucasus region, as summarized in the chart below:

\footnotetext{
${ }^{116}$ Robert I. Rotberg, "Failed States, Collapsed States, Weak States: Causes and Indicators," in State Failure and State Weakness in Time of Terror, Robert I. Rotberg, ed. (Washington, D.C.: Brookings Institution Press, 2003), p. 4.

${ }^{117}$ Peter Dauvergne, "Weak State," in Weak and Strong States in Asia-Pacific Societies, Peter Dauvergne, ed., (Canberra: Allen \& Unwin, 1998), p. 2 and p. 6.
} 


\section{$\underline{\text { Indicators of Strong State versus Weak State for post-Soviet states }}$}

STRONG STATE

\begin{tabular}{|c|c|c|}
\hline $\begin{array}{c}\text { Political } \\
\text { Succession }\end{array}$ & $\begin{array}{l}\text { There is a method for determining } \\
\text { how succession originates and is } \\
\text { followed every time. }\end{array}$ & $\begin{array}{l}\text { No method exists, or one exists, } \\
\text { but it is not always followed; } \\
\text { coups, plots, assassinations take } \\
\text { place. }\end{array}$ \\
\hline $\begin{array}{c}\text { Political } \\
\text { Uniformity }\end{array}$ & $\begin{array}{l}\text { Different ethnic, religious, and other } \\
\text { communal, social and political } \\
\text { groups and elites accept legitimacy } \\
\text { of ruling elites. There is a consensus } \\
\text { on social and political rights of all } \\
\text { different groups. }\end{array}$ & $\begin{array}{l}\text { Ethnic, social and political } \\
\text { groups internally divided and } \\
\text { have violent conflict with each } \\
\text { other. These groups challenge } \\
\text { the fundamental rules of political } \\
\text { system. }\end{array}$ \\
\hline $\begin{array}{l}\text { Internal } \\
\text { Legitimacy }\end{array}$ & $\begin{array}{l}\text { Regimes or institutions representing } \\
\text { the public (whether democratic or } \\
\text { not) are accepted as efficient and } \\
\text { competent. }\end{array}$ & $\begin{array}{l}\text { There are challenges to the } \\
\text { rulings of existing regime and its } \\
\text { institutions. }\end{array}$ \\
\hline $\begin{array}{l}\text { Coherence of } \\
\text { State } \\
\text { Institutions }\end{array}$ & $\begin{array}{l}\text { State institutions are in place. There } \\
\text { are clear definitions of authority and } \\
\text { respected jurisdictional boundaries } \\
\text { in and among state institutions. }\end{array}$ & $\begin{array}{l}\text { State institutions are extremely } \\
\text { weak and localism prevails. } \\
\text { There is widespread corruption } \\
\text { and overlapping among state } \\
\text { institutions. }\end{array}$ \\
\hline $\begin{array}{l}\text { Foreign } \\
\text { Policy }\end{array}$ & $\begin{array}{l}\text { Public is willing to accept } \\
\text { government's definition of country's } \\
\text { external role and interest. }\end{array}$ & $\begin{array}{l}\text { Foreign policy is highly } \\
\text { controversial; existing policies } \\
\text { and changes in policy are } \\
\text { routinely challenged by } \\
\text { important political and ethnic } \\
\text { groups. }\end{array}$ \\
\hline $\begin{array}{l}\text { Legacy of } \\
\text { Past }\end{array}$ & $\begin{array}{l}\text { Strong states have self-sustaining } \\
\text { state capacity, a stable regime, and } \\
\text { durable institutions which were } \\
\text { created by ex-imperial center. }\end{array}$ & $\begin{array}{l}\text { The legacy of empire included } \\
\text { violent competition for } \\
\text { leadership among elites, } \\
\text { fragmented state structure, and } \\
\text { ethnic turmoil. }\end{array}$ \\
\hline
\end{tabular}

\section{Political Succession:}

In weak states, the superiority of the ruling elite is always present. The ruling elite control the central state mechanism over any other organized source of power within the political community. For this reason, oppositions are easily suppressed and governments are generally overthrown to seize state power without having a general mobilization of support in the country as a whole. 
Political succession triggers a political crisis because weak states are naturally unstable; consequently, the issue of political succession is critical in weak states, where stability to a large extent rests on the leaders. Coup d'etat and assassination attempts are a common threat in weak states. For instances, see the occurrence of fraud in presidential elections in 1996 and the sudden resignation of Ter Petrossian in 1998 in Armenia; the depositions of Mutalibov in 1992 and Elchibey in July 1993 in Azerbaijan; and the overthrow of Gamsakhurdia in December 1991 in Georgia all exemplify such activities in the Caucasus.

The weakness of conventional and organized channels of communication, which can both pressure and support the government, has the contradictory effect of making governments both powerful and unstable. Dirty tricks and other kinds of political maneuvers of survival, including the highly clan-based rearrangement and appointments of cabinets, have all reflected a lack of confidence in the state institutions. ${ }^{118}$ For instance, in 1992 alone, Azerbaijan changed its defense ministers three times during the war against Armenian forces in Karabagh. It is an example of how Azerbaijani state and its institutions were fragile. Haydar Aliyev appointed his former colleagues (from Azerbaijan's KGB) and people from his own region (Nakhcehivan) to important government posts, including his son to the vice chair of the Azerbaijani Petroleum Company (SOCAR). Therefore, political and "personal survival" are the central issues occupying the attention of weak states' leaders.

\footnotetext{
118 Joel S. Migdal, Strong Societies and Weak States: State-Society Relations and State Capabilities in the Third World (Princeton: Princeton University Press, 1988), p. 223.
} 


\section{Political Uniformity:}

A newly independent weak state lacks effective and responsible government. Resources are limited and insufficient. With the removal of a strict form of imperial rule, long suppressed ethnic divisions and tensions can emerge to threaten a new weak state with separatist tendencies. The problem in many new weak states is not only restraining power, but one of accumulating sufficient power to make the government's rules effective across the country and amongst diverse ethnic groups. Moreover, a newly independent weak state operates for the benefit of the ruling elites and groups within it, leading to political conflict for control over the state. Both ruling and opposition elites tend to express clan, tribal and/or sectional loyalties, not national ones in many weak states.

Divided elites and the emergence of powerful competitors to the old imperial nomenklatura and new nationalist elite contribute to the deterioration of the state from within. In weak states, loyalties to non-state institutions, like clans, tribes, regionalaffinity, run high. Leaders employ nepotistic methods to secure employment in highranking state positions. In other words, special ties among the ruling elites seriously influence the composition of state institutions: common regional origins; shared ethnic, tribal backgrounds; working in the same posts previously, etc. ${ }^{119}$ Therefore, there is no institutionalized political unity among the political elite and masses.

${ }^{119}$ Migdal, 1988, p. 35. 


\section{Internal Legitimacy:}

Kalevi J. Holsti argues that legitimacy is the critical variable when attempting to explain the relative weakness and strength of states. ${ }^{120}$ In weak states, over a period of time regimes oppress opposition groups, minorities and communities; regimes, therefore, fail to develop or destroy internal legitimacy. In addition, leadership of weak states may lose their internal legitimacy when the leadership commands limited authority, loyalty and/or a variety of feuding groups and factions. Paramilitary groups and factions typically arm themselves in order to challenge the regime or to resist attempts to establish order.

Therefore, the critical feature absent from a weak state is authority. When authority becomes fragmented or disappears altogether, the government of a weak state loses its legitimacy in society. Rules exist based on force, corruption, or terror. Due to lack of unified, legitimate power, all sorts of paramilitary and political groups and factions battle against each other, such as warlords, gangs, religious movements, and clans, to increase their power and influence in the political system.

Thus, weak states are limited in their capacities and legitimacy to shape the political order within the territories under their authority. ${ }^{121}$ Internal legitimacy in a weak state rests on a kind of political contract between ruling elites and minority groups who are the power base of the leadership, such as Tikriti clan for Saddam Hussein.

\footnotetext{
${ }^{120}$ Kalevi J. Holsti, The State, War, and State of War (Cambridge: Cambridge University Press, 1996), pp. 82-98.

${ }^{121}$ Kalevi J. Holsti, Taming the Sovereigns: Institutional Change in International Politics (Cambridge: Cambridge University Press, 2004), p. 57.
} 


\section{Coherence of State Institutions:}

Weak states also have incoherent institutions. Power is accumulated in the hands of the executive branch. If legislatures do exist, it usually typifies "rubber-stamping" machines. Therefore, institutional fragilities and structural flaws contribute to weakness. Weak institutionalization leads to the dominance of the ruling elites in all areas of politics. Leaders regularly disregard the difference between the public interests and their own personal interests. In weak states, the central government's rule often does not reach into different regions of the country. The armed forces are in chaos and confused, unable to recruit or to function as potential regular army to defend the country's borders. Draft resistance is widespread. Army units, because their members are poorly trained and paid, badly housed, and inadequately fed, may sell their equipment in order to survive.

\section{Foreign Policy:}

A weak state's foreign policy is mainly a response to domestic threats, not external ones. Weak states using foreign policy attempt to influence the external environment in ways favorable to the maintenance of the regime in power. In other words, for a weak state, foreign policy is domestic policy pursued by other means. Therefore, foreign policy turns a domestic policy carried beyond the boundaries of the state.

\section{Legacy of Past}

One factor in determining the character of the state has been the legacy of the past, which especially provides a reference point for newly independent states. Most of the new states were established after a colonial empire collapsed. When empires come crashing down, they leave institutional remnants spread across the imperial land: pieces 
of bureaucracies, military units, economic networks, administrative districts, as well as demographic and ethnic patterns that carry the marks of the imperial past. ${ }^{122}$ Jack Synder calls imperial remnants the "detritus of empire". ${ }^{123}$ There are several legacies of the imperial past: since the dissolution of the imperial structure was replaced with ethnically defined national republics and territorial boundaries, most new states contain ethnically defined minorities in their territories. In this case, nationalism becomes a forum that appeals to ruling elites and the main ethnic-national groups in the domestic and international political arena.

Another remnant from empire is the pattern of patronage ties, including those running from the imperial center to the periphery as well as more local networks within the periphery. According to Alexander J. Motyl, core elites make foreign and defense policy, control the armed forces, and regulate the economy; "peripheral elites" execute core policies and orders. ${ }^{124}$ The separation of these networks as a result of imperial collapse does not eliminate their political significance. Patronage networks remain the most institutionalized structures in the periphery. The break down of the patronage mechanism for obtaining resources forces the peripheral elites to adopt new strategies so they can mobilize support and drives the peripheral elites into a competition amongst themselves for control over the state and its resources.

Finally, ethnic identity and patterns of ethnic settlement are themselves an institutionalized legacy of empire. Authority moved from the imperial center into the

\footnotetext{
122 Jack Snyder, "Introduction: Reconstructing Politics Amidst the Wreckage of Empire" in Post-Soviet Political Order: Conflict and State Building, Barnett R. Rubin and Jack Snyder, eds., (London: Routledge, 1998), p. 1.

${ }^{123}$ Synder, 1998, p. 1.

${ }^{124}$ Alexander J. Motyl, Imperial Ends: The Decay, Collapse, and Revival of Empires, (New York: Columbia University Press, 2001), pp. 86-87.
} 
peripheral states, defined individuals' identities through passport entries, and institutionalized practices that favored titular ethnics in their home republics. For example, before the conflict between Abkhazian and Georgian forces, only 18 percent of the population was Abkhazians in Abkhazia but Abkhazians control all political institutions in Abkhazia.

The legacy of the imperial past has several influences on newly independent states. A new state organizes itself within the old imperial border; otherwise, it can start conflicts with neighboring states. Challenging borders often leads to new conflicts within and outside borders. A new state or ethnic/national minorities within the new state, is often reluctant to accept the legitimacy of territorial boundaries handed down from an imperial distribution. Therefore, territorial and national conflicts between new states and within new states as institutional remnants of the imperial past make survival the most important goal of newly established weak states' foreign policies.

\section{b. Origins of Threats}

The primary responsibility of a state to gain its legitimacy is to provide security for its peoples from domestic and external threats. Since the precondition of security by removing threat and violence in the public arena was an integral part of the process, it makes sense to consider threat perception both in internal and external security frames within the broader process of political and security structures of weak states. ${ }^{125}$ Yet the admission that external and internal threats are linked raises some difficult methodological problems: in particular, how are threats to be judged and assessed and how should we compare, for example, the threat posed by the Zvidaist movement in

\footnotetext{
${ }^{125}$ Keith Krause, "State-Making and Region-Building: The Interplay of Domestic and Regional Security in the Middle East," The Journal of Strategic Studies, September 2003, vol. 26, no. 3, p. 106.
} 
Georgia in response to the threat posed by a military buildup in Abkhazia to Shevardnadze's government.

Buzan notes that "weak states either do not have, or have failed to create, a domestic political and societal consensus of sufficient strength to eliminate the largescale use of force as a major and continuing element in the domestic political life of the nation." ${ }^{126}$ Internal threat to the state is the single most important obstacle to establishing a strong state. In general, internal threats arise not from any external challenge to the integrity of the state but from internal challenge to ruling elites, which may or may not be supported from outside. When such a threat emerges, it is usually the product of political competition or leadership crisis among ruling elites or extraordinary circumstances that create opportunities for ethnic minorities to seek or gain de facto independence or autonomy. Such challenges direct the attentions of governments of weak states and are considered as foreign policy priorities because declarations of autonomy or independence by ethnic minorities may attract attention of their ethnic relatives in other countries. Moreover, because governments of weak states are not strong, they need external assistance to resolve their problems with their ethnic minorities.

The dilemmas facing the new state were precisely symbolized in its ruling elites, who on the one hand, need to relate the minority ethnic groups to the national level of politics, and on the other, keep a certain balance between demands of nationalist elites of titular nationality. Therefore, the likelihood of internal threat depends on the type of regime that emerges and on the degree of institutionalization of politics in new states. When state institutions are weak and when there is political competition between elites,

\footnotetext{
${ }^{126}$ Barry Buzan, People, States, and Fear: An Agenda for International Security Studies in the Post-Cold War Era, (Boulder: Lynne Rienner, 1991), p. 99.
} 
and when there are internal ethnic conflicts, leaders of new states view foreign policy as an option to resolve these internal threats. However, in turn, this may create a reason for strong neighboring states to intervene, whether in form of protecting their ethnic kin and/or security interests in the region. Moreover, even if the state has not been threatened internally, foreign policy has often focused and linked primarily on its governments' concerns for domestic security.

External threats, under the conditions of internal instability and weakness, make weak states submissive in respect of external support. That is, weak states, instead of forming alliances to balance the power of the most threatening state, are expected to jump on the bandwagon and/or support the dominant external power. ${ }^{127}$ In weak states, the ruling elite may overemphasize external threats and pay tribute to past glory of history, especially victories and/or traumatic defeats to justify the governments' actions in the minds of societal members. ${ }^{128}$ In essence, weak states promote "heartening" nationalistic dialogue and discourse in order to neutralize domestic challenges to its domination.

The dependency of weak states to external support of major powers in the region can undermine the rule of weak states' leaders' legitimacy. This can take many forms. In some cases, external powers can support political or ethnic groups within the state that either work to overthrow the ruling regime or to divide the state. This occurred, to some extent, in the early 1990s in the Caucasus. In other cases, constant demands requested by external powers can destabilize the ruling elite's legitimacy or fail to encourage broadening it base of legitimacy in the country sensitive to the legacy of imperial control.

\footnotetext{
${ }^{127}$ Jack Snyder, Myths of Empire: Domestic Politics and International Ambition, (Ithaca: Cornell University Press, 1991), p. 5.

${ }^{128}$ Vamik Volkan, Bloodlines: From Ethnic Pride to Ethnic Terrorism, (Boulder: Westview Press, 1998), and Charles Tilly, Identities, Boundaries, and Social Ties, (Boulder: Paradigm Publishers, 2005).
} 
Both Azerbaijan and Georgia seem to fit this pattern. Further, by giving their support to the critical domestic political actors, external powers can reinforce the external threats that the weak state or ruling elite in the state faces. This way a regional power pushes the weak state and its ruling elite to face shifting the balance of power in favor of the major power's ally in the region. This would describe Russian-Armenian and TurkishAzerbaijani relations in the early 1990s. Each of these processes drives weak regimes to rely domestically on higher levels of repression and political control, weakening external and internal security, as well as forcing weak states into asking help from its potential external enemies. For instance, both Azerbaijan and Georgia asked for Russian assistance even though their ruling elites considered Russia as a potential external threat in the early 1990s.

\section{c. External Support to Weak States}

The collapse of the bipolar system has increased the role of regional strong states in their respective regions. Maintaining a regional balance has become more important than ever before. Moreover, the relations between weak and strong states depend not only on the relationships amongst the strong states in the region, but also the geopolitics and geoeconomics of the weak states. In particular, the distance between weak state(s) and a major power and its political and economic environment play important roles. For example, the United States' position in the Caucasus is defined according to the power relations among the regional and ex-imperial power, i.e., Russia, the most active player in the region, and the other significant but lesser regional strong states, i.e., Turkey and Iran as well as the location and resources which weak states of the Caucasus have. 
Therefore, the weaker the state, the more likely it will respond to external challenges and balances against rising regional hegemons. Because their political, economic, and military capabilities are relatively low compared to others, weak states must be highly sensitive to the external environment. Their survival is at stake and the costs of being victimized are high. Moreover, the influence of external major powers on weak states depends on the presence of two components: (1) the external major power must want to get involved with weak states; (2) the external major power must demonstrate or have the capability to quickly mobilize the necessary resources to support the weak state and/or employ a security regime to contain both external and internal threats. The external support provided to weak states varies considerably from the geopolitical and geoeconomical environment to the type of international and regional system in which the weak state finds itself. Furthermore, weak states can find two kinds of external conditions: a weak state may find itself within a series of threatening and expansionist powers which is not being challenged by another major power, or it can have 'a power of the weak' that weak states have gained advantage from the competition between/among major powers and their interests in their regions. ${ }^{129}$

Therefore, a state may be economically weak, military impotent, and politically unstable; nevertheless, its weakness can be a source of bargaining power if a major power perceives the territory of weak states to be of strategic and economic importance and is prepared to commit political, military and economical assistance. For instance, when a regional hegemonic power or ex-imperial power is able to guarantee its access to military bases and establish political influence, and especially if the regional system is at the same

\footnotetext{
${ }^{129}$ See Bjol Erling, "Small States in International Politics," in Small States in International Relations, August Schou and Arne O. Brundtland, eds., (New York: Wiley Interscience Division, 1971).
} 
time divided, it is easy for external major powers to spread local rivalries to maintain their influence in the region. On the contrary, when the major powers are divided, as under Cold War bipolarity, weak states are able to take advantage of major powers' rivalry to secure survival, aid and arms from one or many of the major powers, thus enabling leaders of weak states to practice highly flexible foreign policies to maintain their sovereignty.

The external environment influences weak states' foreign policy in several ways. First, the influence of weak states can increase if the initial commitment of global and/or major powers increases and the competition among major powers becomes expanded in the region. For example, although the Cold War has ended, geopolitical and geoeconomic competition continues among major powers. A regional system has been forming around the Caucasus in response to Russia's declining power, rising local nationalism, and the arrival of major Western energy corporations in the 1990s. The region contains major oil and gas deposits that have attracted American and European interests.

Second, the bargaining power of weak states, located in strategically and economically important regions, will be increased if there is a clear and visible commitment by major powers to the region, such as American support to the BakuCeyhan pipeline project. Washington's determination to the construction of the BakuCeyhan pipeline route to the Caspian has helped both to separate and shield Azerbaijan and Georgia from the Russian sphere of influence, in turn serving as a source of pressure on Moscow to remain active in the region.

Third, a weak state can sometimes move against a major power under certain conditions. These conditions are the degree of involvement of other major powers in the 
region and any fear that might negatively affect relations of the regional hegemon with other major powers who have interests in the region. For example, Azerbaijan under Elchibey's leadership withdrew from the CIS because Elchibey perceived Russia as an external threat and Turkey to be a potential support his leadership. ${ }^{130}$

Fourth, weak states can use international organizations to mobilize support for their foreign policy objectives. For example, the Caucasus states are active participants in NATO's Partnership for Peace (PfP) and they have also participated in a number of PfPsponsored cooperative regional conflict management exercises; moreover, Azerbaijan and Georgia desire to become members of NATO in the near future. ${ }^{131}$

Fifth, a weak state will be able to resist collective sanctions if it receives support from bordering states and if the collective sanctions are not universally or equally applied by members of the international organization. For example, Georgia and Iran serve as a transit route for goods en route to Armenia, which blockaded from west by Turkey and east by Azerbaijan.

Furthermore, the possibilities for external support to weak states depend on the types of international and regional systems in which they operate (hegemonic systems, confrontation systems, and security communities). In addition, external support is also influenced by the importance of geographic location as well as according to major powers' domestic politics. For example, because of a strong Armenian lobby, Armenia was the second largest per capita recipient of American foreign aid during 1990s.

\footnotetext{
${ }^{130}$ Robert V. Barylski, "Russian, the West, and the Caspian Energy Hub," The Middle East Journal, Spring 1995, vol. 49, no. 2, p. 220.

${ }^{131}$ Phillip Petersen, "Security Policy in Post-Soviet Transcaucasia," European Security, Spring 1994, vol. 3 , no. 1, p. 42 .
} 
Moreover, the Armenian lobby in Washington, D.C. lobbied the United States Congress members to pass resolution banning American government assistance to Azerbaijan in 1993 even though Armenia occupied twenty percent of Azerbaijani territory and the United Nations Security Council condemned this occupation. ${ }^{132}$

In conclusion, the belief systems and goals of ruling elites in dominant major powers also create essential parameters for the policy of the weak states. In general, the type of regional security system in which the weak state has to operate makes a considerable difference in its foreign policy choices and behavior. For the weak state, the regional environment is a much more important variable than for a major power. Finally, while security for weak states can be generated by both external and internal conditions, support from external powers is essential for the survival of the leadership of weak states. This support can come from one of two sources: (1) from the ex-imperial power who governed the region before; (2) from direct involvement of the global power and/or regional major powers that have enough power to influence circumstances and balances in the region.

\section{d. Leaders}

The role of personal variables, such as psychological conditions and individual belief systems of leaders in foreign policy-making, varies significantly among experts on the area. ${ }^{133}$ Obviously, the characteristics and beliefs of key decision-makers do make a

\footnotetext{
132 Tadeusz Swietochowski, Russia and Azerbaijan: A Borderland in Transition (New York: Columbia University Press, 1995), p. 221. United Nations accepted binding and non-binding several resolution on the Karabagh problem from April 1993 to March 2008 such as resolution numbers of 822, 853, 874 and 884.

133 Jack S. Levy, "Political Psychology and Foreign Policy," in Oxford Handbook of Political Psychology, David O. Sears, Leonie Huddy, and Robert Jervis, eds., (New York: Oxford University Press, 2003), pp. 253-284; Jack S. Levy, “Prospect Theory, Rational Choice, and International Relations,” International Studies Quarterly, March 1997, vol. 41,no. 1, pp. 87-112; Daniel Kahneman and Amos Tversky, eds. Choice, Values, and Frames, (Cambridge: Cambridge University Press, 2000); Barbara Farnham, ed.,
} 
difference in foreign-policy behavior. Personal characteristics refer to an individual's training, work experiences, interests, personality, and beliefs. In other words, personal characteristics play a complex role in individual level analysis. The chances of finding a relationship between a leader's personal characteristics and his government's foreign policy increase if the researcher examines the characteristics of leaders and takes into account the specific circumstances discussed above, especially for newly independent states which do not have strong state institutions and no clearly defined national interests. Under these circumstances leaders possess more authority because their states lack effective and responsive state institutions, especially public and parliamentary discussions. In essence, authoritarian practices allow leaders of weak states to shape their government foreign policies individually.

General beliefs refer to a leader's 'fundamental assumptions' about the nature of politics. General beliefs of leaders about fundamental issues of history and their perceptions of external challenge and internal capabilities influence foreign policymaking processes and foreign policy choices.

In summary, beliefs, personality, interest, and training in the political environment serve as indicators of the relationship between a leader's personal characteristics and his/her approach on foreign policy issues. These four variables indicate how much attention leaders will pay to foreign policy problems, how many options of foreign policy the leaders are likely to have, and how consistent the foreign policy behaviors of the state will be. In other words, the leaders' personal characteristics, such as their characteristics in general (across situations and roles) and specific (for political situations and roles)

Avoiding Losses/Taking Risks: Prospect Theory and International Conflict (Ann Arbor: University of Michigan Press, 1994). 
beliefs and interests, influence their foreign policy-behavior. The key point in the process of foreign policy-making is that decisions made by leaders are both related internal and external political in nature. ${ }^{134}$

Thus, strong personalities and personal beliefs and views may account for a significant part of foreign policy-behavior. The psychological environment frames the notion that how leaders perceive the world is at least as important for explaining their actions as is the world's actual condition. Consequently, the personalities of leaders and the dynamics of leaders' behaviors become central factors in foreign policy analysis.

Personality, or more precisely, personal leadership, is no doubt important in the making of foreign policy among weak states. However, while individual leadership may be expressed in a distinctive style, any radical break of foreign policy would appear to arise primarily from changes in the very nature of the domestic political environment in relation to changes in the external environment. Moreover, the patterns that leaders exhibit in foreign policy stem from their "learning" in domestic politics. This learning shapes the way they approach varying foreign policy issues, and it is particularly important for any leader who has had little, if any, prior experience in international politics.

Moreover, personal characteristics will have more impact on foreign policy in crisis conditions that force the leader to define or interpret crisis conditions. In crisis situations, the leader is likely to actively participate in the decision-making process. Two kinds of personalities of leaders in weak states shape their policies: self-oriented and

\footnotetext{
${ }^{134}$ Margaret G. Hermann, "Effects of Personal Characteristics of Political Leaders on Foreign Policy," in Why Nations Act: Theoretical Perspectives for Comparative Foreign Policy Studies, Maurice A. East, Stephen A. Salmore, Charles F. Hermann, eds., (Beverly Hills: Sage Publication, 1978), pp. 49-51.
} 
belief-oriented. Self-oriented leaders first prioritize to maximize their own interests and not those of the state and easily changed their allegiance. Robert Jervis had observed that the tendency toward self-centered perception enables leaders to interpret their own decisions as responses to crisis conditions, while pointing to the actions of foreign rivals to justify his/her foreign policy choices. ${ }^{135}$ For self-oriented leaders, personal interests act as a motivating force. On the other hand, belief-oriented leaders tend to design foreign policies exclusively from their own perspectives without really considering crisis conditions, given the absence of a well-developed feedback mechanism. In other words, belief-oriented leaders see what they want to see. It is difficult for the belief-oriented leaders to change or shift their foreign policy orientations. Therefore they make decisions which have serious consequence for them and their countries. ${ }^{136}$ For example, both Gamsakhurdia in Georgia and Elchibey in Azerbaijan as belief-oriented leaders, without seriously considering crisis conditions of the region and within their respective countries, tried to challenge Russian influence in the region. In the end both of them were easily overthrown by their competitors with help of Russia.

Therefore, in a weak state, the leadership defines what the national interest is. One consequence of a self-oriented leader's interest in foreign policy will be increased attention of the leader to the foreign policy-making process. In other words, the motives behind the leaders' interests in foreign policy are often tied to the fear of losing political power, thus predetermining the course of action they will implement. Therefore, a weak

\footnotetext{
${ }^{135}$ Robert Jervis, Perception and Misperception in International Politics, (Princeton: Princeton University Press, 1976).

${ }^{136}$ Margaret G. Hermann and Joe D. Hermann, "International Decision Making, Leadership Matters," Foreign Policy, 1998, no. 110, pp. 124-137.
} 
state is generally one in which the leadership defines the states' interests and shapes the states' foreign policies based in terms of the leaderships' own, often personal, interests.

In conclusion, in weak states undergoing transitions in their political system, a potentially decisive factor of foreign-policy making involves a mix of the personalities of individual leaders and the conditions in which leaders make foreign policies. Thus the personalities of individual leaders strongly influence foreign policy, especially in the areas of foreign policy decision-making and implementation. Although most leaders seem to share certain personal characteristics (both self-oriented and/or belief-oriented), one must always take into account the overall situation in which the leader is acting. This notion emphasizes the role of unique personalities and their interaction as the key explanatory factor for state behavior. Finally, dramatic shifts in foreign policy often occur when there is a leadership change in a weak state. After Elchibey and Gamsakhurdia, respectively president of Azerbaijan and Georgia, were overthrown, the foreign policies of both countries considerably shifted in the early 1990 s. $^{137}$

\section{Dependent Variables}

The most basic foreign policy issue facing the leaders of weak states concerns the security of their state and themselves. Even when there has been no such direct threat to the state's survival, foreign policy often depends critically on domestic political problems, and especially on its leader's concern for domestic security and control. The best possible way for leaders of weak states to stay in power is to establish an alliance with an external power that can contribute to achieving their goals. Therefore external

\footnotetext{
${ }^{137}$ Margaret G. Hermann, "Effects of Personal Characteristics of Political Leaders on Foreign Policy," in Why Nations Act: Theoretical Perspectives for Comparative Foreign Policy Studies, Maurice A. East, et al., eds., (Beverly Hills: Sage Publication, 1978), p. 68.
} 
alliances are tools to achieve certain domestic as well as foreign policy goals in weak states. The best way to serve a state's foreign policy goals is to ally with a state or coalition that will help to achieve these goals.

\section{a. Balance of Power/Threat}

Alliance is defined as a relationship of security cooperation between two or more actors. The actors form or join in the alliance either to balance external and/or internal powers or threats. The balancing of power/threat occurs when actors join alliances to protect themselves from actors or coalitions of actors whose superior capacities could pose a threat. ${ }^{138}$ The balancing of threat occurs when the most threatening actor or coalition of actors is significantly more dangerous than the second most threatening actor or coalition of actors. ${ }^{139}$ It is rational for weak states to balance power with state(s) which has/have capabilities to affect an outcome. ${ }^{140}$ Weak states move quickly from the weak to the strong side of the balance as soon as a clear dominance in any contest can be distinguished. $^{141}$

For Stephen M. Walt, third parties generally align with the weaker state against the stronger state only if the stronger state is perceived by the third party as a threat. Walt acknowledges that 'threat dispositions' can affect balance of power politics. Threat dispositions are intentions and perceptions of actors as well as military capabilities. Walt

\footnotetext{
${ }^{138}$ Stephen M. Walt, The Origins of Alliances (Ithaca: Cornell University Press, 1987), p.18. Kenneth Waltz argues that states choose the weaker side for it is stronger side which has potential to threaten them.

${ }^{139}$ Ibid, p. 265. Stephen Walt modifies Kenneth Waltz's argument, placing emphasis on balance of threat instead of balance of power. Walt's study is based on Middle East alignment strategies from 1955 to 1979. Basically his point is states balance against threats rather than power.

${ }^{140}$ Robert L. Rothstein, The Weak in the World of the Strong: the Developing Countries in the International System (New York: Columbia University Press, 1977), p. 11.

${ }^{141}$ Rothstein, 1977, p. 11.
} 
illustrates that alliances among weak states are more directed towards balancing against threat from each other rather than threats from major powers, which they are incapable of containing. Weak states, according to Walt, balance against a major power only if they can find a major power to back them up. The Baltic states, backed by major powers in Europe and the United States, are balancing successfully to maintain independence from Russian domination. By doing so, it may be that balance of threat theory, as well as balance of power, explain alliance formation only in high insecurity environments when survival is at stake and states may indeed be forced to engage in costly balancing. ${ }^{142}$ Since survival is at stake for weak states, the notion that states constantly balance against threat is more than convincing. This may be in terms of internal balancing, where a state increases its own power domestically, or external balancing, where resources are pooled with other states for a specific purpose. ${ }^{143}$

\section{b. Bandwagoning}

Bandwagoning is a strategy to preserve basic security concerns by seeking protection from a stronger or even threatening power. ${ }^{144}$ Another possible measure of bandwagoning is support of, or lack of opposition to, the policies of the regional major power by weaker states despite the potential of these actions to threaten the interests of the latter. Ultimately in bandwagoning, the weaker actors give up a substantial degree of autonomy of action internationally in exchange for protection by the powerful. States may ally to provide themselves additional security against a threat or to advance interests

\footnotetext{
${ }^{142}$ Randall Schweller, "Bandwagoning for Profit: Bringing the Revisionist State Back In," in International Security, Summer 1994, vol. 19, no.1, pp.72-107.

${ }^{143}$ See Kenneth N. Waltz, Theory of International Politics (Reading: Addison-Wesley Pub., 1987), p. 168; John J. Mearsheimer, The Tragedy of Great Power Politics (New York: Norton, 2001), pp. 156-157.

${ }^{144}$ See Kenneth N. Waltz, 1979, p. 126; Stephen Walt, 1987, pp. 21-22; Mearsheimer, 2001, pp. 162-163.
} 
in terms of gains they can make in the international and regional system. In short, allying can be a defensive measure as well as a means to profit.

The distinction between balance of power and balance of threat is less significant since both Waltz and Walt are in agreement that weak states are more likely to bandwagon than to balance. As Walt and Randall Schweller analyze, since weak states offer little to rival coalitions and have limited effect on the outcomes of systemic changes, they are forced to bandwagon. ${ }^{145}$ Schweller points out that the "source of greatest danger to a state does not come from one side or the other but from the consequences of being on the losing side, whichever that may be. Thus power, not threat drives the state's choice." ${ }^{146}$ In laying out Walt's notion that states bandwagon for survival, Schweller deduces that alliance choices are made for gain as opposed to fear. Weak states see the potential for profit on the bandwagon, as the threat of punishment is overcome by a promise of rewards. In one case, the Armenian relationship with Russia assisted it in obtaining around one billion dollars of weapons that Armenia used in Karabagh against Azerbaijan but Armenia became economically, politically and militarily dependent on Russia. ${ }^{147}$ Balancing is a costly process that states would rather not engage in, whereas bandwagoning assumes that the stronger states will assume the greatest costs. Therefore, weaker states that cannot compete with the great power simply have to accept their lot and bandwagon with whom they can.

\footnotetext{
${ }^{145}$ Randall Schweller, "Bandwagoning for Profit: Bringing the Revisionist State Back In," International Security, Summer 1994, vol. 19, no. 1, pp. 72-107, p. 74.

${ }^{146}$ Schweller, 1994, p. 82.

${ }^{147}$ Edmund Herzig, The New Caucasus: Armenia, Azerbaijan and Georgia, (New York: Pinter, 1999), p. 67.
} 


\section{c. Omnibalancing}

Weak states' foreign policy, especially the issue surrounding "why weak states align the way they do", is not fully understood or thoroughly explained in traditional balance of power/threat and bandwagoning theories. Balance of power/threat and bandwagoning theories do not always take into account defining characteristics of weak states. Steven David's theoretical approach termed "Omnibalancing" seeks to explain what balance of power/threat and bandwagoning do not. David agrees weak states will be resistance to threats; however, leaders of weak states not only face external but internal threats and external alignment is a way to counter all threats. ${ }^{148}$

The concept of omnibalancing reinforces the central assumption of the balance of power theory by explaining weak state alignment decisions as a result of the weak state's leadership needing to counter all external and internal threats. Yet whereas balance of power theory focuses on countering threats from other states, omnibalancing considers both internal and external threats, which combination better explains weak state behavior. Further, balance of power theories work best at a systemic level where states are the unit of analysis. Threats at this level are generally external threats. However, the weak states, even influenced by systemic level changes, are mainly concerned with their on own security.

The most powerful determinants of weak state alignment involve the rational calculations of the weak state's leaders. This is due to the unstable, dangerous and violent nature of the international and domestic political environment in the weak state.

Omnibalancing has three features:

\footnotetext{
${ }^{148}$ Steven R. David, “Explaining Third World Alignment,” World Politics, January 1991, vol. 43, no. 2, pp. 233-256.
} 
1. Rather than just balance against threats or power, leaders of weak states will appease or align with secondary adversaries so that they can focus on domestic threats;

2. Omnibalancing accepts the realist notion that the world is anarchic and the use of force is always an option for state leadership;

3. Omnibalancing includes internal threats in addition to focusing on external threats and capabilities; moreover, the individual leaders of the state instead of the state itself should be used as the unit of analysis.

The nature of weak states, for instance with respect to domestic politics, is most important for their foreign policy-making processes. The most important factor is the leader's need to stay in power; ruling elites are narrowly based, weak and illegitimate and thus threatened by coups as well as by insurrection. Weak states, unlike strong states, do not have broad domestic political support. Publics do not have strong national consciousness and identification with national sub-groups is stronger than loyalty to central state; therefore, domestic politics in the weak states tend to be more anarchical than that of strong states. Therefore, anarchy, as a key point, can also be applied politics within a state, in relation to that state's position in the international system. Given this complex interaction, leaders of weak states, in trying to maximize their autonomy and security, can find an opportunity to omnibalance three different levels (domestic, regional and international). Leaders of weak states focus not only on the geopolitical threats and opportunities in the regional environment, but also on the need to maintain domestic legitimacy and the need to acquire international assistance for their leadership. ${ }^{149}$

\footnotetext{
${ }^{149}$ Stephen R. David, Choosing Sides: Alignment and Realignment in the Third World (Baltimore: Johns Hopkins University Press, 1991).
} 
In conclusion, David's omnibalancing theory, unlike those of Waltz, Walt, and Schweller, is most concerned with the internal dynamics of weak states, for instance internal threats and type of leadership. ${ }^{150}$ In addition, the significant departure of David's approach from the other theorists is that leaders of weak states may view external threats as less dangerous than internal threats. According to omnibalancing views, the "most powerful determinant of Third World alignment behavior is the rational calculation of Third World leaders as to which outside power is most likely to do whatever necessary to keep them in power." ${ }^{151}$ Internal threats directly affect these leaders' right or ability to rule; therefore, these leaders consider those threats as priority and they address their selfinterests, not necessarily their state interests, to deal with these threats.

\section{Building a Theoretical Framework to Understand Foreign Policies of Weak States}

Robert Putnam's renowned article identifying two-level games portrayed leaders as positioned between two tables of international negotiation and the pressures of domestic political forces. ${ }^{152}$ Bureaucracy and bureaucratic structure are likely to be less prominent in the foreign policies of new states because bureaucracy is weak and small, than in states like the United States, China, and Russia. In other words, the roles of large departments/ministries and the routines of administrative procedure are closely related to what happens in foreign policy in major powers but not in weak states. It is clear that the

\footnotetext{
${ }^{150}$ David provides some examples of his theory - one of which is Anwar Sadat's alignment with the US following 1973 October War. After assuming power after Nasser's death in 1970, Sadat enhanced Egypt's power with a Soviet alliance. Moscow gave Egypt record levels of military assistance - reaching a peak during the 1973 October War with Israel. However, after the war, Sadat decided to forget about this alliance and turn to the US - the backer of his chief external threat (Israel) - for support. According to David, neither ideology nor bandwagoning explains Sadat's alignment with the US. Only omnibalancing's emphasis on internal threats explains this.

${ }^{151}$ David, 1991, p. 6.

${ }^{152}$ Robert Putnam, "Diplomacy and Domestic Politics: The Logic of Two-Level Games,” International Organization, Summer 1998, pp. 427-461.
} 
insights of bureaucratic and organizational models to foreign policy-making of new weak states are limited. One of the reasons is that these states do not have stability to establish and/or manage stable bureaucratic institutions. Moreover, existing institutions in these states do not develop complex organizational routines and bargaining process with each other. Thus, because of the lack of strong bureaucratic traditions and bureaucracy for weak states, the bureaucratic-organizational model is considered of little relevance in explaining their foreign policies.

Because the state itself can not be assumed to be a unitary actor responding mainly to external threats and opportunities, the behaviors of decision-makers become one of the most important variables for weak states to understand foreign policy actions. After all, states are legal entities comprised of people. The affairs of state are conducted by ruling elites.

Therefore, in weak states, identity (state or leaders' identity), power (state strength) and interests (threats to the state/leadership) must be brought in at the domestic level as well as the international level to have a complete theory. Thus, the foreign policy of a weak state may be more immediately shaped by domestic threats or may sacrifice national interests to interests of leaderships. An understanding of the foreign policy behaviors of the state, therefore, requires analyzing how state strength affects foreign policy and the decision-making process.

I argue that the scope of a weak state's foreign policy actions depends on the type of threats, the level of external commitment as well as the characteristics of the leadership. A two-stage analysis can address some critical questions, since international threats and opportunities are often ambiguous and since domestic processes are crucial to 
explaining the foreign policy of the weak states. This model is based on the traditional understanding of the limited resources and power of weak states. My central theoretical point is to indicate that theorists have mistakenly assumed that bandwagoning, balancing and omnibalancing are opposite behaviors motivated by the goal of achieving security for the weak states. Their real difference is between balancing and bandwagoning against external threats. Omnibalancing is about internal threats. I intend to illustrate how weak states incorporate balancing and bandwagoning against external threats and omnibalancing approach against internal threats. Thus, omnibalancing is the best way to explain weak states' conditions and their leaders' policies when internal threats are considered as the most important threat for the ruling elites of the weak state.

Empirically, the traditional analysis of weak states' foreign policy-behavior has generated an ambiguous and often contradictory picture of how weak states develop their foreign policies in the international arena. Numerous theories that have been applied to a variety of countries have delivered very different explanations of the process through which weak states make foreign policy. Foreign policy analysts note that there are some common features in foreign policy approaches, which distinguish weak states from stronger states in the ways in which they conduct their foreign policies. Such common features increase if the weak states are further divided into their respective subgroups such as developing or developed; new or established; externally threatened or relatively secure.

The interconnectedness between international power and domestic policy process was at one time realism's greatest strength. If it were true that "the strong do what they will, while the weak suffer what they must," then weak states in our anarchic world 
would not have much room to maneuver in their foreign policy. It is true that the security of weak states does "suffer" from greater sensitivity and vulnerability ${ }^{153}$ as well as dependence from both the immediate regional and wider international environment. This makes it ever more important for the weak states to have a well-thought through foreign policy, using all instruments at their disposal to ensure that their security and interests are best served. Waltz argues that weak states may be least likely to follow the dictates of the international environment and balance. Due to their position with the system, weaker states will take their positions and roles in the international system for granted since their presence is insignificant with regard to international outcomes. Moreover, because major states will not focus their attention on potential threats that might come from weak states that are likely to pose little threat; the latter may face fewer external constraints. ${ }^{154}$

A theory of foreign policy should have acceptable fixed dependent variables that measure the behavior of individual states. Therefore, one of the more useful ways to construct a model of foreign policy analysis is to introduce the levels of analysis. These levels refer to the general areas from which certain foreign policy behaviors are generated. The first level refers to that which results from the impact of certain internal and external incentives. It can be conceptualized as the sources of foreign policy. The second level refers to a response to a set of incentives by leaders of states. This occurs when a state initiates a foreign policy action as well as when it reacts to the foreign policy

\footnotetext{
${ }^{153}$ Sensibility means that actors are sensitive to the other actors or developments in parts of the system. The degree of sensitivity depends on how quickly changes in one actor brings about changes in another and how great effect are. Vulnerability means that actors may be vulnerable to the effects of those changes. Vulnerability is measured by the costs imposed on a state or other actors by external events. See, for more information on sensibility and vulnerability, Robert O. Keohane and Joseph S. Nye, Power and Interdependence: World Politics in Transition, $2^{\text {nd }}$ ed., (Boston: Little, Brown, 1977).

${ }^{154}$ Colin Elman, "Horses for Courses: Why not Neorealist Theories of Foreign Policy," Security Studies, 1997, vol. 6, no. 1, p. 31.
} 
actions of another/other state(s). Thus this two-step analysis requires scholars to understand foreign policy sources and decision-making processes. ${ }^{155}$

Some scholars argue that internal factors (domestic politics, domestic institutional choices, etc :...) are more important than external factors (international and regional systems, etc :...) in explaining weak state foreign policy. ${ }^{156}$ For instance, Miriam Elman suggests that domestic institutions play important roles because they shape and provide possible options which a government implements. Moreover, Sasha Baillie brings a different view on weak states' foreign policy-making processes and behaviors. She claims that weak states' foreign policies are dependent on three features: legacy of the past, the decision-making process, and institutional framework. ${ }^{157}$

Thus, the weaker the state, the more likely it will respond to external challenges and balance against rising hegemons. Because of their diminished capabilities relative to others, weak states lack a margin for time and error: they must be closely integrated and linked to the external environment because if they isolate themselves, their survival will be at stake and costs of being exploited high, as was true of Gamsakhurdia's Georgia in 1991. Therefore, because of the nature of the threat, governments of weak states experiencing internal threats will have different foreign policy behaviors to end internal threats. $^{158}$

\footnotetext{
${ }^{155}$ Elman, 1997, p. 32.

${ }^{156}$ Miriam F. Elman, "The Foreign Policies of Small States: Challenging Neorealism in Its Own Backyard.” British Journal of Political Science, 1995, vol. 25, no. 2, pp. 171-217.

${ }^{157}$ Sasha Baillie, “A Theory of Small State Influence in the European Union.” Journal of International Relations and Development, August 1998, pp. 195-219.

${ }^{158}$ The threat could be based on internal power struggles, like in Georgia, and/or ethnic minority refused to recognize and rebel against to the central government or ethnic minority desire to establish its own state or
} 
Another factor to explain foreign-policy behavior is beliefs and interests of leaders. The leaders can easily exploit the linkage between their own security and that of the state in order to increase their leverage over domestic politics. For instance, both Shevardnadze and Aliyev became the leaders of their countries after political crises and coups in the early 1990s. They accumulated power and authority and became a sole authority in their respective countries. In conclusion, by requesting dealing with threats, leaders can increase their powers and make use of these powers against domestic opponents. $^{159}$

\section{Hypotheses and Arguments}

Internal factors exhibited in my dissertation focus on the strength of the state and the role of leadership. External factors focus on external assistance to the weak state. Threats can be both internal and external in nature, according to where it comes from and level of its intensity. The foreign policy of a state may be designed to ease tensions on internal structures.

In this section, I will suggest that both the external factor (degree of commitment of a global or regional power) and the internal factor (strength of the state) are critical independent variables affecting state foreign policy-behavior. Thus, the study of foreign policy serves as a bridge by analyzing the impact of both external and internal politics on states' relations with each other.

\footnotetext{
integrate/join a state which is established and governed by their kin, like Karabagh Armenians in Azerbaijan.

${ }^{159}$ Barry Buzan, People, States, and Fear: An Agenda for International Security Studies in the Post-Cold War Era, (Brighton: Wheatsheaf Books, 1983), p. 89.
} 
The role of leadership is variably linked with the foreign policy-making environment and foreign policy-behavior. Leaders perceive reality differently because of differing "belief systems." In this view, the perceptions and actions of leaders are not determined by system structure; instead policies flow from the ways in which leaders "construct" reality. There are two types of leadership in the post-Soviet environment: self-interest-oriented leadership and belief-oriented or nationalist leadership. For selfinterest-oriented leadership, the most important function of foreign policy is to keep the leadership in power. For the belief-oriented leadership, the most important function of foreign policy is to accomplish certain goals. ${ }^{160}$ Thus, a state's weakness gives leverage to leaders of weak states to define state interests and shape foreign policy based on his personal interests and beliefs.

Belief-oriented leaders may attempt to take steps to achieve their goals. That way they can legitimize their authority. Belief-oriented leaders may have an interest in participating in the international community on their own terms and without having a dependent relationship with any other country.

Nationalism as a part of people's beliefs and values affects how, and in what ways, a state defines foreign policy in pursuit of its core interests. Nationalists, therefore, tend to glorify their own nations and even their superiority. As a belief, nationalism represents one view of the world. Believing, as nationalists do, that his nation is good and that other nations produce the problems, their cognitive map can divide two groups: his nation and outsiders. The outsiders are considered as enemies or potential threats.

\footnotetext{
${ }^{160}$ Goals are related with belief of leaders, for instance, goal of nationalistic leaders, like Gamsakhurdia and Elchibey, which recently established independent states, is to push influence of former imperial power, Russia, away from their countries and increase roles of ethnic Georgians and Azeris in political arena.
} 
Therefore, nationalists are by definition ready for conflict with enemies. ${ }^{161}$ Therefore, a leader's beliefs provide him with a direction for charting his foreign policy behavior.

On the other hand, the foreign policy choices of self-oriented leaders are influenced by their experiences and immediate concerns. Self-oriented leaders assign the most loyal elements, often members of their tribes or ethnic groups, to the government's institutions. Above all, the most trusted members are assigned to the most important positions such as in military and in strategic business, which are potentially most threatening to state leaders and exercising the most control in society. Thus, self-oriented leaders perceive domestic and international pressures and try to grasp the nature of the balancing act both in the internal and external political environment.

As the Soviet internal empire has become the 'near abroad', so has the imperial order been replaced by the anarchical order. Fifteen new states emerged. Each state has established its state institutions. Those who control decision-making power in the state, as leaders and members of the ruling elite, have their own interests and beliefs. Therefore, leaders of the post-Soviet states, in order to secure their interests and beliefs, as well as the sovereignty and independency of their states, have to choose the best possible option: to be neutral or to build and/or maintain an alliance with other actors/states. ${ }^{162}$ All postSoviet states, save Turkmenistan, have rejected different forms of neutrality, and have chosen three different types of alliance as their foreign policy options: balance of power/threat, bandwagoning and omnibalancing.

\footnotetext{
${ }^{161}$ Margaret G. Hermann, "Effects of Personal Characteristics of Political Leaders on Foreign Policy," in Why Nations Act: Theoretical Perspectives for Comparative Foreign Policy Studies, Maurice A. East, Stephen A. Salmore and Charles F. Hermann, eds., (Beverly Hills: Sage Publication, 1978), p. 66.

${ }^{162}$ Mehdi Mozaffari, “'”The CIS Southern Belt: A New Security System,” in Security Politics in Commonwealth of Independent States: Southern Belt, Mehdi Mozaffari, ed., (London: Palgrave Macmillan, 1997), pp. 3-34.
} 
The framework for these relationships is represented schematically below:

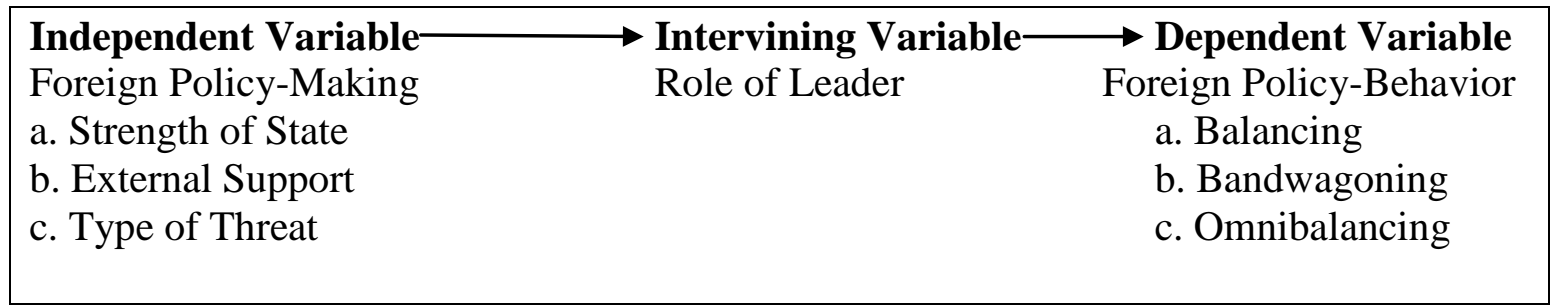

The other hypotheses are sub-hypotheses which are essentially related to the main hypotheses:

\begin{tabular}{|l|}
\hline \multicolumn{1}{|c|}{ External Threat> Internal Threat for Weak States } \\
\hline Hypothesis 1. If the external commitment is strong, and if the leadership of the state is \\
self-interest-oriented, state foreign policy is likely to be balancing. \\
\hline Hypothesis 2. If the external commitment is strong, and if the leadership of the state is \\
nationalist-oriented, state foreign policy is likely to be balancing. \\
\hline Hypothesis 3. If the external commitment is weak, and if the leadership of the state is \\
self-interest-oriented, state foreign policy is likely to be bandwagoning. \\
\hline Hypothesis 4. If the external commitment is weak, and if the leadership of the state is \\
nationalist-oriented, state foreign policy is likely to be balancing.
\end{tabular}

The first option for the post-Soviet states is balance of power and of threat. The balancing of power occurs when actors join alliances to protect themselves from actors or coalitions of actors whose superior resources/capacities could pose a threat. The balance of threat occurs when the most threatening actor or coalition of actors is significantly more dangerous than the second most threatening actor or coalition of actors. 
The second option for the post-Soviet states is bandwagoning. Walt attempted to understand when states bandwagon. He concluded that the plausibility for bandwagoning is high if a state is weak and if there are no available supporters or allies. By bandwagoning the weak states hope to moderate any possible aggressive intentions on the part of strong state(s) and to secure the various benefits of the strong state's support. Both conditions were in place in the Caucasus during the early 1990's. Armenia, Azerbaijan and Georgia were all economically and militarily weak, with no available allies or support against Russia. For instance, by bandwagoning with Russia, Armenia moderates any possible aggressive intentions of Russia and secures the various benefits of Russian support in Armenian relations vis-à-vis the other Caucasian states, i.e., Azerbaijan and Georgia.

The most important variable when external threats are more prominent than internal threats is the level of external commitment. If the level of external commitment is high, then the type of leadership becomes insignificant. Both self-oriented and belieforiented leaders cooperate with external major powers to balance the state which threatens them. If the level of external commitment is low, under conditions of prominent external threat, leaders choose foreign policy options according to the orientations of their beliefs and interests. Under this condition, self-interest oriented leaders choose bandwagoning policy. In doing so, they secure themselves against internal threats by ignoring secondary external threats. However, belief-oriented leaders look for other forms of external power to balance against states who threaten their states. Even if the external commitment is weak, they look for assistance from another major power. The results of these policies are mostly the isolation of the weak state and ultimately 
nationalist-oriented leaders being overthrown by externally aided internal forces. For instance, Gamsakhurdia in Georgia and Elchibey in Azerbaijan were overthrown by externally aided internal forces when they had low assistance from major powers.

\section{Internal Threat > External Threat for Weak States}

Hypothesis 5: If the external commitment is strong, and if the leadership of the state is self-interest-oriented, state foreign policy is likely to be omnibalancing.

Hypothesis 6: If external commitment is strong, and if the leadership of the state is nationalist-oriented, state foreign policy is likely to be balancing.

Hypothesis 7: If the external commitment is weak, and if the leadership of the state is self-interest-oriented, state foreign policy is likely to be omnibalancing.

Hypothesis 8: If the external commitment is weak, and if the leadership of the state is nationalist-oriented, state foreign policy is likely to be balancing.

Under a strong internal threat, balance of power theory's emphasis on the state's need to align in ways that guarantee its survival appear to be contradicted by weak state leaders' aligning in ways that guarantee their personal survival. Most importantly, by excluding internal threats as a factor in alignment, balance of power theory seemingly ignores the most significant factor that determines why leaders align as they do. Other theories of alignment such as bandwagoning are even more inadequate in explaining the alignment decisions of the leaders in the case studies under these conditions.

If an internal threat is more serious than an external one, then the role of external commitment becomes important variable. External commitments are used by selforiented leaders to balance against internal threats. Because of instability, the dangerous 
nature of politics in weak states; the balance-of-power theory needs substantial modification before it can be applied to weak states. Omnibalancing theory argues the most powerful determinant of weak states foreign policy-behavior is the calculation of weak states leaders. Leaders of weak state are most likely to do what is necessary to keep them in power. However, for belief-oriented, especially nationalist-oriented, leaders the main threat is usually external in nature. For instance, even when they have an internal threat challenging their leaderships and the former imperial power can assist them, they will not shift their foreign policy and ask help from the imperial center, such as Gamsakhurdia and Elchibey did.

Omnibalancing theory repairs the defects in balance of power theory by focusing on the efforts of weak states' leaders to ensure their political survival rather than focusing on efforts to ensure the state's survival and by including internal as well as external threats to the leadership and the state, as opposed to external threats alone, in explaining the decision to align. ${ }^{163}$ For instance, the stakes for domestic politics are extremely high, sometimes leading to the death of a deposed leader or losing power for the nationalistoriented leaders. For example, the first president of Georgia, Zviad Gamsarkhurdia, died one year after he was deposed in 1993; former Azerbaijani President Elchibey lost his seat in 1993 and became an unimportant player in Azerbaijani politics until he died in 1998. Thus, the theory of omnibalancing allows for greater explanatory power in Caucasus weak states' foreign policy orientation.

\section{Applying Foreign Policy Models to the Caucasus States}

It should be stressed that within the Caucasus states, common conditions of domestic weakness have influenced the function of foreign policy; however, such

\footnotetext{
${ }^{163}$ Stephen R. David, Choosing Sides: Alignment and Realignment in the Third World, 1991, p. 1.
} 
domestic conditions have not necessarily ended up in similar governmental responses. Their foreign policies and different alliance with major powers in the region have been influenced by the ruling elites. In other words, the use of foreign policy to serve domestic needs, in order to repair or contain domestic divisions and also to maintain the leadership, is a common feature in the Caucasus but different policies implemented to reach the same goal, i.e., the using of foreign policy in order to maintain internal political order and possess a critical external support for one's domestic position. Indeed, many external relationships established by governments in the Caucasus have been reflected, above all, as access to a source of balancing power to contain internal challenges and threats.

In particular, foreign policy options frequently rise out of a need to strengthen the domestic political order where that order is affected by ethnic minorities who possess an affinity with either a neighboring regional state or a major power. There are minorities in different Caucasus states who are very active politically. Therefore, throughout the Caucasus, separatism has been widespread and matched by irredentist claims of varying intensity. These have been of considerable relevance in the foreign policies of states resisting such claims.

However, the issues of war and peace in the Caucasus have never been decided solely by domestic factors. Once at the crossroads of empires and conquering peoples, the Caucasus states remain at the geographic point of competition between major powers and potential turmoil. In short, external factors are also critical to any analysis of the postSoviet Caucasus foreign policies. 
One underlying feature of the early years of Caucasus states is that nationalist movements played central roles in their domestic political systems. ${ }^{164}$ In Armenia, Azerbaijan, and Georgia the nationalist dissidents and oppositions of the Soviet regime took control of the Caucasus states as early as 1990. However, In Azerbaijan and Georgia, the former Communist Party of the Soviet Union (CPSU) Politburo members and former Communist Part leaders, Haydar Aliyev and Eduard Shevardnadze returned to power in their respective countries as early as 1992. For example, in 1992 Georgia was the first state in the region to return its former Communists to power.

One of the few obvious points to emerge from the chaos of the early independent years in the Caucasus has been the overwhelming political superiority of leaders who control the state mechanism over any other organized source of power within the political system. For this reason oppositions are easily suppressed and governments are generally overthrown by a quick putsch to seize state power rather than by a general mobilization of support in the country as a whole.

The presidential offices in the Caucasus states combine the roles of chief of government and chief of state. As chief of government, the president is called on to act as a partisan political leader. As chief of state, the president is the living symbol of national unity and is not subject to serious institutionalized constraints, unlike those facing the

\footnotetext{
${ }^{164}$ See, Ian Bremmer and Ray Taras, eds., Nation and Politics in the Soviet Successor States (Cambridge: Cambridge University Press, 1993); Roman Szporluk, ed., National Identity and Ethnicity in Russia and the New States of Eurasia (Armonk: M.E.Sharpe, 1994); Leokadia Brobizheva, Rose Gottemoeller, and Catherine M. Kelleher, eds., Ethnic Conflict in the Post-Soviet World: Case Studies and Analysis (Armonk: M.E.Sharpe, 1996); Ronald G. Suny, Transcaucasia, Nationalism, and Social Change: Essays in the History of Armenia, Azerbaijan, and Georgia (Ann Arbor: The University of Michigan Press, 1996; Ian Bremmer and Ray Taras, eds., New States New Politics: Building the Post-Soviet Nations (Cambridge: Cambridge University Press, 1997); Karen Dawisha and Bruce Parrott, eds., Conflict, Cleavage, and Change in Central Asia and the Caucasus (Cambridge: Cambridge University Press, 1997); Barnett R. Rubin and Jack Synder, Post-Soviet Political Order: Conflict and State Building (London: Routledge, 1998); and Mark R.

Beissinger and Crawford Young, eds., Beyond State Crisis?: Postcolonial Africa and Post-Soviet Eurasia in Comparative Perspective (Washington, D.C.: Woodrow Wilson Center Press, 2002).
} 
United States president from Congress and the judiciary. In weak states, generally the president and his entourage control both legislative and judiciary, as well as all executive institutions. As a result, the immediate decision-making setting of foreign policy is highly personalized. It is not surprising that foreign policies are sometimes a tool for holding onto power. ${ }^{165}$ In other words, within the states of the Caucasus, the domain of foreign policy is normally preserved for a few trusted individuals and in some cases, effective decisions are made only by one leader. Such practices have become increasingly common within the region. For instance, Shevardnadze and Aliyev were two leaders who obviously exercised considerable personal authority in the making of foreign policy decisions without any significant degree of institutional, political, or popular control over their decisions and actions.

Furthermore, it should also be stated that where foreign policy has been identified with a particular leadership, there has been a significant correlation in the Caucasus experience between change of that leadership and substantive foreign policy change. When the change in political order has been involving the total replacement of ruling elites, the degree of changes in foreign policy can be fairly significant. Therefore, personality, or to be more precise, personal leadership, is undoubtedly important in the actual making of foreign policy among the states of Caucasus.

However, while individual leadership may be expressed in distinctive styles, any essential discontinuity of foreign policy would arise primarily from changes in the domestic political order rather than from significant alterations in the external environment. For instance, in the second half of the 1990s, the Caucasus became the focus of the competing interests of major powers; this development provided

\footnotetext{
${ }^{165}$ Herzig, 1999, pp. 26-31.
} 
opportunities for self-interest oriented leaders like Shevardnadze and Aliyev to shift their foreign policy orientation from the imperial center to other major players in the region. In these circumstances when the region has assumed more significance in global terms, foreign policy behavior has been linked more with external politics. Moreover, the opposite is also true. When the region has assumed a lesser significance in international arena, foreign policy behavior has been linked more with domestic politics.

In comparison to the Baltic states, which had undergone statehood experiences between the First and Second World Wars, the Caucasus statehood experience was in effect three years (1918-1921), when the Russian Tsarist Empire collapsed and the Bolsheviks had yet to establish their authority in the region. Therefore, their states were imperial artifacts, their borders were artificially created, and their policies reflective of tribal, clan, or kin affiliations more than affinity with characteristics of a nation-state. Therefore, late state formation and the weakness of nation building process are substantial influences upon both the internal stability of the Caucasus states and the patterns of relations between these states and their neighbors as well as their relations with the imperial center.

Moreover, since independence, the post-Soviet Caucasus states have been burdened by the very same problems that other nation-states face: i.e., sub-national regions defined by ethnic or economic grounds that do not accept the sovereignty of the central state. Lastly, there are minority nationalities claiming territorial rights. One of the reasons is that both the administrative structure and borders of the Caucasus states were determined in the Stalinist era. Therefore, in the Caucasus states' boundaries and ethnic 
composition lacked correspondence with titular nationalities and territorial integrity of the Caucasus states were challenged by ethnic minorities in the early 1990s. ${ }^{166}$

Therefore, analyzing the nation and state-building process is, for several reasons, crucial in understanding the foreign policy-behavior of the Caucasus states. First, whatever the constraints put on states by their systemic environment, there is not only one possible response to it. While all three states in the Caucasus have suffered violent conflicts and the uprooting of the old political system, some of them have challenged the status quo, others supported it and sometimes the same state changed from supporter to challenger. For instance, in Armenia the nationalist opposition took control of the republic as early as 1990 and quickly established a stable government structure, accepted the regional status quo and accepted Russian influence in the region. On the other hand, Azerbaijan and Georgia, after Aliyev and Shevardnadze came to power, shifted their foreign policy orientation from challenging the status quo to accepting the status quo in the region in the early 1990 s. $^{167}$

Second, the Caucasus has arguably been one of the regions most affected by ethnic conflicts; even compared to the Balkans, the Caucasus region is more ethnically, nationally and culturally divided. The conflicts of the Caucasus, despite the unique circumstances and conditions of each, display remarkable similarities in their roots and immediate causes. The four major conflicts- Karabagh, South Ossetia, Abkhazia and Chechnya- are all characterized by ethno/national-based autonomous regions of the

\footnotetext{
${ }^{166}$ Graham Smith et all, Nation-Building in the Post-Soviet Borderlands: The Politics of National Identities (Cambridge: Cambridge University Press, 1998), pp. 64-65.

${ }^{167}$ Svante E. Cornell, Small Nations and Great Powers: A Study of Ethnopolitical Conflict in the Caucasus (Surrey: Curzon, 2001), pp. 392-393.
} 
Soviet era revolting against their respective central governments during and after the fall of the Soviet Union. ${ }^{168}$ This ethnic diversity, so characteristic of the Caucasus, when added to the general characteristics of weak states such as economic underdevelopment and limited external assistance, frames the orientation and behavior of foreign policy. For the Caucasus states, the primary concern has not changed; consequently, the principle 'foreign policy begins at home' is relevant to understand and explain the Caucasus states' foreign policy orientation.

Finally, the states of the Caucasus are largely treated in the same manner in international politics. Because of the large asymmetry of power between Russia and the Caucasus states, Armenia, Azerbaijan and Georgia were recognized as parts of the Russian sphere of influence and interest, although all states sought to increase their independence from Russia in the 1990s. From a Russian point of view, they are the southern 'Near Abroad' or part of the Russian “Monroe Doctrine.” For Turkey and Iran they are the central link for the Silk Road. By most other major powers, they are commonly considered as the southern part of the former Soviet Union, which is a sphere of influence region of Russia. ${ }^{169}$ Therefore, Armenian, Azerbaijani and Georgian foreign policies present interesting cases in contemporary Eurasian politics.

Armenia, Azerbaijan and Georgia shared relational characteristics with respect to Russia. They are geographically small with marginal to non-existent military strength relative to Russia. They have weak, insecure state structures and identities. They are highly dependent upon Russia for economic survival. While the Caucasus states began to

\footnotetext{
${ }^{168}$ Cornell, 2001, p. 17.

${ }^{169}$ Charles W. Walldrof, Small States in International Affairs: Russian Relations with Azerbaijan and Tajikistan 1993-4, Unpublished Master Thesis, University of Virginia, 1996.
} 
build their statehood, Azerbaijan and Georgia were devastated by conflicts, in Karabagh and Abkhazia, respectively. Moreover, the domestic conflicts of these countries resulted in long-lasting political and economic crisis that was unparalleled in the former Soviet region.

Armenia, Azerbaijan and Georgia represent the type of weak state that continues to struggle in completing the state-building process while at the same time dealing with internal and external conflicts. Attention will therefore be given to the insecurity produced by these conflicts and the role that the regional actors play in conflicts. Due to the threats related to security and major economic problems, the important question for the Caucasus leaders is how to secure (1) their own leadership and then (2) the survival of their states. Most of the energy in Georgian and Azerbaijani foreign policy has been spent on internationalizing the conflicts, thereby gaining support in the international community and from the other major powers during the second half of 1990s. For instance, Georgian foreign policy is dominated by one particular issue portraying Russia as an essential threat to the existence of Georgian state. The identity of the current Georgia regime is very much built on this premise of rejection of the legacy of the past (Tsarist and Soviet). Therefore, the foreign policies of these newly independent weak states are consequently dominated by the question of the building state.

Russia has reconstituted an ability to intervene militarily and impose economic sanctions in the region, thereby reviving Russian influence in the Caucasus states after the initial years of their independence. Russian interests include: a desire to control the vast oil deposits located in the surrounding area of the Caspian Sea and profit from their transport to international markets; as well as a desire to protect Russians beyond Russia's 
borders. ${ }^{170}$ Russian governments have thus continued to exert influence on former Soviet republics of the Caucasus, in spite of Western reaction to Russian policies in the 'Near Abroad'. While all these factors played a role in the formulation of various Russian policies on the region, Russian perceptions of regional security threats to Russian interests is the most important variable to explain Russian policies. ${ }^{171}$ As Russia's role in shaping the conflicts indicates, the significance of the Russian influence was considerable in the region because the Caucasus states have been characterized by weak regimes, poorly-integrated societies, and very small militaries in the 1990s; therefore, they are still vulnerable to the influence of the regional power and ex-imperial center. For instance, as the civil war in Georgia demonstrates, the ruling elites of the Caucasus states are sometimes forced to ask for assistance from the former imperial power to support their territorial integrity and protect their leaderships against internal and external enemies.

On the one hand, the early Azerbaijani and Georgian nationalist-oriented leaders, Elchibey and Gamsakhurdia, perceived Russia as the main threat to the survival of their regimes and states. Gamsakhurdia refused to make Georgia a part of the Commonwealth of Independent States (CIS), while Elchibey withdrew Azerbaijan from the CIS. In the case of Azerbaijan during Elchibey's regime, Turkey replaced Russia as Elchibey’s regime protector. On the other hand, Armenian leaders have linked their national and international security needs with cooperative political and military relationships with Russia.

\footnotetext{
${ }^{170}$ Rajan Menon, “After Empire: Russia and the Southern 'Near Abroad',"in The New Russian Foreign Policy, Michael Mandelbaum, ed., (New York: Council on Foreign Relations, 1998), p. 103.

${ }^{171}$ Leila Alieva, Reshaping Eurasia: Foreign Policy Strategies and Leadership Assets in the Post-Soviet South Caucasus, Winter 2000, http://repositories.cdlib.org/iseees/bps/, p. 6.
} 
Russian foreign policy in the Caucasus aimed toward weakening those Caucasus states and their leaders who sought to balance Russian influence and seek assistance from other major powers. Russia was unwilling to see the post-Soviet Caucasus states escape its "sphere of influence." It sought to weaken these states and leaders through coercive policies. Despite Russia’s weakness, Russia was geographically much larger, and inherited institutions and resources that were much more powerful than those of the Caucasus states. Russia also inherited Tsarist and Soviet legacies of a dominant state status in the Caucasus. Specifically, the experience of the political and security institutions during the Russian and Soviet empires provided necessary skills for the Russian involvement to the Caucasus states. ${ }^{172}$ Despite this, the cases of ArmenianRussian, Azerbaijani-Russian and Georgian-Russian relations are significant examples of the patterns of influence that have been common across the Caucasus and Central Asia in the 1990s. Against a wave of Russian demands, the governments of Azerbaijan and Georgia avoided Russian domination and sought the support of major powers to balance Russian influence in the region.

Therefore, the Caucasus states' foreign policies are, using Rajan Menon's turn of phrase, 'in the shadow of the bear. ${ }^{, 173}$ Russia foresaw security issues in the Caucasus as a means for manipulation or expansion of its influence in what it considered its "near abroad" or sphere of influence. In the early 1990s, there were two trends of the Caucasus states' foreign policies vis-à-vis Russia. First, the Caucasus states' foreign policies were based not on balancing against Russia but rather to obtain Russian support against

\footnotetext{
${ }^{172}$ Alieva, 2000, p. 2.

${ }^{173}$ Rajan Menon, "In the Shadow of the Bear: Security in Post-Soviet Central Asia," International Security, Summer 1995, vol. 20, no. 1, pp. 149-181.
} 
internal opponents or rival neighboring states. Secondly, the Caucasus states tried to find another major power(s) to balance Russian influence in the region.

In conclusion, to explain the foreign policies of the Caucasus states, we must understand the broad effects of the collapse of the Soviet Union, which changed and reshaped security and economic patterns in the region. The emergence of these new patterns was not just the expected result of the disintegration of the Soviet empire. The high degree of uncertainty that followed the collapse allowed quite a wide range of alternative developments throughout the post-Soviet space. One could say that the political behavior of the South Caucasus leaders was based on making use of competing regional and outside interests. ${ }^{174}$

There are two reasons why foreign policies that defined individual leadership policies assumed such importance in the Caucasus in the early 1990s. First, the external major powers generally neglected and ignored the development of the post-Soviet states. The post-Soviet foreign policies of the major powers were characterized by "wait-andsee" tactics. Therefore, at the beginning, the Caucasus countries did not enjoy substantial political support of other major powers. For example, the United States policy focused on Russia at the expense of the former Soviet Republics. As a result, the maneuvers of the post-Soviet Caucasus leaders were seriously undermined by the other major powers policies towards Caucasus states.

Thus, my analysis will contribute to explanations of new and weak state behavior, in particular, disputes between realist and domestic level theories that seek to explain factors influencing this behavior. The analysis of post-Soviet Caucasus international relations supports the explanation provided by these theories that stress the inter-

${ }^{174}$ Alieva, 2000, p. 12. 
relationship of domestic and foreign factors at different stages of state building and conditions of the international environment. In the early stages of a state's history, not only the international or security environment but also domestic politics and type of leadership are the primary factors which affect state institutions. 


\section{Chapter III}

\section{Introduction}

An effective way of understanding the foreign policy process is to identify the levels of analysis. These levels refer to general areas from which certain foreign policy behaviors are generated in a state, and at which foreign relations occur between states. With the recognition that foreign policy-behavior occurs at the state and interstate levels, we can differentiate between two distinct approaches to explain the foreign policy process of a state: 1) the role of certain internal factors and actors; and 2) the role of external factors and actors. Such approaches are needed to identify as the sources of foreign policy.

When a state decides to respond to a set of factors (location, military capability, economic power, natural resource, etc.) its leaders as actors take certain actions. This especially occurs when a state is initiating a foreign policy action as well as responding to the actions of other states. One needs first to conceptualize a mechanism how to initiate foreign policy action and how to respond another state's action, and then conduct inquiries into the internal and external sources of foreign policy decision-making. ${ }^{175}$

Therefore, there are primarily two distinct sources for foreign policy: internal and external sources. Internal sources refer to domestic factors that are helpful for generating a foreign policy approach. Among these are the individual leaders, internal economic and political factors which contribute to the articulation, and adoption of a specific foreign policy approach. External sources refer to areas that arise beyond a state's boundaries

\footnotetext{
${ }^{175}$ Jonathan Wilkenfeld, et al., Foreign Policy Behavior: The Interstate Behavior Analysis Model (Beverly Hills: Sage Publications, 1980), p. 21.
} 
such as regional political settings and international system and also lead to specific foreign policy choices.

The factors influencing foreign policy-making processes of the Caucasus states have evolved differently from strong states like Russia and the United States. These factors are political instability, weak state institutions, power struggles among different political groups to control the states, and economic condition of these states. Such factors have shaped the orientation and implications of foreign policy in the Caucasus states. In addition, changes in the international system have created new regional environments. In doing so, the increased level of international involvement in the region creates new opportunities and restrictions to the foreign policies of these newly independent states. For example, the Azerbaijani and Georgian governments have struggled to control, govern, and contain the political elites and ethnic separatists' groups within their borders.

Moreover, conflicts between central governments and separatist groups had escalated into wars such as in both Georgia and Azerbaijan in the early 1990s. Therefore, Azerbaijan and Georgia were dealing with internal threats to their governments. These internal threats shaped their foreign policy approaches in the 1990s. However, Armenia perceives the main threat as the external one. The Armenian government recognizes Turkey, for historical reasons, and Azerbaijan, for the Karabagh problem, as its main external threats. Thus, for the Azerbaijani and Georgian governments, the main threat was an internal one; for the Armenian government the main threat was and still is external one.

Chapter III will examine the background of the three independent Caucasus states, specifically investigating their legacies of the past and what kinds of socio-political 
structural changes happened in order to gain a better understanding of how their respective foreign policy-making processes have developed. It is clear that geography, history, and political culture play significant roles in creating a legacy. The construction of state legacies is important in that they affect the strength of state institutions, political environments, and their relations with other states. For example, both the Soviet and Russian legacies remain important in the Caucasus states because of their shared identity and experiences within the Soviet Union. This chapter will also examine both the structures of states and actors that influence the foreign policy process. As William Faulkner perfectly put: "the Past is never dead. It's not even past." I will be asking the questions, "How have the legacy of the past, current state structures and ruling elites of the Caucasus states contributed to shaping foreign policy options?" and, "To what extent were leaders of these states able to direct their state relations with Russia and other important external players, for instance, the United States and other regional powers during the 1990s?" The main task of this section will be to analyze the impact of the factors and actors within the framework of selected case studies.

\section{The Caucasus: General}

\section{a. Strength of States}

\section{Political Succession}

The Caucasus states experienced varying levels of authoritarianism during the 1990s. The authoritarian characteristics of these states prevented the growth of autonomous interest groups and parties, while at the same time undermining a sense of political competition and institutionalization of political succession. For this reason, politics inside the authoritarian regimes became mostly personalized and revolved around 
the leadership. Leaders' political decisions vastly prevented the development of stable state structures and institutions because the authoritarian leaders were not sure about their own political future and implemented policies simply to stay in power. Therefore, the authoritarian leaders have used their influence and powers to prevent the development of large concentrations of political control outside their leadership.

It is clear that strong state institutions have the capability of creating threats to authoritarian leadership. When strong state institutions are needed for the survival of the regime, the leaders have varied their approaches and policies. For example, the leaders strengthen their political powers by limiting the ability of state institutions, or using state institutions balancing against one another. ${ }^{176}$ In this way, the authoritarian leaders create spaces in order to balance and accommodate political and economic institutions and their activities for their own self-benefits. Therefore, the survival of weak states and their leaders largely depends upon a leaders' ability to be in control and command of the state institutions and structures. For instance, the appointment of high official positions in most weak states is on the basis of loyalty or their ethnic affiliation with the leader. This may affect institutional operations and their ability to accomplish certain tasks. ${ }^{177}$ Secondly, and quite importantly, the frequent firing of high-level government officials can have a destructive effect on establishing and creating a stable atmosphere for a smooth political succession and continuity of state institutions.

Because of the weakness of political institutions and accumulation of power in the hands of the presidents, political succession became a problematic issue for the Caucasus

\footnotetext{
${ }^{176}$ Joe S. Migdal, Strong Society and Weak States, (Princeton: Princeton University Press, 1988), p. 214.

${ }^{177}$ Migdal, 1988, p. 217.
} 
states. The transition of power tends to occur without following legitimate constitutional paths. For instance, in Armenia in 1998, Azerbaijan in 1992 and 1993, Georgia in 1992 and 2003, political succession happened without elections, basically first with coups unseating incumbent presidents and installing new ones and then, in order to provide legitimacy to the new presidents, holding presidential elections. But these presidential elections generally were not fair and free according to international standards. ${ }^{178}$ Therefore, the functions of these elections were only to provide a popular legitimacy to the new presidents.

Armenia's constitution was adopted in 1994, while Georgia's and Azerbaijan's were adopted a year later. Each state's constitution outlined their governance structures and distribution of responsibilities between the parliaments and governments as well as relations among legislative, judicial and executive branches. The constitutions of the Caucasus states are similar to the Russian constitution. Therefore, the constitutions of the Caucasus states are presidential in their nature, meaning that they grant the presidents considerable powers. Moreover, according to the constitutions of the Caucasus states, presidents are elected by direct vote. Thus, the Caucasus model grants the presidents superiority and dominance over the parliaments and judiciaries.

\section{Political Uniformity}

Historically, when the Bolsheviks seized power in the Caucasus, they characterized the Caucasus people as strongly clinging to traditional customs, clan ties,

\footnotetext{
${ }^{178}$ Svante E. Cornell, "Democratization Falters in Azerbaijan," Journal of Democracy, April 2001, vol. 12, no. 2, pp. 118-131 and Charles H. Fairbanks, "Georgia's Rose Revolution," Journal of Democracy, April 2004, vol. 15, no. 2, pp. 110-124. Presidential elections were held Armenia in 1991, 1996, 1998, 2003 , 2008, in Georgia in 1991, 1995, 2000, 2004, 2008, and in Azerbaijan in 1992, 1993, 1998, 2003, scheduled October 2008. Additional information can find at the OSCE/ODIHR (Office for Democratic Institutions and Human Rights) webpage, www.osce.org/odhir_elections/14207.html, and International Foundation for Electoral Systems webpage, www.electionguide.org/
} 
religious beliefs, distinct ethnic identities, and patriarchal family relations. The Soviet Union's modernizing projects forced the traditional institutions of Caucasus to adopt more centralizing and collective policies. These policies continued until the late $1980 \mathrm{~s} .{ }^{179}$

However, the federal form of the Soviet constitution also granted the union republics of Georgia, Azerbaijan, and Armenia national assemblies, administrative bureaucracies, foreign and interior ministries, as well as regional and local administrative bodies. These structures resemble the state institutions of sovereign states. Although all union republics of the Soviet Union had state institutions comparable to those possessed by independent states real power lay in the hands of Communist Party leaderships and generally in the hands of Soviet Union's Politburo members and bureaucrats in Moscow.

Therefore, from the late 1980s to the second half of the 1990s, the political leaderships of all three Caucasus republics had maintained the political and administrative structures installed from the Soviet period. Nevertheless, these state institutions inherited from the Soviet Union did not provide the Caucasus states the necessary tools to maintain basic levels of law and order in the beginning of the 1990s. This is largely because the state institutions established by the Soviet era did not represent the real distribution of power in those states. The power center was the Communist Party and its networks. When the Soviet Communist Party collapsed, the majority of state institutions became obsolete. Thus the weak state institutions inherited from the Soviet system by the Caucasus republics led to a concentration of power in their presidents. For that reason, throughout the Caucasus regions, authoritarian leaders have

\footnotetext{
${ }^{179}$ Ronald G. Suny, The Revenge of the Past: Nationalism, Revolution, and the Collapse of the Soviet Union, (Stanford: Stanford University Press, 1993), pp. 113-117.
} 
consolidated their authority without any real political opposition by restricting pluralism and political party development.

Lastly, in Azerbaijan and Georgia, the lack of a basic national consensus on the definition of nationhood and functioning of political institutions has led to the oppression of political opposition movements and parties. Moreover, it led to internal fighting between different political and ethnic groups, and coup d'états against governments and presidents. In addition to these, the Caucasus states (especially Azerbaijan and Georgia) lacked one of the most important basic features of sovereign states, i.e., regular security forces (army and police) fully loyal to the states, not individuals or ethnic/political groups, in the early 1990s.

\section{Internal Legitimacy}

Many of the post-Soviet states' elites, whether former Communists or the opposition, tried to mobilize people using populist nationalistic and/or ethnic appeals to support their leadership. In addition, the former Communist nomenklatura in the Caucasus states also maintained strong patronage ties with Moscow in order to legitimize external political support and protect themselves against domestic opponents. Another important point was that the nomenklatura of the local Communist Party in the union republics during the Soviet period were ethnically constructed. Thus, the institutional legacy of the Soviet period created a strong incentive to adopt an ethno-national and Moscow-centric political formation in these countries. ${ }^{180}$

\footnotetext{
180 Jack Synder, "Introduction: Reconstructing Politics amidst the Wreckage of Empire" in Post-Soviet Political Order: Conflict and State Building, Barnett R. Rubin and Jack Synder, eds., (London: Routledge, 1998), p. 3.
} 
Moreover, the ruling elites mobilized nationalistic elements when economic crises and political instabilities exposed their vulnerabilities and when challenges from opposing elites and groups emerged. In other words, the ruling elites made use of the politics of clan, region, and religion as symbols to recruit supporters. Under such conditions, ruling elites promoted ethnic nationalism both to strengthen their legitimacy and to denounce the opposition as being divisive. ${ }^{181}$

Yet another underlying feature of the Caucasus states which became apparent due to the influence of the nationalist movements was that informal channels were at the core of their domestic political systems. Leaders of the Caucasus states concentrated their power in order to fully control the state structures and institutions because their authority depended on their control of the governmental mechanism, not popular support and it is difficult to mobilize popular support for their political security when they are experiencing a political crisis and threat. For these reasons, the opposition groups were easily suppressed by the government, and governments, when the leaderships lost control of the state mechanisms, were quickly overthrown by a quick putsch.

Therefore, the weakness of organized political channels exerts contradictory effects on leaders' ability to control their states. As a consequence of the weakness of channels of legality, the leaders can fully control state institutions but the state structure in turn tends to become unstable and crumble easily. Thus, given the absence of effective political constraints on executive power, leaders can dominate the foreign policy process too. In other words, foreign policies are sometimes determined by who is in power and how.

\footnotetext{
${ }^{181}$ Rajan Menon and Hendrik Spruyt, "Possibilities for Conflict and Conflict Resolution in post-Soviet Central Asia," in Post-Soviet Political Order: Conflict and State Building, Barnett R. Rubin and Jack Synder, eds., (London: Routledge, 1998), p. 112.
} 
Because of both the ethnically based and leader-oriented political structure, the Caucasus states had a weak state authority, meaning the absence of government legitimacy and lack of the rule of law in the early 1990s. Instead of judicial rules, order in society was based on force, corruption, and terror. Moreover, a variety of power bases appeared: for example, warlords, paramilitary groups, gangs, extremist movements, ultra nationalists, and clans. These military and political groups fight to control state institutions and benefit from the weakness of the state. Therefore, they can cause a lack of distinction between the private and public realms. For that reason, ruling elites in weak states use the state for their own private purposes; for example, they often sell offices and purchase loyalty through patrimonial offerings. Often, bureaucrats use their positions to enhance their wealth, to provide jobs for their families, clans or tribes, and to make corruption a form of illegal taxation. In order to maintain this arena of privilege, certain clans and tribes in society are favored, while others are excluded from office and resources. ${ }^{182}$ In turn, this creates a setting for protests, rebellions, coups, and secession from the state.

Political power may also be contained by playing the "ethnic card," that is, the creation of ethno-national divisions within society that help maintain loyalty for the ruling elites. The roles of ethno-national or clan/tribal based division stem from favoring certain segments of society and/or excluding certain groups from the state institutions.

In other words, weak states are in effect "kleptocracies" where individuals use the state apparatus to enrich themselves and to create systems of patrimonial rule. In such

\footnotetext{
${ }^{182}$ Robert Legvold, "Outlining the Challenge," in Statehood and Security: Georgia after the Rose Revolution, Bruno Coppieters and Robert Legvold, eds. (Cambridge: The MIT Press, 2005), p. 5. More about clans and clan politics, see Kathleen Collins, Clan Politics and Regime Transition in Central Asia, (Cambridge: Cambridge University Press, 2006) and Edward Schatz, Modern Clan Politics: The Power of Blood in Kazakhstan and Beyond, (Seattle: University of Washington Press, 2005).
} 
cases, public offices become the primary vehicles for family, clan or tribal wealth, and a chain of superior and subordinate bureaucracy serves as the foundation for ruling elites. Under conditions of weak political institutions and insignificant political mobilization, the ruling elites try to stay in power with the help of these traditional methods. This condition sometimes leads to authoritarianism, thereby preventing the overthrow of ruling political elites by other political clans or groups. In conclusion, one can simply say that under such conditions, the state's legitimacy is more easily defended by its foreign policies than domestic ones. At times, domestic issues can divide the nation while foreign issues can play a role in uniting the state.

\section{Coherence of State Institutions}

The Soviet Union was an imperially structured state. The Communist Party was centralized and strictly controlled with multiple significant political and economic channels linking Moscow to the union republics. Moreover, Moscow's political and economic models were duplicated by the all union republics. ${ }^{183}$ In the imperial Soviet state structure, core elites in Moscow led and directed all state agencies, organizations, and institutions, while at the same time, regional or local political elites carried out identical policies in administering their own regions or union republics. The core ruling elites in Moscow made foreign and defense policy, controlled the armed forces and economy, kept law and order, obtained resources, passed legislation, and demarcated

\footnotetext{
${ }^{183}$ Alexander Motyl, Revolutions, Nations, Empires: Conceptual Limits and Theoretical Possibilities, (New York: Columbia University Press, 1999), p. 123. Michael Doyle suggests that "empire... is a relationship, formal or informal, in which one state controls the effective political sovereignty of another political society.” Michael Doyle, Empires (Ithaca: Cornell University Press, 1986), p. 45.
} 
borders. According to Motyl, in turn, regional or local political elites implemented core policies so as to satisfy the core elites and stay in power. ${ }^{184}$

Therefore, both the all Union Communist Party and the union republics were heavily associated with Soviet rule; it was impossible to eliminate the party without, at the same time, bringing down the state. For these reasons, the newly independent states of the Caucasus had the foundations of a state (the government, parliament and judiciary) from the very beginning. In addition, state institutions in the post-Soviet states emerged in an environment of political and economic crisis. Not surprisingly, pressures mounted from both inside and outside of the post-Soviet Caucasus states, as different political groups struggled with the central government for possession of critical resources on their territories.

Furthermore, prior to the collapse of the Soviet Union, independent local decision-making was minimal. Regional and union republics' leaders had little knowledge and experience, not to mention say, in what services were to be provided or how much money would be available for implementing those services. In other words, by the end of the Soviet period, because all decision-making processes disseminated from Moscow, the newly independent states were ill-prepared in carrying out their own governing decisions.

Under similar conditions, following the collapse of the center of the empire, local political elites normally seek to adopt a policy of survival which is challenged by political and ethnic unrest as well as the outcome of political and economic transformation. The most pressing of these challenges is anarchy. As Moscow's control over the armed

${ }^{184}$ Motyl, 1999, p. 120. 
forces, police, and other institutions disappeared, the leaders of post-Soviet Caucasus states most immediate concern was security. Their biggest fear was that rival ethnicbased clans and political groups would engage in violent conflict to overthrow the government and established their own control over the state and its institutions. Therefore, especially in the early 1990s, newly independent post-Soviet political structures were missing elements of law and order in state institutions. In fact, a variety of institutional forms, territorial republics, clans, military units, and factions, served as self-defense groups. Conflicts were less widespread where union republics quickly achieved state control of the security forces to end the security dilemmas of anarchy. This is illustrated in the Baltic states. However, in the Caucasus states (especially in Azerbaijan and Georgia), lack of security, due to the weakness of state structures and institutions, created an opportunity to develop a political system dependent on personal loyalties and kin networks. The weakness of the Caucasus states represents a severe breakdown in the political order of the state due to extended domestic conflicts and the disintegration of public authorities. Moreover, political activities of neighboring countries enhanced unstable political structures and had a destabilizing impact on the state-building process in the region. ${ }^{185}$

\footnotetext{
${ }^{185}$ Weak states typically harbor ethnic, religious, linguistic, or other inter-communal conflicts. In weak states, the ability to provide adequate measures of other political goods is diminished. Weak states are often ruled by despots, elected or not. The weakness of organized ways of political communication has the contradictory effect of making governments both powerful and unstable. Mainly weak states have insecure ruling elites, minimal rule of law, a depressed and broken post-communist economy, authoritarianism, and a hardly noticeable civil society. Alexander J. Motyl, Imperial Ends: Decay, Collapse, and Revival of Empires, (New York: Columbia University Press, 2001), p.107.
} 


\section{Legacy of Past}

Historically, in order to better understand state-building in the Caucasus, one must examine the Tsarist and Soviet legacies. ${ }^{186}$ In certain ways, the Soviet legacy to the Caucasus states was as the Tsarist legacy was to Lenin in 1917. A common characteristic is found in both the arbitrariness and personalization of legitimate authority under the very person of the Tsar, as opposed to its institutionalization under the Duma.

Furthermore, the arbitrary brutality and intolerance of Stalin, coupled with the absence of rule of law under the Communist regime, did not allow the Soviet Union to develop a stable judicial system. As a result, in the post-Soviet Caucasus states, one can clearly see similar approaches, like the arbitrariness that leaders expressed towards their opponents and the general lack of rule of law in the political system. Although there are clauses in their constitutions regarding checks and balances, the role of the judiciary in the state system and the inviolability of democratic procedure, leaders have used their authority to dismiss constitutional laws and governed these countries by fiat.

Both the Tsarist system and Soviet Union exemplified autocratic tendencies towards the Duma and Supreme Soviet, respectively. In the Tsarist regime, the Tsar was the ultimate executor, whereas under the Communist regime, the Party and its leader replaced the central role of the Tsar as the place of ultimate power. The Communist Party executed its own policy agenda via the symbolic approval of the Supreme Soviet. The state held the executive function, in which the Communist Party was the policymaker, in other words, the ultimate authority.

\footnotetext{
${ }^{186}$ Soviet legacy is the deliberation of the Russian history in the last century; that is the continuity of the characteristics of political nature of Russia via transferring those values to the post-Soviet states. See Sergei Medvedev, Rethinking the National Interest: Putin's Turn in Russian Foreign Policy, Marshall Center Paper, August 2004, no. 6.
} 
Currently, the Caucasus states' constitutions grant their presidents an extraordinary amount of authority, similar to the authority once enjoyed by both the Tsar and the Communist Party. Leaders of the Caucasus states, by dismissing the confirmation of Parliament and sometimes constitutions, essentially execute orders at their own will. Thus, the Caucasus political systems inherited the historical legacy of both Tsarist and Soviet authorities.

The judiciary is a key institution in a democracy. The judiciary secures the primacy of the constitutional process and balances as well as controls the extreme moves of the president or whoever has the executive power. In other words, the judiciary upholds the law, thus enabling the democratic process to flow efficiently. Under both the Soviet regime and Tsarist rule, no independent branch of jurisdiction existed. In the Soviet state, the concept of law, rather than of 'rule of law,' was seen as the sum of the measures of the state's imposition of the ideology on a regular basis. The Leninist doctrine denied the principal of judicial review of the Party and state, because as they were already the representatives of the majority class interest and established 'dictatorship of the proletariat', they were a law unto themselves. The Soviet concept of law tended to be an ideological review of the actions of its officials rather than fulfilling legal-jurisdictional functions. For this reason, there is wide consensus that rule of law was absent in the Soviet system in general, as well as in the judiciary in particular.

Moreover, the Caucasus states' brief experience of statehood (1918-1921) had an influence on these states, especially in the early 1990s, as seen in the dominance of a more nationalist discourse among their political elites and the growth of secular nationalist sentiments. Second, the arbitrary imposition of state boundaries in the early 
1920s produced substantial differences between territory and nationalities, and the territorialization of ethnicity. Third, the increased power of the titular nationality created new problems of national minorities. This led to dissatisfaction with borders, and generated ethno-nationalist conflicts while creating the conditions required for intrastate and/or interstate wars, e.g., the role of Karabagh Armenians in conflicts between Azerbaijan and Armenia. Consequently, when an imperial authority collapses, the new state emerging from the imperial political system retains elements of the old regime. ${ }^{187}$

\section{b. Threats}

Chaos in the regional environment poses both external and internal threats to states. External threats can be based on power disparity between neighboring states, geographic proximity of major powers, and hostile goals of neighboring states. Internal threats can be related to historical experience, paramilitary activities of opposition groups, national sentiments of minorities, competition to control natural resources, as well as the need for ruling elites to consolidate their authority.

Russian rule as the central imperial authority had constructed and shaped political structures and borders in the Caucasus for two centuries, except for a short period of time when the Caucasus states had their short-lived independent nation-states following the Bolshevik revolution. With the downfall of this central imperial authority, political structures collapsed and nationalistic political views became dominant in the political arena of the newly independent states. Hostility within and between different ethnic and political communities deteriorated into wars in Abkhazia and South Ossetia in Georgia, and Karabagh in Azerbaijan. Moreover, the Caucasus states experienced a number of coups accompanied by wider internal political conflicts. Thus, most of the conflicts in the

${ }^{187}$ Suny, 1993, p. 99. 
region were based on past grievances and present insecurities of societies, changing ruling elites, and access to resources. ${ }^{188}$

Threats are therefore the result of interactions between external and internal factors; for example, border issues, economic crisis, geopolitical and geoeconomical situations, and the inability of political leadership to provide a basic rule of law. There are some distinctions amongst the threats faced by the Caucasus states. For Georgia and Azerbaijan, the main problems during the early 1990s occurred when dealing with major internal threats. Even though the union republics of the Soviet Union had their bureaucratic structures, the post-Soviet state structures inherited from the Soviet period were too weak to manage ethnic and political divisions such as conflicts amongst clans, nationalities, regions, factions, and paramilitary groups. Therefore, the disintegrating political environments of the former imperial center provided different political and ethnic communities with different opportunities. Moreover, Soviet nationality policies, based on ethno-linguistic territorial divisions, left multiple divisions between the ruling elites and the rest of the population, and between the majorities and the ethno-national minorities.

Furthermore, the sentiments of nationalism among the political elites in the early 1990s allowed for greater concentration divisive nationalistic issues which surfaced in political arena. This had a negative impact on state- and nation-building processes in the Caucasus states. Therefore, the early stages of nation-building and state-building were problematic and often caused states to become more unstable. This was the case in Azerbaijan and Georgia, where the diversity of national and political groups caused many

\footnotetext{
${ }^{188}$ Jonathan Cohen, "Regional Introduction: Struggling to Find Peace," in Searching for Peace in Europe and Eurasia: An Overview of Conflict Prevention and Peacebuilding Activities, Paul Van Tongeren, et a., eds., (Boulder: Lynne Rienner Publisher, 2002), p. 404
} 
significant problems in the state-building process. For instance, both Georgia and Azerbaijan experienced difficulties in controlling illegal paramilitary forces in the early 1990s. ${ }^{189}$ As a result, the mobilization of ethno-nationalism as a political tool in the Caucasus has taken the form of inter-ethnic conflicts. The claims of Armenians in Karabagh in the case of Azerbaijan, and Abkhazians in Abkhazia and Ossetians in South Ossetia in the case of Georgia have focused on the self-determination of their ethnonational groups. The Azerbaijani and Georgian political elites perceived these ethnic minorities' demands as the primary threat to their sovereignty. Consequently, the Caucasus states faced pressing threats to their sovereignty and even survival stemming from their weak legitimacy and historical legacy left by the Soviet Union. For that reason, all of the Caucasus states have attempted to pursue strategies of building up military potential and seeking alliances with major powers to boost their internal and external security. $^{190}$

\section{c. Leadership}

All Caucasus states have presidential systems but their presidential systems differ from the United States presidential system in terms of the capabilities of the president vis-à-vis the parliament. First, in the Caucasus states, though the president is not the executive himself, he is the one who appoints the executive, the prime minister and cabinet members. Second, even though the Parliament has the right to override the president's appointee, this power is irrelevant because the president has the right to

\footnotetext{
${ }^{189}$ Cohen, 2002, p. 405.

190 Jonathan Aves, "National Security and Military Issues in the Caucasus: The Causes of Georgia, Azerbaijan, and Armenia," in State Building and Military Power in Russia and the New States of Eurasia, ed. By Bruce Parrott (Armonk; M.E. Sharpe, 1995), p. 211.
} 
dissolve the parliament. In other words, a rational parliament would not override the president's appointee because, most likely, it would mean their dissolution as well. Just as the Tsar claimed to be the personification of his subjects, and the Communist Party claimed to be the representative of the interest of the people, the presidents in the Caucasus states follow the same rhetoric and course of action. Parliaments remain mostly obsolete due to the balance of power being mostly placed under the president. Thus the presidency in the Caucasus states in effect represents the whole of the nation. In essence, both the Tsarist and Soviet legacies prevented the Caucasus states from developing a checks and balances system.

In addition, in the Caucasus states, because of the weaknesses of state institutions and ineffective administrative structures, the presidents have flexibility and a substantial margin of maneuver in implementing their foreign policy objectives. ${ }^{191}$ Therefore, different personal interests of leaders tend to respond differently to similar conflicts. For instance, self-oriented leaders, on the one hand, seek to respond to domestic threats in the course of power accumulation and balancing, such as Aliyev's policies in the early 1990s. Nationalist-oriented leaders, on the other hand, may construct an isolationist policy, which allows them to isolate their countries from external intervention to their domestic problem, such as in Georgia under the leadership of Zviad Gamsakhurdia.

Moreover, the early leaders of the Caucasus states were keen anti-imperialists and nationalists. Levon Ter Petrossian in Armenia, Ebulfaz Elchibey in Azerbaijan, and Zviad Gamsakhurdia in Georgia were all leaders of dissident movements during the Soviet time and effectively became leading figures of nationalists movements of their respective

${ }^{191}$ Aves, 1995, p. 211. 
countries in late 1980s. ${ }^{192}$ All three leaders faced political and economic insecurity. In the meantime, the nationalist leaders of Azerbaijan and Georgia perceived the elimination of external threats as a precondition for establishing internal control and legitimacy. As the state-building process advanced and internal political stability increased in the late 1990s, the leaders of the Caucasus states obtained greater autonomy from internal restraints to concentrate on foreign policy issues.

The nationalist leaders of the Caucasus states also developed their policies based on anti-imperialism in order to oppose internal political groups and elites who received political support from the former imperial center. Therefore, nationalist leaders emphasized the rejection of the previous imperial order, even if the ex-imperial power was no longer a real threat, and assumed the former imperial central as potential threat because they considered it to be a useful tool for maintaining unity and power in the country. This was one of the main reasons why opposition to Russia's role in the region and rising nationalism had grown more intense in the early 1990s. Nationalist policies brought more attention to the differences between "us" and "them", thus, defining political and economic power in certain areas that supported members of certain ethnic and political groups, such as under Gamsakhurdia's tenure in Georgia. As it turned out, the greater the degree of ethnic diversity within a state is, the greater the danger that ethnic nationalism would create instability and conflict in the state. ${ }^{193}$

In summary, politics in the Caucasus maintains the characteristics of the Tsarist Russian and Soviet political orientations toward authoritarianism, and this tendency, even in the form of democratically elected presidents seen as essentially 'good tsars', has

\footnotetext{
${ }^{192}$ Suny, 1993, p. 131.

${ }^{193}$ Rajan Menon and Hendrik Spruyt, 1998, p. 112.
} 
continued to dominate and shape post-Soviet state-building processes and state institutions in the Caucasus.

\section{d. External Influence}

External power commitments refer to a major power supporting and providing a weak state with military, economic, and/or political assistance. The commitment does not necessarily mean an alliance is formed with a weak state. Primarily, the relationship formed with the weak state offers assistance so the weak state deals with internal and external political and economic difficulties and threats. Major powers are capable of playing a strong role in supporting weak states by distributing aid, serving as role models, granting certain guarantees, and integrating states into the international and regional system.

The Caucasus states' experienced serious difficulties in establishing political and economic security for their states and citizens. As a result, they searched for alliances amongst the global and/or regional major powers, such as the United States, Russia, Turkey, the European Union and Iran. Historically, the power and influence of the Russian and British empires, Turkey, Iran, and the United States has ebbed and flowed across the region. For example, Russia, as both the ex-imperial center and dominant regional power, has the capacity to manipulate links to domestic elites of the Caucasus states to project Russian interests in the region. Such activities may raise other major powers' interests thus prompting a response that may escalate competition among major powers. The response of the other powers to the Russian dominance in the region changed from weak to strong from the first half of 1990s to the second half of 1990s. 


\section{Russian Interests and Involvement}

The disintegration of the Soviet Union left Russia to look for a new perspective for its security policy. In many questions, such as whether or not Russia's status as a superpower remains intact, Russia's global influence decreased significantly in the 1990s; however, it remains very influential around its borders. Russia's policies towards the former union republics of the Soviet Union, referred to as the "Near Abroad", have caused concern for some of its neighboring countries as well as western major powers, due to the nature and direction of Russian foreign policy. ${ }^{194}$

In the early 1990s, Russia’s foreign policy was pro-Western in orientation; however, Russia shifted its approach to a more assertive stance due to reconsiderations of Russian increased geopolitical and geo-economical interests and involvement in the Caucasus region. An underlying shift amongst Russia's political elites was driven by the hardships of reform in Russian politics and economy and the manifest implausibility of Russia's integration into Western security institutions. This produced a revival of Russian nationalism and mistrust of the West. This development towards a stronger and more nationalist foreign policy was both reflected in, and influenced by, the pro-imperialist Communist Party and nationalist parties, like Zhirinovsky’s Liberal Democrat Party and deputies in the Duma. Therefore, during the 1990s the rise of Russian nationalism became associated with increased tensions with the United States over such issues as the

\footnotetext{
${ }^{194}$ John W. R. Lepingwell, "The Russian Military and Security in the 'Near Abroad', Survival, Autumn 1994, vol. 36, no. 3, pp. 70-92, p. 70 and Elizabeth Fuller, "Russia's Diplomatic Offensive in the Caucasus," RFE/RL Research Report, 1 October 1993, vol. 2, no. 39, p. 30. See also, Mark Smith, Pax Russica:Russia's Monroe Doctrine, (London: Royal United Services Institute for Defence Studies, 1993), and Mark Almond, Russia's Outer Rim: Integration or Disintegration?, (London: Institute for European Defence and Strategic Studies, 1995).
} 
expansion of NATO, the Russian-Iranian nuclear reactor deal, and Russian military actions in Chechnya. ${ }^{195}$

Russia's first concepts of foreign policy and military doctrine, two key issues that guided its more aggressive foreign policy, were approved in 1993. According to these two documents, Russia saw itself as the natural hegemon in the former Soviet lands. The Russian government also considered that the United Nations should recognize Russia as only country to have peacekeeping forces for the regional conflicts in the Caucasus and Central Asia. ${ }^{196}$

Russian foreign policy substantially shifted towards the Caucasus as conditions worsened in Chechnya in 1993. Although Russia's 1993 military doctrine does not specifically identify new 'threat axes,' its references to regional conflicts correspond to many official statements of Russian politicians and military officials asserting the importance of maintaining a defensive zone around the Caucasus. For instance, the Russian Defense Minister, Pavel Grachev, claimed in 1993 that "instability in the Caucasus and neighboring regions and the growth of separatism and extremism necessitates a significant Russian military presence in the North Caucasus region in order to prevent and deter potential conflicts and insure against the destabilization of the situation on the European conflict as a whole."197

\footnotetext{
195 Almond, 1995, pp. 8-10.

${ }^{196}$ Margot Light, "Foreign Policy Thinking," in Internal Factors in Russian Foreign Policy, Neil Malcolm, et al., eds., (Oxford: Oxford University Press, 1996), pp. 62-63.

${ }^{197}$ John W. R. Lepingwell, “Restructuring the Russian Military,”RFE/RL Research Report, vol. 2, no. 55, 18 June 1993, p. 18; and Leon Aron, "The Emergence Priorities of Russian Foreign Policy," in The Emergence of Russian Foreign Policy, Leon Aron and Kenneth M. Jensen, eds., (Washington, D.C.: United States Institute of Peace Press, 1994), p. 28.
} 
Moreover, the Caucasus is also important to Russia's long-term political and economic interests. Even Russia's economic ties with the Caucasus states had weakened considerably and trade had severely diminished due to blocked railways and roadways in both Abkhazia and Chechnya in the early of 1990s. Russia hoped oil from the Caspian Sea would pass through its own pipeline and terminal system so that Russia could monopolize local pipeline systems and control the energy resources of the region. As the Caspian Sea is landlocked, the shortest route to the world's major seaways is by tanker to the Mediterranean via the Black Sea. On the Black Sea, Novorossiisk and Tuapse (Russian ports), and Batumi and Poti (Georgian ports) are the main terminals for the oil pipelines. In March 1995, following a security agreement between Georgia and Russia, Russia had gained significant control of all these Georgian ports either directly or indirectly. ${ }^{198}$

Russia's strong position in the region, combined with political and economic pressure on Azerbaijan and Georgia, was used strategically to remind the Caucasus states and the other major powers of Russia's dominance in the region. In Azerbaijan, the Russian Defense Ministry supported Suret Huseyinov's coup to oust Elchibey two weeks before Elchibey was due to fly to London to sign a contract with the international oil consortium for the exploitation of the Caspian oilfields. In addition, Russia's interference has kept Armenia and Azerbaijan in disagreement while placing Russia in the intermediary position for bringing about a ceasefire to the Karabagh conflict. ${ }^{199}$

\footnotetext{
198 Jennifer DeLay, “The Caspian Oil Pipeline Tangle: A Steel Web of Confusion,” in Oil and Geopolitics in the Caspian Sea Region, Michael P. Croissant and Bulent Aras, eds., (Westport: Praeger, 1999), pp. 4950 .

199 Sabit Bagirov, “Azerbaijan's Strategic Choice in the Caspian Region," in The Security of the Caspian

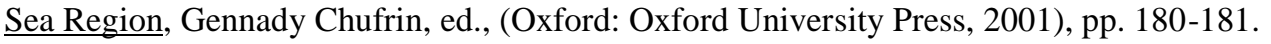


However, Russia's role in the region has been somewhat limited due to the expansion of NATO and emergence of GUAM (Georgia, Ukraine, Azerbaijan and Moldova) as opposed to the Commonwealth of Independent States (CIS)'s security framework. ${ }^{200}$ In New York in September 1993, in his address to the UN General Assembly, the Russian foreign minister Andrei Kozyrev proposed that Russia be granted a special peacekeeping role in the areas of the former USSR, and he suggested that the UN finance Russia's role as a regional peacekeeper. ${ }^{201}$ Kozyrev's proposal was rejected; the strongest of negative sentiments against the proposal came from the Baltic states, Ukraine, and Turkey.

Moreover, the Russian Defense Minister, Pavel Grachev, had visited the Caucasus three times in 1994. The issues that Grachev discussed with his counterparts of the Caucasus states during the trip were Russia's military presence in the region, the settlement of conflicts in the Caucasus, and Russia's military cooperation with the Caucasus states. ${ }^{202}$

Russia favored the CIS as a channel for security cooperation in the post-Soviet states. At the May 1992 Tashkent meeting of the CIS, Russia asked the former Soviet republics to form a CIS collective security alliance. In the Caucasus, only Armenia joined the alliance. Armenia needs Russian support for its drive to unite with Azerbaijan's Karabagh region and wanted Russian protection against the Turkish influence in the

\footnotetext{
${ }^{200}$ Elkhan Nuriyev, The Post-Soviet Caucasus within New Geopolitical Framework: Towards Conflicts or Peace?, (Bonn: Arbeitsstelle Friedenforschung Bonn (AFB)-Texte Series, 2000), no. 3, p. 9.

${ }^{201}$ Ted Hopf, "Identity, Legitimacy, and the Use of Military Force: Russia’s Great Power Identities and Military Intervention in Abkhazia," Review of International Studies, 2005, no. 31, p. 237.

${ }^{202}$ Ilya Bulavinov, "Result of Pavel Grachev's Visit to the Transcaucasus: Minister at the 'Point of Return'; A Tour of Stalin Sites" Kommersant-Daily, 1995, March 25, p. 4 in The Current Digest of the Soviet Press, Editors' Note, 1995, vol. XLVII, no. 12, p. 22.
} 
Caucasus. Azerbaijan refused to join the alliance because the Elchibey government believed Russia was provoking and supporting the Armenian forces against Azerbaijani forces in Karabagh. Azerbaijan also wanted to expand its relations with Turkey and the West. The Georgian government also rejected the CIS alliance because it perceived Russia as being sympathetic to and supportive of the Abkhazian separatists and unfriendly to Georgia's drive for national independence. ${ }^{203}$ However, after the leaderships changed in Azerbaijan and Georgia, both states agreed to join the Collective Security Treaty and signed the agreement on collective security, the agreement for the joint defense of CIS borders and the creation of a common air defense system. Thus, Russia secured its role as the principal external player in the Caucasus.

On February 28, 1993, Yeltsin addressed the Russian government on the subject of peacekeeping in the former Soviet Union. He declared, "Russia continues to have a vital interest in the end of all armed conflicts on the territory of the USSR." Furthermore, he claimed, "the international community is increasingly coming to realize our country's special responsibility in this difficult matter. I believe the time has come for authoritative international organizations, including the United Nations, to grant Russia special powers as guarantor of peace and stability in this region." ${ }^{204}$ In the fall of 1993, the Russian government placed Russian peacekeeping forces throughout the Caucasus in order to

\footnotetext{
${ }^{203}$ Robert V. Barylski, "Russia, the West, and the Caspian Energy Hub,” Middle East Journal, Spring 1995, vol. 49, no. 2, p. 220.

${ }^{204}$ Susan L. Clark, "Russia in Peacekeeping Role," in The Emergence of Russian Foreign Policy, Leon Aron and Kenneth M. Jensen, eds., (Washington, D.C.: United States Institute of Peace Press, 1994), p. 120.
} 
preserve Russia's interests in the region. By November 1994, Russia had managed to secure border patrol arrangements with the Armenian and Georgian governments. ${ }^{205}$

Furthermore, in Karabagh Russian troops monitor a ceasefire agreement the Russian diplomats negotiated together with the OSCE-organized 'Minsk group' as mediators and one of co-chairs. The Abkhazian conflict that Russian used to pressure Georgia into joining the CIS is monitored by Russian peacekeepers and international observers under the auspices of a United Nations mission. The South Ossetian conflict is also monitored by Russian peacekeepers under the auspices of the OSCE. ${ }^{206}$ Although Russia had played a key role in negotiating a ceasefire in both Abkhazia and Karabagh, its capacity to influence events in the Caucasus was in decline due to increased notions of sovereignty among ruling elites of the Caucasus states and western major powers' involvement to the region. The Caucasus states were also becoming more integrated into the complex web of bilateral and multilateral international and regional systems. These transitions coincided with the two Chechen wars in the 1990s, both of which weakened Russia's financial and political assets and created tensions between Russia with Azerbaijan and Georgia. As a result, Russia's image throughout the region grew ever more complicated; for example, Azerbaijani and Georgian leaderships remained skeptical and untrusting, whereas the Armenian leadership still welcomed Russian support.

In sum, the Russian roles in the ethnic conflicts and military-bases issue are a good assessment of the Russian influence and strategic significance in the region. Armenia views Russia as a crucial ally for its own national security; however, both

\footnotetext{
${ }^{205}$ Roy Allison, "Military Factors in Foreign Policy," in Internal Factors in Russian Foreign Policy, Neil Malcolm, et al., eds. (Oxford: Oxford University Press, 1996), p. 274.

${ }^{206}$ Barnett R. Rubin, "Conclusion: Managing Normal Instability," in Post-Soviet Political Order: Conflict and State Building, Barnett R. Rubin and Jack Synder, eds. (London: Routledge, 1998), p. 169.
} 
Azerbaijan and Georgia are suspicious of Russia's true intentions in the region and perceive Russian role as more of a threat. Furthermore, Armenia allowed Russian military bases on its soil as part of its national security plan, while Georgia strongly opposed continued Russia basing rights, and Azerbaijan rejected Russian demands to have military bases in Azerbaijan. ${ }^{207}$

\section{American Interests and Involvement}

In the early 1990s, America's priority was to re-establish a constructive foreign policy with Russia. For the most part, both the Bush and Clinton administrations ignored the Caucasus states. The United States had adopted a very cautious approach to the region due to the priority of integrating Russia into the international system in the early 1990s. Before 1994, the U.S. policies in the Caucasus sought to cooperate with Russia by improving the political stability of Russia through state and institution building and encouraging economic reforms. However, these political and economic reforms were limited and did open a way for the pro-imperialist political groups to dominate Russian politics. ${ }^{208}$ Russia pursued more aggressive policies towards to the Caucasus states after the initial shock of the collapse of the Soviet Union.

Nevertheless, during the second half of the 1990s, the United States' foreign policy shifted, becoming more focused on the Caspian region. Energy interests, in particular oil, became a vital issue after the signing of the "Contract of the Century"

\footnotetext{
${ }^{207}$ While allowing Russia to continue using the Gabala Radar Station, Azerbaijan ignored pressure from the Russian government a long-time and delayed to implement the agreement on a long-term lease of the radar station. See, Pavel Baev, Russia Refocuses its Policies in the Southern Caucasus, Harvard University, Caspian Studies Program, Working Paper Series, July 2001, no. 1, p. 15. Additionally, Sinan Ogan, "Gabala Radar Station: Somebody is Watching Us," Turkish Daily News, 13 March 2002.

${ }^{208}$ Paul A. Goble, "Ten Issues in Search of a Policy: America's Failed Approach to the Post-Soviet States," Current History, October 1993, vol. 92, no. 576, pp. 305-306.
} 
between major oil corporations (including four American companies) and the Azerbaijani government in September 1994. The United States' foreign policies carried out in the region were visualized with pipeline politics in mind. However, many sensitive political themes have since arisen, such as balancing relations with Russia, the influence of the oil lobby, and the Armenian Diaspora, as well as uneasy relations with Iran, all of which have created limitations on U.S. influence in the region.

Therefore, feeling pressure from oil giants Amoco, Mobil, Exxon, and Chevron, the Clinton Administration adjusted its pro-Russian policy and began to back the Caucasus states. In doing so, Washington's actions appeared to weaken Russia's influence in the region. ${ }^{209}$ Furthermore, the United States' policies directed against Iran forced western oil corporations and the Azerbaijani consortium to cancel a 5\% share it had given to the Iranian oil company. By ruling out a pipeline route that would have passed through Iran, the United States pushed the one regional power, Iran, closer to the Russia. ${ }^{210}$ Thus, access to Caspian oil became a major American interest and the United States' policies in the region began to shift from that of passive observer to active player. For instance, the United States President's Special Advisor on the CIS, Richard Morningstar, reported to Congress that establishing this network of pipelines is a central objective of the American policy in the region. According to Morningstar, the United States has five strategic objectives in the Caspian region: strengthening the independence of the new Caucasus states, mitigating regional conflicts by building economic linkages among the new states of the region, enhancing commercial opportunities for United

\footnotetext{
${ }^{209}$ Andrei Tsygankov, Pathways After Empire: National Identity and Foreign Economic Policy in the PostSoviet World (Lanham: Rowman \& Littlefield Publishers, Inc, 2001), p. 119.

${ }^{210}$ Peter Galuszka and John Rosant, Business Week, 17 July 1995, p. 52.
} 
States and Western companies, bolstering the energy security of the United States and United States allies, and the energy independence of the Caspian region by ensuring the free flow of oil and gas to the world market place. ${ }^{211}$

In conclusion, the regional system which has formed around the Caspian region is in response to the decline of Russia's political influence, an increased sense of nationalism, and the arrival of major Western energy corporations. The Caspian region contains major oil and gas deposits that have attracted multi-billion dollar investments by Western companies. Since multinational oil companies, the United States, and other Western powers have entered the Caspian political circle, they have developed real interests in the region. $^{212}$

\section{Turkish Interests and Involvement}

In the second half of the $19^{\text {th }}$ century, hundreds of thousands of Muslim Circassians, Abkhazians, Dagistanis, Georgians, Azerbaijanis, Chechens, and Lezghians fled from Russia's invasion of the Caucasus, seeking refuge in the Ottoman Empire. Eventually, large numbers of different ethnic groups from the Caucasus were settled in various regions of the Ottoman Empire, especially today's Turkey. These Caucasus diasporas have not forgotten their ancestral lands and created public pressure on the Turkish government. Therefore, the Turkish government has been forced to balance these Diasporas' desires and demands with Turkey's relations with neighboring states, including Russia and the Caucasus states. ${ }^{213}$

\footnotetext{
${ }^{211}$ Richard Morningstar, “U.S. Energy Policy Toward the Caspian Basin,” CERA Conferences, Washington, D. C., 7 December 1998, www.mtholyoke.edu/acad/intrel/morning.htm 
In the early 1990s, Turkey changed its methods and approach to developing foreign relations with the Caucasus states. ${ }^{214}$ Turkish President Turgut Ozal's plans for becoming a major player in energy affairs were linked to vital strategic and economic objectives of influence and resistance to Russia throughout the Caucasus. Therefore, the importance of establishing good relations with the Caucasian states grew increasingly from both a political and an economic viewpoint. Turkey had gradually discarded its passive neutrality, a stance that dominated its foreign policy throughout the late $20^{\text {th }}$ century, and emerged as a regional power. This crucial change in Turkey's foreign policy effectively began when Azerbaijan's deputy foreign ministry Azimov noted, "there has been unofficial talk of a military alliances with Turkey" and even "talk of extending the NATO umbrella via Turkey to include Azerbaijan. Turkey has built a rail and road link to Nakhichevan."215 Nevertheless, Russian's constant attempts to dominate the region have limited Turkey's ability to carry out its major objectives in the Caucasus.

Historically, Turkey's interests in the Caucasus have always concerned Russia. For example, Turkish support for Azerbaijan has posed a particular threat to Armenia, where attempts at normalization have been hampered, not only by the Karabagh conflict, but also due to the differing views on the alleged Armenian 'genocide' of 1915. In the 1990s, the interests of Western multinational oil corporations in Azerbaijani oil fields had sparked the opportunities of transporting Azerbaijani oil via Turkey to a Mediterranean port; therefore, the construction of the pipeline through Turkey became one of the most

\footnotetext{
${ }^{214}$ Philip Robins, "Between Sentiment and Self-Interest: Turkey’s Policy toward Azerbaijan and the Central Asian States," Middle East Journal, Autumn 1993, vol. 47, no. 4, p. 610.

${ }^{215}$ Interview with the Deputy Foreign Minister of Azerbaijan, Azad Azimov, 07 January 2006.
} 
debated issues among the Caucasus states and major powers in the second half of the 1990s.

In conclusion, Turkey's role as a regional power curtailed Russia's efforts to dominate the area, thus increasing Turkey's status as one of the major regional powers. In the 1990s, Ankara perceived Russia's Caucasus policies as a threat to Turkey's interests in the region. ${ }^{216}$ Over the last decade and half, the importance of Turkey's role and identity in the international community, one of the most active major powers and a partner of western states, especially the United States, has increased significantly in the region. American and Turkish interests coincide with each other. Turkey continues to place its relations with Europe and the United States at the top of its list of foreign policy priorities. Turkey thus extended its political and economic influence in the Caucasus and Central Asia as a supplemental way of extending its role in international and regional politics. However, Turkey still remains cautious about the role of Russia in the region.

\section{Iranian Interests and Involvement}

Unlike Turkey, which borders all three Caucasus republics, Iran shares a border with Azerbaijan and Armenia. After the Soviet Union disappeared, Iran and Russia have developed close relations and a common stance on Caucasus regional security issues. The political and economic relationship between Russia and Iran improved tremendously in the 1990s. Moreover, the Russian and Iranian approaches to most of the Caucasus problems, including the Karabagh conflict, are similar. Iran has played a mediator role between Armenia and Azerbaijan in the Karabagh conflict and in some respects is sympathetic to Armenia. Iran also sought to counterbalance Turkey's influence in

\footnotetext{
${ }^{216}$ Stephen Blank, "Energy and Security in Transcaucasia," Problems of Post-Communism, July/August 1995, no. 16-17, p. 610.
} 
Azerbaijan, in part to prevent the United States from entering the region. Therefore, during the 1990s Iranian policy progressed towards a more realistic understanding with Russia. Thus, Iran has a broader strategic interest in establishing good relations with Russia; given the pressures to which it is subjected to by the West, and specifically the United States, Russia offers Iran options in trade, the selling of weapons, and in the development of nuclear energy. ${ }^{217}$

Azerbaijan is very important to Iran, but Iran fears the rise of Azerbaijani nationalist movements by the Azerbaijani Diaspora living in Iran. Iran's relations with Armenia, which are closer than they are with Azerbaijan, reveal that interpretations of religious affiliations and ethnic kinships may not always disguise geopolitical interest or legacies of the past in this region. In Azerbaijan, there is a perception of Iran as being a historical overlord, while the issue of a considerable Azerbaijani population in northern Iran or southern Azerbaijan in Iran, which encouraged Azerbaijani nationalists to call for a reunification of Azerbaijan in the early 1990s, tempers Iranian foreign policy in the Caucasus. Iran has provided an important economic channel for Armenia and has used this relationship to advance common interests with Russia. $^{218}$

\section{e. Conclusion}

Based on all notions of state strength (relational, structural and domestic strength or internal and external strength) Azerbaijan and Georgia had problems. Their relational strength did not exist. Their structural strength was weak. Thus, during the first half of

\footnotetext{
${ }^{217}$ Fred Halliday, “The Empires Strike Back? Russia, Iran and the New Republics,” World Today, November 1995, pp. 221-222.

${ }^{218}$ Geoffrey Kemp, “U.S.-Iranian Relations: Competition or Cooperation in the Caspian Sea Basin,” in Energy and Conflict in Central Asia and the Caucasus, Robert Ebel and Rajan Menon, eds., (Lanham: Rowman \& Littlefiled Publishers, Inc., 2000), pp. 150-151.
} 
the 1990s, Azerbaijan and Georgia had neither internal nor external strength in adequate measure.

There were struggles among Azerbaijani and Georgian political elites to control state institutions. This competition became violent and created disorder. Moreover, both Azerbaijani and Georgian leaders who replaced the first presidents of these countries had legitimacy problems. Therefore, political disorder and instability, fighting among political elites and problems of legitimacy weakened these countries' strength.

The weakness of these states was not only the result of these factors but also of ethno-national division within these states. For example, Azerbaijan and Georgia had ethno-national problems within their territories. These conflicts, combined with other political and economical transitional problems weakened Azerbaijan and Georgia more than Armenia.

In the case of Armenia, this state had considerable internal strength: a relatively stable government, strong public support for the government, and well-established state institutions and political mechanisms. In other words, Armenia had established a viable internal order and domestic strength in the early 1990s, when Azerbaijan and Georgia had to deal with domestic disorders, coups, and assassination attempts. However, all the Caucasus states were lacking of external strength sufficient to respond to other states' or actors' actions.

In the Caucasus states, the top leaders always had the last word and controlled the central state mechanism; for these reasons they did not have any real obstacle to implement their policies. During the 1990s, the only way the Caucasus leaders lost their power was through coups d'etat. Therefore, for the leaders, coup attempts became the 
real threats. One reason was the lack of organized channels for opposition to voice their concerns and interests. Clan-based political structures all reflected lack of confidence the state institutions. As a result, the leaders used their administrative authority to stay in power. These conditions allowed leaders to define and articulate the foreign policies of their own countries.

Because of the weakness of state institutions and lack of legacy of statehood, conflicts both between ethnic groups and between political elites turned into the main threat to political leaderships in the Caucasus. Therefore, the Caucasus states were sensitive and vulnerable to internal external threats. These internal threats in these countries not only threatened the leaderships of these countries but also shaped the foreign policy orientation of these countries. So these countries sought external assistance to deal with internal challenges. This is especially true for Azerbaijan and Georgia.

Therefore, these states were also vulnerable to external threats. However, they could not deal with any external threat through their own capabilities. They needed to have alliances with powerful states to deter potential external threats. When a major power, such as the United States, shifted its foreign policy related to the region, the shift caused certain changes, such as structural and functional changes to the region's features. For example, the Caucasus states had an alternative major power, the United States, in the region to balance Russia so Russian influence on the Caucasus states' domestic politics and foreign policy decreased during the second half of the 1990s. 


\section{Armenia}

\section{a. Strength of State}

In the late 1980s, with Gorbachev's reform attempts, the political climate began to change not only in Moscow but also in the Armenian SSR. A powerful mass nationalist movement quickly spread among Armenians in Armenia and Karabagh for unification on irredentist grounds. The opposition to the Armenian Communist nomenklatura came together under the "Committee of Armenia for the Karabagh Movement" during the same time period. ${ }^{219}$ Most of the members of the Committee consisted of the Armenian intelligentsia. The Communist elite had no influence in its formation and initial activities. The Karabagh Committee had, however, a more diversified agenda than unifying Karabagh and Armenia. ${ }^{220}$ Thus, mass movements and the gathering of people around this shared goal characterized the Armenian political atmosphere between the periods of 1988 to 1990. Furthermore, these political developments in Armenia navigated the transformation of the Karabagh Committee from being a mass nationalist movement to being a party of government, the Armenian Pan-National Movement (APNM).

Despite the arrest of the Karabagh Committee members in 1988, later a kind of agreement between the Communist nomeklatura and nationalist Karabagh Committee members, the leading figures in the Committee were invited to participate in sessions of the union republic's Supreme Soviet. Moreover, after the APNM's victory in the June 1990 elections to the Supreme Soviet in Armenia, APNM formed the country's

\footnotetext{
${ }^{219}$ Suny, 1993, p. 134.

${ }^{220}$ One of the leading members of the Karabagh Committee recalled that the question of Karabagh's unification was "a pretext for expressing the discontent which has been accumulating over decades in the face of social justice, corrupt leaders, the degradation of the environment and the decline of cultural and moral values." In Claude Mouradian, "The Mountainous Karabagh Question: An Interethnic Conflict or Decolonization Crisis?” Armenian Review, Winter 1991, vol. 32, no. 1, p. 22.
} 
government in Armenia, in the process distributing some ministerial positions to representatives of the old Communist elites. Therefore, Armenian politics in the early stage tended to look for a consensus on goals and the means to achieve them. Thus, the domestic political arena was stable and the same political party, the APNM, and the same leader, Ter Petrossian, were continuously in power from 1990 to 1998. This consolidation of power by the leading political force was greatly affected by a number of factors, such as military successes in Karabagh, as well as by the ethnic homogeneity of the population, and the relative unimportance of regional, clan and other sub-ethnic groups. Moreover, the relatively smooth transition was facilitated by the opposition leadership by making informal and formal pacts with the Soviet era ruling elites, the early subordination of paramilitary groups to central political control, and the creation of a powerful state apparatus, all of which affected positively Armenia's early transition period and helped the country to establish strong state institutions. ${ }^{221}$

Furthermore, because of no real minority problem and strong national identity, nation-building and comparatively state-building processes were much easier and smoother than in other Caucasus states. In addition, there is an estimated Armenian Diaspora outside Armenia of more than 1.4 million (with at least 450, 000 in the United States) who are strong and politically active. With an independent Armenia, Diaspora Armenians have materially and morally invested heavily in Armenia and represented Armenian interests in their community and their countries. In addition to that, some prominent Armenian émigrés have worked for the Armenian government; for example, Raffi Hovanassian, citizen of the United States, who worked as a foreign minister.

${ }^{221}$ Gerard J. Libaridian, Modern Armenia: People, Nation, State, (New Brunswick: Transaction Publishers, 2004), pp. 233-234. 
Successful lobbying efforts in the United States Congress have even made Armenia the second-largest per-capita receiver of United States foreign aid, behind Israel, with $\$ 126$ million in $1995 .^{222}$

The Karabagh issue unified all Armenian political groups and elites. Massive demonstrations began to spread from Karabagh and then Yerevan in the late 1980s. Therefore, the Karabagh issue was the dominant factor determining the behavior of all political groups and activities in Armenia, from dissidents and opposition elites to the ruling communist elites. Moreover, the Armenian movements for Karabagh were the engines for public demonstrations for an attack on Soviet institutions. ${ }^{223}$ The need to unify and protect Armenian interests was the driving force that influenced different political groups within Armenia to drop their differences and cooperate in favor of common causes and in opposition to common enemies. Thus, Armenian nationalism and the Karabagh issue promoted Armenian political development because it pushed other issues off the political agenda and strengthened the power of the presidency at the expense of the parliament and political parties.

\section{Coherence of State Institutions}

Two principal parties dominated the Armenian political scene in the early 1990s. They were the Armenian Pan-National Movement (APNM) and the Armenian Revolutionary Federation (the ARF-Dashnak). The APNM, created in 1989, emerged as the dominant political group in the national political arena. When the transfer of power from the communists to the nationalists occurred, the APNM enjoyed huge domestic

\footnotetext{
${ }^{222}$ Betty Blair, "Diplomatic Interview: American Embassy, Richard Kauzlerich,” Azerbaijan International, Autumn 1995, vol. 3, no. 4, pp. 48-49.

${ }^{223}$ Libaridian, 2004, p. 231.
} 
support in the early 1990s. Levon Ter-Petrossian was elected in October 1991 as the first president of Armenia following the declaration of independence. APNM played a crucial role in the transition from a Soviet republic to independent country, maintenance of stable government, and the integration of paramilitaries into an organized armed force. In addition, the APNM leadership, under Ter-Petrossian, took a very pragmatic approach to both domestic and foreign policy issues. Ter-Petrossian, who favored disregarding the past and establishing good relations with Turkey, seemed to be inclined toward a peaceful settlement and thus compromised on the Karabagh issue to end conflict with Azerbaijan. On the other hand, the main opposition party, Dashnak, whose foundation goes back to the $19^{\text {th }}$ century and which has extremely nationalistic-irredentist over tones, favored the establishment of Greater Armenia and revenge against Turkey. ${ }^{224}$ However, Dashnak seems to have had much less support in Armenia than among the Armenian Diaspora in the U.S. which was behind the murderous campaign against Turkish diplomats during the 1970s and 1980s. ${ }^{225}$ The outlawing of this party from political activities in Armenia in 1994 by the Ter-Petrossian government was viewed as a favorable sign by the Turkish government. $^{226}$

Therefore, the APNM faced challenges to its position both from the old Communist nomenklatura and from opposition political movements, principally the ultra-

\footnotetext{
${ }^{224}$ Razmik Panossian, "Post-Soviet Armenia: Nationalism \& Its (Dis)contents," in Making and Protecting the Nation in Postcolonial \& Postcommunist States, Lowell W. Barrington, ed., (Ann Arbor: The University of Michigan Press, 2006), pp. 227-228.

${ }^{225}$ Mim Kemal Oke, The Armenian Question 1914-1923, (Oxford: K. Rustem \& Brother, 1988), p. 269 and Razmik Panossian, The Armenians: From Kings and Priests to Merchants and Commissars, (New York: Columbia University Press, 2006), pp. 310-311. See also, Francis Hyland, Armenian Terrorism: The Past, the Present, the Prospects, (Boulder: Westview, 1991) and Michael M. Gunter, Pursuing the Just Cause of Their People: A Study of Contemporary Armenian Terrorism, (Westport: Greenwood Press, Inc., 1986).

${ }^{226}$ Libaridian, 2004, p. 238.
} 
nationalist Dashnak, which was critical of the APNM's political and economic policies. APNM's success owes to its heterogeneous social roots and the triumph of the Karabagh conflict. The movement embraced both unofficial mainstream nationalist activists and representatives of the Soviet elite, particularly from the intelligentsia and the Komsomol. Moreover, the Armenian Communist Party did not have in its ranks a figure of Shevardnadze's or Aliyev's stature. The APNM was also relatively competent in the way it successfully influenced the ruling elite through its program of economic reform. ${ }^{227}$ Thus, the main reason for the Ter-Petrossian government's ability to resist a strong nationalist movement like the Dashnak was clearly the success Armenia enjoyed in the Karabagh war. The victory in Karabagh provided popular legitimacy for the Armenian government.

Furthermore, the Ter-Petrossian government was supported by different paramilitary and political groups, which included large groups such as the Armenian National Army (ANA), which had substantial support in Yerevan. Ter-Petrossian was able to secure support from the ANA and large numbers of ANA members were integrated into the official security structures of the government. ${ }^{228}$ Therefore, in general, there were no significant militia forces struggling to seize power within Armenia. This may be due to the fact that the fight for Karabagh took place beyond Armenia's borders and most of paramilitary groups were part of Armenian fighting forces in Karabagh. While Armenian governments in Armenia have been involved in the Karabagh conflict, they have always denied any direct military contribution but all evidence indicates

\footnotetext{
${ }^{227}$ Aves, 1995, p. 222.

${ }^{228}$ Joseph R. Masih and Robert O. Krikorian, Armenia: At the Crossroads, (Amsterdam: Harwood Academic Publishers, 1999), p. 28.
} 
otherwise. Moreover, the Armenian forces had been victorious in the fighting against Azerbaijani forces. Perhaps as a result of these successes and the existence of the Russian military as a stabilizing force in Armenia, the Armenian paramilitary groups did not interfere in Armenian domestic politics.

Another reason in favor of Armenian political stability concerns the distribution of power among senior ministries. Even though the president of Armenia was very powerful, real political power was distributed among senior ministers rather than concentrated entirely in the president's hands. ${ }^{229}$ For instance, it is clear that these powerful ministries played a decisive role in the resignation of Ter-Petrossian in $1998 .^{230}$

The Karabagh conflict has remained the central political issue, indeed the single most important issue, in Armenian politics over the last two decades. There was consensus among the political elites and general public in Armenia and in Karabagh. They believed that the conflict was already resolved and no action was necessary and it was extremely difficult to change the status quo. However, when the Ter-Petrossian government considerably shifted its approach and dropped talk of a political union between Armenia and Karabagh and refused to recognize the self-declared Karabagh government until an agreement was reached between Azerbaijan and the Karabagh Armenians, this led to a tension in his relations with the nationalist political elites in

\footnotetext{
${ }^{229}$ Herzig, 1999, p. 30.

${ }^{230}$ See Stephan H. Astourian, 'From Ter-Petrosian to Kocharian: Leadership Change in Armenia," Berkeley Program in Soviet and Post-Soviet Studies, Working Paper Series, Winter 2000-2001; Jonathan Aves, "Politics, Parties and Presidents in Transcaucasia," Caucasian Regional Studies, 1996, no. 1, http://poli.vub.ac.be/publi/crs/eng/0101-02.htm, p. 6. In his resignation speech, Ter-Petrossian explained "well-known bodies of power demanded by my resignation. Taking into account the fact that the fulfillment of the president's constitutional duties under the current situation is fraught with a real danger of destabilization in the country, I accept that demand and announce my resignation," Armenpress News Agency, "Statement by President of the Republic of Armenia Levon Ter-Petrossian," 4 February 1998.
} 
Armenia and the Karabagh leadership. However, the success of Ter-Petrossian's foreign policy depended on his moderate and pragmatic stance and policies related to the Karabagh issue.

In the second half of the 1990s, the internal political situation in Armenia became unstable, firstly with the resignation of Ter-Petrossian in 1998 and then the assassinations of prime minister, speaker of the parliament and other politicians in the Armenian parliament in October 1999. Prime Minister Vazgen Sarkissian was killed, together with six other politicians, including the parliamentary speaker who was the former Armenian Communist Party General Secretary. ${ }^{231}$

One other issue of importance to the Armenian leadership concerns relations with the Diaspora. While the Armenian government has been keen to promote relations with the Diaspora and to welcome its assistance to Armenia, there have been some tensions. The Diaspora's uncompromising stance in relations with neighboring countries, especially Turkey and Azerbaijan, and its interference in the domestic politics of Armenia irritated the Armenian leadership, especially the Ter-Petrossian government. Such issues, however, were insignificant compared to the Karabagh issue.

Thus, one can say that Armenia achieved relative political stability and the Armenian government fully control led its territory in the early 1990s. Though TerPetrossian was accused of having authoritarian tendencies because of his ban on the opposition party of Dashnak in December 1994, Armenia was, compared to Azerbaijan

\footnotetext{
${ }^{231}$ Oleg Maksimenko, "Terrorists Seize Power in Armenia: Prime Minister and Parliamentary Speaker Are Killed," Kommersant, 28 October 1999, p. 1, in The Current Digest of the Post-Soviet Press, 24 November 1999, vol. 51, no. 43, pp. 10-11.
} 
and Georgia, a model of political stability in the region in the early 1990 s. $^{232}$ Finally, the Karabagh issue provided the focal point. The issue with 'genocide' claim plays an important role of nation and state building processes of Armenia and a reason to different Armenian political groups and elites to come together and unite. Therefore, in the first half of 1990s, because of success in the Karabagh conflict, the Armenian governments did not have any major domestic political crises.

However, this started to change when Ter-Petrossian became ready to compromise on Karabagh after the OSCE Lisbon summit in 1997. The opposition and mainstream political elites turned against Ter-Petrossian and condemned his approach of a compromise solution for Karabagh. Ter-Petrossian was overthrown by nationalist elements in his inner political circles led by his prime minister and former Karabagh leader, Robert Kocharian in $1998 .^{233}$ Therefore, the Karabagh issue became a litmus test for the Armenian political system.

\section{The Legacy of the Past}

Most Armenians were living under the Ottoman Empire until the Ottoman Empire collapsed in 1918. The majority of Armenians were living in different parts of Anatolia and especially in Ottoman major cities, such as Istanbul, but a sizeable minority had also lived across the border in the Russian Empire as well as in its major cities such as Baku, Tbilisi, and Moscow. Some Armenians from the Caucasus and Anatolia were brought to Yerevan during the $19^{\text {th }}$ century by the Russian Tsarist Empire. Therefore, with the First

\footnotetext{
${ }^{232}$ Simon Payaslian, The History of Armenia: From the Origins to the Present, (New York: Palgrave Macmillian, 2007), p. 2004.

${ }^{233}$ Razmik Panossian, "Homeland-Diaspora Relations and Identity Differences," in The Armenians: Past and Present in the Making National Identity, Edmund Herzig and Marina Kurkchiyan, eds., (London: Routledge, 2005), p. 238.
} 
World War and the collapse of the Ottoman Empire, the demographic center of the Armenian population shifted toward Yerevan. After the collapse of Tsarist Russia, there was a brief but chaotic moment. Armenia declared independence which, as was the case in Georgia and Azerbaijan, ended quickly with Armenia's incorporation into the Soviet Union. $^{234}$

The ethno-territorial federal Soviet structure was established in the 1920s. This structure, even though it legitimized ethno-national groups to identify themselves with their own national territories, crushed nationalist interpretations of history until Gorbachev declared the 'glasnost' policy. With the help of 'glasnost', ethno-national groups focused on their national memories consistent with their historical territorial claims in the Soviet Union on each other. ${ }^{235}$ In this context, the Soviet policy of “indigenization" created an ethno-territorial Armenian union republic. The formation of a Soviet Armenian Socialist Union Republic provided a national territorial base for Armenians but this didn't satisfy the Armenian national elite because they claimed Nakhichevan in the west and Karabagh in the east as well as three Georgian districts where large clusters of Armenians were part of Armenia. ${ }^{236}$

Moreover, the legacy of the Armenian past has resulted in the conflation of nation-building with ethno-genesis and has affected understandings of Armenian national identity when combinated with Armenian territorial claims on Azerbaijan and Turkey. Thus, the Armenian elite identify with the contemporary Armenian nation those people

\footnotetext{
${ }^{234}$ Oke, 1988 , p. 84.

${ }^{235}$ Susanne M. Birgerson, After the Breakup of A Multi-Ethnic Empire: Russia, Successor States, and Eurasian Security, (Westport: Praeger, 2002), p. 7.

${ }^{236}$ Richard G. Hovannisian, "Historical Memory and Foreign Relations," in The Legacy of History in Russia and the New States of Eurasia, S. Frederick Starr, ed., (Armonk: M.E. Sharpe, 1994), p. 259.
} 
who once lived on the territories of Eastern Turkey. ${ }^{237}$ In other words, the Armenian elite has understood the importance of its past legacy and Armenian nationalism has become a powerful unifying force for the Armenian nation.

In conclusion, in light of their condition at the beginning of the $20^{\text {th }}$ century, Armenians found a measure of collective security being part of the Soviet Union because Armenia was created as a buffer state between Turkey and Azerbaijan around Yerevan. ${ }^{238}$ This legacy still affects Armenia and Armenian foreign policy. Armenian governments see Russia as a protector, Turkey and Azerbaijan as enemies, and western countries as sharing the same civilization.

\section{b. Threats}

Public opinion in Armenia has always been sensitive on the question of the history of the Armenians in Turkey and Azerbaijan. The irredentist idea over the "territories of historic Armenia" is still quite popular among Armenians in Armenia and especially Diaspora Armenians, and cannot be ignored by any political force in the republic. ${ }^{239}$ This obviously creates tension between Armenia and Turkey as well as between moderate politicians and hardliners within Armenia itself. For example, powerful disagreements emerged between the Armenian leadership under Ter-Petrossian and the leaders of Karabagh after the Lisbon summit of the OSCE. It was at that time that Ter-Petrossian accepted as a basis the plan for a settlement of the Karabagh conflict that

\footnotetext{
${ }^{237}$ Hovannisian, 1994, pp. 251-252.

${ }^{238}$ Henry R. Huttenbach "Chaos in Post-Soviet Caucasia, Crossroads of Empires: In Search of a U.S. Foreign Policy" in The Successor States to the USSR, John W. Blaney, ed., (Washington, D.C.: Congressional Quarterly Inc., 1995), p. 233.

${ }^{239}$ David L. Phillips, Unsilencing the Past: Track Two Diplomacy and Turkish-Armenian Reconciliation, (New York: Berghahn, 2005), p. 20.
} 
had been proposed by the co-chairs of the Minsk group of the OSCE. This plan called for a stage-by-stage resolution. The Karabagh lobby in Armenia and political elites of Karabagh reacted negatively to this idea, fighting for a package option for settling the conflict. $^{240}$

Armenian Prime Minister Robert Kocharian supported the representatives of Karabagh. In addition to that, Kocharian and the Karabagh Armenian leader Arkadii Gukasyan had the support of the Armenian Defense Minister Vazgen Sarkissian and the very influential Yerkrapa Union, which operated under Sarkissian's command and was made up of volunteer fighters who took part in the Karabagh war. It was the Yerkrapah Deputies' group that became the base from which an attack was initiated on TerPetrossian and his parliamentary bloc headed by the APNM. ${ }^{241}$ Beginning in late 1997, Kocharian had begun openly opposing Ter-Petrossian's decision to accept an OSCE proposal for a first stage settlement of the conflict over Karabagh. Ter-Petrossian's willingness to accept the Minsk Group's proposal in Lisbon "as a basis for negotiation" was the critical issue that divided the president from his former allies. Kocharian made clear to Ter-Petrossian that he would not resign if the president attempted to remove him from office and that he had the support of the key "power ministries.",242

\footnotetext{
${ }^{240}$ Stage by stage resolution, the issue would be settled by step by step and each issue would be dealt separately, on the other hand, package solution whereby all controversial issues would be settled by a single framework settlement. See, Richard Giragosian, "Nagorno-Karabagh: International Political Dimensions," in The Making of Nagorno-Karabagh: From Secession to Republic, Levon Chorbajian, ed., (New York: Palgrave, 2001), p. 250.

${ }^{241}$ Stephen H. Astourian, Winter 2000-2001, p. 57.

${ }^{242}$ Aghavni Karakhanian, "Political Culture \& Democracy Building: The Case of Armenia," Political Culture Case Studies, Conflict Studies Research centre, March 2003, p. 7. See also Stephan H. Astourian, 'From Ter-Petrosian to Kocharian: Leadership Change in Armenia," Berkeley Program in Soviet and PostSoviet Studies, Working Paper Series, Winter 2000-2001; Jonathan Aves, "Politics, Parties and Presidents in Transcaucasia," Caucasian Regional Studies, 1996, 1, http://poli.vub.ac.be/publi/crs/eng/0101-02.htm.
} 
Ter-Petrossian himself believes that the Karabagh question was used as a justification to challenge his authority. According to him, the problem goes much deeper and had to do with the foundations of the state and the choice between nationalism and pragmatism. Ter-Petrossian reported that Armenia's government, which relies on the power-wielding (defense, police and security) agencies for support, had demanded that he resign and he had decided to comply with the demand. ${ }^{243}$ Finally, Ter-Petrossian agreed to step down.

\section{External Threats}

Armenian nationalism was built upon historical hostility to Turkey. From the fifteenth century until the early twentieth century, the Ottoman Empire through the millet system, which recognized the religious authority of the Armenian Apostolic Church over the Armenian people, ruled most Armenians. However, the Armenians themselves changed dramatically in the mid-nineteenth century under the influence of the nationalist movement in Europe and the Ottoman Balkans. ${ }^{244}$ For many centuries until national awareness became a force in the $18^{\text {th }}$ and the $19^{\text {th }}$ centuries ethnic and religious tolerance was characteristic of the Ottoman Empire. As the Ottoman Empire started to disintegrate in $19^{\text {th }}$ century, different religious and national groups in the Empire began to seek separation from the Muslim majority and asked assistance from the British and Russian Tsarist Empires. This was the result of an increase in social and political interaction

\footnotetext{
${ }^{243}$ Gamlet Matevosyan, “Armenia Is Left without A President: Parliament Supports Resignation of Levon Ter-Petrosyan," Sevodnya, Feb.5, 1998, p. 3, in The Current Digest of the Soviet Press, 1998, vol.50, no.5, p.18.

${ }^{244}$ Kamuran Gurun, The Armenian File: The Myth of Innocence Exposed, (London: K. Rustem \& Bro., 1985), p. 77 and Oke, 1988, p. 81.
} 
between the Christian minorities' elites with Europeans, which created a sense of secular nationality among many Christian minority elites in the Ottoman Empire. ${ }^{245}$

In 1878 the "Armenian Questions" emerged internationally at the Congress of Berlin and it became an ongoing European issue. In addition, many Armenians had migrated to the Caucasus after Russia's wars with Persia and the Ottoman Empire during the $19^{\text {th }}$ century, and the first major Armenian-Azerbaijani clash occurred in 1905 in the ethnically mixed city of Baku. ${ }^{246}$ After the Bolshevik Revolution in 1917, The Armenian Republic was established in 1918. The Ottoman Empire lost the First World War and was occupied by the Allied forces (Greek, British, Italian and French military forces). The Ottoman Empire was compelled to sign the Sevres Peace Treaty. According to the Treaty, six eastern oblasts (vilayet in Turkish) or regions were given to the Armenian state. ${ }^{247}$ The treaty was dictated by the victorious Allies but never ratified because of the collapse of the Ottoman Empire and the success of the new Turkish Republic against the Armenian forces. ${ }^{248}$

Moreover, the complex demography of the Caucasus made it impossible to create ethnically homogeneous states, and the focus of the Armenian-Azerbaijani conflict shifted from Baku to the area known as Karabagh where, at the time, Armenians formed the majority of the population, although many of them came to this area in the $19^{\text {th }}$ century as immigrants from Anatolia and Iran. The Karabagh was violently contested

\footnotetext{
${ }^{245}$ Oke, 1988 , p. 82.

${ }^{246}$ Tadeusz Swietochowski, Russia and Azerbaijan: A Borderland in Transition, (New York: Columbia University Press, 1995), pp. 39-40.

${ }^{247}$ Oke, 1988, p. 174.

${ }^{248}$ Oke, 1988, pp. 189-190.
} 
through the short period of independence of Armenia and Azerbaijan in the 1920s. The Bolsheviks crushed the independent states of Armenia and Azerbaijan. In 1923, the Allies signed a peace treaty with newly established Turkish Republic in Lausanne and officially abandoned "the Armenian Question". 249

Between Stalin's death and the Gorbachev era, evidence of nationalist expressions in the Caucasus were rare. Within the framework of Communist Party control, however, the major nationalities in the Caucasus consolidated their hold in each of their respective union republics, practicing nation-building for their own nationality and exerting political and cultural dominance over other minority ethnic groups. The system of patronage that became identical with the Soviet bureaucracy from the 1960s to the late 1980s had a nationalist flavor, as members of the political elite would provide rewards and backing to their own clans. ${ }^{250}$

Moreover, even Armenians' attempt to change the status of Karabagh can be traced to the 1930s and various petitions and appeals demanding the transfer of this area to Armenia were made in the 1960 s and 1970 s with no positive response from Moscow. ${ }^{251}$ Thus, during the Soviet Union, the Armenian issue disappeared from political and diplomatic discussions.

However, after seventy years, Karabagh has become again the central security and foreign policy issue of the newly established independent state of Armenia. Indeed it is the single most important issue in Armenian politics since independence. The Karabagh

\footnotetext{
${ }^{249}$ Oke, 1988, pp. 202-203.

${ }^{250}$ Payaslian, 2007, pp. 184-185.

${ }^{251}$ Payaslian, 2007, pp. 184-185.
} 
Armenians declared independence from Azerbaijan and fighting started in $1988 .{ }^{252}$

Fighting between Armenian and Azerbaijani forces intensified with the withdrawal of Soviet forces in early 1992. The Armenian forces, which had support from Armenia and among Diaspora Armenians and supply from the Russian military forces in the region, managed to seize the initiative and score a number of successes, assisted by Azerbaijan's military incompetence, civil unrest, and political upheavals in Azerbaijan. The military successes of 1992 continued in the spring and summer of 1993, when the Armenians took advantage of the collapse of the Azerbaijani army to open a second land corridor at Kelbajar and then to occupy a large part of Azerbaijani territory around Karabagh, including all the land to the south and west of the oblast as far as the Armenian and Iranian borders. ${ }^{253}$

Moreover, the international perception of the Armenians was altered by the massacre of several hundreds Azerbaijani civilians at Khojaly in February 1992 and with the capture of territory outside Karabagh and the creation of tens of thousands of new Azerbaijan refugees. ${ }^{254}$ The Armenians were, therefore, often seen rather as the aggressors by the international community and several United Nations Security Resolutions were passed to condemn the Armenian occupation. ${ }^{255}$

Therefore, the Armenian national movement received a powerful motivation under slogans that spread the struggle for unification with Karabagh as a part of fighting

\footnotetext{
252 Thomas De Waal, Black Garden: Armenia and Azerbaijan through Peace and War, (New York: New York University Press, 2003), p. 10.

${ }^{253}$ De Waal, 2003, pp. 211-213.

${ }^{254}$ De Waal, pp. 170-171.

${ }^{255}$ Cornell, 2001, p. 98 and Giragosian, 2001, p. 251. In April 1993, Resolution 822; in July 1993, Resolution 853; In October 1993, Resolution 874; In November 1993, Resolution 884.
} 
for Armenian irredentist claims to control a historical Armenian homeland. There is harmony among different Armenian political elites and political forces about the status of Karabagh. They believe that Karabagh is a part of Armenia and sooner or later the international community will recognize their claims. In practical terms, Armenia has already formed a common state with Karabagh. Military and political figures from Karabagh, including last two presidents of Armenia, Robert Kocharian and Sergey Sargissian, hold top positions in Armenia. The Karabagh oblast is well connected to the Armenian republic via a highway built with Armenian Diaspora money, it uses Armenian currency, and Armenian youths serve half of their military conscription term in Karabagh. ${ }^{256}$

Since the Karabagh conflict, the gas and oil pipelines and railroads that run through Azerbaijan to Armenia have been blocked. From 1989 on, Azerbaijan has imposed a blockade of road, rail, and energy links with Armenia, supported by Turkey, which also closed its borders with Armenia. The blockade caused severe economic problems for Armenia and led to a sharp energy crisis in 1992-1993. The Azerbaijani and Turkish blockades were most damaging to Armenia in the early 1990s when it lost a direct connection to Russia because of civil wars and instability in Georgia. Another negative consequence of the Karabagh conflict is that Armenia was barred from the

\footnotetext{
${ }^{256}$ See Anna Matveeva, "Nagorno Karabakh: A Straightforward Territorial Conflict," in Searching for Peace in Europe and Eurasia: An Overview of Conflict Prevention and Peacebuilding Activities, Paul Von Tongeren, Hans Van De Veen, and Juliette Verhoeven, eds., (Boulder: Lynne Rienner Publishers, 2002), p. 448; David Rieff, "Case Study in Ethnic Strife," Foreign Affairs, March-April 1997, vol. 76, no. 12, pp. 131-132; Charles King, "The Benefits of Ethnic War: Understanding Eurasia's Unrecognized States," in Nationalism After Communism: Lesson Learned, Alina Mungiu-Pippidi and Ivan Krastev, eds., (Budapest; Central European University Press, 2004), p. 163.
} 
development of Caspian Sea energy-generating resources, which benefit Azerbaijan enormously. ${ }^{257}$

\section{c. Leadership}

The Armenian political system that emerged in 1992 was one of presidential rule similar to the Russian presidential system. After years of power struggles between President Ter-Petrossian and opposition parties over competing constitutional drafts, Armenia's constitution was ratified by the Armenian Parliament in 1994. The constitution created a strong presidency. The current constitution gives the President power over the legislative and judicial branches of government. The presidential system in Armenia reveals several characteristics. First, concentration of power in the executive branch is clearly seen. Second, the separation of powers, and checks and balances between branches of government are missing. Third, the system is distinguished by the privileged status of the presidency in relation to weak and heavily controlled legislative and judicial branches. ${ }^{258}$

The government enjoys unchallenged control over the whole territory of the country though on a local level the old Soviet nomenklatura occupied many of the positions of power, and the institutions of government and civic society were functioning with a certain tension. Ter-Petrossian was accused of undemocratic or even authoritarian tendencies, and the suspension of the Dashnak party and closure of its newspapers in December 1994 as well as allegedly unfair parliamentary elections in 1995 and presidential elections in 1996 provided credence to those accusations, but in comparison

\footnotetext{
${ }^{257}$ Michael P. Croissant, The Armenia-Azerbaijan Conflict: Causes and Implications, (Westport: Praeger, 1998), p. 133.

${ }^{258}$ Herzig, 1999, p. 25; and Payaslian, 2005, p. 200.
} 
with Georgia, Azerbaijan, and many other post-Soviet republics, Armenia appeared a model of political stability and legitimacy until the late 1990s.

\section{Levon Ter-Petrossian (1990-1998)}

The nationalist opposition, although consisting of a number of distinct groups and parties, combined under the umbrella of the Armenian Pan-National Movement (APNM), led by Levon Ter-Petrossian, the former leader of the Karabagh Committee against the communist nomenklatura in 1990. When the APNM won a majority in the elections to the Soviet Parliament, Ter-Petrossian became chairman of the Parliament, and Vazgen Manukian, another former Karabagh Committee member, Prime Minister. The APNM government declared its intention of turning Armenia into a fully independent sovereign state which would integrate Karabagh. ${ }^{259}$ Ter-Petrossian stayed in power eight years, won two elections, even though most international observers considered the elections not free and fair.

Ter-Petrossian, considered a pragmatic self-interest oriented leader by many in the West, said in November 1997, "We must be realistic and understand that the international community will not for long tolerate the situation created around NagornoKarabagh because that is threatening regional cooperation and security as well as the West's oil interests." ${ }^{260}$ He believed that Armenia could not stimulate its economy as long as it is practically cut off from vital supplies. The Armenian political elites and public supported him because of the success of the Karabagh war. However, when he was ready to make compromise to find a peaceful solution to the Karabagh issue, he faced

\footnotetext{
${ }^{259}$ Libaridian, 2004, p. 194.

${ }^{260}$ Steve LeVine, “Armenia Caught in Shifting Tide of World Politics,” New York Times, 29 March 1998.
} 
strong resistance not only from the political opposition but also from within the inner circle of his own administration, including the Prime Minister. On February 6, 1998, Levon Ter-Petrossian was pushed to resign as president of Armenia by his prime minister and other power ministries. Armenia's reputation as the most successful political and economic transformation among the Caucasus states was dealt a blow by the sudden resignation of Ter-Petrossian. ${ }^{261}$

\section{Robert Kocharian (1998-2008)}

According to the Armenian constitution, after the president resigns, the presidency passes to the chairman of the National Assembly. If the speaker of parliament is not capable of executing those duties, the prime minister becomes acting president. In this instance, the National Assembly voted to accept not only Ter-Petrossian's resignation but also the resignation of the speaker of the parliament, Babken Ararktsyan, a TerPetrossian ally. As a result, Armenia's Prime Minister, Robert Kocharian, became acting president and Kocharian's close ally was chosen as the new speaker of the Armenian parliament. ${ }^{262}$ Armenia's Central Electoral Commission allowed Prime Minister Robert Kocharian to run for president, in spite of the fact that he had not fulfilled the citizenship requirements required by the constitution. The legal reasoning was that the citizens of Karabagh, which considers itself a de facto independent state or a de jure part of Azerbaijan, do not have the right to vote in Armenian elections. Kocharian won the

\footnotetext{
${ }^{261}$ Payaslian, 2007, p. 213.

${ }^{262}$ Gamlet Matevosyan and Andrei Smirnov "40 Days of Robert Kocharyan- Former Leader of Karabagh Becomes Temporary President of Armenia," Sevodnya, Feb. 6, 1998, p. 6 in The Current Digest of the Soviet Press, 1998, vol. 50, no.6, p. 17-18; and "Kocharian Takes Over as Acting Armenian President,"

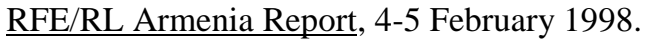


election on 30 March 1998; however, a report of the OSCE described irregularities, including ballot-box stuffing and vote fraud. ${ }^{263}$

Kocharian had headed the Karabagh Armenians from 1992 to 1996. Then he was appointed Armenian prime minister by Ter-Petrossian in March 1997 to ease a political crisis caused by the controversial re-election of Ter-Petrossian in September $1996 .{ }^{264}$ Kocharian, supported by key power ministers, had been at odds with Ter-Petrossian over how to bring to an end the Karabagh conflict with Azerbaijan. Ter-Petrossian had been condemned by Kocharian and other opponents for allegedly being willing to make too many concessions to Azerbaijan.

Kocharian offered guarantees that Armenia would continue to support the Karabagh cause. The Kocharian government received huge financial and material assistance from the Armenian Diaspora in the United States and France. His position on Karabagh, however, hardened. He rejected the OSCE Minsk Group's peace plan. According to the plan, Armenian forces were to withdraw from six occupied districts in Azerbaijan before the resolution of Karabagh's status. Although Kocharian repeated the Armenian pledge to peaceful settlement and met with Azerbaijani President Aliyev, the essence of his position was that the Karabagh conflict would be solved based on a package settlement. In addition to that, he believed that Armenia and Karabagh could grow economically without a resolution, that Armenia would not be negatively affected

\footnotetext{
263 “Hope for Armenia," International Herald Tribune, 7 April 1998.

264 “Kocharian Takes Over as Acting Armenian President," RFE/RL Armenia Report, 4-5 February 1998. See also, Payaslian, 2007, pp. 214-215, and Libaridian, 2004, p. 250.
} 
by isolation from the Azerbaijani oil boom and that Armenia would not have to endure more international isolation than it had in $1992-1993 .^{265}$

\section{d. External Influence}

\section{Russia}

Russian policy on Armenia changed after the failed coup of August 1991 in Moscow. The Azerbaijani leader Ayaz Mutalibov welcomed the coup but the TerPetrossian government rejected the coup and supported Boris Yeltsin, so Yeltsin's government adopted a more pro-Armenian policy in the early 1990s. In addition to that, the Armenian government asked Yeltsin for some Russian forces to remain in Armenia. As a result, a Russian army group, headquartered in Yerevan, has remained in Armenia in line with a 1992 Collective Security Treaty in Tashkent. Several squadrons of Russian warplanes were deployed in Armenia for air defense purposes. Armenia viewed these forces as a guarantee against potential Turkish involvement and in June 1994 offered to regularize Russia's presence in Armenia and provide bases rent-free. ${ }^{266}$

Moreover, Russian forces had been training Armenian fighters from Karabagh and providing direct or indirect military assistance to the Armenian forces in its war against Azerbaijan. Furthermore, in March 1995 president Yeltsin and Ter-Petrossian signed a 25-year treaty, which was the first-ever agreement establishing Russian based on the territory of another state. This legitimized the Russian base at Gyumry, which has helped support Russian military operations in the South Caucasus. ${ }^{267}$ However, the

\footnotetext{
265 “Kocharian Takes Over as Acting Armenian President,” RFE/RL Armenia Report, 4-5 February 1998.

${ }^{266}$ John W. R. Lepingwell, "The Russian Military and Security Policy in the 'New Abroad'," Survival, Autumn 1994, vol. 36, no. 3, p. 77.

${ }^{267}$ Ilya Bulavinov, “ Russian-Armenian Military Treaty: Russia Increases Its Military Presence in the Transcaucaucasus," Kommersant-Daily, 17 March 1995, p. 1, and Armen Khanbabyan, “Cooperation: A
} 
Russian forces play the role rather of a deterring factor due to their small numbers.

Therefore, the Russian base in Armenia is primarily a political rather than a military factor, confirming strategic cooperation between the two states. Thus, Russia's tie with Armenia ensures continued access for Russia in the region.

To summarize, Russia has traditionally had a close relationship with Armenia and Moscow continues to guarantee Armenian security because Moscow's support is the only credible source of a safeguard for Armenia. Armenia is a keen supporter of the Collective Security Treaty signed in Tashkent in 1992. Historical ties with Armenia and the desire to maintain a presence in Caucasus mean that Russia pursues the maintenance of an alliance with Armenia. As Mark Smith writes, Armenia is "bordered by an unreliable ally in the from of Georgia, an uneasy partner in the form of Iran, a hostile regional partner in the form of Turkey, and a declared enemy in the form of Azerbaijan. ${ }^{, 268}$ Consequently, the Russian bases provide security to Armenia; moreover, the necessity of getting supplies to the Russian troops helps weaken Azerbaijan's and Turkey's transport blockade. Thus, the Russian-Armenian political and economic ties and the warm relations were seen as a sign of the two countries' alignment against Turkish and Azerbaijani interests in the region in 1990s.

\section{The United States}

The United States involvement in Armenia and the Armenian issue has a long history. On 8 January 1918 President Woodrow Wilson announced his Fourteen Points

Russian Military Base in Armenia- Treaty Is Signed to Mutual Satisfaction,” Nezavisimiya Gazeta, 18 March 1995, pp. 1-2 in The Current Digest of the Post-Soviet Press, 12 April 1995, vol. XLVII, no. 11, pp. 22-23.

\footnotetext{
${ }^{268}$ Mark Smith, Pax Russica: Russia's Monroe Doctrine, (London: The Royal United Services Institute for Defense Studies, 1993), pp. 55-56.
} 
proposal, with the twelfth one applicable to Armenia. "The Turkish portions of the present Ottoman Empire should be assured a secure sovereignty, but the other nationalities which are now under Turkish rule should be assured an undoubted security of life and an absolutely unmolested opportunity of autonomous development...."269

There were, however, no real connections between Armenia and the United States in the interwar years but at the conclusion of World War II, the Armenia question again surfaced as the Soviet Union included in its territorial demands Kars and Ardahan from Turkey. Interestingly, even as the United States government considered the Soviet Union as its most dangerous enemy during the Cold War, the Armenian National Council in the United States was more hostile towards the Turks and considered the Soviet Union and Soviet military forces as the protector of the Armenians from the Turks. ${ }^{270}$ From the perspective of the governments of the United States, the Cold War was the main concern, and Turkey became a vital part in it, as it joined NATO, was integral to the Truman Doctrine, and held a much more strategic position than did Armenia. ${ }^{271}$

The Armenian Diaspora provided significant morale and kept alive Armenian nationalism during the Cold War years. Therefore, the Armenian Diaspora played a very significant role to unifying Armenians under one cause. While Armenians in Armenia are generally keen on promoting relations with the Diaspora and acting as a homeland for all Armenians, they welcome the substantial donations and investments made by the Diaspora. As Diaspora Armenians became involved in the Karabagh conflict and

\footnotetext{
${ }^{269}$ Michael Gambone, Documents of American Diplomacy: From the American Revolution to the Present, (Westport: Greenwood Press, 2002), p. 180.

${ }^{270}$ Gunter, 1986, pp. 99-100 and Panossian, 2006, pp. 362-363.

${ }^{271}$ William Hale, Turkish Foreign Policy 1774-2000, (London: Frank Cass, 2000), pp. 165-166.
} 
Armenia declared independence, the United States government found itself involved in the affairs of the region and in Armenian politics. The influence of the Armenian lobby on the U.S. policy in the region increased due to the significant Armenian immigrant population in the United States, especially in California and Massachusetts. For instance, an estimated 40 percent of population of the San Fernando Valley in California is of Armenian descent. ${ }^{272}$ After Armenia became an independent state, humanitarian and technical aid flowed abundantly into Armenia; for example, the United States had contributed \$450 million in such aid from 1991 to 1995 , \$105 million in the 1994 fiscal year alone. Prior to 1991 the United States had limited its involvement in the Armenian issue. $^{273}$

First, domestic political concerns have been raised as a motive for the United States actions in the region. For example, a Washington Post column linked the 1996 presidential election to American foreign policy actions. It pointed out the importance of California, with its large Armenian ethnic group, to the election, and that if President Clinton could reach a peace settlement favorable to Armenians, the result would be an inroad into Senator Robert Dole's traditional support among Armenian-Americans. ${ }^{274}$

\footnotetext{
${ }^{272}$ Amanda Covarrubias, “New Era for Glendale Armenians,” Los Angeles Times, 08 August 1995.

${ }^{273}$ At the 25 May 1995 opening of the American Embassy in Armenia, Deputy Secretary of State Strobe Talbott referred to the "...special relationship that has long existed between Armenia and the United States," and stressed that "...we are committed to doing everything we can to preserve and bolster Armenia's newfounded, hard won, and richly deserved independence." He also expressed that "we have provided Armenia with $\$ 450$ million in humanitarian and technical aid. That's more assistance per capita than we give to any of other New Independent States of the former Soviet Union, and it is the third-largest per capita rate in the world, behind only Egypt and Israel." Strobe Talbott, "Celebrating a New Future for Armenia," US Department of State Dispatch, 12 June 1995, vol. 6, no. 24, pp. 498-499.

${ }^{274}$ Robert Dole, “Waiting Too Long to Do What's Right," Washington Report on Middle East Affairs, May 1990, vol. 9, no.1, p. 12.
} 
Furthermore, since 1991 the United States has worked through the OSCE to find a settlement to the Karabagh problem. The official position of the United States on the Karabagh conflict was impartial. U.S. governments have consistenly condemned violence on both sides and attempted to play a mediator role, but the United States has also acted in concert with other major powers in the region. Although the United States has not committed any peacekeeping forces to the conflict, it has been much more heavily involved in diplomatic efforts to resolve the Karabagh conflict. In addition to the United States' involvement in the CSCE and OSCE, Deputy Secretary of State Talbott engaged in shuttle diplomacy, traveling from Moscow to Yerevan to Baku to Ankara, in an attempt to put together an agreement between Armenia and Azerbaijan. ${ }^{275}$

The United States Congress continuously supported Armenia and Karabagh in the 1990s. The Armenian lobby in the United States had demonstrated that it is even more powerful and aggressive than the state of Armenia itself. However, in the second half of the 1990s, oil companies signed contracts with Azerbaijan and began to influence U.S. policy in the region. Still, the oil lobby has been incapable of prevailing over the Armenian lobby's support for Section 907 restrictions on the U.S. aid to Azerbaijan, which suggests that Armenia is being treated favorably in Washington, D.C. ${ }^{276}$

\footnotetext{
${ }^{275}$ Clinton named Talbott as the U.S. Representative and Co-chair of the OSCE Minsk Group. See, Edward Walker, "No War, No Peace in the Caucasus: Contested Sovereignty in Chechnya, Abkhazia, and Karabakh," in Crossroads and Conflict: Security and Foreign Policy in the Caucasus and Central Asia, Gary K. Bertsch, et al., eds., (New York: Routledge, 2000), p. 176.

${ }^{276}$ Thomas Ambrosio, "Entangling Alliances: The Turkish-Israeli Lobbying Partnership and Its Unintented Consequences," in Ethnic Identity Groups and U.S. Foreign Policy, Thomas Ambrosio, ed., (Westport: Praeger, 2002), p. 150.
} 


\section{Turkey}

While Turkey recognized the independence of Armenia, it rejected Armenia's request to establish diplomatic relations, because, in Prime Minister Suleyman Demirel's speech to the Azerbaijani elite, when he was visiting Azerbaijan in May 1992, "Today the blood of our brothers (Azerbaijanis) flows in Karabakh and you should know that Turkey stands behind you and will never abandon you. ${ }^{, 277}$ In August 1992, a Turkish delegation led by Undersecretary Bilgin Unan traveled to Yerevan for talks in improving relations and the possibility of sales of Turkish wheat, and electricity to Armenia. An agreement was announced in September, whereby Armenia would receive 100,000 tons of Turkish wheat some $10 \%$ of its annual grain requirement. Moreover, Turkey and Armenia signed a protocol in November 1992 on the supply of electricity, according to which Turkey was to provide 300 million kilowatt hours of electricity between December 1992 and April 1993. Because of the Azerbaijani blockade and guerilla attacks on the oil and gas pipelines running through Georgia to Armenia, in 1992-1993 the Armenians were suffering a very harsh, cold winter. The residents of Yerevan were cutting down all the trees they could find. The Armenian Diaspora, meanwhile, was very successfully organizing material support and putting pressure on the United States and French governments to send help. ${ }^{278}$

However, these good intentions could not hide reality. Despite negotiations between Turkey and Armenia, the Turkish government rejected establishing diplomatic

\footnotetext{
${ }^{277}$ Svante E. Cornell, “Turkey and Conflict in Nagorno Karabakh: A Delicate Balance,” Middle East Studies, January 1998, vol. 34, no. 1, pp. 63-65.

${ }^{278}$ Fuat Borovali, "The Caucasus within A Historical-Strategic Matrix: Russia, Iran and Turkey,” $\underline{\text { RFE/RL }}$ Research Report, 19 March 1992, pp. 48-50.
} 
relations and fulfilling the agreement with Armenia unless Armenia agreed to drop its claim of "genocide"” and withdraw from Azerbaijani land in Karabagh. ${ }^{279}$ The main reason for the tension was rooted in a clash on the border between Armenia and Nakhichevan, an autonomous region of Azerbaijan which has border with Turkey, in the summer of 1992. Turkey is a guarantor of the autonomous status of Nakhichevan according to the Turkish-Armenian and Soviet-Turkish treaties of 1921 and the Turkish government strongly criticized the Armenian government with its military activity on their border. Matters came to a head in the winter of 1992-93, when Ankara withdrew an offer to supply Armenia with electricity and put a stop to deliveries of grain from being transported across its territory. ${ }^{280}$ The Turkish government fully supported the Azerbaijani side and threatened Armenia with the provision of military assistance to Azerbaijan. Thus, Armenia's concern that its security is threatened by a considerable growth of Turkey's influence in the region is an important factor urging the Armenian state to political and security cooperation with Russia.

\section{e. Conclusion}

Armenia was successfully merged into the old Soviet structures with the new national government. The old nomenklatura and new national ruling elite made a coalition. In other words, the Armenian political elites (both nationalist and Communist) in the early 1990s had a consensus on political goals to establish a nation-state and unite Armenians (including Karabagh Armenians) under this state. This helped a smooth

\footnotetext{
${ }^{279}$ Zeyno Baran, "Turkey and the Caucasus," in Turkish Foreign Policy in Post Cold War Era, Idris Bal, ed., (Boca Raton: Brown Walker Press, 2004), pp. 272-273 and F. Stephen Larrabee and Ian O. Lesser, Turkish Foreign Policy in an Age of Uncertainty, (Santa Monica: RAND, 2003), PP. 106-107.

${ }^{280}$ Aves, 1995, pp. 230-231.
} 
transfer of power and the nationalist elites to consolidate their authorities quickly after they won the first election in 1990. Therefore, the Armenian state was relatively strong. It was an exception in the region because of completing comparatively smooth nation- and state-building process at the same time. Several factors contributed to this process: homogeneity of the Armenian population, assistance of the Armenian diaspora and military success in Karabagh. Thus, Armenia represented the most successful case of consolidating power within a short time among the Caucasus states. This provided Armenia both internal strength and power to eliminate all internal threats to the Armenian government.

Two issues were vital for both internal and external politics: the Karabagh issue and 'genocide' claim. These issues also shaped the threat perception of the Armenian political elite. Until the ceasefire of 1994, the Karabagh issue had rallied different Armenian elites around the single issue and became the symbol of Armenia's internal strength because of the success of Armenian forces in the war. However, in the second half of the 1990s, when the negotiations started and the Armenian leadership was pushed the by international community to make concessions, the Karabagh issue turned into a divisive factor between the Ter-Petrossian government and majority Armenian political elite and threatened Ter-Petrossian's leadership.

Another issue was the genocide claim and the relations between the Armenian diaspora and the Armenian government. The Diaspora's involvement in internal politics of Armenia created a crisis with the Ter-Petrossian government in the middle of the 1990s. But the real influence of the Diaspora involved Armenian relations with neighboring countries, such as Turkey. With respect to the genocide claim as a pivotal 
foreign policy concern, there was a significant difference between the Armenian government and the Diaspora.

Therefore, the Karabagh issue and the Diaspora played a vital role in defining Armenian threat perceptions. Based on their roles, the real threat was external ones coming from neighboring states, Azerbaijan and Turkey. Armenia had a war with Azerbaijan. Armenia also claimed that Turkey was the main potential threat to Armenian sovereignty and statehood.

Because of the successes of the Armenian lobby in the United States, the Armenian government received substantial humanitarian and economic aid. However, the American commitment to Armenia did not go beyond humanitarian and economic aid. Politically and militarily Armenia was dependent on Russia during the 1990s. While Armenia is completely dependent on the flow of military and nonmilitary supplies from Russia and aid from the Armenian Diaspora, the way the Armenian government implemented foreign policy also played a significant role. In other words, the combination of Russian and Diaspora Armenian financial and material aid to the country and the pragmatic approach of the Armenian leadership positively affected Armenia's foreign policy.

Ter-Petrossian, considered a pragmatic self-oriented leader by many scholars, even though he had a nationalist background, like Gamsakhurdia and Elchibey (nationalist leaders who jailed by Soviet authorities because of nationalist activities) turned out to be a very pragmatic leader who shifted his policy position based on circumstances, not on nationalist ideology. Kocharian, however, compared to TerPetrossian, was a more staunch nationalist and tried to achieve goals, such as absorbing 
Karabagh to Armenia and encouraging an admission of 'genocide' from Turkey, that were central to the Armenian nationalist elite's wishes. These differences also affected their perceptions of the international and regional system as well as Armenian foreign policy direction.

\section{Azerbaijan}

\section{a. Strength of State}

As the conflict broadened between Armenians and Azerbaijanis in the late 1980s and the early 1990s, it became clear that the Communist leadership in Azerbaijan was unable to defend its national interests in the face of Armenian claims and military power, backed as it was by Russia and tolerated by the United States. As Azerbaijani state institutions failed to deliver strong leadership in the conflict, diverse political groups and warlords began to emerge with the help of different internal and regional players. For instance, the Azerbaijan Popular Front (APF) was formed in March 1989 as a loose collection of intellectuals, journalists, and researchers at the Academy of Sciences in Baku. ${ }^{281}$ They had inspired a league to boost support for perestroika in the Azerbaijani academic community. But later they decided to address the public at large. The main momentum for the formation of the group was the Karabagh issue. However, in contrast to the popular fronts in the Baltic republics, the APF did not stress a long-term claim for the separation of Azerbaijan from the Soviet Union. It focused instead on boosting the

\footnotetext{
${ }^{281}$ See, Bulletin of Center of Azerbaijan Popular Front Initiative, Baku, 1989, no. 1, pp. 8-9. The APF established by members of Azerbaijani Academy of Sciences, Araz Alizada, Leyla Yunusova, Hikmat Hajizada, Tofiq Gasymov, Isa Gambar, and Ayclin Balayev.
} 
republic's political and economic autonomy within the framework of the Soviet federal state. $^{282}$

After Soviet forces with tanks and artillery entered Baku, killed several hundred people and fully controlled the city in January 1990, the political landscape in Azerbaijan changed. Gorbachev appointed a new Azerbaijan Communist Party leader, Ayaz Mutalibov. The traumatic events of January 1990 prompted a number of intellectuals to join the APF. Mutalibov cracked down on the APF to control the political situation in the country and restore Soviet power in Baku. ${ }^{283}$

In late June 1990 the situation was considered stable enough to set a date for elections to the Supreme Soviet of Azerbaijan. In the first relatively free, multiparty elections, in contrary to Armenia and Georgia, close to 1200 candidates were registered to contest the 350 seats, an average of four candidates per seat. A major surprise of the first round was that Haydar Aliyev, the former Azerbaijan Communist Party Secretary and a Soviet Politburo member in the early 1980s, was elected as a parliamentarian in his native Nakhichevan with nearly 95 percent of the vote in his district. In September 1991, Azerbaijani voters chose not to cast out the Communist Party and its leader, Mutalibov. Despite his success in the previous parliamentary election, Haydar Aliyev was out of the running for the presidency because, regardless of his popularity among the Azerbaijani population, the Mutalibov government had set a sixty-five year age limit to prevent him from becoming the president of the state. ${ }^{284}$

\footnotetext{
${ }^{282}$ Altstadt, 1992, p. 205.

${ }^{283}$ Altstadt, 1992, p. 221.

${ }^{284}$ David Remnick, "Azerbaijanis Cast Ballots for President: Incumbent Unopposed in Soviet Republic," Washington Post, 9 September 1991, p. A17, and Swietochowski, 1995, p. 219.
} 
Since independence was declared in the autumn of 1991, Azerbaijan has been led by five presidents- Ayaz Mutalibov (November 1991-February 1992), Yakub Mamedov (March 1992-May 1992), Abulfez Elchibey (June 1992 -August 1993), Haydar Aliyev (October 1993-2003), and Ilham Aliyev (since October 2003). Changes of leadership have included coups vs. countercoups and fraudulent elections. These leadership changes have had a serious direct impact on the strength of the Azerbaijani state and state structure. Since independence, power struggles between different political factions, groups, and individuals have produced a rapid turnover of political leaders.

Azerbaijan suffered not only from intense political turmoil and but also from the fighting on the Karabagh front in the early 1990s. Its first president, Ayaz Mutalibov, a hard-line communist, was forced to resign following the massacre of Azerbaijani civilians by Armenians in Khojaly in February $1992 .^{285}$ The APF leader Ebulfaz Elchibey, a pro-Turkish nationalist, came to power after the short presidency of Yakup Mamedov, who was the speaker of the Azerbaijani Parliament. Elchibey won an election which was considered free and fair in June $1992 .{ }^{286}$ However, Elchibey failed to control the political structure and process and produced a weak and confused government not capable of carrying out basic functions of statehood and restoring basic law and order. In addition to that, internal splits within the APF affected its ability to govern the state and

\footnotetext{
${ }^{285}$ Vasif Samedov and Sergei Taranov, "Baku Reports on Tradegy in Khodzhaly: Yerevan Considers the Storming of the City a Military Success," Izvestia, 3 March 1992, pp.1-2, in The Current Digest of the Post-Soviet Press, 1 April 1992, vol. XLIV, no. 9, p. 25 and Segei Taranov, "Azerbaijani Units Go On the Offensive: Ayaz Mutalibov's Resignation Intensifies War," Izvestia, 7 March 1992, p. 1, in The Current Digest of the Post-Soviet Press, 8 April 1992, vol. XLIV, no. 10, p. 19. For more the Khojaly Massacre, see TASS International Service, 29 February 1992, and Interfax, 1 March 1992, in FBIS-SOV 92-041, 2 March 1992, p. 64; Goltz, 1998, pp. 85-87; and De Waal, 2003, pp. 170-172.

${ }^{286}$ Georgy Ivanov-Smolensky and Vasif Samedov, "The Results of the Presidnetial Elections in Azerbaijan Have Not Yet Been Made Public, But Most Likely Abulfaz Elchibei Is the Winner," Izvestia, 8 June 1992, p. 1 and "Azerbaijan: Peace, But Still War," Izvestia, 10 June 1992, p. 3 in Current Digest of the PostSoviet Press, 8 July 1992, vol. XLIV, no. 23, pp. 14-16.
} 
control of the political landscape and leadership increasingly passed to more nationalist members of AFP.

Losses in the Karabagh war, asking Russian military forces to leave the country, a readiness to sign oil and gas agreement with Western oil corporations without including Russian and Iranian ones, and Elchibey's intention of uniting South or Iranian Azerbaijan with independent Azerbaijan alienated him from Russia and Iran. ${ }^{287}$ In June 1993, a coup against Elchibey and his government, led by a Russian-backed warlord, colonel Surat Husseinov, resulted in the defeat of the APF. However, Haydar Aliyev quickly monopolized on Husseinov's military coup and emerged as the leader of the country. ${ }^{288}$

\section{Coherence of State Institutions}

Factional political infighting and frequent changes of leaderships have hindered the attempt to establish stable and coherent state institutions. Since independence was declared in the autumn of 1991, five different presidents, and numerous cabinets and ministers, have led Azerbaijan. For example, between September 1991 and March 1992 alone, there were no fewer than five defense ministers, and the post of the chief of the General Staff changed hands six times between September 1991 and October $1992 .^{289}$

\footnotetext{
${ }^{287}$ Shireen T. Hunter, "The Evolution of the Foreign Policy of the Transcaucasian States," in in Crossroads and Conflict: Security and Foreign Policy in the Caucasus and Central Asia, Gary K. Bertsch, et al., eds., (New York: Routledge, 2000), p. 40.

${ }^{288}$ Sokhbet Mamedov, "Geidar Aliyev Urges That The Threat of Civil War Be Eliminated,” Izvestia, 15 June 1993, pp. 1-2 and Georgy Ivanov-Smolensky and Sokhbet Mamedov, " G. Aliyev Promises Azerbaijan Civil Peace," Izvestia, 17 June 1993, pp. 1-2, in The Current Digest of The Post-Soviet Press, 14 July 1993, vol. XLV, no. 24, pp. 2-4. See also, Aidyn Mekhtiyev, "Azerbaijan: Geidar Aliyev's Victory Is Undisputed- Opposition Tried to Interfere with Elections," Nezavisimiya Gazeta, 5 October 1993, p. 2, in The Current Digest of the Post-Soviet Press, 3 November 1993, vol. XLV, no. 40, p. 30.

${ }^{289}$ Richard Woff, “The Armed Forces of Azerbaijan,” Jane's Intelligence Review, October 1993, vol. 5, no. 10, p. 459.
} 
Changes in the political leadership have had a severe impact on the strength of the Azerbaijani state. Firstly, on a number of occasions local Azerbaijani militia leaders have engineered setbacks in Karabagh in order to discredit the existing Azerbaijani leadership, for example the loss of the key town of Shusha without any resistance or the Armenians' ability to establish the very important Ladin "corridor" between Armenia and Karabagh in the first half of 1992. Thus, some of the worst Azerbaijan defeats in Karabagh occurred between 1992 and 1993, when the political struggle between the Azerbaijani government and its opponents in Baku was at its most intense. ${ }^{290}$

One of the most important state institutions is the security force, the army and police. The first Azerbaijani president, Mutalibov, did not support the idea of building up the armed forces. He feared that creating an Azerbaijani national army would simply provide an opportunity for a coup against his leadership. Later, because of defeats in Karabagh and public pressure, he established a national army at the fall of 1991. However, in January 1992, five months after its formation, the Azerbaijan armed forces had only 150 men. Instead, he chose to rely on his close relations with hardliners in Moscow and his expectation that Russian government supports him in any case.

The election of Elchibey in June 1992 was followed by a speeding up to establishing Azerbaijani national army. The Azerbaijan military forces prevailed in small military victories in Karabagh in the summer of $1992 .^{291}$ The reason was that Azerbaijan had for the first time managed to bring together large militia groups that had previously acted mostly independently without any coordination. However, Elchibey’s hope for

\footnotetext{
${ }^{290}$ Aves, 1995, p. 219.

${ }^{291}$ De Waal, 2003, p. 195.
} 
defeating Armenian military forces in Karabagh failed because there had been few Azerbaijani officers in the Soviet army. Therefore, the number of well-trained military officials was limited. Thus, lack of a regular security force created opportunities for the warlords to emerge with their own militia groups in the country. One of the most important of these warlords in Azerbaijan was Colonel Suret Huseyinov, from the second city of Azerbaijan, Gandjia, and who had turned out a large militia unit from his own resources and Russian assistance. Huseyinov's role in Azerbaijani politics was reminiscent of the role that Kitovani played in Georgian politics in the early years of 1990s. ${ }^{292}$ Huseyinov had small successes in Karabagh war at the beginning. But when his forces lost their position in the Karabagh war, Huseyinov decided to use his militia to take power in Baku. Since a series of failures on the Armenian front had weakened the authority of the APF government, Huseyinov and his soldiers moved on Baku, meeting practically no resistance. In the middle of June 1993, Elchibey realized the seriousness of his condition and to avoid civil war he left the capital city for his home village of Keleki in Nakhichevan. ${ }^{293}$ His flight was followed by a new power struggle in Baku between Huseyinov and Aliyev, who had returned to Baku as the speaker of the Azerbaijani Parliament. For a short time in the summer of 1993, there were two ministers of defense,

\footnotetext{
${ }^{292}$ Aves, 1995, p. 219.

${ }^{293}$ Dzhovded Dzhafarov, “Elchibei Doesn’t Want to Return,” Nezavisimiya Gazeta, 24 June 1993, pp. 1-2 and Georgy-Smolensky and Sokhbet Mamedov, "Abulfaz Elchibei Is Removed From Power- The President's Powers Are Transferred to Geidar Aliyev," Izvestia, 26 June 1993, p.1 in The Current Digest of Post-Soviet Press, 21 July 1993, vol. XLV, no. 25, p.18 ; and Cornell, 2001, p. 101.
} 
one loyal to Huseyinov and one loyal to Aliyev. Aliyev managed, however, to strengthen his authority and marginalize Huseyinov quickly. ${ }^{294}$

\section{The Legacy of the Past}

Azerbaijani identity had been consolidated during the period of the Seldjuk Turks in the $11^{\text {th }}$ century and in the $16^{\text {th }}$ century they joined the Shiite branch of Islam. The Azerbaijani land had changed hands several times between the Ottomans and Persians until the Russian invasion of Azerbaijan in the early $19^{\text {th }}$ century. The invasion of Azerbaijan was a long-drawn out affair that continued from 1804 to the Gulistan Treaty and was later completed with the Turkmenchay Treaty of 1828 with Iran. Under these treaties Azerbaijan was divided into two parts. Thus, the two Azerbaijans were put on different paths of political and economic development, with one part open to the influence of Russia and the other to Iranian influence. ${ }^{295}$

Moreover, the twentieth century changed Azerbaijan's place in the international system. Firstly, oil reserves were discovered in the late $19^{\text {th }}$ century, which turned Baku into a booming town. Western investors such as Alfred Nobel entered the country.

Secondly, the first major Armenian-Azerbaijani clash occurred in 1905 in the ethnically mixed city of Baku. ${ }^{296}$ Thirdly, during the turmoil of World War I, Azerbaijan briefly achieved independence. The complex demography of the Caucasus made it impossible to create ethnically homogeneous states. The Karabagh region was contested through the

\footnotetext{
${ }^{294}$ Mekhman Gafarly, “Azerbaijan: Yesterday A Rebel, Today Prime Minister- Surat Guseinov Essentially Receives Total Power," Sevodnya, 2 July 1993, p. 4 in The Current Digest of the Post-Soviet Press, 28 July 1993, vol. XLV, no. 26, pp. 23-24; and Aves, 1995, p. 219.

${ }^{295}$ Brenda Shaffer, Borders and Brethren: Iran and the Challenge of Azerbaijani Identity, (Cambridge: The MIT Press, 2002), pp. 20-22.

${ }^{296}$ Swietochowski, 1995, pp. 39-40.
} 
short period of Azerbaijan's and Armenia's independence. The Paris Peace Conference in 1919 recognized Azerbaijan's claim both to Karabakh and to Zangezur, the latter giving Azerbaijan uninterrupted access to Nakhichevan. ${ }^{297}$ However, the Red Army established the Soviet Republic of Azerbaijan based in Baku in late April 1920. Under threat from the Western powers, the Bolsheviks were anxious to make peace with the new Turkish state, and concluded two treaties with them in 1921 in Kars and Moscow. ${ }^{298}$

As a Commissar of Nationalities, Stalin is credited as separating Karabagh from the rest of Armenia and Nackhichevan from the rest of Azerbaijan, forcing Armenians to cross through Azerbaijani populated areas and Azerbaijanis to cross through Armenian territory in order to maintain their ethnic links. ${ }^{299}$ Thus, Stalin drew the borders between the newly-established Socialist Union Republics, as well as creating ethno-territorial and cultural entities within the union republics. This Soviet legacy affects the independent republics in the Caucasus.

The Soviet era was mostly quiet for Azerbaijan until, in mid-November 1988, the first series of mass rallies started in Baku protesting Armenian violations of Azerbaijani authority in Karabagh. During a mass rally in Baku on 13 January 1990, the Azerbaijani public protested Armenian demands on the Karabagh region. This was ignited a real spark. Rioting broke out and spread to Nakhichevan and later to Karabagh. Fighting in the region turned into full-scale guerrilla warfare between Armenians and Azerbaijanis.

\footnotetext{
${ }^{297}$ Richard G. Hovannisian, The Republic of Armenia: From Versailles to London, 1919-1920, vol.2. (Berkeley: University of California Press, 1982), p. 529; and Audrey L. Altstadt, The Azerbaijani Turks: Power and Identity under Russian Rule, (Stanford: Hoover Institution Press, 1992), p.103.

${ }^{298}$ Ronald G. Suny, Looking toward Ararat: Armenia in Modern History, (Bloomington: Indiana University Press, 1993), p. 130.

${ }^{299}$ Swietochowski, 1995, pp. 106-107.
} 
Gorbachev declared a state of emergency in Azerbaijan and sent Soviet troops as well as the elite troops of the KGB and MVD to Baku. On 19 January, when Soviet troops accompanied with tanks reached the suburbs of Baku, they faced hundreds of protestors forming barricades. Several hundred Azerbaijani civilians died in the clashes. It was such an event that it became part of Azerbaijani collective memory. ${ }^{300}$

Another important legacy of the past is the lack of Azerbaijani military experience under Russian rule. The Azerbaijani army’s poor performance in Karabagh was blamed on the Russian Tsarist and Soviet practice of refusing military training to Muslims. They had been excused from conscript service altogether, as they had been under the Tsarist Russia, but they were usually required to carry out national service in construction battalions under the Soviet Union. This sign of Moscow's distrust did not apply to the Armenians, who with their better training, equipment, and field commanders usually gained the upper hand when fighting against Azerbaijani forces. ${ }^{301}$

\section{b. Threats}

Azerbaijan's condition following independence was typical of a post-colonial society that arrived at independence more through collapse of empire than by a long-term effort of a liberation movement. The typical characteristics were all in place: The Russian Fourth Army was stationed at various points in the country; the country lacked economic self-sufficiency, dependent as it was on the imperial center; and conflicts over state borders and inter-communal ethnic violence were turning into full-fledged warfare. The newly emerging ruling elite, which lacked sufficient political or administrative

\footnotetext{
${ }^{300}$ John-Thor Dahlburg, "Baku Buries Its Dead; Strike Declared to Protest Soviet Military Assault," The Associated Press, 22 January 1990; and Altstadt, 1992, pp. 213-219.

${ }^{301}$ Suny, 1993, p. 218.
} 
experience, was dependent on assistance either from imperial center or from the old Communist ruling elite. ${ }^{302}$

As the ethnic violence between Armenians and Azerbaijanis in Karabagh spread, Azerbaijani governments were overwhelmed by almost one million Azerbaijani refugees from Armenia and Karabagh as well as from the Azerbaijani-Armenian border areas, where a state of war had become reality. The inflow of refugees into Baku from Armenia and Karabagh was starting to affect the political tone of the country. ${ }^{303}$ Moreover, with the collapse of the August coup in Moscow in August 1991 one Union republic after another issued decrees closing their Communist parties and began to declare their independence from the Soviet Union. So the AFP, as the main opposition to the governing Communist Party leadership in Azerbaijan, also began to consider the idea of an independent Azerbaijan. ${ }^{304}$

The most important threat, however, was war between Armenia and Azerbaijan. The clash between Armenians and Azerbaijanis intensified and turned from guerilla war to a full-fledged war. The war first intensified in February 1992. The Armenian forces launched an offensive at Shusha and Lachin aimed at opening a road link to Armenia. At the beginning of this attack, the massacre at the town of Khojali took place, completing

\footnotetext{
${ }^{302}$ Suny, 1993, p. 221. See also, a comparative study on Postcolonial Africa and Post-Soviet Eurasia, Mark R. Beissinger and Crawford Young, eds., Beyond State Crisis? Postcolonial Africa and Post-Soviet Eurasia in Comparative Perspective, (Washington, D.C.: Woodrow Wilson Center Press, 2002).

${ }^{303}$ Shirin Hunter, "Solve the Caucasus Crisis," Christian Science Monitor, 02 June 1992, p. 118 and Niall Fraser et al., "A Conflict Analysis of the Armenian-Azerbaijani Dispute," Journal of Conflict Resolution, December 1990, vol. 34, no. 4, p. 658.

${ }^{304}$ Sefa M. Yurukel, "Nationalism and the Foundation of National Identity in Azerbaijan- Past and Present," in Contrasts and Solutions in the Caucasus, Ole Hoiris and Sefa M. Yurukel, eds., (Aarhus: Aarhus University Press, 1998), p. 269.
} 
the process of ethnic cleansing of the Azerbaijanis from the Karabagh Oblast. ${ }^{305}$ On March 5 the Azerbaijani parliament assembled for a meeting, while outside the building the AFP held a mass demonstration. After two days of intense discussions and sharp accusations, the Azerbaijani Communist Party leader, Mutalibov resigned. ${ }^{306}$

Temporarily, the presidency passed into the hands of Yaqub Mammadov, the speaker of the Supreme Soviet. However, the political instability widened and the Supreme Soviet decided to hold a new election for the presidency but not for parliament. After Armenian forces took Shusha, Mutalibov attempted a coup to reinstate his position. On May 14 the Azerbaijani Supreme Soviet recalled him to the office and canceled the elections. ${ }^{307}$ The APF responded with a massive offensive on the Supreme Soviet's and governmental buildings in Baku. Mutalibov fled, and the Azerbaijani Supreme Soviet closed itself down, transferring its powers to the National Council (the Milli Majlis). Voting took place as originally scheduled, within three months, on June 7 . The favorite in the polls was Abulfaz Elchibey, the chairman of the AFP, a fifty-three-year-old Arabic scholar and former dissident who had spent two years in a Soviet jail. He won the election with 59 percent of the votes. ${ }^{308}$

The winter of 1993 brought a successful Armenian offensive against Azerbaijani towns, resulting in the loss of almost all the region of Agderinsk, the last villages in the

\footnotetext{
${ }^{305}$ Thomas Goltz, “A Town Betrayed: The Killing Ground in Karabakh,” Washington Post, 8 March 1992, and Cornell, 2001, p. 94.

${ }^{306}$ Sergei Taranov, “Azerbaijani Units Go On the Offensive: Ayaz Muttalibov’s Resignation Intensifies War," Izvestia, 7 March 1992, p. 1, in The Current Digest of the Post-Soviet Press, 8 April 1992, vol. XLIV, no. 10, pp. 19-20.

${ }^{307}$ Swietochowski, 1995, p. 219.

${ }^{308}$ Swietochowski, 1995, pp. 219-220.
} 
Lachin corridor, and all the region of Kelbajar, outside Karabagh oblast. ${ }^{309}$ These losses were the result of internal political conflicts among political elites. The government accused Colonel Suret Huseyinov, who had withdrawn his troops from Karabagh to Ganja without Elchibey’s government approval. In that time, Huseyinov enjoyed widespread popularity among the troops under his command because he financed these forces and when the Azerbaijani government discharged Huseyinov from his position, he refused to leave his post. Then Ganja, the second city of Azerbaijan, became the center of opposition for the large groups of APF opponents, who planned to topple the APF's government. $^{310}$

Interestingly, the $104^{\text {th }}$ Russian Airborne Division was also located in Ganja. To prevent Huseyinov's cooperation with the Russian military the APF government demanded the removal of the Russian military division from Azerbaijan. By June 4 the Russian military division had left the city but the Russian military division left behind much of its weapons to Huseyinov's forces. The APF government decided to neutralize Huseyinov's forces. The government operation against the Huseyinov's force failed and Huseyinov, then, started a counter-attack, sending his troops to Baku. There he found support from opposition and a public alienated from the APF government. The APF government offered concessions. While rebel troops moved slowly toward the capital, some of the government ministers negotiated with Huseyinov. The first concession was that three government ministers and Prime Minister Panah Huseyinov were to be

\footnotetext{
${ }^{309}$ Sokhbet Mamedov, "New Flare-Up of War in Azerbaijan; Armenian Shells Burst on Iranian Territory," Izvestia, 27 October 1993, p. 1, in The Current Digest of the Post-Soviet Press, 24 November 1993, vol. XLV, no. 43, p. 23.

${ }^{310}$ Swietochowski, 1995, p. 224.
} 
dismissed, and Haydar Aliyev was brought back to replace Isa Gambar as speaker of the National Parliament. ${ }^{311}$ However, the concessions of the APF government didn't satisfy Huseyinov, who insisted on Elchibey's resignation. On June 18 President Elchibey as expected left the capital to prevent violence, taking refuge in his native village in Nakhichevan. He refused, however, to give up his office. In Baku Huseyinov became prime minister and Haydar Aliyev became the acting head of state. Aliyev strengthened his position in the August 29 referendum on no confidence in Elchibey, and then in the presidential election of October 3, which formally gave him the highest office in the republic. $^{312}$

\section{External Threats}

In the late 1980s, Gorbachev's glasnost and perestroika policies opened the way to Armenian demonstrations and rallied huge crowded on the street in Karabagh as well as in Yerevan. The Azerbaijani government rejected the self-determination demands of the Karabagh Armenians based on Azerbaijan's legal and sovereign rights to the defense of its territorial integrity. Thus the desire for the region to be transferred from Azerbaijani to Armenian authority and the Armenian occupation of Azerbaijani land were at the focal points of the Karabagh conflict. ${ }^{313}$ This issue became the most important external threat to Azerbaijani government and leaders.

\footnotetext{
${ }^{311}$ Aidyn Mekhtiyev, "Azerbaijan: Insurgents Seize Five Districts in the Republic: Geidar Aliyev Continues Talks with the Rebels," Nezavisimaya Gazeta, 15 June 1993, p. 1, in The Current Digest of the Post-Soviet Press, 14 July 1993, vol. XLV, no. 24, p. 1.

${ }^{312}$ Elizabeth Fuller, “Azerbaijan's June Revolution,” RFE/RL Research Report, 13 August 1993, vol. 2, no. 32, pp. 26-27, and Swietochowski, 1995, p. 224.

${ }^{313}$ De Waal, 2003, pp. 125-126.
} 
On February 13, 1988, the Karabagh Armenians, inspired and encouraged by the Armenian political elite and diaspora, began a series of demonstrations in favor of union with Armenia. Moreover, the Karabagh Soviet passed a resolution demanding unification with the Armenian SSR. ${ }^{314}$ The Armenian government assisted the Karabagh Armenians, and issued a plea to the Soviet leadership in Moscow and to the then Soviet leader Mikhail Gorbachev to represent their claims. With the call for transferring Karabagh from Azerbaijan to Armenia rejected by Soviet authorities, the Karabagh Committee of nationalist elites was formed, which included the first president of independent Armenia, Levon Ter-Petrossian, and most of the key political figures in Armenian politics during the 1990s. The old Soviet nomenklatura in Armenia joined the bandwagon of the struggle for Karabagh. ${ }^{315}$

During the Soviet period, Moscow tried to appease the Azerbaijani authorities and Armenian secessionists and dispatched arms to the region. When the authorities in Moscow hesitated and appeared to be confused, the Karabagh movement grew; hundreds of thousands were marching in Yerevan in continuous demonstrations. Azerbaijanis reacted to the Armenian demands by taking to the streets as well. Azerbaijani intellectuals and officials argued that Karabagh was historically a part of their homeland. Therefore, Gorbachev and the Soviet government faced a serious crisis for which neither the Soviet Constitution nor past experience provided much direction to settle a disputed territorial conflict between two union republics in a peaceful way. Each nationality set out selected historic claims for the region. Armenians, who comprised the majority of

\footnotetext{
${ }^{314}$ De Waal, 2003, p. 10.

${ }^{315}$ Gerard J. Libaridian, Modern Armenia: People, Nation, State, (New Brunswick: Transaction Publishers, 2004), pp. 231-232.
} 
most parts of Karabagh, supported their claim with points based on democratic principles and even Leninist notions of self-determination. Azerbaijanis opposed the Armenian claims on the basis of yet another international principle, i.e., defense of territorial integrity (as well as constitutionalism). ${ }^{316}$

After the Russian Federation was established, there was a short-lived confusion of Russian foreign policy. However, as early as 1992, Russia sought to exploit the fact that all three Caucasus states needed Russian assistance to stabilize their countries. Russia perceived these circumstances of the Caucasus states as an opportunity to reach its goals. Russia's prime goal in Azerbaijan was to reestablish Russia's military presence and control the Azerbaijani natural resources and the way these resources go to the world market. Russia made use of the base agreements with Armenia and Georgia in early 1990s to place Azerbaijan under pressure to make some concessions. For example, the Russian Defense Minister, Pavel Grachev, played the Karabagh card first as a stick and later as a carrot to increase pressure on Azerbaijan in 1993-1994. In May 1994 the Defense Ministers of Russia, Armenia and Azerbaijan, and a representative from Karabakh signed a ceasefire agreement. ${ }^{317}$ Grachev was eager to follow with the next step, the deployment of Russian peacekeeping troops to Karabagh. However, Aliyev argued that CSCE/OSCE should have controlled over and participation in the peacekeeping operation in Karabagh. Aliyev's diplomacy was essentially about winning

\footnotetext{
${ }^{316}$ Suny, 1993, p. 134.

${ }^{317}$ Pavel Felgengauer, "Russia Strengthens Its Influence in the Transcaucasus," Sevodnya, 15 June 1994, p. 2, in The Current Digest of Post-Soviet Press, 13 July 1994, vol. XLVI, no. 24, pp. 21-22; and Laszek Buszynski, Russian Foreign Policy after the Cold War, (Westport: Praeger, 1996), pp. 137-138.
} 
time and keeping the issue open until the CSCE/OSCE summit in Budapest in December 1994. That way Aliyev tried to ease Russian pressure from his shoulder. ${ }^{318}$

The first Chechen war in December 1994 that started two weeks after the CSCE (then OSCE) Budapest summit set an additional shadow over plans for the Russian involvement in the Caucasus. ${ }^{319}$ It became clear that Russia would not be able to fully control Azerbaijan, but could nevertheless prevent others from involving the conflict region. When the Russian Foreign Minister Yevgeniy Primakov visited Baku and Yerevan in February and May 1996, he tried to reassert Russia's key role in managing the Karabakh conflict. Although he did not achieve much, the lack of high-level engagement on the Western side and the preoccupation of the OSCE with the Bosnian settlement left Russia as the crucial player in the region and with a broad field for maneuvers. ${ }^{320}$

On the one hand, Moscow carefully cultivated expectations in Azerbaijani political circles that oil money in the near future would enable the rebuilding of a strong army capable of winning back the lost territories. On the other hand, Moscow kept sending signals to Armenia that Russia's military presence was in itself a guarantee; therefore, Armenia could count on unconditional Russian military support. These conflicting signals implied that Russia preferred the Azerbaijani-Armenian conflict continue so that Russia could keep its leverage on them.

\footnotetext{
${ }^{318}$ De Waal, 2003, pp. 237-239.

${ }^{319}$ Elkhan E. Nuriyev, "Conflicts, Caspian Oil, and NATO: Major Pieces of the Caucasus Puzzle," in Croosroads and Conflict: Security and Foreign Policy in the Caucasus and Central Asia, (New York: Routledge, 2000), pp. 143-144.

${ }^{320}$ De Waal, 2003, pp. 261-262.
} 


\section{c. Leadership}

\section{Ayaz Mutalibov (1991-1992)}

The invasion of Baku by the Soviet army on 19-20 January 1990 ended the political career of Abdurrahman Vezirov, the first secretary of the Azerbaijan Communist Party (ACP). Ayaz Mutalibov succeeded Vezirov as the first Secretary of Azerbaijan Communist Party (ACP). ${ }^{321}$ Looking at the ACP's agenda under Mutalibov during the post-January period, one can see that he tried to implement some of the APF's objectives. For instance, Mutalibov emphasized Azerbaijan's territorial integrity by rejecting the abandonment of Karabagh while adopting a cautious line on the possibility of secession from the USSR and attempting to maintain the authority of the ACP. Like the leaders of most of the former Soviet republics, with the exceptions of the Baltic states, Mutalibov sought to keep the old governing system and relied on the Communist ruling elites for the post-Soviet situation. Behind this clear attempt appeared the assumption that the only way to stay in power was to have support of the old center, Moscow, and the old nomeklatura ruling elites. ${ }^{322}$

On August 19, 1991, the day of the Moscow coup, President Mutalibov was on an official visit to Iran. A report from an Iranian radio broadcast indicated that, during his visit to Iran, he had remarked sympathetically about the Moscow coup and its leaders. He was referred by journalists as having termed these events the "natural consequences of the policies that had brought chaos during the past several years.... We welcome the

\footnotetext{
${ }^{321}$ Altstadt, 1992, p. 216.
}

${ }^{322}$ Altstadt, 1992, pp. 221-222. 
developments in the Soviet Union."323 This remark made Mutalibov's relations with Yeltsin's government worse. He lost his backing in Moscow.

Nevertheless, as his political future was being shaped by the deterioration of the Azerbaijani position in the Karabagh conflict, the conflict became the means for the rise of the nationalist movements such as the AFP. As the situation in Karabagh deteriorated, Mutalibov considered his self-interest more than that of his nation. For that reason he was very slow in organizing a national army. Four defense ministers in five months tackled all manner of deficiencies: a lack of trained military officials and soldiers, arms, uniforms, and a sense of military discipline. Mutalibov was suspected of undermining the formation of the national armed forces for fear that they would challenge his leadership in the defense of the country. ${ }^{324}$ He dispersed the official military units which he thought to be under the APF's influence, with the result that warlords, such as Surat Huseyinov in Ganja, emerged and set up their own private armies. ${ }^{325}$ After Armenian forces captured several strategically important towns in Karabagh, Mutalibov was pressed to resign his position in March 1992. For the interim term, the presidency passed into the hands of Yaqub Mammadov, speaker of the Supreme Soviet and the Milli Majlis scheduled to the presidential election in June. However, Mutalibov attempted a coup to reinstate his position after Armenian forces took the historical town of Shusha, in Karabagh. On May 14, with the help of Russia and his allies in the Azerbaijani Supreme Soviet, he reinstated

\footnotetext{
${ }^{323}$ After Muttalibov returned to Baku the official Azerbaijan information agency quickly issued a rejection that he had ever spoken his endorsement for the Moscow coup attempt. Ronald G. Suny, The Revenge of the Past: Nationalism, Revolution, and the Collapse of the Soviet Union (Stanford: Stanford University Press, 1993), p. 214.

${ }^{324}$ De Waal, 2003, pp. 163-164.

${ }^{325}$ Shireen T. Hunter, The Transcaucasus in Transition: Nation-Building and Conflict, (Washington, D.C.: The Center for Strategic \& International Studies, 1994), pp. 71-72.
} 
himself in the presidential office and canceled the elections. The AFP responded with a massive demonstration in front of the Supreme Soviet and government buildings. Mutalibov could not withstand such pressure and fled the country for Moscow; the Supreme Soviet dissolved itself, transferring its powers to the Milli Majlis. ${ }^{326}$

\section{Abulfaz Elchibey (1992-1993)}

Elchibey, who was at the time of his election the leader of the Azerbaijani Popular Front, was characteristic of the first generation of post-Communist leaders in the former Soviet Union, many of whom were nationalist and idealist former dissidents who ultimately proved to be inexperienced as politicians. Elchibey wanted freedom for Azerbaijan and Azerbaijani society. His pro-Turkish foreign policy at the time was widely misunderstood. He wanted Azerbaijan to follow the Turkish model and establish a secular, pro-Western democracy in Azerbaijani society. Elchibey did not suggest that Turkey should replace Russia as "the elder brother" of the Caucasus. However, it is clear that among all the leaders of the Turkic-populated states that have emerged, none was so publicly pro-Turkish as Elchibey. ${ }^{327}$

When Elchibey came to power, the country was involved in a devastating war with Armenia that created a huge refugee problem and greatly stressed Azerbaijan's economy. Therefore, the Azerbaijani public supported and elected Elchibey to strengthen the economy and to succeed in the war over Karabagh. However, he could not fulfill his

\footnotetext{
${ }^{326}$ Georgy Ivanov-Smolensky, “The Return of Ayaz Muttalibov,” Izvestia, 15 May 1992, p. 1, and "APF Leader Isa Gambarov Will Perform Presidential Duties Until Elections," Izvestia,19 May 1992, p. 1 in The Current Digest of the Post-Soviet Press, 17 June 1992, vol. XLIV, no. 20, p. 10-11. See also, Hunter, 1994, pp. 72-73, and Thomas Goltz, Azerbaijan Diary: A Rogue Reporter's Adventures in an Oil-Rich, WarTorn, Post-Soviet Republic, (Armonk: M.E. Sharpe, 1998), pp. 186-200.

${ }^{327}$ Cornell, 2001, p. 100.
} 
pledges in the face of Azerbaijani bureaucratic corruption and local loyalties as well as the institutional weakness of the state. ${ }^{328}$

There are several reasons why Elchibey fell from grace very quickly. First, Elchibey was an inexperienced and emotional political leader. Elchibey's decision not to dissolve the Milli Majlis and delay new parliamentary elections negatively affected his presidency. He feared that a new parliamentary election might affect Azerbaijan's ability to fight effectively in Karabagh. Yet by not holding parliamentary elections, he was denied the political legitimacy needed to resist the Moscow-backed coup that forced him out of office only one year after being elected president. A second reason for his fall was his delay in negotiating an agreement to develop the massive oil fields off the coast of the Caspian Sea. The third was the February 1993 decision of the United States Congress to impose a ban on all United States government aid to Azerbaijan. The pro-Turkish and pro-Western Elchibey thus lost public support for his policy of rapprochement to with the major western powers. The fourth reason was that Russia was openly threatening the Elchibey government, saying that if it did not agree to a deal favorable to Russia, Russia would allow the Armenians to take this or that city in Azerbaijan. This explains in part why Elchibey was so eager to drive out all Russian troops on Azerbaijani territory. Elchibey felt that the sooner Russian troops were out of the country, the sooner the conflict would be resolved. ${ }^{329}$

Finally, it was the deteriorating conditions at Karabagh that hastened Elchibey's fall, especially the loss of the district of Kelbajar in the spring of 1993. When Huseyinov

\footnotetext{
${ }^{328}$ Elizabeth Fuller, “Azerbaijan's June Revolution,” RF/RL Research Report, 13 August 1993, vol. 2, no. 32, pp. 24-29.

${ }^{329}$ De Waal, 2003, p. 233.
} 
rebelled against Elchibey’s government, Elchibey realized that Huseyinov had close relations with the Russian military. Thus, Elchibey feared that resisting him would lead to a bloody civil war of the kind that had brought Georgia to near anarchy after the fall of Gamsakhurdia in Georgia. By not defending his presidency, however, he lost not only his personal authority but also his credibility in eyes of the public and political elites. As a result, Haydar Aliyev, the former CPSU first secretary in Azerbaijan and one-time member of the CPSU Politburo, was able to take power and gather support for his more authoritarian leadership style.

\section{Haydar Aliyev (1993-2003)}

Haydar Aliyev was a well-known political leader in Azerbaijan before he became the president of independent Azerbaijan. He had worked as a KGB General, an Interior Minister, and as the Azerbaijan Communist Party General Secretary long time before he became a member of the Soviet Communist Party Politburo in 1982. In the fall of 1987 Aliyev was forced to resign from his Soviet Communist Party Politburo position because Gorbachev considered him as one of Brezhnev's entourage. ${ }^{330}$ Interestingly, 25 days after Aliyev was pushed aside, the Karabagh problem surfaced on the political scene.

In 1990, Aliyev reemerged as a viable political player. In the Azerbaijani parliamentary election of that year, Aliyev was elected in his native Nakhichevan with nearly 95 percent in his district. He became one of the opposition leaders who opposed both the Communist Party-led and AFP-led governments in the early 1990s. Aliyev called for the removal of the top-level members of the Communist Party of Azerbaijan because of their cooperation with the hardliners who tried to conduct a coup in Moscow

\footnotetext{
${ }^{330}$ Charles Van Der Leeuw, Azerbaijan: A Quest for Identity, (Surrey: Curzon, 2000), pp. 131- 132.
} 
in August 1991. Aliyev left the ranks of the Communist Party and called for an end to the Communist monopoly of power in the country. ${ }^{331}$ He also opposed the APF government and its policies. He dismissed them as inexperienced intellectuals who had little understanding of reality.

When Elchibey left Baku for Nakhchivan after Surat Huseyinov's successful coup in the summer of 1993, Aliyev found an opportunity to take power. The first year of the Aliyev presidency saw no vital changes in the Karabagh war, but the major development of this period became the conclusion of the oil deal. After long and difficult negotiations, an agreement known as "the contract of the century" was signed on September 20, 1994, in Baku. ${ }^{332}$ A thirty-year deal valued at more than seven billion dollars was concluded with an enlarged consortium of foreign companies - four American (Amoco, Unocal, Pennzoil, McDermott), and one each of British (British Petroleum), Norwegian (Statoil), Turkish (TPAO), Saudi Arabia (Delta), and Russian (Lukoil). ${ }^{333}$ When Aliyev came to power, he canceled the oil deal agreed to by the Elchibey government. In the new deal, there was no decision as to pipeline routes. As an alternative to its construction in Turkey there was the possibility of the line passing through Russian territory. Similarly, the

\footnotetext{
${ }^{331}$ Suny, 1993, p. 215.

${ }^{332}$ Emil Pain, a member of the Russian Presidential Council, is believed to have coined the term "Contract of Century"; some translate it as Deal of the Century. See ITAR-TASS, 9 October 1994, in FBIS-SOV, \#94-196, 11 October 1994, p. 18. See also, John Maresca, “The New Silk Road," Wall Street Journal, 26 January 1995, and Hugh Pope, "Great Game II: Oil Companies Rush into the Caucasus to Tap the Caspian,” The Wall Street Journal, 25 April 1997.

${ }^{333}$ John Roberts, "Pipeline Politics," in The Caspian: Politics, Energy and Security, Shirin Akiner, ed., (New York: Routledge, 2004), pp. 81-82. See also, Steve LeVine, Oil and the Glory: The Pursuit of Empire and Fortune on the Caspian Sea, (New York: Random House, 2007), especially pages 218-235.
} 
addition of a Russian company in the international consortium was understood as a bribe to appease Russian objections. ${ }^{334}$

Within less than two weeks of the contract being signed, Azerbaijan experienced a new political crisis. The power-sharing arrangement between Aliyev and Huseyinov had been problematic from the start, and the basic tensions came into the open when Aliyev, after signing the oil agreement, was away from the country for the United Nations General Assembly meeting. Early in October two ranking officials linked to Aliyev were assassinated in Baku. Upon his return, on October 4 came the announcement that a military coup had been attempted with its center in Ganja. Aliyev declared emergency rule for sixty days, and dismissed Huseyinov from the position of prime minister. A mass meeting in Baku demonstrated popular support for Aliyev. Aliyev came to be seen as the champion of Azerbaijani national interests. ${ }^{335}$

Aliyev did not fulfill Moscow's hopes that he would prove considerably more pro-Russian and pro-CIS than his predecessor. Instead, although Aliyev was more careful and cautious in his approach to Russia and despite his repeated declaration that Russia was not to blame for all of Azerbaijan's problems, he refused to allow Russian military bases in the country. ${ }^{336}$ He tried to appease Russia in the beginning by joining the CIS soon after he came to power but having realized that a more friendly approach to Russia had brought no benefits in terms of support in Azerbaijan's war effort in Karabagh and his regime, Aliyev returned to more or less the same policy towards Russia as Elchibey.

\footnotetext{
${ }^{334}$ LeVine, 2007, p. 192.

${ }^{335}$ Goltz, 1998, p. 487.

${ }^{336}$ Sokhbet Mamedov, “Azerbaijan Opposes Establishment of Russian Military Bases On Its Territory," Izvestia, 7 April 1994, p. 3, in The Current Digest of Post-Soviet Press, 4 May 1994, vol. XLVI, no. 14, p.4.
} 
Unlike Elchibey, however, he moved to resolve the oil question, signing the "contract of the century" with eight western oil companies after giving Russia's Lukoil a ten percent interest in the consortium.

The big difference between Elchibey and Aliyev was the latter's recognition that the West did not really care about Azerbaijan's needs. Nor did the West really care that Azerbaijan's territorial integrity had been threatened by the Armenian forces in Karabagh and the occupation of almost 20 percent of Azerbaijan's territory by the Armenians. Much more important was oil. As a self-interested and experienced politician familiar with the principles of realpolitik, Aliyev played the oil card. As a result, despite his authoritarian way of governing Azerbaijan, he secured the support of the Western major powers for his regime.

\section{d. External Influence}

\section{Russia}

In the early nineteenth century Russia established direct control over the South Caucasus. As was typical of imperial authority, the borders of the newly annexed region were drawn to fit Russia's strategic needs but for Azerbaijan the Russian imperial control meant division of the land and its people between Russia and Iran. The two Azerbaijans were put on different paths of political and economic development, with one part opened to the influences of Russia. When the Soviet Union fully controlled the South Caucasus in the early 1920s, Stalin, as the Commissar of Nationalities, decided to draw the borders between newly established union republics to create interdependence between the 
republics that would feel bound to remain in the Soviet Union despite the strong nationalistic feelings among the Caucasian nations. ${ }^{337}$

However, after the Soviet Union collapsed, Russia pursued its own interests in the Caucasus in which Russia perceived the Caucasus, including Azerbaijan, as a part of what it terms the 'Near Abroad'. ${ }^{338}$ Russia's interest lies in two main areas. Firstly, Russia sought to reestablish control over the borders of the CIS. Thus, it desired having troops posted in Azerbaijan and remained in Georgia, as it did in Armenia. Secondly, Russia tried to gain control over Azerbaijan's oil resources. This was made very clear by Russia's intense rejection of the Azerbaijan Caspian Oil Consortium (AIOC), signed in Baku in 1994. Kozyrev, then foreign minister of Russia, on the one hand, declared that Moscow did not recognize Azerbaijan's right to exploitation of the Caspian shelf oil fields. On the other hand, energy lobbies in Russia led by then prime minister, Victor Chernomydin tried to obtain a share of the Azerbaijani oil reserve. ${ }^{339}$

With respect to the Karabagh conflict, Russia preferred only a Russian mediation, i.e., not to have the Minsk process of the OSCE. Armenia, too, favored this solution, whereas Azerbaijan refused to accept a peacekeeping mission including only Russian

\footnotetext{
${ }^{337}$ See Shaffer, 2002; Altstadt, 1992; Swietochowski, 1995.

${ }^{338}$ As Swietochowski called: “An empire does not die easily, especially if it locates across the geopolitical center of Eurasia and the relationship of forces evokes the image of a shark among sardines. But while the pendulum swings back, it does not return to the same point. The conditions that brought the Soviet Union toward decolonization still get hold of, and former nomenklatura rulers reemerge on the scene, but in a changed and new situation. In the past, when the process of imperial restoration from the time of troubles was under way in the years from 1917 to 1923, the empire did come back, but in a different form and at the price of national consolidation of its subject peoples." Swietochowski, 1995. p.234. More information about 'Near Abroad' see, Bertil Nygren, The Rebuilding of Greater Russia: Putin's Foreign Policy towards the CIS Countries, (New York: Routledge, 2008); Rick Fawn, Realignments in Russian Foreign Policy, (London: Frank Cass, 2003); and Lena Jonson, Vladimir Putin and Central Asia: The Shaping of Russian Foreign Policy, (London: I.B.Taurus, 2004).

${ }^{339}$ Barylski, 1995, p. 223.
} 
forces, fearing that Russian control of the peacekeepers could provide leverage to Russia to interfere in the domestic politics of Azerbaijan.

It is obvious that Russia benefited from the instability and internal political fighting among Azerbaijani political elites in Baku during the 1990s and expected that chaos could drive Azerbaijan toward close ties with Moscow. Therefore, Russia, as an important external actor in Azerbaijan was in a position to exercise influence to both Azerbaijani domestic and foreign policy. For example, Russian troops stationed in Ganja were involved in aiding Huseyinov's paramilitary forces to displace the Elchibey government. Similarly, when Chechen fighters fled to Azerbaijan, Russia warned Baku not to provide supplies and a safe haven to them. When Azerbaijan continued to do so, Russia sealed its border with Azerbaijan and imposed a blockade on it. ${ }^{340}$ These actions strongly indicate Moscow's ability to exercise influence on Azerbaijan. At the beginning of his presidency Aliyev had considered Russia to be the only hope for solving the Karabagh conflict and therefore he accepted to bring Azerbaijan back into the CIS was a necessary step, but he refused to have Russian troops return to Azerbaijan.

\section{The United States}

In the early 1990s Western views regarding the events in the Caucasus had been determined primarily by a concern not to undermine friendly leaderships in the Soviet Union and Russian Federation, Gorbachev and later Yeltsin. Therefore, most Western media portrayed Moscow's decision to send the troops into Azerbaijan in January 1990 as an attempt to stop the ethnic conflict and prevent a bloodbath. ${ }^{341}$ The western media

\footnotetext{
${ }^{340}$ Cornell, 2001, pp. 237-238.

${ }^{341}$ For example, "Mr. Gorbachev had little choice but to send troops into Baku, the Soviet Union's fifth largest city. They were needed not just to stop the increasingly bloody civil war between Azerbaijanis and
} 
coverage was considered to be unfriendly to the Azerbaijanis. Reactions from western major powers mirrored the media coverage. For example, the United States State Department conveyed acceptance of the Soviet military intervention in Baku with a justification that it was saving lives jeopardized by the ethnic conflict. ${ }^{342}$ Western media and governments generally made no reference to the much larger number of Azerbaijani lives lost due to the actions of Soviet troops. ${ }^{343}$ For instance, Senator Claiborne Pell, then chairman of the Senate Foreign Relations Committee, stated that Karabagh should be given to Armenia. There was also a letter signed by 28 members of the U.S. Congress and addressed to Gorbachev, demanding that the "unjust administrative policy of the Azerbaijanis in Nagorno-Karabagh is ended." ${ }^{344}$ Moreover, the Congressional Resolution of 17 February 1993, which ended all except humanitarian aid to Azerbaijan in response to the blockade of Armenia, seemed to align the United States government with Armenia against Azerbaijan and Turkey. ${ }^{345}$

Furthermore, the United States sought to push for a solution, acting through the CSCE/OSCE, for the Karabagh problem. But this organization was very slow in seizing opportunities and ineffective in convincing the conflicting sides to agree to the final solution because of its rule for taking decisions on the basis of the consensus of its

Armenians but also to block a concerted attempt by the anticommunist Azerbaijan Popular Front to seize power in the republic" stated in the Economist. See, "Gorbachev's Unwinnable War," The Economist, 27 January 1990, vol. 314, no. 7639, p. 47. See Goltz, 1998, p. 12 and LeVine, 2007, p. 147.

${ }^{342}$ Swietochowski, 1995, pp. 207-208.

${ }^{343}$ Suny, 1993, p. 207.

${ }^{344}$ Francis X. Clines, "Clamor in the East; Moscow Protests to U.S. over 'Interfering' on Armenia by a Senate Panel,” New York Times, 20 November 1989.

${ }^{345}$ Thomas Ambrosio, "Entangling Alliances: The Turkish-Israeli Lobbying Partnership and Its Unintented Consequences," in Ethnic Identity Groups and U.S. Foreign Policy, Thomas Ambrosio, ed., (Westport: Praeger, 2000), p. 150. 
members. The CSCE convened a peace conference in March 1992 in Minsk and then proceeded with several rounds of preliminary talks in the so called Minsk Group (Armenia, Azerbaijan, Belarus, Czech Republic, France, Germany, Italy, Russia, Sweden, Turkey and the United States) which hesitated over the question of the status of the delegation from Karabagh. Thus, the United States became one of the co-chairs of Minsk group. In addition to that, the State Department appointed a special representative to deal with the Karabagh issue and lead to negotiations between Armenia and Azerbaijan. For example, the United States used a closed-door diplomacy and brought leaders of Armenia and Azerbaijan together in Key West, Florida to discuss the problem in $2001 .^{346}$

In the latter half of the 1990s, American policy towards Azerbaijan started to shift because of two reasons: United States policy to Russia, the 'Russia-first Policy', which recognized Russian sphere of influence in former Soviet Union changed and an oil contract was signed with the major Western oil corporations. Azerbaijan therefore became a test of Russian intentions and Western desires to get involved in the regional politics. However, oil has not intensified Washington's interest in finding an agreement and the oil lobby has so far been unable to overcome the Armenian lobby's support for Section 907 restrictions on US aid to Azerbaijan. It is clear that Armenia was being treated favorably in Washington, D.C. during 1990s, especially in the Congress.

\section{Turkey}

Turkey was the first country to recognize Azerbaijan's independence.

Historically Russia and Turkey have long competed for influence in Azerbaijan. For noticeable geographical and cultural reasons, Azerbaijan forms the principal link between Turkey and Central Asia. Azerbaijan, with its Turkic-speaking population, is Turkey's

\footnotetext{
${ }^{346}$ De Waal, 2003, p. 4.
} 
stronghold in the Caucasus. The different geopolitical interests of Turkey and Russia in the region pose a clash of interests and potential threats to each other. For example, Seyfi Tashan, Director of the Turkish Foreign Policy Institute, said that "our interest is to have this area as a buffer zone and their interest is to have this as a forward base." ${ }^{347}$

The Turkish public reacted strongly to the Baku massacre in January 1990. However, the Turkish government's first response was to keep a proper distance from the Soviet Union's domestic problem. The Turkish President Turgut Ozal, then visiting the United States, declared in an informal way that the Azerbaijanis "are Shi'ites, we are Sunnis," and for that reason of more concern to Iran than to Turkey. Turkish public reaction, by contrast, emphasized the ethnic and national character of the Azerbaijani people. Most Turkish newspapers pronounced their sympathy and moral support for the Azerbaijani people and emphasized the "indestructible ties between Azerbaijan and Turkey based on common race, language, and culture."348 The Turkish government felt under pressure to take a more supportive position to the Azerbaijanis from the Turkish public. The public pressure included mass demonstrations of solidarity with Azerbaijan in Istanbul, Ankara, and Eastern Anatolia, where a large part of the population was of Azerbaijani descent. ${ }^{349}$

Moreover, in 1992 and 1993, the Turkish public was shocked by reported massacres of Azerbaijanis by Armenian militias in Karabagh. The events received extensive coverage in the Turkish press, and President Turgut Ozal warned the

\footnotetext{
${ }^{347}$ Daniel Sneider, "Big-Power Rivalry in the Caucasus," Christian Science Monitor, 22 July 1993, p. 2.

${ }^{348}$ Later, he would claim that his statement was misunderstood and misinterpreted; nevertheless, he reiterated, "these are internal affairs of the Soviet Union. It is impossible for us to interfere." See, Swietochowski, 1995, pp. 208-209.

${ }^{349}$ Swietochowski, 1995, p.209.
} 
Armenians that Turkey could not simply stand by and watch their occupation of Azerbaijani territory and the killing of Azerbaijanis. When, in May 1992, Armenian attacks were reported on the Azerbaijani enclave of Nakhichevan, the possibility of Turkish military intervention was in fact seriously discussed in Ankara. The Turkish government considered that the 1921 treaties of Kars and Moscow granted Turkey the right to interfere in a conflict on the subject of the status of the Nakhichevan enclave. In response, Marshal Shaposhnikov, the CIS Commander-in-Chief, threatened Turkey with a statement that any Turkish intervention could be lead to a 'Third World War'. 350

In contrast to the Turkish President Ozal, Prime Minister Suleyman Demirel was seriously worried about the burden that involvement in Azerbaijan could put on Turkey's limited resources. Equally, signals from the United States were negative to Turkish involvement to the region because the Clinton administration became concerned by the prospect of Turkey entering into a conflict with Russia over Russian efforts to restore its sphere of influence in the region. Following the death of Turgut Ozal in 1993, Turkey indicated a return to a more passive form of foreign policy toward Azerbaijan-especially since the United States declarations, including President Clinton and deputy secretary of State, Strobe Talbott, made it clear that the United States regarded the "Russia-First Policy" in the Caucasus and Central Asia. ${ }^{351}$ Thus, the new Turkish president, Suleyman

\footnotetext{
${ }^{350}$ Mohiaddin Meshabi, "Russia and the Geopolitics of the Muslim South," in Central Asia and the Caucasus after the Soviet Union, Mohiaddin Meshabi, ed., (Gainsville: University of Florida Press, 1994), p. 299.

${ }^{351}$ Lena Jonson, "The New Geopolitical Situation in the Caspian Sea," in The Security of the Caspian Sea Region, Gennady Chufrin, ed., (Oxford: Oxford University Press, 2001), p. 19. See also, Laurent Ruseckas, "Turkey and Eurasia: Opportunities and Risks in the Caspian Pipeline Derby," Journal of International Affairs, Fall 2000, vol. 54, no. 1, pp. 217-236.
} 
Demirel pointed out that Turkey was trying to help solve the conflict between Azerbaijan and Armenia and to put an end to the discrimination imposed on Azerbaijan.

Azerbaijani displeasure was heightened with a new Turkish approach to Armenia when the Armenians started successful attacks against Azerbaijani positions in the south of the country in the summer of 1993. During the winter of 1993, Turkey opened its borders to humanitarian aid, which provided Armenia with energy supplies. In the eyes of many Azerbaijanis, this was a strong blow to the credibility and prestige of the Turkish government. For example the Foreign Minister Tofik Kasymov called Ankara's decision to supply Armenia electricity "a stab in the back to Azerbaijan.” The Turkish government canceled the deal and reassured the Azerbaijanis that "Azerbaijan has a priority position in Turkish foreign policy., ${ }^{, 352}$

Moreover, in Turkey the Huseyinov coup against Elchibey in the summer of 1993 stimulated intense debate among the political elite as well as the public in Turkey. Turkish officials were critical of Elchibey for failing to resist the rebels when Huseyinov's forces approached the capital by fleeing the capital city. The Turkish political elites considered Huseyinov as a Russian agent and that his coup harmed Turkish interests in Azerbaijan. The Turkish Foreign Minister Hikmet Cetin clearly demonstrated his disappointments at Elchibey's action, stating that "Elchibey didn't want to have bloodshed, but somebody has to defend legitimacy. Now we are recommending that they call elections as soon as possible. ${ }^{.353}$

\footnotetext{
${ }^{352}$ Elizabeth Fuller, "The Thorny Path to an Armenian-Turkish Rapprochement," RFE/RL Research Report, 19 March 1993, 2, no. 12, p. 50.

${ }^{353}$ Daniel Sneider, "Big-Power Rivalry in the Caucasus," Christian Science Monitor, 22 July 1993, p. 2.
} 
It had been seen clearly that Turkey was in no position to challenge Russia over the Armenian-Azerbaijani conflict and rescue the pro-Turkish Elchibey's regime. ${ }^{354}$ But as the new regime in Baku consolidated control, led by an unstable alliance of Haydar Aliyev and the rebel troop commander Suret Huseyinov, the Turkish government backed Aliyev. ${ }^{355}$ Turkish officials believed that the division of power between Aliyev and Prime Minister Huseyinov was unstable and anticipated a struggle for power between them. Huseyinov and his mentor, the former defense minister Rahim Gaziyev were dismissed by Turkish officials as warlords. In contrast, Turkish officials praised Aliyev, despite his long past in the KGB and Communist Party leadership in Azerbaijan, arguing that he was more able to bring about stable government. ${ }^{356}$

Unlike his predecessor, the late President Turgut Ozal, Demirel preferred the selforiented practical style of Aliyev to the unrealistic nationalism of Elchibey. Thus, Turkish officials believed that, contrary to media accounts depicting Aliyev as Moscow's man, the Azerbaijani leader was his own man. "It is a fact that the Russians didn't like Elchibey and the Iranians didn't like him either," said one foreign ministry source. "But I don't know if there is a love affair between the Russians and Aliyev. He will be more balanced than Elchibey, but I don't think he will be a Russian puppet. Aliyev has experience. He

\footnotetext{
${ }^{354}$ Swietochowski, 1995, pp. 225-226. For Turkish evaluation of the coup, see Gun Kut, "End of Elchibey is the end of the Turkish Model," Cumhuriyet, 24 June 1993.

355 "We recognize Elchibey as the legitimate president of Azerbaijan," says a senior Turkish foreign minister official. "But on the other hand, there is a practical problem. The Azerbaijan Majlis [parliament] is a legitimate, constitutional organ of the country. Whether under duress or not, it has elected Aliyev as its leader... If Aliyev can bring stability to the country, that would be welcome." See, Daniel Sneider, "BigPower Rivalry in the Caucasus," Christian Science Monitor, 22 July 1993, p. 2.

${ }^{356}$ Goltz, 1998, p. 368.
} 
knows what Russia has and what Russia can do. ${ }^{1357}$ This view was widely criticized in the Turkish press, which accused the government of abandoning Elchibey. It was widely believed that Elchibey's removal was engineered by Russia because of his strong antiRussian views, his decision to withdraw from the Russian-led CIS and Russia's continuing interest in restoring its imperial domination over the Caucasus as well as Elchibey's pro-Turkish policies.

\section{Iran}

Iran has deep historic, cultural, and religious ties with Azerbaijan, as well as a long history of friendly coexistence with Armenians. Azerbaijan is very important for Iran because today Iran is one of Azerbaijan's biggest economic partners. However, Azerbaijani relations with Iran are politically fragile. Azerbaijan is afraid of Islamic fundamentalism, and Iran is afraid of the national consciousness of Azerbaijanis in Iran. Moreover, Iran was enthusiastic to offer itself as a political and military model to the newly established independent Azerbaijani state in the early 1990s. By developing strong relations with Azerbaijan, Iran hoped to increase its political influence in the Caucasus. ${ }^{358}$ Therefore, Iran's position toward Azerbaijan had its motivation primarily in an understanding of national and economic interests rather than religious-ideological interests. ${ }^{359}$ However, the relations with Azerbaijan didn’t develop the way Iran expected. Especially under the Elchibey regime, Azerbaijani-Iran relations became strained. Elchibey's rhetoric of unifying Northern Azerbaijan (independent Azerbaijan) and

\footnotetext{
${ }^{357}$ Daniel Sneider, "Big-Power Rivalry in the Caucasus," Christian Science Monitor, 22 July 1993, p. 2. See also, Goltz accounts, pp. 211-13.

${ }^{358}$ Philip Petersen, “Security Policy in post-Soviet Transcaucasia”, European Security, Spring 1994, vol. 3, no. 1, pp. 43-44.

${ }^{359}$ Shaffer, 2002, pp. 185-186.
} 
Southern Azerbaijan (Iranian Azerbaijan) was not welcomed by the Iranian ruling elites. The Iranian government believed that Turkey stood behind Baku and the U.S. stood behind Turkey and Azerbaijan, even though the United States Congress had taken a stand against Azerbaijan in its conflict with Armenia. The Iranian government was worrying about U.S. activities, such as financing separatist groups and encouragement for ethnic uprising in Southern Azerbaijan. Therefore, Iran was concerned to maintain a firm hold on Southern or Iranian Azerbaijan. ${ }^{360}$ Iran also attempted to mediate between Armenia and Azerbaijan several times during the 1990s, but the unwillingness of both Armenia and Azerbaijan and the anti-Iranian containment policy of the United States undermined its mediation attempts.

\section{e. Conclusion}

Azerbaijan experienced considerable internal turmoil during the first half of 1990s: political instability, coups, countercoups, ethnic conflict as well as competition to control the Azerbaijani main asset, oil. There was no basic consensus among Azerbaijani political elites. The Communist nomenklatura and nationalist elites considered each other as enemies. Frequent leadership changes worsened the internal conditions. These factors all had a serious negative impact on the strength of the state and establishing state institutions. Therefore, Azerbaijan became a vulnerable state which had difficulties to deal with both internal and external threats. This was clearly seen in the Karabagh war. Armenian forces defeated Azerbaijani forces and controlled not only Karabagh but also some of Azerbaijani territory beyond Karabagh. Therefore, in the early 1990s, the internal threat to the Azerbaijani state was the main threat. After the consolidation of

\footnotetext{
${ }^{360}$ Shaffer, 2002, p. 186.
} 
power by Aliyev, the ceasefire in Karabagh and signing the oil deal with major western oil corporation in the middle of 1990s, the Azerbaijani government consolidated its authority in the country and concentrated on the secondary external threat.

The main potential external threat was Russia in the second half of the 1990s. Russia wanted only not to control how Azerbaijani oil flowed to the world market but also to establish military bases and to have Russian military forces on Azerbaijani soil. Aliyev regarded this as a challenge to his leadership and Azerbaijani sovereignty. Comparing previous Azerbaijani presidents (Mutalibov and Elchibey), Aliyev was considered as a pragmatic and self-oriented president. His policy first aimed at securing his position and then maximizing Azerbaijani interests. For example, Aliyev made Azerbaijan a member of the CIS and cancelled the oil deal which Russia opposed. In new deal, he invited a Russian oil company to participate, even though he perceived Russia as the potential threat to his authority. Immediately after he consolidated his power at home, however, he shifted his policy again. These were indications of his pragmatic approach and a clear sign of his difference from previous presidents.

On the other hand, the previous president, Elchibey, as a nationalist leader who was jailed by Soviet authority, committed his policy based on his nationalist perceptions of Russian place in the region. He identified Russia as a continuation of centuries of Russian imperialism. For that reason, he was trying to find an alternative to balance Russia in the region. His pro-Turkish stand could be explained based both on seeing Turkey as a strategic partner and an alternative to Russia in the region.

The Azerbaijani government did not have external assistance from major western powers in the first half of the 1990s. The United States, under the influence of the 
Armenian lobby as well as its 'Russia-first policy' not to undermine Russian-American relations, ignored Azerbaijan until major western oil corporations (including American ones) signed the oil deal with Azerbaijan. Therefore, after the deal, the U.S. and major western powers became more involved and active in the region. This also affected Azerbaijani foreign policy in general and Azerbaijani-Russian relations in particular.

\section{Georgia}

\section{a. Strength of State}

In Georgia there was some intense fighting between the opposition and the Communists in 1989. However, the actual change of power took place without violence in 1990. Zviad Gamsakhurdia, the first president of independent Georgia, in the spring of 1991 introduced a political program including laws on freedom of the press, an independent judiciary, political parties, religious and economic freedom, and the separation of powers within a short period after he came power. But the basic democratic significance of these laws was overshadowed and weakened by other less democratic legislation like that on the presidency. This legislation, along with a new constitution, maintained a highly centralized system with immense powers in the hands of the president, such as his right to appoint and dismiss prime ministers, cabinets and high level military officers, or to dissolve parliament, call a referendum and declare a state of emergency and rule by decree. In addition to those, Gamsakhurdia's presidential superiority was extended by his power to veto the laws and decrees passed by the legislatures of the autonomous republics and regions in Georgia. Thus, in an attempt to totally control the government, Gamsakhurdia established a strong presidency. ${ }^{361}$

\footnotetext{
${ }^{361}$ Thomas Goltz, Georgia Diary: A Chronicle of War and Political Chaos in the Post-Soviet Caucasus, (Armonk: M. E. Sharpe, 2006), pp. 5-6; Hunter, 1994, pp. 119-120; and Cornell, 2001, pp. 162-163.
} 
Regardless of the fact that a sizeable majority elected him in May 1991, his authority as president was diminished since he alienated strong political elites and groups, including his former colleagues in the Round Table of the National Liberation Alliance and was accused of having authoritarian tendencies by the Georgian political elite, which feared that it was being marginalized. ${ }^{362}$ The fall of Gamsakhurdia's government in the winter of 1991-92 enhanced the power of the Georgian parliament and political elites and groups that were linked to strong paramilitary groups, particularly Joba Ioseliani's Mkhedrioni (Horsemen) and Tengiz Kitovani’s National Guard.

Shevardnadze's return to Georgia three months after the coup against Gamsakhurdia in March 1992 was regarded as a positive indication that Georgia might have a higher degree of unity to deal with problems of transition. On the other hand, the way in which Shevardnadze came to power and his dependency on the power of the National Guard and Mkhedrioni militias, raised questions about Shevardnadze's ability to fully control the political landscape in Georgia. While the appointment of Kitovani and Ioseliani, the Minister for Defense and a member of the Defense Council, could have been seen as a way of controlling warlords who led their own militias in the completely anarchic condition in which Georgia found itself, the appointments of Kitovani and Ioseliani found them actively involved in Georgian foreign policy and security issues. ${ }^{363}$

The pro-Gamsakhurdia uprising in Mingrelia, a northwestern part of Georgia, reached its peak in the autumn of 1993, with weakening efforts of the Georgian

\footnotetext{
${ }^{362}$ Aves, 1995, p. 215.

${ }^{363}$ David Darchiashvili, "Georgian Defense Policy and Military Reform," in Statehood and Security: Georgia after the Rose Revolution, Bruno Coppieters and Robert Legvold, eds., (Cambridge: The MIT Press, 2005), p. 127.
} 
government forces to stand against the joint offensive of the Abkhazians and their Circassian allies on the capital Sukhumi. Since Georgian forces collapsed and were ousted from Abkhazia, Shevardnadze was forced to agree to ask assistance from Russian military forces in western Georgia against the pro-Gamsakhurdian forces who were moving to Tbilisi. This was one of the most crucial moments of the 1990s in Georgian history, given the absence of a consensus among the Georgian government and political elite as to how to conduct the civil wars. ${ }^{364}$

The Abkhazian separatists started in August 1992 and ended in Georgia's defeat in September 1993 with the loss of the Abkhazian autonomous republic and over 20,000 lives. Thus, the power struggle among political elites in Tbilisi and a more prolonged struggle with Abkhazian separatists crippled Shevardnadze's attempt to reconstruct Georgian state institutions and the Georgian security forces. The wars against Abkhazian and pro-Gamsakhurdia forces increased the power of the paramilitaries, mainly because of a lack of a regular army. Shevardnadze was compelled to enter into a careful balancing act between the two paramilitary leaders, Kitovani and Ioseliani. It was only in May 1993 that he was able to remove Kitovani as Minister of Defense. Kitovani had already refused to obey Shevardnadze's orders a number of times, including the defiance of the latter by starting military operations against the Abkhazian separatists. Ioseliani demonstrated that he was politically more flexible than Kitovani but, despite several efforts by Shevardnadze to incorporate Ioseliani's Mkhedrioni into the Georgian armed forces, he commanded Mkhedrioni forces as his own private army. ${ }^{365}$ While the possibility of

\footnotetext{
${ }^{364}$ Cornell, 2001, pp. 171-172.

${ }^{365}$ Darchiashvili, 2005, p. 127.
} 
violence continued in Abkhazia, South Ossetia and the southern regions populated by Armenians and Azerbaijanis, Shevardnadze needed Ioseliani. Though Ioseliani clashed with Shevardnadze and his government on a number of occasions, at the same time Ioseliani's Mkhedrioni had several times saved Shevardnadze from military defeat.

By the end of 1995, after three years of secessionists' wars, civil conflicts, and economic disaster, there were some indications that Shevardnadze had established full control over the government. With the Russian military presence, Shevardnadze was able to disarm many of the members of the paramilitary groups and brought some measure of stability to Tbilisi. Shevardnadze arrested Kitovani in the winter of 1994-95 and moved against Ioseliani's forces in mid-1995; after an attempt against his life in August 1995, Shevardnadze arrested Ioseliani. ${ }^{366}$

\section{Coherence of State Institutions}

The lack of coherence among the new political institutions and structures meant that Georgia had begun to fall into anarchy before Gamsakhurdia was removed from the presidency at the beginning of 1992. After that, the prevailing political anarchy turned into a very destructive civil war, both between various different political groups, as well as between Georgians and ethnic minorities in Georgia.

The collapse of state structures signified that the Georgians were incapable of pulling together their resources for the civil war. Whatever the level of Russian military assistance to Abkhazia and South Ossetia, the Georgian regular army was bankrupt and weak. Infighting among different political and paramilitary groups and the failure to

\footnotetext{
${ }^{366}$ Christopher Zurcher, “Georgia’s Time of Troubles, 1989-1993,” in Statehood and Security: Georgia after the Rose Revolution, Bruno Coppieters and Robert Legvold, eds., (Cambridge: The MIT Press, 2005), p. 97.
} 
form viable state structures and institutions led not only to the loss of control over an important part of the country by the end of 1993 but also to the break down of basic law and order. While support for Georgian independence in 1991 was nearly unanimous among ethnic Georgians, the political leaders' failure to build legitimate and effective state structures and institutions and their failure to guarantee basic law and order meant that it became almost impossible to rally the population against new external and internal threats. In this respect, Georgia at this time represented an example of a weak state lacking coherent state institutions. ${ }^{367}$

The security forces are very important state institutions because of their role defending the country against external threats and providing law and order in the country. The issue of creating armed forces was discussed after the victory of Gamsakhudia's nationalist "Round Table" bloc in elections to the Supreme Soviet of Georgia at the end of 1990. However, instead of creating a regular army, the number of paramilitary groups soon increased. The result of the emergence of different paramilitary groups associated with different political movements had disastrous consequences. The soldiers became loyal to their militia leaders and suffered from a serious lack of discipline. For instance, the paramilitary groups and the National Guard played a major role in the overthrow of Gamsakhurdia in late 1991. The National Guard soldiers were loyal to their militia leader, Kitovani, rather than the head of state. Moreover, one of the reasons for Gamsakhurdia's demise was Kitovani's refusal to abide by the president's order to break up the National Guard and place the National Guard under the control of the Ministry of

${ }^{367}$ Aves, 1995, p. 216. 
Internal Affairs. ${ }^{368}$ When he took power after the coup at the request of paramilitary leaders, Shevardnadze had only limited control over the militias and the official military forces. Because the militias were involved in initiating and waging the wars in South Ossetia and Abkhazia as well as destroying the pro-Gamsakhurdia insurgency, their political importance had increased over time. This, in turn, made it difficult to restore a stable government and create a reliable system of political control.

Shevardnadze first concentrated on achieving a ceasefire with the South Ossetian separatists. Shevardnadze signed a peace agreement in June 1992 with the South Ossetian leaders that permitted the deployment of a Russian dominated peacekeeping force in the region. After that Shevardnadze eliminated the paramilitary leaders and established full control over the armed forces, he appointed Vardiko Nadibaidze in April 1994 as the Defense Minister, an ethnic Georgian general in the Russian army who had close ties to Russia. Nadibaidze was far more supportive of permitting Russian bases in Georgia than Shevardnadze and had backed Russian President Yeltsin's plan to from a military alliance of members of the CIS as a counter to the expansion of NATO. ${ }^{369}$

Shevardnadze's election to the Georgian presidency in November 1995, with more than $70 \%$ of vote, presented him with a mandate to lead and create opportunities to establish internal political stability and calm after four years of civil war, ethnic conflicts, and political turmoil. There was no credible domestic challenger to Shevardnadze's rule but still conflicts in Abkhazia and South Ossetia, the Russian involvement in the region, and Chechen wars made Shevardnadze look for assistance from the major western powers. Internally, having a weak and incompetent parliament suited Shevardnadze but it

\footnotetext{
${ }^{368}$ Aves, 1995, p. 216.

${ }^{369}$ Darchiashvili, 2005, pp. 130-132.
} 
weakened the coherence of the Georgian state structure and institutions. Externally, regional and international developments created opportunities for Georgia to have a more balanced foreign policy: these include the Caspian pipeline through Georgia, the September 11, 2001, terror attack in the USA, and the United States invasion and occupation of Iraq.

\section{The Legacy of the Past}

The most serious development which has shaped Georgian politics today occurred at the beginning of the $19^{\text {th }}$ century. At this time, the Russian Tsarist Empire expanded its empire to the Caucasus. The Russian Tsarist Empire annexed eastern Georgia (Kartli and Kakheti kingdom) in 1801 and placed Georgia under Russian authority. Georgian national identity was thus nurtured under Tsarist rule.

After the Bolsheviks came to power in Russia, most of the Caucasus societies and political elites refused to recognize the Bolshevik government. On May 26, 1918, Georgia declared its independence under the Social Democratic Party leadership. During the next two years, the Georgian government and parliament adopted different laws and established their own legal, political and administrative system. Georgia was recognized as an independent state by Weimar Germany. However, the Georgian republic did not last long. In February 1921 Soviet forces, having defeated Georgian forces, invaded Georgia and established the Georgian Soviet Socialist Republic. At first, Georgia was part of the Transcaucasian Soviet Socialist Federative Republic and then became a member of the USSR. ${ }^{370}$

\footnotetext{
${ }^{370}$ Ronald G. Suny, The Making of the Georgian Nation, $2^{\text {nd }}$ edition, (Bloomington: Indiana University Press, 1994), especially between 185 and 208 pages.
} 
During the 1970s, dissident nationalism became a phenomenon in Georgia as intellectuals reacted to the corruption of the system and issues related to Georgian literature and language. Among these dissidents was Zviad Gamsakhurdia, son of the prominent writer Konstantin Gamsakhurdia. Zviad Gamsakhurdia monitored human rights violations under the Helsinki Accords and was arrested in the 1970s for disseminating anti-Soviet propaganda. In 1987, Gamsakhurdia established the Ilia Chavchavadze Society, a nationalist group that was strongly anti-Soviet. ${ }^{371}$ Shevardnadze also emerged as an important political actor in the 1970s. He held different high governmental positions, first as Interior Minister, and then General Secretary of the Georgian Communist Party in the 1970s and early 1980s. Thus, Zviad Gamsakhurdia became a longtime rival of Shevardnadze. ${ }^{372}$

The turning point for Georgia came on 9 April, 1989, when the Soviet army brutally broke up a demonstration in Tbilisi. Troops called in to restore order killed 20 Georgians and the events became a subject of intense discussion in the Congress of People's Deputies in Georgia. As the result of this event, the Communist Party was discredited and nationalist groups became the main actors of the political life in Georgia. Georgia officially declared independence on April 9, $1991 .^{373}$

Abkhazia was created as a separate union republic in 1921, but was joined to Georgia in a confederal union treaty later the same year. Abkhazia's status was reduced in 1931 as a result of its integration into the Georgian union republic as an autonomous

\footnotetext{
${ }^{371}$ Suny, 1994, pp. 308-309.

${ }^{372}$ Carolyn M. Ekedahl and Melvin A. Goodman, The Wars of Eduard Shevardnadze, (University Park: The Pennsylvania State University Press, 1997), p. 23.

${ }^{373}$ Irakly Areshidze, Democracy and Autocracy in Eurasia: Georgia in Transition, (East Lansing: Michigan State University Press, 2007), p. 19.
} 
republic. Moreover, the Abkhazians saw Stalin's nationality policy to be a sign of postWorld War II migration of large numbers of Georgians into Abkhazia. Because of the inflow of Georgians since the 1920s, the Abkhazians became a minority in their own homeland. Numbering just 93,000, they composed just 1.8 percent of Georgia's population in 1989, and 17 percent of the population of Abkhazia itself, with the rest, consisting of ethnic Georgians, accounting for 45 percent, and Armenians and Russians, accounting for a further 30 percent. $^{374}$

Furthermore, in the late 1980s, Abkhazians living in the Abkhazian autonomous republic of Georgia demanded a republic of their own and Georgians, in turn, demanded independence from the USSR in a series of mass demonstrations and hunger strikes in Sukhumi and Tbilisi. Georgian-Russian relations worsened after 1989, as did relations between Georgia and Abkhazia, with a power-sharing conflict to follow. ${ }^{375}$ Therefore, the conflict in Abkhazia stems from both the inheritance of the Soviet nationalities policy and the rise of ethnic nationalism during the late 1980s.

Moreover, the conflict in South Ossetia evolved along similar paths as in Abkhazia, with disputed claims to the territory, the Ossetians' fear of assimilation into the Georgian nation, and Ossetian demands to join the Russia Federation. South Ossetia was established as an autonomous region (oblast) within Georgia. While South Ossetia was ruled from Tbilisi and separated from the north of Ossetia, the Georgians considered that South Ossetians were in a privileged situation vis-à-vis other regions of Georgia.

\footnotetext{
${ }^{374}$ Anna Matveeva, "Georgia: Peace Remains Elusive in Ethnic Patchwork," in Searching for Peace in Europe and Eurasia: An Overview of Conflict Prevention and Peacebuilding Activities, ed. by Paul Van Tongeren, et. al, (Boulder: Lynne Rienner Publisher, 2002), p. 416.

${ }^{375}$ Jonathan Wheatley, Georgia from National Awakening to Rose Revolution: Delayed Transition in the Former Soviet Union, (Burlington: Ashgate, 2005), p. 416.
} 
When the revival of Georgian nationalism and Gamsakhurdia's presidency aroused alarm among South Ossetian political elites, they demanded to be part of Russia. ${ }^{376}$

Therefore, the legacy of the past in Georgia can be described in terms of a conflict-ridden ethnic nationalism and deep concern about autonomous political structures. From the late 1980 s to the early 1990s, political actors in the country utilized and manipulated the political opportunities presented by perestroika and exceptional political change. While Georgians were concerned with Russian domination and sought to separate from Russia's sphere of influence, the Abkhazians and Ossetians were motivated by the fear of incorporation into the Georgian nation and demanded either the establishment of their own independent states or accession to the Russian Federation.

\section{b. Threats}

With the breakup of the Soviet Union, the newly independent states and different communities mobilized politically based on their ethno-national and linguistic identities. In the case of Georgia, having multiple ethno-nationalities living within the country, was confronted by serious political and ethnic turmoil that put its newly gained independence into doubt in the shadow in the early 1990s. Conflicts between different political fractions and paramilitaries in Tbilisi and different ethno-nation groups in South Ossetia and in Abkhazia led to civil wars in the country. Abkhazians and Ossetians felt that foreigners were ruling them, while the Georgians saw the desire for independence by Abkhazians and Ossetians as a betrayal of Georgia.

After fighting between different groups and the overthrow of President Gamsakhurdia, the Georgian government was controlled by a weak and volatile coalition of paramilitary leaders, particularly Kitovani and Ioseliani in spring 1992. Kitovani and

\footnotetext{
${ }^{376}$ Areshidze, 2007, p. 22.
} 
Ioseliani invited Shevardnadze to head the state in the hope of securing international recognition and domestic legitimacy. Moreover, in August 1992, the Georgian State Council, which was established by the paramilitary leaders, ordered Georgian military forces, consisting mainly of National Guards and small paramilitaries led by Kitovani, to occupy Abkhazia. Although Shevardnadze was not initially aware of the Georgian forces advancing to Sukhumi, the capital city of Abkhazia, an act that led to full-scale war between Georgia and Abkhazia, he later approved it. ${ }^{377}$ So the ethnic conflict turned into open civil war, when Georgian Defense Minister Kitovani's National Guard forces marched into Abkhazia's capital. Shevardnadze claimed that Kitovani's forces had been sent to stop the "forces" of Gamsakhurdia's militia and gain the release of several Georgian government officials, including Deputy Prime Minister Alexander Kavsadze, who had been kidnapped by Gamsakhurdia's forces. Kitovani's forces, however, marched against the Abkhazian forces led by Vladislav Ardzinba. Several hundred people were killed in Abkhazia in August, and there was more bloodshed in September, when Kitovani's paramilitary forces opened fire on the parliament building in Sukhumi. When Kitovani's troops failed to defeat the Abkhazian separatists, Shevardnadze sent more forces, led by Ioseliani's Mkhedrioni paramilitary against the Abkhazian separatists. In response to the Georgian attack, the Abkhazians mobilized support from the Circassians in the North Caucasus, with Chechen fighters playing an important part in Abkhazia's increased military capacity. The Abkhazians also benefited from Russian military support dispatched through the Russian bases in Abkhazia. Abkhazian forces initiated a counteroffensive and their attack ended with victory in September 1993. The Georgian

\footnotetext{
${ }^{377}$ Ghia Nodia, "Causes and Visions of Conflict in Abkhazia," Berkeley Program in Soviet and Post-Soviet Studies Working Paper Series, Winter 1997-1998, 1997-02, p. 41.
} 
forces and population fled from most of Abkhazia. ${ }^{378}$ The Abkhazian separatists controlled almost all Abkhazia except a small area called Kodori Gorge and the Gali region. A Russian-brokered ceasefire came into effect in December 1993 and lasted through the 1990's, with the exception of fighting in the Kodori Gorge and Gali region. Most observers agree that Russian military support was crucial for the Abkhazian success. The Abkhazian separatists had major supporters in Moscow, including the Vice President Alexander Rutskov and the speaker of the Russian parliament, Chechen-origin Ruslan Khasbulatov. Georgian Minister of State Vazha Lortkpanidze said, "the Abkhaz conflict is a military and political conflict started in order to preserve the Soviet Union, and it is the Russian government that is responsible for it."379

The Abkhazian goal was to make Abkhazia an independent state. In November 1999, the Abkhaz leadership declared independence. The major reason on the Abkhazian side was that there was no desire to enter into a common state with Georgia. The common perception of both the Abkhazian political elites and public was that if integrated into Georgia, the Abkhazians would have a lot to lose, such as security and a dominant political position in Abkhazia. ${ }^{380}$

Another internal conflict is in South Ossetia. The South Ossetian conflict was basically connected to a revitalization of Georgian nationalism under President Gamsakhurdia. South Ossetia demanded reunification with North Ossetia in the Russian Federation in September 1990 and declared sovereignty and called for recognition from

\footnotetext{
${ }^{378}$ Cornell, 2001, p.174, and Edward Mihalkanin, "The Abkhazians: A National Minority in Their Own Homeland," in De Facto States: The Quest for Sovereignty, (London: Routledge, 2004), p. 149.

${ }^{379}$ Elizabeth Fuller, “Quotations of the Week,” RFE/RL Caucasus Report, 1998, 1, p. 44.

${ }^{380}$ Mihalkanin, 2004, pp. 152-154.
} 
Moscow as an independent entity of the USSR. Gamsakhurdia believed the Russians had provoked the South Ossetians and refused to permit South Ossetia's merger with North Ossetia. His government struck back and abolished South Ossetia's autonomous status in December 1990 and fighting broke out between the Ossetian militias supported by the Soviet Interior Ministry troops and the Georgian police and paramilitary groups at the end of 1990. During the next two years, fighting intensified and casualties mounted. It resulted in the expulsion of Georgian forces and people from Tskhinvali, the region's capital. $^{381}$

When Shevardnadze returned to Georgia, he wanted to end the fighting as soon as possible. He was willing to grant autonomy to South Ossetians. He accepted a cease-fire and agreed to Russian participation in a multilateral peacekeeping force. Population exchanges took place: Ossetians from other parts of Georgia moved to South or North Ossetia, and most ethnic Georgians left South Ossetia. ${ }^{382}$ In the summer of 1992, a small peacekeeping force consisting of Russians, South Ossetians, and Georgians was deployed in South Ossetia, where it managed to maintain a cease-fire and shaky peace. ${ }^{383}$

In South Ossetia, unlike Abkhazia, the issue of population exchanges was not so important, since both sides accepted de facto the exchanges and some Georgians managed to go back to South Ossetia. The South Ossetian leadership argued that they would ask for the same status as was eventually agreed upon with Abkhazia, while the

\footnotetext{
${ }^{381}$ Julian Birch, “Ossetia: A Caucasian Bosnia in Microcosm," Central Asian Survey, 1995, vol. 14, no. 1, p. 49.

${ }^{382}$ Zurcher, 2005, pp. 106-107.

${ }^{383}$ Birch, 1995, p. 49.
} 
Georgian government proposed a different model of autonomy. ${ }^{384}$ In conclusion, it was the intensity of the conflict between the different Georgian political factions and ethnic groups and the failure to set up sound state structures and institutions that were the most serious internal threats to Georgia.

\section{External Threats}

The main potential external threat to Georgia comes from the north. As the Abkhazian and Ossetian conflicts became real challenges to Georgia, Russia took advantage of those conflicts and the division of the Georgian political elite and paramilitary groups against each other. In addition to those, Gamsakhurdia's nationalism and Shevardnadze's problematic relationship with Russia, where Shevardnadze was blamed for the demise of the Soviet Union, complicated the Georgian condition and its relations with Russia. Even though Shevardnadze's international reputation attracted much Western media attention to Georgia, the major western powers were not interested and active in the region. They considered Georgia as within the Russian sphere of influence.

The role of Russia in the Abkhazian conflict dissatisfied the Georgian leadership. The Georgian government accused the Russian peacekeeping forces of not fulfilling their mandate or securing the return of the displaced Georgians, loose border controls, and Russian unwillingness to complete its withdrawal, scheduled for 2001, from its military base in Gudauta in Abkhazia. The Georgian government has several times threatened to refuse to extend the Russian peacekeeping forces mandate, complaining that the presence

\footnotetext{
${ }^{384}$ Matveeva, 2002, p. 439.
} 
of the Russian peacekeeping forces is responsible both for the de facto independence of Abkhazia and the displacement of ethnic Georgians from Abkhazia. ${ }^{385}$

The two Russian wars in Chechnya have had a key effect on the level of Russian influence on Georgia. During the first Chechen war (1994-1996), the Russian military needed to guarantee Shevardnadze's support against the Chechen fighters and especially his permission to use Georgian territory for air strikes on Chechnya. In return for this, the Russian military were ready to close the Russian-Abkhazian borders and to set restrictions on the Abkhazians. However, in the Chechen interwar period (1997-1999) the Georgian-Chechen relations improved to a great extent while relations with Russia declined. The opening of the Russian border with Abkhazia in retaliation for the loose border controls over the Chechen sector with Georgia marked the beginning of the second Chechen war in $1999 .^{386}$

Thus, while support for Georgian independence in 1991 was nearly unquestioned among ethnic Georgians, the political leaders' failure to build legitimate and effective state structures and their failure to guarantee basic law and order as well as Russia's desire to control Georgia had a very significant impact on Georgian foreign policy. Following the Georgian defeat in Abkhazia and its acceptance of de facto independence for South Ossetia, Shevardnadze was forced to bandwagon with respect to the main external threat, i.e., Russia. Moreover, by the beginning of 1994, it became almost impossible to mobilize the Georgian population against new external and internal threats

\footnotetext{
${ }^{385}$ Cornell, 2001, pp. 351-353.

${ }^{386}$ Matveeva, 2002, p. 421.
} 
to national security. In this respect, Georgia represents a clear example of the importance of internal factors to national security and foreign policy. ${ }^{387}$

\section{c. Leadership}

\section{Zviad Gamsakhurdia (1991-1992)}

Gamsakhurdia's presidency can be characterized by volatility, political chaos, and international isolation. His presidency, based on populist nationalist themes of national unity, traditionalism and anti-elitism, fascinated a Georgian population that had become disillusioned with the Soviet-system. Under these circumstances, Gamsakhurdia turned into a national leader for ethnic Georgians in Georgia and captured power. Nevertheless, Gamsakhurdia's policies cannot be understood independent of the legacy of both the Georgian and Soviet political cultures. The Soviet style of political system created the circumstances necessary for Gamsakhurdia's populist nationalism.

Gamsakhurdia's nationalist policies were based on the glorification of the Georgian past, state paternalism and intolerance of ethnic minorities. ${ }^{388}$ Gamsakhurdia, like most Georgians, believed that independence, elections and a multiparty parliament were sufficient for democracy. Concepts such as the protection of minorities and their rights, competition between different contending political groups based on the rule of law, and limiting executive power guaranteed by the rule of law were poorly understood by dissidents of the Soviet Union. ${ }^{389}$

\footnotetext{
${ }^{387}$ Aves, 1995, p. 216; and Wheatley, 2005, p. 223.

${ }^{388}$ Vamil Volkan, Killing in the Name of Identity: A Study of Bloody Conflicts, (Charlottesville: Pitchstone Publishing, 2006), pp. 28-29.

${ }^{389}$ Elizabeth Fuller, "Gamsakhurdia's First 100 Days," RFE/RL Report on the USSR, 08 March 1991, vol. 3 , no. 7, pp. 10-13.
} 
Gamsakhurdia's emphasis on Georgian nationalism and national unity led him to a number of conclusions: ethnic minorities were dangerous, the state should be active and watchful, and that the media and the opposition were divisive and untrustworthy. Gamsakhurdia's rejection of conciliation with the opposition and his lack of understanding of institutional boundaries in the political arena led to an association of himself and his allies with the state. His populist style, with its emphasis on referenda, rallies, letter-writing campaigns and praise of the leader, created an extremely emotional environment. He called his opponents the 'enemies of the nation' and 'red intelligentsias'. Therefore, once in office, Gamsakhurdia proved to be both incompetent and incapable, restricting the civil liberties of his opponents, using his office to accumulate more power, and severing harmony and creating ethnic tensions among minorities in Georgia. ${ }^{390}$

By the summer of 1991, the national unity that Gamsakhurdia so desperately sought was disintegrating. The prominent political elite of Tbilisi were severely upset by Gamsakhurdia's attacks on their authority and his heavy-handed treatment of political institutions through personnel changes. Parliamentarians, including members of his own bloc, were alienated by Gamsakhurdia's manipulation of the executive process, endless revisions to the constitution, and frequent use of presidential decrees. ${ }^{391}$

Gamsakhurdia refused to criticize the leaders of the failed coup attempt against Gorbachev in 1991 even though the coup leaders favored putting a stop to the tendency toward independence among the union republics, including in Georgia. This caused

\footnotetext{
${ }^{390}$ Areshidze, 2007, pp. 20-23 and Wheatley, 2005, pp. 53-55.

391 Stephen Jones, "Georgia: The Trauma of Statehood," in New States, New Politics: Building the Post-

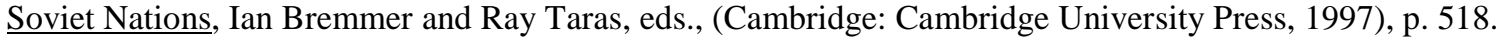


demonstrations and resignations from his government, including the Prime Minister Tengiz Sigua and the Foreign Minister Georgy Khoshtaria. When Gamsakhurdia decided to place the Georgian National Guard under the control of the Georgian Ministry of Interior, the majority of the National Guard, the only effective military force in Georgia apart from Soviet forces, followed its commander, Tengiz Kitovani, into opposition. Moreover, many of his opponents, and even some of his former close allies, believed that he had become emotionally and politically unstable. ${ }^{392}$

Gamsakhurdia turned to blame the old nomenklatura as well as opposition leaders. Shevardnadze, in Moscow, was a major target of Gamsakhurdia's anger. As late as the spring of 1991, Gamsakhurdia vowed that he would never permit the return of his former rival. From August 1991 to the end of the year, when Gamsakhurdia was ousted by a coup led by the National Guard and paramilitary groups of the extra-parliamentary opposition, there were clashes between Gamsakhurdia's loyalists and the opposition forces in streets of Tbilisi. Several weeks after the demise of the Soviet Union in December 1991, Gamsakhurdia was forced to seek safety in the basement of the parliament building. ${ }^{393}$

Thus, Gamsakhurdia's decision to put all the power ministries under direct presidential control, his expulsion of the entire Communist Party bloc from parliament, and his attempt to rally support for his defense confirmed the belief that he was an ineffective leader. At the end of 1991, Gamsakhurdia escaped from Tbilisi for the border

\footnotetext{
${ }^{392}$ Areshidze, 2007, pp. 12-13 and Elizabeth Fuller, “Eduard Shevardnadze's Via Dolorosa," RFE/RL Research Report, 29 October 1993, vol.2, no. 43, p. 17.

${ }^{393}$ Jaba Devdariani, “Georgia: Rise and Fall of Façade Democracy,” Demokratizatsiya, Winter 2003, vol. 12 , no. 1, pp. 87-91.
} 
with Azerbaijan, then sought asylum in Chechnya before crossing the border into western Georgia. After being surrounded by Shevardnadze's forces in western Georgia, Gamsakhurdia apparently committed suicide on December 31, $1993 .{ }^{394}$

To summarize, Gamsakhurdia became the leader of the opposition in 1989, in the wake of the Soviet massacre, and was elected president of Georgia in April 1991, a few days after the second anniversary of the Tbilisi massacre. He received more than 85 percent of the vote, reflecting his prominent role in the nationalist movement in Georgia. He was ousted less than a year later, in January 1992. He introduced authoritarian rule and strong nationalist policies, aggravated separatist sentiments in Abkhazia, Ajaria, and South Ossetia and made the Georgians themselves impatient with his intolerance and violence.

\section{Eduard Shevardnadze (1992-2003)}

Shevardnadze had spent his entire life and career in Georgia until summoned to Moscow in 1985. He became the General Secretary of the Georgian Communist Party in 1972 after an early career in the Interior Ministry. He had conducted several "anticorruption campaigns," until Gorbachev appointed him the Soviet Foreign Minister. Seven years later, he returned with the aim of reconciling rival political factions, ending separatist struggles and the country's international isolation. ${ }^{395}$

As the Communist Party leader in Georgia in the 1970s, Shevardnadze worked in distinctive and unconventional ways, pursuing the path that would best serve his interests and advance his goals. He linked himself with power patrons in Moscow and operated

\footnotetext{
${ }^{394}$ Wheatley, 2005, p. 60 and Areshidze, 2007, p. 31.

${ }^{395}$ Elizabeth Fuller, "Eduard Shevardnadze's Via Dolorasa,” REF/RL Report, 29 October 1993, vol. 2, no. 43, p. 17.
} 
skillfully within the Soviet system. At the same time, he pursued policies that, in the Soviet context, were liberal and enlightened. In addition to that, Shevardnadze's praise of the general secretary of the Soviet Communist Party, Leonid Brezhnev, was exceptional during his rise through the Soviet hierarchy. He was the first to pay tribute to Brezhnev at the 25th Party Congress in 1976, at the peak of Brezhnev's cult of personality, referring to Brezhnev as vozhd (leader), a term previously reserved for Stalin. Shevardnadze was exceeded in his praise only by Azerbaijan's leader Haydar Aliyev. ${ }^{396}$

In January 1992, the Military Council came to power, led by the troika of Tengiz Kitovani, the Commander of the National Guards; Tengiz Sigua, Gamsakhurdia's former prime minister; and Jaba Ioseliani, leader of the powerful paramilitary organization Mkhedrioni. The Military Council proved incompetent in restoring order or in ending Georgia's international isolation. Two months after the ouster of Gamsakhurdia the Military Council invited Shevardnadze to lead the country again. Shevardnadze returned to Tbilisi in March $1992 .^{397}$

Shevardnadze took over a failed state which no longer had a monopoly on legitimate violence over the country. For this reason, Georgia was considered a failed state. $^{398}$ There were three conflicts, two with the South Ossetian and Abkhazian

\footnotetext{
${ }^{396}$ See Carolyn M. Ekedahl and Melvin A. Goodman, 1997, p. 13. The 25th Congress of the Communist Party in Moscow Shevardnadze told the delegates that "for Georgians, the sun rises not in the east, but in the north, in Russia." See, Suny, 1994, p. 310.

${ }^{397}$ Elizabeth Fuller, 29 October 1993, p. 17.

${ }^{398}$ See, Robert I. Rotberg, "The Failure and Collapse of Nation-States: Breakdown, Prevention, and Repair," in When States Fail: Causes and Consequences, Robert I Rotberg, eds., (Princeton: Princeton University Press, 2004), pp. 1-10. Rotberg define failed state as "tense, deeply conflicted, dangerous, and contested bitterly by warring factions," p. 5. In some literatures, Georgia is called as a fragmented state. A fragmented state "provides basic services to their citizenries, but have lost-or are losing-coercive control over significant portions of their territory," Erin K. Jenne, "Sri Lanka: A Fragmented State," in State Failure and State Weakness in a Time of Terror, Robert I. Rotberg, ed., (Washington, D.C.: Brookings Institution Press, 2003,), p. 219 and p. 222.
} 
secessionists, and the political fighting with the Gamsakhurdia's supporters in Mingrelia, in western Georgia. Furthermore, the southwestern autonomous republic of Ajaria under Aslan Abashidze was out of Tbilisi's control. The Armenian and Azerbaijani-populated regions on the republic's southern borders had established ethno-political hierarchies that in fact ran themselves. There were no security forces responsible for the rule of law and order. Rather there were a number of competing paramilitary groups, and the structures of government had ceased to operate.

Among the challenges that Shevardnadze faced, the most vital were an end to the wars in South Ossetia and Abkhazia, accommodation of Georgia's ethnic minorities in these regions, prevailing against violent Zviadist opposition groups in western Georgia, and re-establishing governmental control over the paramilitaries in the country. To deal with these challenges, he sought and received assistance from the Russian President Boris Yeltsin, but the price was high. He accepted a Russian-brokered ceasefire for the South Ossetian and Abkhazian conflicts; membership of Georgia to the CIS; and the establishment of four Russian military bases on Georgian territory.

However, Shevardnadze's period in office brought varied results in Georgian internal and external politics and many of the problems remained unresolved in the early 1990s. He was shadowed by powerful paramilitaries reluctant to abandon their power, Russian military intervention in Abkhazia and to a lesser extent in South Ossetia as well as devastation of the country's economic and political infrastructure in the early 1990s. Despite these obstacles, Shevardnadze's pragmatism and his willingness to compromise brought the conflict in South Ossetia to an end within three months of his arrival. Within seven months in October 1992 he had established a newly elected parliament and 
temporary power structure, with himself popularly elected as both Chairman of Parliament and Head of State. In June 1992 Shevardnadze survived a coup attempt by Gamsakhurdia's supporters in the center of Tbilisi, but far more threatening was the war in western Georgia where Gamsakhurdia had widespread support among the local Mingrelian population. The war lasted until the autumn of 1993, when Gamsakhurdia's forces were defeated by Georgian forces with support by the Russians.

In the second half of the 1990s, Shevardnadze was able to bring about a relative degree of stability and peace to Georgia by increasing the authority of state, disbanding the paramilitary groups, establishing an environment in which basic economic development could start, and creating a legal framework for constitutional change to happen. ${ }^{399}$ Externally, Shevardnadze tried to decrease Georgian dependency on Russia and build a strategic relationship with major western powers, especially with the United States, and regional powers, like Turkey. He also sought to benefit from U.S.-Russian competition on the Caspian oil reserves and worked to pass the main pipeline through Georgia so that Georgia could benefit both economically and politically from the competition.

In conclusion, Shevardnadze's foreign policy was filled with ups and downs and contradictions, just like his overall career. He demonstrated his ability to deal with the political winds and do whatever was crucial to suit his goals and achieve his political objectives, such as collaborating with the paramilitary leaders in the early 1990s. Shevardnadze also displayed considerable courage and pragmatism, such as going to Sukhumi when it was under siege. Moreover, he had the courage to make and implement difficult decisions, e. g., joining the CIS when most of the Georgian political elites as

\footnotetext{
${ }^{399}$ Areshidze, 2007, p. 33.
} 
well the Georgian public considered Russia as the main threat. While much of Shevardnadze's subsequent justification for his behavior was self-serving, unlike most Georgian politicians, Shevardnadze understood the need for concessions, for instance, accepting the Russian military presence in Abkhazia and South Ossetia. He made clear that he would not tolerate the exploitation of other ethnic groups in the country by pursuing a more tolerant Georgian nationalism. Thus, he was careful to balance both internal players and external major powers.

\section{d. External Influence}

\section{Russia}

The Russian political and military elites have always considered the Caucasus to be part of their sphere of influence, and Boris Yeltsin was no exception. For instance, the last Soviet defense minister and Yeltsin's first commander-in-chief, Yevgeni Shaposhnikov, compared Russia's presence in Georgia to the first imperial transition after the Bolshevik Revolution as well as the Russian sphere of influence in the Caucasus to that of the United States in Central America. ${ }^{400}$ Yeltsin, on the one hand, wanted to end the fighting and stop the Abkhazian drive for independence, fearing a model for such secessionist-minded regions of the Russian Federation as Chechnya, Ingushetia, and Tatarstan. He also realized that a wider confrontation in the Caucasus risked the problem of spillover into Russia or intervention from the United States, Turkey or Iran into the "Near Abroad." On the other hand, Yeltsin, his Prime Minister Viktor Chernomyrdin and

\footnotetext{
${ }^{400}$ Ekedahl and Goodman, 1997, p. 274.
} 
most of his ministers considered Abkhazia a part of the Russian Federation rather than an integral part of Georgia. ${ }^{401}$

The Russian government had sought to maintain control of Abkhazia in particular and thereby in Georgia more generally. Russia considers Georgia a Russian sphere of vital interest as a safeguard against instability in the North and South Caucasus. On the other hand Abkhazia provides wider access for Russia to the Black Sea coast. Thus, there was significant empathy among Russian political and military elites for supporting the Abkhazian separation from Georgia. Therefore, Yeltsin made no effort to stop members of the Russian military forces from helping the Abkhazian separatists. The Russia army officers in Abkhazia and Georgia, all of them anti-Shevardnadze and some of them beyond Yeltsin's control, took part in the Georgian-Abkhazian conflict. The use of Russian tanks and aircraft led to the crushing of Georgian forces in Abkhazia in August 1993. ${ }^{402}$ The Abkhazian forces took control of the entire area from the Russian border to Sukhumi.

Yeltsin and his first Foreign Minister, Andrei Kozyrev, wanted the international community, particularly the United Nations, to recognize Russia's special role as the sole peacekeeper on the territory of former Soviet Union. The Russian ruling elite argued that their military forces were carrying out a public service, ensuring stability and mediating between conflicting sides to manage and find solutions for ethnic and civil conflicts in the region. However, peacekeeping was a completely new mission for Russia. The Russian

\footnotetext{
${ }^{401}$ Ekedahl and Goodman, 1997, p. 266.

${ }^{402}$ Ekedahl and Goodman, 1997, p. 266 and Lynch, 2000, p. 137, The Russian Defense Minister, Pavel Grachev, during a visit to Abkhazia in early 1993, said that "I will only say that this is a strategically important area for the Russian army. We have certain strategic interests here and must take every measure to ensure that out troops remain: otherwise we will lose the Black Sea." See Mark Smith, Pax Russica: Russia's Monroe Doctrine, (London: Royal United Services Institute, 1993), p. 54.
} 
military leaders already considered the missions as military operations because they lacked a peacekeeping doctrine and provided no training to their troops for peacekeeping missions. ${ }^{403}$ Moreover, Georgian political elites and public were suspicious about the Russian peacekeeping forces and blamed them for supporting and supplying separatist groups in Abkhazia and South Ossetia. In addition to that they remembered how the Soviet military had used force in Georgia in 1989 and in Azerbaijan in 1990.

The United Nations had authorized the deployment of the Russian peacekeeping forces and United Nations observers in Abkhazia marking the first United Nations peacekeeping presence in the former Soviet Union. Besides, the United Nations indirectly endorsed Georgia as within the Russian sphere of influence by accepting the sole deployment of the Russian peacekeeping forces. Shevardnadze and Ardzinba accepted a Russian peace plan for Abkhazia that included Russian "peacekeeping forces" to guard the de facto border. Thus, Russia forced the Shevardnadze government to accept the Russian peacekeeping forces. Shevardnadze first received the Russian support against the Zviadist paramilitary forces in Mingrelia and then acquiesced in Russian peacekeeping forces in Abkhazia. Shevardnadze realized that Georgia was a major loser and had no alternative but bandwagoning with Russia. ${ }^{404}$

Yeltsin visited Tbilisi on February 3, 1994, to conclude a bilateral treaty of friendship and cooperation with Georgia.Yeltsin pressed Shevardnadze to agree on legalization of the status of the Russian bases in Georgia and Abkhazia. He told a news

\footnotetext{
${ }^{403}$ Dov Lynch, Russian Peacekeeping Strategies in the CIS: The Cases of Moldova, Georgia and Tajikistan, (New York: St. Martin's Press, 2000), pp. 24-26. See also, Lena Johnson and Clive Archer, eds., Peacekeeping and the Role of Russia in Eurasia, (Boulder: Westview Press, 1996).

${ }^{404}$ After the Georgian forces defeated in Abkhazia, Shevardnadze said "we have to co-operate with Russia...otherwise Georgia will collapse and disintegrate." See, Lynch, 2000, p. 139.
} 
conference during his one-day visit to Tbilisi: Russia respects Georgia's territorial integrity while fully honoring the interest of Abkhazia and South Ossetia. There was great opposition among political and military circles in Moscow to closer ties to Georgia. Yeltsin acknowledged their concern, stating that the treaty would be submitted for ratification until the legal and political status of Abkhazia and South Ossetia was settled under a new Georgian constitution. ${ }^{405}$

Thus, Russia remained the main player in the Caucasus, and became increasingly active particularly in Georgia, where Moscow used its military and economic assistance to gain leverage in Tbilisi after Yeltsin's trip. The price of Russian involvement was the potential challenge to Georgian sovereignty. Therefore, Russia had taken advantage of the chaotic circumstances and forced Shevardnadze to accept Georgian membership in the CIS and the existence of Russia's military bases in Georgia. It is clear that Russia weakened Shevardnadze and pushed him to accept the Russian military presence and influence in the country. Shevardnadze realized that his government would remain dependent on Russian assistance. He also realized that stability in Georgia related in part on the direction of events in Russia and involvement of other major external powers in the region.

The Russian influence on Georgia declined in the winter of 1994-95, when the first Chechen war started. In other words, political instability in the North Caucasus decreased Russian influence on Georgia. With the Caucasus ethnic groups spread across so many borders, no conflict in the region can be considered the simply internal affair of any one state. Furthermore, in the summer of 1995, Shevardnadze's successful efforts to gain international support for the rebuilding of an energy pipeline from Azerbaijan to

405 Thomas De Waal, “Georgia Accord Attacked,” The Moscow Times, 5 February 1994. 
Georgia's Black Sea coast particularly angered Moscow. Russian leaders were determined that oil should flow north through Russia. So both the Chechen war and oil pipeline issues provided Shevardnadze for maneuver space when dealing with Russia. Shevardnadze concentrated on attracting western interest to the region and make them balance Russian influence there.

\section{The United States}

At the collapse of the Soviet Union, the U.S. policy toward the post-Soviet states was profoundly dictated by concern for the future of Russia, and in particular concern for the control over the Soviet nuclear arsenal. Thus, the United States governments, especially the Clinton administration, developed a 'Russia-first' policy because they were concerned over the stability of the Yeltsin's regime and promoting Russia's liberaldemocratic development. For that reason, in the first half of the 1990s American interests were weak and the United States did not have a clearly defined policy on the Caucasus region. Basically, the American administrations considered the Caucasus region as a sphere of influence of Russia. ${ }^{406}$

Under Gamsakhurdia's regime, the United States did not have any significant relations with Georgia. But, after Shevardnadze came to power, the relations between the United States and Georgia improved. The reason is that Shevardnadze was a well-known and well-respected figure in the western world, especially in the United States and Germany because of the role which he played as the Foreign Minister of Soviet Union between 1985 and 1990. In other words, Shevardnadze was recalled as a pro-Western Soviet foreign minister who had played a crucial role for unification of Germany and in

\footnotetext{
${ }^{406}$ S. Frederick Starr, "Power Failure: American Policy in the Caspian," The National Interest, Spring 1997, p. 25 and Cornell, 2001, pp. 366-367.
} 
ending the Cold War. ${ }^{407}$ However, although Shevardnadze was considered as a friend of the West, the American commitment to Georgia was minimal. The United States supported international organizations' efforts to solve conflicts in Georgia and also supported having Russian peacekeeping forces in the country, even though many in the United States saw the Russian peacekeeping forces in Georgia as a restoration of Russian imperial rule. Russian troops might have ended the fighting between different ethnic groups but Americans believed Russian troops would stay in Georgia. Shevardnadze also believed so. Initially he opposed exclusively Russian peacekeeping forces in Georgia, which implied international recognition of a special Russian role in the 'near abroad'. However, the United States and other permanent members of the UN Security Council supplied no other peacekeeping forces than observers. Therefore, Shevardnadze had to comply with a dominant Russian role as a last resort because he lacked military force of his own and the United States refused to take the lead in arranging United Nations peacekeeping forces. ${ }^{408}$

One of the reasons is that the Clinton administration did not want to challenge Russia in its periphery. When he was on his first visit to Moscow in 1993, Clinton essentially invited a greater Russian role in the Caucasus and Central Asia, comparing Moscow's involvement on its border with the United States involvement "in the last few years in Panama and Grenada near our area." He credited the Russian military with being "instrumental in stabilizing" the political situation in the region. Therefore, Russia received a free hand from the United Nations for its peacekeeping forces in Georgia, and

\footnotetext{
${ }^{407}$ Cornell, 2001, p. 368.

${ }^{408}$ Charles King, “A Rose Among Thorns: Georgia Makes Good,” Foreign Affairs, March/April 2004, vol.83, no. 2, p. 17; Ekedahl and Goodman, 1997, p. 274, and Cornell, 2001, p. 371.
} 
the United States had received in return UN endorsement for its intervention in Haiti. ${ }^{409}$ Thus, Clinton's comparison of Russia's intervention in Georgia to the U.S. action in Grenada and Panama gave the Russians freedom to intervene in the Caucasus. As a result, Moscow, assigning the Caucasus to its sphere of influence, compared its intervention in Georgia to the United States role in Haiti.

U.S. policy on the Caucasus started to change in the middle of the 1990s, reflecting a growing U.S. awareness of the importance of Georgia in the Caucasus as well as in the Caspian region. For these reasons, the Clinton administration promised Shevardnadze during Shevardnadze's visit to Washington, D.C. in March 1994 that the United States would lobby for International Monetary Fund assistance to Georgia and offer financial support for a U. N. presence in Georgia. As a result, the IMF extended an assistance grant in November 1994, along with an offer to cancel some of Georgia's $\$ 850$ million debt. Most importantly, Shevardnadze's visit opened a way to involve Georgia in the Caspian project. Georgia also joined the NATO Partnership for Peace program in 1994. ${ }^{410}$

Georgia is important for the United States because Georgian territory presents the only reliable way in which Caspian hydrocarbons can be transferred to the world market. For the success of the pipeline project through Georgia the Clinton administration in the second half of 1990s devoted a substantial amount of financial and political resources to allow the Shevardnadze government to develop a stable and strong state structure.

\footnotetext{
409 Zbigniew Brzezinski, “The Premature Partnership,” Foreign Affairs, March/April 1994, vol. 73, no. 2, p. 70 and Ekedahl and Goodman, 1997, p. 277. See also, Farhan Haq, "Georgia-Haiti: Did the United Nations Host a Great Power Trade?” IPS- Inter Press Service, 1 July 1994; and Georgia Gedda, "Russia Backs U.S. Haiti Policy But for a Price," The Associated Press, 2 August 1994.

${ }^{410}$ Alexander Rondeli, "The Choice of Independent Georgia," in The Security of the Caspian Sea Region, Gennady Chufrin, ed., (Oxford: Oxford University Press, 2001), p. 198.
} 
Georgia also received aid from the United States and NATO for training and equipment for its border guard and military. ${ }^{411}$

\section{e. Conclusion}

Georgia's condition following independence was typical of a post-colonial society that achieved independence more through collapse of empire than by a long-term effort of a national struggle. Soviet/Russian armies were stationed in various parts of the country, and the country as a whole was economically and politically dependent on the imperial center, Moscow. Conflicts over state borders and ethnic conflicts were turning into full-fledged warfare, while competition between the Communist nomenklatura and nationalist elites as well as amongst them became violent. Therefore, political fighting and ethnic divisions negatively influenced the establishment of stable and coherent state institutions and had a severe impact on the strength of the Georgian state.

Moreover, lack of political stability and high nationalist tendencies among Georgian nationalist elites provided a suitable atmosphere for ethnic minorities (Abkhazians and South Ossetians) to declare self-determination. Violent political struggle among political elites to control government signified that the Georgian government was incapable of dealing with ethnic rebellions. Thus, the weakness of Georgian state structures, ethnic wars and conflicts of different political and paramilitary groups posed the main internal threat for the Georgian government and state's sovereignty.

Under Gamsakhurdia, a staunch nationalist leader, the political and economic condition in Georgia worsened. Gamsakhurdia, as an inexperienced idealist, turned

\footnotetext{
${ }^{411}$ Mark Eaton, "Major Trends in Military Expenditure and Arms Acquisitions by the States of the Caspian Region," in The Security of the Caspian Sea Region, Gennady Chufrin, ed., (Oxford: Oxford University Press, 2001), p. 95.
} 
Georgia into a failing state which could not provide security and the basic services of statehood. In addition, his version of Georgian nationalism aggravated clashes between the Georgian government and ethnic groups within the country. He also alienated not only the international community but also some of his own nationalist colleagues with his uncompromising policy. As a nationalist leader, like Elchibey, he considered Russia to be the main threat and saw it as an imperial power that wanted to continue its dominance over Georgia. He refused to cooperate with any Russian government on any subject.

After Shevardnadze came to power, he started to change the previous Georgian government's policies. First, he tried to fully control state institutions and the state itself. He regarded ethnic, opposition and paramilitary groups as the main threat to his government. Second, the weakness of Georgian state institutions and violent challenges of opposition groups to Shevardnadze's leadership, and the collapse of Georgia's ragtag army in Abkhazia, led Shevardnadze to ask Russia for assistance to rescue his government. Shevardnadze was thus compelled to balance his main internal threat with the secondary threat of Russia. Russia took advantages of divisions within the Georgian political elites and ethnic conflicts in the country and imposed its own preconditions. Shevardnadze thus signed military agreements with Russia, joined the CIS and accepted Russian military bases on Georgian soil. Had he refused, he might well have been overthrown by internal forces. So, he first dealt with internal threats and basically bandwagoned with Russia to cope with internal opposition.

Shevardnadze established full control over Georgia by the middle of the 1990s. After he consolidated his power, eliminated all competitors as well as increased external involvement in the middle of 1990s, he developed foreign policy of balancing Russian 
influence with the involvement of other major powers in the region. He successfully lobbied to pass a pipeline through Georgia so Georgia could receive attention from those major powers that invested to the pipeline. Therefore, Shevardnadze, like Aliyev, approached the secondary threat for defeating the main internal threat. Again, like Aliyev, when he secured his position, defeated internal opposition, and elaborated external assistance, he shifted his policy to balance external Russian threats in his country.

Shevardnadze's pragmatism, his willingness to compromise and his opportunism shaped Georgian foreign policy during the 1990s. He demonstrated his ability to deal with the political winds and do whatever was crucial to suit his own personal goal and national interest of his country, and achieve his political objectives. He was careful to balance both internal players and external major powers during the 1990s. Thus, the failure to build effective state structures and coherent relations with ethnic minorities had a significant impact on Georgian foreign policy and Georgian-Russian relations.

\section{Conclusion}

Overall, the internal factors influencing the foreign policy-behavior of the Caucasus states were political instability, weak state institutions, power struggles among political elites, and ethnic conflicts within these states. As a result of the mobilization of ethno-nationalism and lack of strong political institutions, internal threats became the primary threats for these states, especially for Azerbaijan and Georgia. These internal factors shaped directly or indirectly both the orientation and implications of foreign policies of the Caucasus states. Directly, power struggles among political elites and ethnic conflicts within these states opened the way for external influence on their internal 
and external politics. For example, Russian forces involved or played active roles in coups in both Georgia and Azerbaijan as well as wars in Abkhazia and Karabagh in the early 1990s. Indirectly, the weakness of state institutions and political instabilities made the countries vulnerable and sensitive to any threats (either internal or external, or both) to their foreign policy direction. For example, as weak states, the Caucasus states could not deal with potential external threats and even some of the internal threats themselves; therefore, they needed allies in order to secure their newly acquired sovereignty. They pushed to accept either bandwagoning with the potential external threat or to look for major power(s) balancing against the potential threats, in the way that Armenia balanced a potential Turkish threat with Russia.

Another weakness of the Caucasus states was making the government's rules effective across the country and among ethnic groups, such as Karabagh in Azerbaijan and South Ossetia and Abkhazia in Georgia. The reason is that as weak states, loyalties to clans, tribes, and regional-affinity are very strong in the Caucasus states. Therefore, the threat of separatist tendencies in these states often became the main threat to governments in the region.

Internal threats, especially ethnic ones in the Caucasus, were related to the collapse of the Soviet Union and provided an opportunity for the imperial center, Russia to manipulate these conflicts to gain influence. Therefore, national security threats in the Caucasus were often based solely on domestic factors. Threats to these states were also the result of interactions between external and internal factors. The external threat was the Russian fear of losing its influence in the region, because the Caucasus states remain at the geographic point of competition between major powers. Because of the weakness 
of the Caucasus states, they had clearly limited options in dealing with Russia. When they confronted Russia, the internal strength of the Caucasus states was not sufficient to withstand Russian pressures. Under such circumstances, the Caucasus states tried to establish an alignment with another major power for assistance. Thus, external threats and factors are also critical to any analysis of the post-Soviet Caucasus foreign policies.

Moreover, because of weaknesses and authoritarian tendencies, the Caucasus states' foreign policy decisions ultimately were made by the leaders of these states. Therefore, the survival of these states and their leaders largely depended upon leaders' orientations and abilities to be in control and command their state as well as their perceptions and interests in implementing certain foreign policy options. Leaders' perceptions of politics and the place of their countries in the international system induced their foreign policy choices. For example, Russian relations with Georgia and Azerbaijan were affected negatively by nationalist leaders, such as Gamsakhurdia in Georgia and Elchibey in Azerbaijan, because of their adamant rejection of the old imperial order of Russia in the Caucasus.

Changes of leadership had an important impact on the foreign policy orientation of the Caucasus states. Different personal characters and interests of leaders respond differently to similar conflicts. For instance, self-oriented leaders, on the one hand, seek to respond to domestic threats in the course of power accumulation and balancing, as exemplified by Aliyev's and Shevardnadze's policies in the early 1990s. Nationalistoriented leaders, on the other hand, may construct an isolationist policy, which allows them to isolate their countries from external intervention in their domestic problems, such as in Georgia under the leadership of Gamsakhurdia. Therefore, factional political 
infighting and frequent changes of leaderships hindered the attempt to establish coherent foreign policy orientations in the Caucasus in the early years of the 1990s.

Consequently, internal factors, such as the relative weakness of these states; levels and types of threats, as well as the level of external involvement created a political environment in which leaders of the Caucasus states acted and implemented their own beliefs and interests with respect to their countries' foreign policies.

In sum, the Caucasus states' foreign policies became mainly a response to the weakness of their own states and domestic threats. Domestic conflicts created vital threats to leaderships and prevented these countries from developing strong state institutions. Domestic threats turned out to be far more important than external ones for these states, particularly for Azerbaijan and Georgia in the early 1990s. These states also attempted to mobilize key external players in ways favorable to the maintenance of the regime in power. In other words, for these states, especially in the early 1990s, foreign policy was domestic policy pursued by other means. 


\section{Chapter IV}

\section{Introduction:}

The first part of this chapter discusses the foreign policy-making process itself. The chapter assesses the characteristics of foreign policy-making in Armenia, Azerbaijan and Georgia. How did leaders and political elites of Armenia, Azerbaijan and Georgia contribute to shaping policy options through their perception of international politics in general and their understanding of the Russian influence on their countries in particular? To what extent were leaders of these states able to lead their states away from Russian domination, despite their dependence on Russia as the ex-imperial center? What kinds of roles do other external powers play?

The second part of this chapter provides an analysis of Armenian, Azerbaijani and Georgian foreign policy behaviors. In particular, this chapter examines the relations between Armenia, Azerbaijan and Georgia with Russia. Examining foreign policy behaviors of Armenia, Azerbaijan and Georgia will provide a basis from which to judge whether it has adopted a balancing, bandwagoning, or omnibalancing foreign policy stance. The chapter also concentrates on the reasons for differences between Armenian foreign policy, on the one hand, and Azerbaijani and Georgian foreign policies, on the other.

The body of data available for relations among the Caucasus states and Russia may be organized into three broad categories: measures of direct interaction, measure of attributed influence, and case studies. First, the measures of direct interaction bring into play the entire range of quantitative data, such as trade, aid and exchanges of missions as well as diplomatic relations. Though readily available and plentiful, these data turn out to 
have a low value to understand the foreign policy of these countries: in particular, they provide us with little information on an influence relationship between weak states and their stronger neighbors. A second category of data measures the leaders' perceptions and attitudes. These data include joint communiqués and evaluations of editorials and articles in key newspapers and journals, official speeches and statements. Third, case studies offer an opportunity to outline the issues which have significant influence on the foreign policy of these countries. In this dissertation, heavy reliance will be placed on the last two categories.

The foreign policy of a state can define a series of external actions pursued to achieve certain defined objectives or goals. Some of these goals may have to do with the internal politics of the state. In addition, a state's foreign policy choices are shaped not only by internal factors but also by the interplay between these and external factors such as the dominance of a more powerful state in the region. In other words, foreign policy behavior may be explained as the product of the interaction between the state's domestic needs and the international or regional state system in which it operates.

Moreover, foreign policy is not an isolated phenomenon in respect of the state's other functions. It is based on the beliefs of leaders and a part of the political system which the state has, and it can be explained within the context of other state activities such as the objectives leaders have chosen, the economic situation, political conditions, geopolitical situation, and role of external actors. Therefore, the notion of states as cohesive units of international system pursuing agreed 'national interests' can be misleading in the Caucasus. In the region states have been fragmented and the statebuilding process is incomplete. In consequence, the complexity of state structures, the 
number of variables and their interaction create complex conditions in the Caucasus that test the premises of realist theories of foreign policy and international relations. ${ }^{412}$

This complex of domestic, regional and geopolitical conditions, as well as the conflict, competition, and cooperation between states, has been going on for almost two decades now in the Caucasus. The greater part of the competition occurs behind the scenes, while the disagreements between the major powers who are active in the region run so deep that a decisive role in defining the winner can be played by weaker local states. ${ }^{413}$ Therefore, analyzing state building, domestic politics and leaders' worldviews is especially relevant in analyzing foreign policies of the Caucasus region. One of the reasons is that sovereign states emerged in the Caucasus due to the collapse of the Soviet system rather than as the result of strong national movements seeking self-determination. Besides, the Caucasus states emerged on the scene as late developers. For all these reasons, the governments in the Caucasus lack strong state structures, foreign policymaking processes are therefore linked closely with the domestic politics of these states. ${ }^{414}$

Therefore, the most useful way to engage in foreign policy analysis in this context is to introduce the levels of analysis, which refer to the general areas from which certain foreign policy behaviors are generated within a state, and at which these behaviors occur between states. In other words, foreign policy-behavior occurs at the intrastate and interstate levels. Moreover, after a state decides to respond to a set of factors and

\footnotetext{
412 Juliet Kaarbo, et al., "The Analysis of Foreign Policy in Comparative Perspective," in Foreign Policy in Comparative Perspective: Domestic and International Influences on State Behavior, Ryan K. Beasley, et al., eds., (Washington, D.C.: CQ Press, 2003), p. 3 and Hinnebush, 2003, pp. 121-122.

${ }^{413}$ Georgiy Bovt, "In Politics, a Draw Often Means Victory,” Kommersant-Daily, 10 October 1995, p.1 and p. 4 in FBIS-SOV-95-197, 12 October 1995, pp.18-20.

${ }^{414}$ Scott A. Jones, "Introduction," in Crossroads and Conflict: Security and Foreign Policy in the Caucasus and Central Asia, Gary K. Brertsch, et al., eds., (New York: Routledge, 2000), p. 2.
} 
situations, its leadership is set in motion. This occurs when a state is initiating a foreign policy action as well as when it is reacting to the foreign policies of another state. This suggests the need to investigate actors' role in initiating foreign policy and in responding to those of the other states. ${ }^{415}$ Thus, to explain a state's foreign policy action, one needs to analyze three different levels: individual, intrastate, and interstate levels. In this way, a close study of international domestic developments, internal and external interactions among actors, and political issue-areas provides the student of the foreign policy of the Caucasus states with an understanding of the interaction between domestic and external factors shaping their foreign policy processes and actions in general as well as their relations with Russia in particular.

Moreover, the comprehensive investigation of their foreign policy at both domestic and external levels allows for developing a model to explain their foreign policy-behavior. This model is supported by three features; domestic politics, types of leadership and level of external relations of these countries. Thus, the first assumption is that to understand the Caucasus states' foreign policies we must cross and integrate several levels of analyses; the international relations of the region thus cannot easily be categorized as a systemic, sub-systemic, state-level or individual-level phenomenon. The second assumption is that capturing relations between leadership and state structure is necessary in order to answer to the question of why weak states have different kinds of foreign policies than those of strong states.

One of the main arguments of this chapter is that individual leaders' decisions in the newly independent states in the Caucasus played a crucial role in reshaping Caucasus

\footnotetext{
415 Jonathan Wilkenfeld, Gerald W. Hoople, Paul J. Rossa, and Stephen J. Andriole, Foreign Policy Behavior: The Interstate Behavior Analysis Model, (Beverly Hills: Sage Publications, 1980), p. 21.
} 
security and economic spaces. Therefore, the specific objective of the chapter is to follow how each leader of the Caucasus countries led their states and how and under what conditions they shaped their country's foreign policies. The primary interest is to explore the interplay of domestic and foreign policies and to show how the leaders managed to serve their own self and national interests in the foreign policy sphere. The reason is that "leaders not only interpret the situation which they find themselves in but often manipulate it, framing elements of the domestic and international environments to their audiences, drawing attention, involving new actors, instigating issue linkage." ${ }^{416}$

\section{The Caucasus: General}

The Caucasus region occupies a particularly sensitive strategic position, close to the Black Sea, the Caspian Sea, the Persian Gulf and the Russian Federation. Moreover, it forms a bridge between Turkey and Central Asia, as well as between Russia and Turkey. Thus, the region attracts the intense interest of outside actors, such as the United States, Russia, Turkey, Iran and the European Union. The area's complex multiethnic structure, the legacy of the imperial power of Russia (Tsarist and Communist) and the Russian Federation's "Near Abroad" policy, weak structures of new independent states (especially Azerbaijan and Georgia), and global and regional actors' desires to become involved in regional politics creates a distinctive pattern of regional security providing both opportunities and challenges for the Caucasus states. In other words, even though the Caucasus region has experienced a subordinate role in world politics, the competitive nature of the international and regional systems has nonetheless offered opportunities for

\footnotetext{
${ }^{416}$ Andrea K. Grove, Political Leadership in Foreign Policy: Manipulating Support Across Borders, (New York: Palgrave Macmillan, 2007), p. 2.
} 
the Caucasus states to overcome such subordination and to exploit competition among the major powers.

As part of the Russian Tsarist Empire and Soviet Union during the last two centuries, the Caucasus ethno-national communities were dependent on an external imperial power. The general condition of the states in the region has not changed fundamentally; therefore, economic and military weaknesses of the Caucasus states are the rule rather than the exception. Thus, the abilities of the Caucasus states to cope with the security complex of their environment depend on both the extent of their internal strength as well as external political and military assistance. Because they became independent only a short time ago, this depends on their level of state building. Therefore, leaders must command legitimacy and control state institutions while at the same time sustaining some minimum level of public supports for their foreign policy choices to establish internal cohesion.

It is thus clear that the leaderships of the three states that emerged in the Caucasus have faced enormous difficulties in reaching their foreign policy goals since independence. All these countries found themselves in a weak condition to begin establishing foreign relations with other states based on their national interests and without exception their security deteriorated sharply over the early years of the 1990s. These countries had to face their weakness in the international system and accept extensive limitations on their sovereignty. Therefore, foreign policy decisions concerning the Caucasus states stemmed from the structural character of the states' weaknesses in relation to their difficult geopolitical situation. ${ }^{417}$ In other words, in terms of their past experience, i.e., the arbitrary construction of their boundaries by external powers and the

${ }^{417}$ Aves, 1995, p. 209. 
lack of societal cohesion, the states of Caucasus were weak states in their early years of independence. Their appearance as independent states has been viewed more as the consequence of the collapse of the Soviet Union than as the expression of local desire to establish independent states.

The state-building process affects the development of foreign policy for the newly independent states. In other words, the creation of legitimate and effective state structures can organize and mobilize societies and define clear-cut goals for foreign policy. These features, however, did not exist when the Soviet Union collapsed. Therefore, all three Caucasus states tried to accomplish the following tasks: securing independence, breaking their dependence on Russia, obtaining diplomatic recognition form the international community, and establishing direct bilateral relations with other states. ${ }^{418}$

Thus, the analytical construct of a regional and domestic security complex is very much relevant and suitable to the Caucasus, and is helpful in defining the place of the Caucasus states in the international system. Moreover, the dissolution of the Soviet Union created geopolitical vacuum and domestic political conflicts within these states. For instance, the relationship between Armenia and Azerbaijan directly developed into a zero-sum game in which both states aimed at receiving outside support for their war effort towards the other. In another case, Georgia has dealt with separatist ethnic conflicts and power struggles within the political elites as well as Russian involvement in the domestic politics of Georgia. ${ }^{419}$ Hence, the three South Caucasus states' relationships with one another and with the major powers were to have significant negative influences on the region; moreover, Russia as the ex-imperial center and current major regional

\footnotetext{
${ }^{418}$ Aves, 1995, p. 211.

${ }^{419}$ Cornell, 2001, pp. 24-25.
} 
power has played a significant role which has affected these newly independent weak Caucasus states and their position in the international system.

As a result, the Caucasus states, new and weak, have started off very fragmented and unstable and very open to the external influence of major powers. Realism's unitary rational actors, i.e., the Caucasus states, were facing international and regional as well as domestic competition for the direction of their foreign policy choices. Therefore, realism cannot fully explain their foreign policy behaviors. Hence, the understanding of the statebuilding process of these states is very important in explaining their foreign policy objectives and possible options as well as the relations between these objectives and their state capacities. Indeed, there are two dominant models of Caucasus foreign policy analysis. In the first, or 'leader-dominant model', individual leaders are seen as the most important variable to explain choices of foreign policy. It is a model in which leaders of weak and dependent countries translate their personal idiosyncrasies into the foreign policies of their states. ${ }^{420}$ The second model might be called the 'domestic vulnerability model' ${ }^{421}$ This model assumes that weak states, facing greater threats at home than abroad, adopt nationalistic or rhetorical foreign policies to pacify and/or satisfy domestic opinion. In both cases the premises of realist foreign policy are abandoned. ${ }^{422}$

Both internal and external threats have delayed efforts to complete state-building processes and establish effective and stable state institutions. This provides leaders with

\footnotetext{
${ }^{420}$ Christopher Clapham, Third World Politics: An Introduction (Madison: University of Wisconsin Press, 1985), especially pages 47 to 48 and 71 to 77 .

${ }^{421}$ Peter Calvert, The Foreign Policy of New States, (Sussex: Wheatsheaf Books, 1986), especially pages 53 to 78; and Stephen R. David, "Explaining Third World Alignment," World Politics, January 1991, vol. 43, no. 2, pp. 233-256.

${ }^{422}$ Raymond Hinnebusch, The International Politics of the Middle East (Manchester: Manchester University Press, 2003), p. 7.
} 
greater autonomy to make decisions and greater capacity to implement them. Therefore, as such, in explaining newly independent states' foreign policy-behavior, it is necessary to differentiate their levels of state building. The process and options of newly independent states' foreign policies are closely connected with their level of statebuilding and domestic political development. ${ }^{423}$ The foreign policy behaviors of the Caucasus states are hence shaped by both internal and external factors and the state building process which these states experienced in the early 1990s.

Furthermore, external support may serve as important leverage for domestic political struggles. In other words, external support for political and ethnic groups in a weak state is important for successful domestic results. In reality, many foreign relations established by the governments of the Caucasus states can be considered as providing a source of alternative power to deal with domestic challengers. Therefore, foreign policy choices are often derived from a need to strengthen the position of leadership for these countries.

Moreover, foreign policy choice may also be related to domestic political order in which the political order is affected by ethnic minorities who have an affinity with either a neighboring state or a major power. Besides, insurgencies and ethnic separatist movements have frequently spilled over across national boundaries to fuel conflict with neighboring states. Such minorities and threats are very common within the Caucasus in varying concentration. These types of domestic conflicts in the Caucasus were often responsible for interstate as well as intrastate confrontations and conflicts (between Armenia-Azerbaijan, Georgia-Russia).

\footnotetext{
${ }^{423}$ Hinnebusch, 2003, pp. 7-8.
} 
Another aspect of the Caucasus states' foreign policy concerns the roots of threats to the states in the region. The roots of threats in the Caucasus are to be found in weak state structures. These threats include internal fighting among the political elites and ethno-territorial unrest in these countries. The Caucasus states lack a clear division of the state's territorial dimensions from their ethnic and societal compositions, with the exception of Armenia. Moreover, these states entered the international and regional system without having any serious experience of statehood. Therefore, the priority of these states during the 1990s was to stay independent. In other words, sheer survival not just for the Caucasus states themselves but for their leaderships, is the main force driving Caucasus-state foreign policy in this time period. The reason is that the new states of Caucasus are heirs to a conflictual historical legacy. Due to their relative weaknesses as well as to the tensions among them, the historical legacy has often urged the states of the Caucasus to seek outside alliances rather than to cooperate and unite.

In conclusion, the three Caucasus states could not clearly define their national interests in their first years of independence. There was a real confusion between national interests and personal interests of these countries' leaderships. Otherwise, these states had various opportunities to seek and obtain support from global and regional major powers. All of them were weak states located in a region in which much more powerful neighbors and major powers competed for domination. These weak states were looking for opportunities to benefits from this competition of global and regional major powers. ${ }^{424}$ Each Caucasus state developed its own foreign policy based on the factors which were meant before.

${ }^{424}$ Aves, 1995, p. 224. 


\section{Armenia}

\section{3a. The Foreign Policy-Making Process}

The Soviet 'indigenization' policy and ethno-territorial division of the country created ethno-territorial union republics such as the Armenian Soviet Socialist Republic (SSR) in the 1920s. This division legitimized the titular national groups having their own recognized union republic, national territory, and governmental apparatus. Some union republics, however, began to demand more territory from their neighboring republics based on national claims, such as those of the Armenian SSR versus the Azerbaijani SSR and the Uzbek SSR versus the Kyrgyz SSR. They demanded that the central Soviet authority in Moscow transfer control of claimed territory to them. Therefore, even under the Soviet Union, nationalist-territorial debates continued between Armenia and Azerbaijan.

This legacy of the early years of the Soviet Union has resulted in confusing statebuilding with nation-building after the union republics became independent and sovereign states in 1991, such as in Armenia. Armenian political elites have been identified and claimed links between the contemporary Armenian nation with people who lived during the Ottoman Empire on the territories that now constitute Eastern Turkey as well as Karabagh and Nakhchievan in Azerbaijan. ${ }^{425}$

In parallel with the nationalization of the Armenian SSR, the Armenian Diaspora in the West also went through a similar development. If the Armenian SSR had "Sovietstyle" nation-building, in the Armenian Diaspora in different parts of world, especially in the United States and France, it had "Diaspora-style" nation-building. The 'Diaspora-

\footnotetext{
${ }^{425}$ Hunter, 1994, p. 32.
} 
style' nation-building can be described as a process, which was led by the Armenian diaspora elite, mobilizing Armenian diaspora to be aware of national identity outside a motherland and without state institutions. ${ }^{426}$ Therefore, the newly independent Armenian state defined the 'Armenian nation' broadly to consist of, not only people who live in that state, but the entire Armenian diaspora as well. Thus, Armenian national interests are not only the national interests of the population in Armenia but also include concerns and interests of the Armenian Diaspora, such as the question of the Armenian tragedy in 1915.

Armenia became independent with a number of noticeable weaknesses. First, Armenia is the smallest among the CIS countries. Armenia is also a landlocked country. One of the most substantial weaknesses was the country's geopolitical isolation. The deterioration of the internal situation in Georgia during the first half of the 1990s and Armenia's unfriendly relations with Turkey had made Armenia's physical isolation almost complete. Thus, Armenia's geopolitical location makes external threats the primary challenge of Armenian's foreign policy. As Adalian writes “Azerbaijan is hostile, Turkey is unfriendly, Georgia is in anarchy, and Iran is an international outcast. $" 427$ Therefore, the foreign policy of Armenia is basically dictated by Armenian relations with its neighbors, especially Azerbaijan and Turkey. The main problems between Armenia and Azerbaijan as well as Turkey are: the Karabagh problem and the problematic issue of the 1915 tragedy, and Armenian political nationalist elites' irredentist demands for compensation from and even territorial claims on Turkey.

\footnotetext{
${ }^{426}$ Razmik Panossian, The Armenians: From Kings and Priests to Merchants and Commissars, (New York: Columbia University Press, 2006), p. 292.

${ }^{427}$ Adalian, 1995, p. 310.
} 
Therefore, the national identity of a population has become a powerful determinant of foreign policy orientation. In the case of the Armenians, the way in which their national identity is defined contributes to the isolation of Armenia rather than to its integration in the international system. The strong sense of national identity shapes Armenian foreign policy-behavior, above all driving hostility against Turkey and Azerbaijan among the Armenian political elites. Thus, the aspect of ethnicity as a determinant of political behavior is a major element in Armenian foreign policy thinking. ${ }^{428}$

On the other hand, Armenia has advantages that other Caucasus states lack. The fact that Armenia does not have a border with Russia is an advantage, since it minimizes potential sources of conflict with that country. Furthermore, unlike the other Caucasus states, both the early rise of Armenian nationalism as the dominant political force and the establishment of an Armenian army preceding the independent Armenian state provided significant advantages for Armenia vis-à-vis its neighbors. Furthermore, the political leadership under Ter-Petrossian had pursued a skillful foreign policy to deal with the impact of the country's isolated geopolitical condition. ${ }^{429}$

The five state institutions involved in the foreign policy process in Armenia are: The President's office, the Foreign Ministry, National Security and Defense Ministry, the State Agency for National Security, and Parliament. Independent institutions, such as think tanks or special interest groups have little or no impact on the foreign policy process in the country. Armenia is governed by a presidential system, and the Ministries

\footnotetext{
${ }^{428}$ Charles W. Maynes, “Containing Ethnic Conflict,” Foreign Policy, Spring 1993, no. 90, p. 5.

${ }^{429}$ Aves, 1995, p. 222.
} 
of Foreign Affairs and National Security and Defense are a part of the executive branch. The State Agency for National Security in foreign policy matters also played a significant role during 1990s due to the conflict on its borders. The agency reports directly to the president. That means that Armenia's foreign policy is formulated by the president, his close advisors, and key ministers. The Armenian Parliament is fully concentrated upon domestic issues and is rarely involved in foreign policy-making. ${ }^{430}$

A clear division of labor also emerged in the executive branch in the 1990s. The president mainly conducts relations with Russia. Economic relations with international financial institutions and foreign countries were handled by the prime minister. The foreign minister was most active in conducting relations with the Western states as well as organizations like the CSCE/OSCE and NATO. When Gerard J. Libaridian was the president's senior adviser for foreign policy, he represented Armenia at the CSCE/OSCE negotiations for a resolution of the Karabagh conflict. He also had a prominent role in conducting closed-door diplomacy with Turkey. Because of the continuation of the Karabagh war and the insecurity of Armenia, the defense minister had an active role in the foreign policy-making process as well.

Opposition parties have raised questions about how the government conducted foreign policy. The opposition parties had mainly been playing a hardliner's role by emphasizing nationalism and militancy on the question of Karabagh and relations with Turkey. Many of the opposition groups, whether on the right or on the left, also endorsed closer relations with Russia. The opposition sometimes found opportunities to attack the government's policies because the government had become divided over some foreign

\footnotetext{
${ }^{430}$ Adalian, 1995, p. 324.
} 
policy issues. Two figures, among others, played major roles in these debates because their views challenged the president's position in the early 1990s. ${ }^{431}$ Former Prime Minister Vazgen Manukian supported war against Azerbaijan over Karabagh. ${ }^{432} \mathrm{He}$ resigned from the government in 1992, to return briefly in 1993 as the defense minister. The resignation of the first foreign minister, Raffi Hovannisian, who advocated a hardline policy against Turkey, also occurred over foreign policy differences with the president.

One of the important tactics of weak states in their effort to win a major power to their side is their appeal to public opinion of that major power. Weak states try to influence the political elites of the major power or create sympathy among the public of the major powers. For instance, the Armenian Diaspora, especially in the United States and France, is a significant factor influencing these countries' foreign policy concerning Armenia. The Armenian Diaspora has made use of its lobbies to induce major western powers to support Armenia and the Armenian cause. In the initial years after Armenian independence there was excitement both among the people in Armenia and the Diaspora that Armenia could become an extension of the West in the Caucasus and enjoy outside assistance similar to that received by Israel in the Middle East. ${ }^{433}$ However, this was a short-lived feeling that did not correspond to realities.

The Armenian Diaspora is always highly sensitive to the question of the tragedy of Armenians in the late Ottoman Empire era, its recognition by Turkey, and possible

\footnotetext{
${ }^{431}$ Adalian, 1995, p. 314.

${ }^{432}$ Adalian, 1995, p. 315.

${ }^{433}$ Mehmet Tutuncu, “Turkey’s Foreign Policy in the Caucasus," Turkistan Newsletter, Special Issue, 23 June 1997, vol. 97-1, no. 14a.
} 
compensation and even territorial claims. The Armenian 'genocide' claims are the work of nationalists among the Armenian Diaspora and political elites in Armenia. They are the most vocal of the Armenian groups. The Armenian Diaspora has been able to bring the problematic historical experience with Turkey to the forefront of the Armenian foreign policy agenda. The Armenian leadership cannot ignore these sensational issues directly fueled by the Diaspora. ${ }^{434}$ The reason is that the Armenian diaspora, since the late 1980s, has supplied significant financial support for the Karabagh struggle as well as for Armenia as a whole. The Armenian Diaspora has opposed the oil lobby in the West, which advocates Azerbaijani interests in Western capitals. ${ }^{435}$ For example, the Armenian lobby in the United States successfully pushed the American Congress to pass a resolution denouncing Azerbaijan, and even restricting U.S. aid to that country.

The inclusion of diaspora Armenians in the government has been a subject of debate both in and out of Armenia. Ter-Petrossian sought to establish close relations with the Armenian Diaspora, especially those in the United States, and invited a number of the Armenian diaspora members to assume positions in the government. These included: Rafii K. Hovannisian, the first minister of foreign affairs; Sebouh Tashjian, minister of energy; Vartan Oskanian, deputy minister of foreign affairs and later minister of foreign affairs under the Kocharian government; Gerard J. Libaridian, senior advisor to the president and secretary of the Security Council and later deputy minister of foreign affairs. ${ }^{436}$ In addition to these people from the United States, Ter-Petrossian hired

\footnotetext{
${ }^{434}$ Salpi H. Ghazarian, "Distinguishing Between Politics and Policy: An Interview with Jirair Libaridian," Armenian International Magazine, 30 June 1996, vol. 7, no. 5-6, p. 22.

${ }^{435}$ Masih and Krikorian, 1999, pp. 110-111.

${ }^{436}$ Payaslian, 2007, p. 201.
} 
Karabagh Armenians for important ministerial and the other governmental posts:

Kocharian, as prime minister and Sarkissian as defense minister. ${ }^{437}$

Libaridian, Kocharian and Sarkisian especially represented the growing complexity of Armenian politics and the interesting team of people Ter-Petrossian gathered. The Armenian government was leaving foreign policy in the hands of diaspora members who were priori strongly hostile to Turkey and Azerbaijan, making it especially difficult for Armenia to develop good relations with those countries. Indeed, speculation on the resignation of Hovannisian has centered on his conduct of relations with Turkey: Hovannisian elevated the question of Turkish recognition of the Armenian 'genocide' to a condition for establishing diplomatic relations with Turkey. ${ }^{438}$

Serzh Sarkissian is also an interesting figure who joined the Armenian government from the outside. In Sarkissian's case, Karabagh is home; there he had commanded the Karabagh forces and then was elevated to the post of defense minister of Karabagh before Ter-Petrossian appointed him as the defense minister of Armenia. ${ }^{439}$ With Kocharian, he came to symbolize the mutual identification of Armenia and Karabagh. His role as the defense minister of Armenia made him part of the foreign policy-making process, especially on the Karabagh issue. His appointment could only imply a toughening of the Armenian position and a greater tendency toward the militarization of Armenian foreign policy. ${ }^{440}$

\footnotetext{
${ }^{437}$ Payaslian, 2007, p. 213.

${ }^{438}$ Adalian, 1995, p. 325.

439 Adalian, 1995, p. 325; Masih and Krikorian, 1999, p. 49; and Payaslian, 2007, p. 213. Sarkissian held prime minister position under the Kocharian government. In March 2008 controversial presidential elections, he ran against Ter-Petrossian and won the election in Armenia.

${ }^{440}$ Adalian, 1995, p. 326.
} 
Armenia's success in dealing with threats to its national security had also been a result of the country's political stability, certainly compared to the situation in the other two Caucasus states in the 1990s. Armenia achieved a stable presidential succession in 1998. Despite the constitution granting the president the power to dissolve the parliament under certain conditions, to appoint the prime minister, to declare martial law, and to carry out with full authority the foreign policy of the state, real power was distributed among senior ministers rather than concentrated entirely in the hands of the president. In particular, the political standing of the power ministries and Karabagh veterans helped to ensure stability and a comparatively smooth transition of presidential office from TerPetrossian to Kocharian. ${ }^{441}$ The Karabagh conflict is, therefore, the most important element for the Armenian domestic political structure as well as foreign policy.

When Gorbachev declared his Glasnost policy in the late 1980s, both Armenian ruling-communist and dissent-nationalist opposition elites raised the question of Karabagh. The creation of Armenian paramilitary groups began in late 1980s. In early 1990s, the members of the Karabagh Committee obtained de facto power and quickly consolidated their leadership in Armenia. In July 1992 the State Defense Committee was set up by the Armenian leadership to concentrate all political and military power in a single authority. All paramilitary groups came under the control of the Armenian government to fight in Karabagh. As a result, the Karabagh issue was elevated as the pillar of Armenian nationalism and raison d'être for establishing Armenian army. ${ }^{442}$

\footnotetext{
${ }^{441}$ Herzig, 1999, p. 30.

442 Jonathan Aves, "The Caucasus: The Regional Security Complex," in Security Dilemmas in Russia and Eurasia, Roy Allison and Christopher Bluth, eds., (London: The Royal Institute of International Affairs, 1998), p. 183.
} 
Ter-Petrossian as the chair of the Karabagh Committee and later the first president of independent Armenia unified all Armenian paramilitary groups into a new national army and mobilized them for the Karabagh cause. Thus, the Karabagh conflict, in both military and political terms, was the first source of establishing state institutions in Armenia and securing the legitimacy of Ter-Petrossian's power as the president of the country. The Armenian military become the essential institution in the Armenian statebuilding process. The Ministries of Defense and Interior increased their influence on Armenian domestic and foreign politicies and turned into "power ministries.",443

The Karabagh issue also facilitated the emergence of a new generation of Armenian leadership and political elite led by Ter-Petrossian. Facing many problems, the new leadership concentrated on how to deal with the Karabagh issue and securing the sovereignty of Armenia against potential threats, given that the Karabagh issue is linked with potential and actual threats which the Armenian leadership faces from Turkey and Azerbaijan. $^{444}$

On the one hand, in military terms, the Karabagh conflict was settled, at least temporarily, by the summer of 1993. Armenian forces occupied all of Karabagh and then went on to occupy more land outside the contested territory, estimated by Azerbaijani government at 20 percent of the country. ${ }^{445}$ The success of Armenian military forces

\footnotetext{
${ }^{443}$ Ian Bremmer and Cory Welt, “Armenia's New Autocrats,” Journal of Democracy, 1997, vol. 8, no. 3, p. 81.

${ }^{444}$ Taline Papazian, "From Ter-Petrossian to Kocharian: Explaining Continuity in Armenia Foreign Policy, 1991-2003,” Demokratzatsiya, Spring 2006, vol. 14, no. 2, p. 236.

${ }^{445}$ Charles King, “The Benefits of Ethnic War: Understanding Eurasia's Unrecognized States,” World Politics, July 2001, vol. 53, no. 4, p. 536.
} 
against Azerbaijani forces and the occupation of Karabagh and surrounding regions of Azerbaijan obviously secured full public support for the Ter-Petrossian government.

On the other hand, the military victory in Karabagh hardened public opinion, which rejected any compromise for dealing with Azerbaijan, as well as escalated public expectations from the Ter-Petrossian government. Furthermore, the occupation of Azerbaijani territory by the Karabagh Armenians beyond Karabagh and the nearly one million Azerbaijani refugees forced to leave their homes as a result of Armenian occupation, have undercut the sympathy of the international community for Armenia and contributed to the country's growing international isolation. This has hindered Armenian foreign policy by imposing increasing limits on foreign policy options and opportunities.

Besides their attempts to influence foreign public opinion in their favor, weak states try to strengthen the commitment of a major power by inviting the stationing of its troops and maintainance of its bases on their territories as well as supporting the major powers' operations in different parts of the world. ${ }^{446}$ The intention is to have the troops of a major power act as a security barrier or insurance and guarantee automatic intervention if the weak state were to be attacked. Russian troops in Armenia play this role. Because Armenia felt vulnerable along its borders with Turkey, it accepted a joint RussianArmenian border defense. Yet one of the issues questioned by the Armenian political elites is the difficulty of knowing what choices for security protection are really on offer from Russia. ${ }^{447}$ For example, toward the end of 1993 Russia followed Turkey’s approach

\footnotetext{
${ }^{446}$ Armenia, Azerbaijan and Georgia have a small number of military personnel in Iraq and Kosovo. Azerbaijan and Georgia also have a small number of military personnel in Afghanistan. See, Jim Nichol, "Armenia, Azerbaijan, and Georgia: Security Issues and Implications for U.S. Interest," Congressional Research Service, 31 January 2008.

${ }^{447}$ Martha B. Olcott, "Sovereignty and the 'Near Abroad'," Orbis, Summer 1995, vol. 39, no. 3, p. 364.
} 
and accused the Armenian government as ultimately responsible for the actions of the Armenian forces fighting in Karabagh. ${ }^{448}$ For that reason, the Armenian leadership found itself in a complicated situation in 1993 and 1994. The Armenia leadership believed that it required bandwagoning with Russia to become a member of the CIS in order to protect itself against a real threat from Azerbaijan and a potential threat from Turkey. However, after the victory Armenia achieved at Azerbaijan's expense in Karabagh, the Armenians felt more secure. The Armenian government also realized that Armenia needs to develop relations with the other major powers in the region. In short, Russia pursued the consolidation of an alliance with Armenia because of the historical ties with Armenia and the desire to retain a presence in the Caucasus.

As Vazgen Manukian, then Armenian Defense Minister, admitted, "our foreign policy is focused on what support we can give the Armenians of Nagorno-Karabakh". 449 Thus, Armenian foreign policy has been guided since 1988 almost exclusively by its war with Azerbaijan over Karabagh. The war has decisively shaped Armenian foreign policy options yet it has simultaneously polarized the country's foreign policy establishment, such as with three different foreign ministers being named in the winter of 1992-93. ${ }^{450}$

The annexation by the Karabagh Armenians of large territory beyond Karabagh damaged Armenian standing in the international community and contributed to the country's growing international isolation. Because of the economic embargo imposed by Azerbaijan and Turkey, the Armenian government experienced serious economic

\footnotetext{
${ }^{448}$ Elizabeth Fuller, "The Transcaucasus: War, Turmoil, Economic Collapse,” RFE/RL Research Report, January 1994, vol. 3, no. 1, p 52.

${ }^{449}$ Phillip Petersen, "Security Policy in Post-Soviet Transcaucasia," European Security, Spring 1994, vol. 3, no. 1, p. 30.

${ }^{450}$ Snark, 26 February 1993, in FBIS-SOV, 1 March 1993, p. 69.
} 
difficulties. Ter-Petrossian believed that the only way to decrease Armenian dependency on Russia and connect to the Western world passed through Turkey. For this reason, TerPetrosian's government tried to establish normal relations with Turkey but while there had been some progress on the diplomatic front, Turkey had stopped short of opening its border with Armenia in any significant way because of strong popular support for Azerbaijan in Turkey. Relations with Iran have traditionally been better but these too have been put under strain by developments in the Karabagh war as well as the U.S. policy on Iran. Only relations with Russia have improved with a growing perception of shared interest vis-à-vis Azerbaijan and Turkey. ${ }^{451}$

\section{3b. Leadership Perceptions on Foreign Policy}

\section{Levon Ter Petrossian (1991-1998)}

When Armenia emerged as an independent state, its first president Levon TerPetrossian faced a complicated task as he tried to develop an independent foreign policy. Armenia suffers from some geopolitical disadvantages and limited natural resources but it also has advantages that other Caucasian states lack. The fact that Armenia does not have a border with Russia is an advantage, since it minimized a total dependency on Russia as well as a potential source of conflict with Russia, but in overall terms the Armenian isolation from its only real ally, Russia, is a disadvantage. ${ }^{452}$

Since Ter-Petrossian led the 'Karabagh Committee' in the late 1980s, he utilized the Karabagh issue and acquired both popular appeal and legitimacy for his presidency until the middle of the 1990s. In other words, the Karabagh conflict was the first and

\footnotetext{
${ }^{451}$ Gareth M. Winrow, Turkey and Caucasus: Domestic Interests and Security Concerns, (London: The Royal Institute of International Affairs, 2000), pp. 10-14.

${ }^{452}$ Aves, 1995, p. 222.
} 
most important source of legitimacy for the Ter-Petrossian leadership. Armenian nationalist and communist elites, as well as the Diaspora supported his leadership and his foreign policy objectives. These objectives were the continuation of Russian support, securing sovereignty of Armenia, keeping good relations with the Armenian diaspora, and backing Karabagh independence from Azerbaijan. Ter-Petrossian's early foreign policy, therefore, was based on coordinating policy with Russia, which provided material support for the Karabagh war and securing full support of the Armenian political elites both in and out of the country. Therefore, Ter-Petrossian had to consider the preferences of the Armenian mainstream and Diaspora political elites. With a ceasefire in 1994 between the Armenian and Azerbaijani forces, the Karabagh conflict was simply frozen. In this time period, he consolidated his power with a new constitution and presidential election. ${ }^{453}$ With the constitution, he tried to accumulate all political power in his hands. He started to deal with his competitors and opponents. First, he shuffled those of his ministers who could be potential challengers, such as Vazgen Manukian. Second, he closed down the opposition party, ARF, and newspapers.

In the middle of the 1990s, Ter-Petrossian, when Armenia was facing domestic political and economic crisis, realized that he had to consider not only the position of the Armenian political elite and leadership of Karabagh but also the preferences of the international community, the United States, Russia and the OSCE Minsk group, as well as Turkey and Azerbaijan. He tried to explore alternatives for Armenia, such as decreasing Armenia's strategic direction from total dependence on Russia and looking for a way toward reconciliation with Turkey. This was a difficult challenge. In this time

\footnotetext{
${ }^{453}$ Alexander Markarov, "Macro Institutional Political Structures and Their Development in Armenia," Demokratizatsiya, Spring 2006, vol. 14, no. 2, p. 162.
} 
period, Ter-Petrossian's attention also shifted from the Karabagh problem to Armenia's immediate economic and domestic challenges. In other words, Ter-Petrossian decided to try to weaken dependency on Russia and open relations with Turkey as well as making compromises on Karabagh to Azerbaijan so that Armenia might benefit from the Caspian oil deal. ${ }^{454}$

Ter-Petrossian's government also attempted to make a diplomatic maneuver on Karabagh, admitting its material support for the Karabagh Armenians but denying any direct military involvement. Talk of political union between Armenia and Karabagh had been dropped and the Ter-Petrossian government refused to recognize the self-declared republic of Karabagh, stating that the Karabagh issue should be solved between Karabagh Armenians and Azerbaijani government. The Armenian government would thus recognize any agreement reached between Azerbaijan and the Karabagh Armenians. This stance represented a significant shift from Ter-Petrossian's earlier positions and had led to strained relations with the Karabagh leadership. Moreover, the Ter-Petrossian leadership resisted demands, mostly originating from the Diaspora, that Turkish recognition of the "genocide" " be placed at the top of the foreign policy agenda. Armenia also joined the Turkish initiated Black Sea Cooperation Organization, and TerPetrossian attended the funeral of late Turkish president, Turgut Ozal. ${ }^{455}$

\footnotetext{
${ }^{454}$ See, Libaridian, The Challenge of Statehood: Armenian Political Thinking Since Independence, (Watertown: Blue Crane Books, 1999), p. 117. Libaridian expressed that relations with Turkey should go beyond the 'genocide' and normalization of relations with Turkey would be beneficial to both Armenia and Turkey:

“..., what if having normal diplomatic and economic relations with Turkey is in the interest of Armenia as well as of Karabagh? Would not improved Armeno-Turkish relations weaken the Azerbaijani negotiating position, the rigidity of which is based on a policy of strangling the Armenian economy? Should the answer to these questions be positive, ...then the normalization of relations with Turkey would facilitate Armenia's role as a transit route of Caspian Sea hydrocarbon resources.”

${ }^{455}$ Aves, 1995, p. 230.
} 
One of Ter Petrossian's most controversial initiatives had therefore been his attempted rapprochement with Turkey. The Azerbaijani closing of a pipeline supplying 80 percent of Armenia's gas had forced Erevan into unsafe dependence on a single pipeline, which had been routinely sabotaged, running through an Azerbaijani-populated region of Georgia. Armenian discussions with Turkey have yielded limited results; a Turkish decision to supply Armenia with electricity was reversed following intense domestic and Azerbaijani criticism. Turkey briefly allowed humanitarian shipments of food and fuel to transit its territory to Armenia but terminated the relief operation following Armenian offensives in western Azerbaijan in April 1993. ${ }^{456}$

Furthermore, the Ter-Petrossian government's attempt to fully normalize bilateral relations created a positive atmosphere between Turkey and Armenia. A large delegation of the Union of Industrialists and Entrepreneurs of Armenia headed by Armenian President's brother, Telman Ter-Petrossian, visited Turkey. Telman Ter-Petrossian expressed that economic relations and cooperation might begin even before diplomatic relations could be established. ${ }^{457}$ Deputy Foreign Minister of Armenia Vartan Oskanian believed that "such visits of representatives of business and industrial circles may lay grounds for political and diplomatic relations. ${ }^{, 458}$ While there had been some progress on the diplomatic level, Turkey had stopped short of opening its border with Armenia in any significant way because of strong popular support for Azerbaijan among Turkish

\footnotetext{
${ }^{456}$ Suha Bolukbasi, “Ankara's Baku-Centered Transcaucasia Policy: Has It Failed?” Middle East Journal, 1997, vol. 51, no. 1 , p. 84.

${ }^{457}$ Burcu Gultekin, The Stakes of the Opening of Turkish-Armenian Border: The Cross-border Contacts Between Armenia and Turkey, (Istanbul: French Institute of Anatolian Studies, October 2002), p. 45.

${ }^{458}$ Armen Khanbayan, "Opening of the Border with Turkey is Beneficial for Both Sides," Nezavisimaya Gazeta, 20 August 1996, no. 153, Armenian News Network, accessed 20 August 1996.
} 
political elites and public. Therefore, in spite of the Ter-Petrossian government's attempt to distance itself, Karabagh remained the central issue of the Armenian foreign and domestic politics. ${ }^{459}$ In other words, the conventional explanation for this shift of TerPetrossian's foreign policy was that Armenian's long-term security and economic recovery depended upon a settlement as well as yielding to pressure from the international community, particularly the United States, to make concessions over a Karabagh settlement. Moreover, as a pragmatic leader, Ter-Petrossian understood that the Karabagh issue should be resolved; otherwise Armenia would lose a major opportunity from the Caspian hydrocarbon boom and become an isolated country in the region with few prospects. Armenia needed Turkey to open up its border and allow transportation to pass through Turkey to Armenia. Ter-Petrossian had feared that Azerbaijan's natural resources, oil and gas provided leverage for Azerbaijan to improve its economic and military capacity to prepare another war against Armenia. ${ }^{460}$

Another indication of the pragmatist approach of Ter-Petrossian was that he admitted that Yeltsin's support of the principle of territorial integrity weakened Armenia's position in the Karabagh peace process, but added that "we have no illusions in that regard; because Russia could not act differently... it has its own twenty Karabaghs. ${ }^{, 461}$

\footnotetext{
${ }^{459}$ Natalya Airapetova and Armen Saakyan, "Yeltsin and Ter-Petrosyan Sign Friendship Treaty- Document Opens New Stage of Strategic Partnership between Moscow and Yerevan," Nezavisimaya Gazeta, 30 August 1997, p.3 in The Current Digest of the Soviet Press, 1997, vol. XLIX, no.35, p.16-17.

${ }^{460}$ Masih and Krikorian, 1999, p. 111; and Croissant, 1998, pp. 131-132.

${ }^{461}$ Edward Walker, No Peace, No War in the Caucasus: Secessionist Conflicts in Chechnya, Abkhazia and Nagorno-Karabakh, (Cambridge: SDI, 1998), p. 33; and Statement: President Levon Ter-Petrossian National Security Council Session, 7-8 January 1998, p. 18.
} 
Under the leadership of Ter-Petrossian, Armenian foreign policy was driven by a small number of advisors of the president based on pragmatic needs of both domestic and external circumstances. Libaridian, one of the most influential advisors to Ter-Petrossian, said that Armenia should cooperate with Georgia and Azerbaijan to foster confidence and create the possibility of reaching a conclusive peace in the region. Furthermore, Libaridian, as the architect of Turkish-Armenian relations in the midst of the 1990s, emphasized that if relations between Turkey and Armenia were to improve, this in turn would help solve other existing issues, including the Azerbaijani-Armenian problem. $\mathrm{He}$ also said that the "close identification of Azerbaijan with Turkey made Azerbaijan an extension of Turkey in the minds of the Diaspora Armenians. The occupation of Azerbaijani territories was also perceived by many Diasporas as the rightful revenge of the past. There are those who believe that the return of these territories would constitute treason..."462

The uneasy period of 'neither peace nor war' after the 1994 ceasefire in Karabagh allowed an opportunity for Ter-Petrossian to shift his foreign policy orientation. Meanwhile, however, the nationalist political elite also shifted its attention to accumulate and consolidate more power in domestic politics and securing their position in the government. The Defense Minister Sarkisian, who commanded the Armenian army in Karabagh, and Kocharian were two leading figures from these elites and were both from Karabagh. Kocharian, former leader of the Karabagh Armenians, was appointed as the

\footnotetext{
${ }^{462}$ Libaridian, 1999, p. 144.
} 
Armenian Prime Minister by Ter-Petrossian after the controversial presidential election in 1996 keeping the support of the nationalist elite and Armenian Diaspora. ${ }^{463}$

The Minsk Group co-chairs (the United States, Russia, and France) submitted a proposal in May 1996. Ter-Petrosisian and his Azerbaijani counterpart Aliyev agreed on this plan. This plan was the most controversial initiative taken by Ter-Petrossian. Under the plan of the Minsk Group, Armenian forces would be withdrawn from Kelbadjar and five other occupied Azerbaijani regions outside of Karabagh and displaced Azerbaijani populations would return to their homes. The Armenian forces would then withdraw from the Karabagh town of Shusha and the Lachin district where international peacekeepers under the OSCE aegis would be deployed. ${ }^{464}$ This plan was rejected by the Armenian political elite. In particular, there was a strong opposition to the Minsk Group's "step-bystep" approach to settlement, in which a withdrawal of Armenian forces from most of the districts they are occupying in Azerbaijan proper and various security arrangements would precede an agreement on Karabagh's legal status and relationship with Baku. ${ }^{465}$

Ter-Petrossian concluded that the proposal was reasonable and that Armenia's economic recovery, and hence its long term security, depended upon a settlement. Armenia needs Turkey to open up its border and allow rail traffic to resume passage to Middle Eastern and European markets, but Ankara has made it clear that it will continue its blockade until there is a first stage settlement. However, talk about a "peace

\footnotetext{
463 “Armenia: Nagorno-Karabakh President Appointed Premier by President,” Interfax, 20 March 1997, World New Connection.

464 "Gradual Solution of Karabakh Problem Is Realistic, Says Armenian Presidents," ITAR-TASS, 1 September 1997; and Sevindzh Abdullayeva and Viktor Shulman, "Aliyev Welcomes Proposals of Minsk Group Co-Chairmen," ITAR-TASS, 7 October 1997, World News Connection.

465 "Vartan Oskanian, Armenia's Deputy Foreign Minister, Makes Assessment of Country's Foreign Policy Achievements," Armenian Reporter International, 17 January 1998, vo. 31, no. 16, p. 22.
} 
pipeline" ${ }^{466}$ and Azerbaijani oil explains the international pressure on Armenia to compromise and made Ter-Petrossian vulnerable. Thus, Ter-Petrossian's foreign policy shifts alienated him from both the nationalist political elites and the Diaspora.

Ter-Petrossian stated that economic concerns necessitate a speedy resolution to the conflict to ensure his country is not isolated in the region. "The unresolved state of the Karabagh question is not in the interests of Karabagh or Armenia because it is palpably hindering the economic development of Armenia," he wrote in an article. "The only option now is a compromise. We can't wait because Armenia and Karabagh are strong today, but in a year or two we'll be substantially weakened." But Ter-Petrossian's pragmatic position was rejected by opponents insisting on no compromises on Karabagh. The president even faced resistance in his own government from Prime Minister Robert Kocharian who opposed a step-by-step agreement. ${ }^{467}$

Beginning in late 1997, Kocharian and the Defense Minister had begun openly opposing Ter-Petrossian's decision to accept the OSCE Minsk Group's proposal for a first stage settlement of the conflict over Karabagh. Kocharian made clear to TerPetrossian that he would not resign if the president attempted to remove him from office, and that he had the support of the key "power ministries." Ter-Petrossian's willingness to accept the Minsk Group's proposal "as a basis for negotiation" separated the president from his former allies. ${ }^{468}$ Thus, the Karabagh issue was converted from an issue of national security into an issue of regime security.

\footnotetext{
${ }^{466}$ Croissant, 1998, pp. 132-133; Masih and Krikorian, 1999, pp. 126-128; and LeVine, 2007, p. 221.

${ }^{467}$ Selina Williams, "Holdout Imperils Talks on Caucasus,” Los Angeles Times, 17 December 1997, Armenian News Network, groong@usc.edu, accessed by 17 December 1997.

${ }^{468}$ Edward W. Walker, “Armenia's Constitutional Coup and the Karabakh Conflict,” Analysis of Current Events, March/April 1998, vol. 10, no. 3-4, http://socrates.berkeley.edu/ bsp/caucasus/articles.html.
} 
Instead, Kocharian and Sargsian endorsed the Karabagh Armenian leader Arkadii Ghukasyan's proposal, which suggested that Karabagh and Azerbaijan should establish 'horizontal relations' with the approval of the international community. Ghukasyan insisted that Armenians would not return either Shusha or Lachin to Azerbaijan because those districts are vital for Karabagh Armenian security. This clearly indicates that there was a disagreement between the President and his cabinet members in the late 1997s. ${ }^{469}$

Thus, Ter-Petrossian's attempt to apply pressure to the Karabagh Armenians failed due to the efforts by key Armenian political elites, especially Karabagh Armenians, who had high governmental positions, such as Kocharian as prime minister, Sarkissian as defense minister as well as Karabagh war veterians. Moreover, many Armenians viewed the Karabagh issue as a sacred issue. Ter-Petrossian's domestic position became shaky. He was already accused by opposition forces and international observers of rigging the 1996 presidential election. ${ }^{470}$ Under these conditions, Ter-Petrossian resigned his post and his Prime Minister Robert Kocharian, a nationalist from Karabagh, became the president of Armenia.

\section{Robert Kocharian (1998-2008)}

Kocharian's presidency symbolized the significance of the Karabagh issue to Armenian politics. Under his leadership, Armenian foreign policy was driven by more nationalist political elites. Upon assuming the presidency, Kocharian appointed a number of opposition parties' leaders as his advisors, such as Leader of ARF, Vahan

\footnotetext{
469 “Approaches to Resolving Karabakh Conflict Clarifies,” RFE/RL Newsline, 23 October 1997, vol. 1, no. 145; and Payaslian, 2007, p. 212.

${ }^{470}$ Lawrence Sheets, “Armenian Policy Switch Fuels Talk of Karabagh Deal,” Reuters, 23 October 1997, Armenian News Network, groong@usc.edu, accessed by 23 October 1997.
} 
Hovannisian. ${ }^{471}$ These ruling elite fostered the dominance of nationalism over pragmatism in Armenian foreign policy. Kocharian developed a contradictory foreign policy approach. He declared that the issue of international recognition of the 'genocide' would be one of the key goals of Armenian foreign policy; at the same time, he also claimed that he would continue the policy of Ter-Petrossian to pursue normalization with Turkey.

Kocharian criticized Ter-Petrossian for alienating potential investors in the Diaspora by refusing to adopt Turkish recognition of the 'genocide' claim as part of the Armenian foreign policy agenda and banning the ARF, the most organized party in the Diaspora. Kocharian reinstituted the legitimacy of ARF. He believed that the Diapora could replace international investment and helped break the country's international isolation. ${ }^{472} \mathrm{He}$ concluded that Armenian economic prospects would not be influenced by lifting the Azerbaijani-Turkish embargo and that Armenia would be able to preserve its military advantage over Azerbaijan.

He and his advisors also perceived a parallel between the conflict with Turkey in 1918-1921 and the Karabagh conflict with Azerbaijan from 1991-1994. Moreover, they believed that the Azerbaijani government lacked the will and capacity to retake Karabagh by force. ${ }^{473}$ Oil revenues would allegedly do nothing to improve Azerbaijan's military position, and accordingly the security risk of withdrawing from the occupied district of Azerbaijan was not justified by the potential gain. Thus, Kocharian believed that the

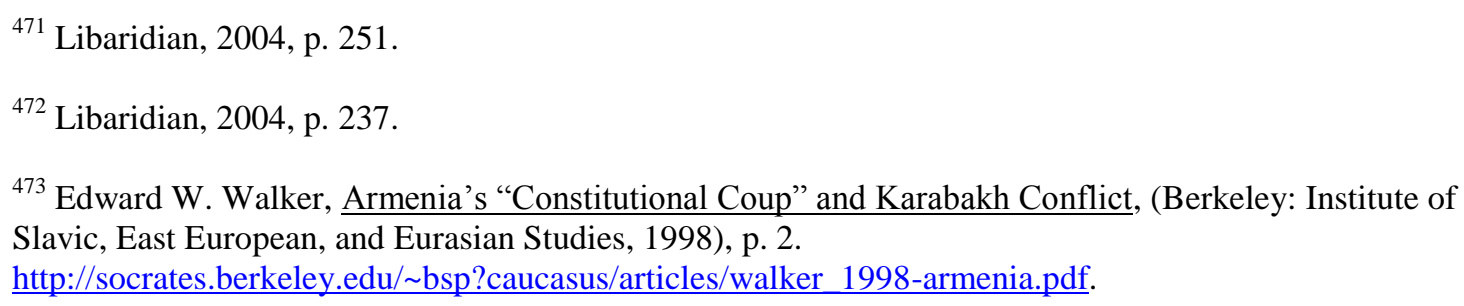


Karabagh issue had in effect been resolved and what was then happening was just a search for international diplomatic recognition. ${ }^{474}$ In effect, he tried to keep the status quo.

Unlike Ter-Petrossian's ad hoc style, Kocharian and his advisors developed close and more organized relations with the Armenian Diaspora. On September 22-23, 1999 in Erevan, 800 members of the Armenian Diaspora for the first time had a conference organized by the Armenian government. Kocharian believed that the Diaspora could help Armenia to ease its economic and political difficulties. For example, the Diaspora funded construction of a road linking Armenia with the capital city of Karabagh. The Kocharian government also changed the Ter-Petrossian government's policy on the 'genocide' issue. The government placed the recognition of the 'genocide' on the foreign policy agenda and supported the Diaspora's efforts toward securing international recognition of 'genocide' claim. The Armenian Diaspora has registered some success in this regard. Some foreign governments and parliaments adopted resolutions for their own domestic political gains and raised the issue within the context of debates regarding Turkey's admission to the European Union, such as Belgium and France. Some western governments urged Turkey to work toward establishing diplomatic relations with and to terminate the economic blockade on Armenia. ${ }^{475}$ However, this campaign put Armenia in a difficult position to normalize relations with Turkey.

Therefore, the first two years of the Kocharian government had not brought any significant changes in Armenian foreign policy. But throughout 1999 there were

\footnotetext{
${ }^{474}$ De Waal, 2003, p. 263.

${ }^{475}$ Payaslian, 2007, pp. 225-226.
} 
indications that Kocharian was shifting his foreign policy. In November 1999, Kocharian attended the OSCE Istanbul Summit. At the end of the summit, a declaration was issued, declaring that the international community supported efforts of the presidents of Armenia and Azerbaijan to resolve the Karabagh conflict through the Minsk Group and recognize Karabagh as a part of Azerbaijan. Unlike the negative assessments of the OSCE Lisbon Summit in December 1996, the Armenian public reacted more favorably. ${ }^{476}$ One of the reasons is the Armenian public attention had already shifted from the Karabagh problem to direct and pressing economic and political crises in the country.

Kocharian and Aliyev had started to take steps forward on the diplomatic settlement, meeting in closed-door sessions and having discussions on the Karabagh issue under mediation of the United States and OSCE. The October 1999 shootings in the Armenian Parliament and the subsequent turmoil in the Armenian ruling elites disrupted these preliminary developments. Armenian internal fighting intensified and shifted the focus of both the ruling elite and the Armenian population at large from the Karabagh issue to these urgent political clashes. ${ }^{477}$

In this circumstance, the parameters of Armenian foreign policy decreased. In other words, these circumstances limited policy options and opportunities and made Armenian foreign policy hostage to the Karabagh issue. Moreover, the difference between Ter-Petrossian and Kocharian was over different assessments of Armenia's perceived national interests. ${ }^{478}$ The disagreement was over different assessments of

\footnotetext{
${ }^{476}$ Hratch Tchilingirian, "The Istanbul Summit: Fifty-Four Nations Discuss Regional Security and Conflict," Armenian International Magazine, 31 December 1999, vol. 10, no. 12, pp. 24-25.

${ }^{477}$ De Waal, 2003, pp. 265-266.

${ }^{478}$ Taline Papazian, "From Ter-Petrossian to Kocharian: Explaining Continuity in Armenia Foreign Policy, 1991-2003," Demokratizatsiya, Spring 2006, vol. 14, no. 2, p. 243.
} 
Armenia's and Karabagh's perceived interests. Kocharian claimed that the international community had been unfairly pressuring Armenia because it wanted to sign oil contracts with Baku. Oil was driving the U.S. policy in the region. However, Kocharian believed that Armenia's economic prospects were reasonable even without a lifting of Turkey's embargo.

The Karabagh peace talks reached a significant level, culminating in the Key West summit, Florida between 3 and 7 April, 2001, at which Aliyev and Kocharian met for a closed-door negotiations under the backing of the United States and OSCE. As cochairs of the OSCE Minsk Group, the United States, Russia, and France were mediators at the talks. Aliyev and Kocharian were close to making an agreement; however, public opinion in Armenia and Azerbaijan rejected any compromise agreement. ${ }^{479}$

\section{3c. Armenia and Russia}

Armenia's most important foreign relationship is with Russia, primarily due to the absence of a regional security framework. Armenian leaders have sought foreign alliances to ease pressure on their country because of unfriendly neighbors like Turkey on the western border and Azerbaijan on the southern and eastern borders. They have looked first to Russia, the country's traditional protector. Russian governments have responded positively to provide security for Armenia. They believe that they have mutual interests in the region. Russia wants to be the only authority in the affairs of the Caucasus and wishes to maintain its economic and political influence. The Russian strategy calls for the

\footnotetext{
${ }^{479}$ Thus, for example, Arkadiy Ghukasyan, the "president" of the self-proclaimed "Nagorno-Karabagh Republic" said during the talks between the then Azerbaijan president Aliyev and his Armenian counterpart Kocharyan in Key West that other options would mean "that we move not toward peace but toward war." See, "Karabakh Leader: Independence or Unification with Armenia”, RFE/RL Azerbaijan Report, 5 April 2001, http://www.rferl.org/reports/azerbaijan-report/2001/04/0-050401.asp.
} 
re-integration of the region within a Russian dominated security system. Thus, Russia initiated both multilateral and bilateral security arrangements with each of the Caucasus states, as they did with the Central Asian states. ${ }^{480}$

However, the expansion of Armenian-Russian relations, while enhancing the Armenian security, limits the chances for Armenia to develop an alternative foreign policy in the region. It makes Armenia virtually totally dependent on Russia. This Armenian dependency entails certain risks. Armenia’s links with Russia lie across Georgia but Georgian-Russian relations have usually been unfriendly. Moreover, Georgia had been in such a state of anarchy that it was unable to secure the Russian connection with Armenia in the early 1990s. Moreover, for Russia, Azerbaijan and Georgia are more important than Armenia. Azerbaijan and Georgia have borders with Russia. Azerbaijan has rich oil and gas reserves. Azerbaijan and Georgia are very important transit countries between Russia and Turkey, and Russia and Iran respectively. These are significant challenges for the Russian alliance with Armenia. ${ }^{481}$

Armenia had received initial assistance from the Russian government under Yeltsin's leadership and moved to bolster a strategic partnership with Russia. Yeltsin supported Armenia, beginning when he was fighting against the Soviet leadership in Moscow in 1990, when he initiated a close relationship with the leaders of the Armenian Nationalist Movement (ANM). Moreover, the Armenian government, unlike its neighbors in Georgia and Azerbaijan, never rejected having Russian military bases on its

\footnotetext{
${ }^{480}$ Andrei V. Zagorski, "Traditional Russian Security Interests in the Caucasus and Central Asia: Perceptions and Realities," in Russia, the Caucasus, and Central Asia: The $21^{\text {st }}$ Century Security Environment, (Armonk: M.E. Sharpe, 1999), p. 69; and Masih and Krikorian, 1999, p. 104.

${ }^{481}$ Masih and Krikorian, 1999, pp. 95-96.
} 
soil and welcomed all Russian multilateral and bilateral initiatives. ${ }^{482}$ For instance, Armenia was one of the original signatories of the May 1992 Collective Security Treaty. At the Tashkent meeting of the CIS, Russia asked the former Soviet Republics to form a CIS collective security alliance. In the Caucasus, Armenia was the first Caucasus state to become a member of the alliance.

During the summit of the CIS in October 1994, Yeltsin and Ter-Petrossian signed the treaty on establishing two Russian military bases in Armenia (Gyumry and Yerevan). This was the first treaty that legalized, on a long-term basis, the basing rights for Russian troops in the former Soviet republics, in contrast to Azerbaijan's attitude of refusing basing rights for Russian forces. Armenia was pleased to have a Russian security support while she waged a war against Azerbaijan. ${ }^{483}$ Armenia needed Russian support for its desire to unite with Azerbaijan's Karabagh region and wanted Russian protection against other regional powers, especially against Turkey. Armenia and Russia jointly secure Armenia's borders. There are 14,000 Russian soldiers in Armenia. ${ }^{484}$ Therefore, for Armenia, the Russian military forces in Armenia were the only reliable guarantee not only against external threats but also against internal threats, thus providing stability within the state. It is unlikely that any Armenian opposition forces would risk moving against an Armenian government that had the full support of the Russian military forces located in the country. This demonstrates the level of Russian-Armenian relations.

\footnotetext{
${ }^{482}$ Gevorg Ter-Gabrielyan, "Making History on Parallel Tracks: Yeltsin, Ter-Petrossian, and the Emergence of Democracy in the Post-Soviet Era," The Armenian Reporter, 5 May 2007, p. A9.

483 Pavel Felgengauer, "Russian Troops Remain in Transcaucasus," Sevodnya, 21 October 1994, p. 2, in The Current Digest of the Post-Soviet Press, 16 November 1994, vol. XLVI, no. 42, pp. 20-21.

${ }^{484}$ Cornell, 1998, p. 58.
} 
Another indicator of Russian-Armenian alliance was that the first official visit of Ter-Petrossian, as the Armenian President, was to Moscow. He signed the ArmenianRussian military treaty, which, in Yeltsin's opinion, reflected "the will and desires of the peoples" of Russia and Armenia "and would hold a special place in the two peoples history." ${ }^{485}$ The visit placed political-military cooperation between Armenia and Russia into a new perspective. A treaty establishing a strategic partnership between Russia and Armenia was ratified by both houses of the Russian parliament and backed up with a status of forces agreement, thereby precluding debate within Armenia on the legitimacy of Russian troops' being there.

Furthermore, Yeltsin called the Armenian-Russian treaty in 1994 "an important step that seals our relations as allies." Under the treaty, the Russian troops stationed in Armenia, which had remained since the days of the USSR, were accorded official legal status. The Armenian-Russian military agreements allowed Russia to have two military bases in Armenia. The Russian Defense Minister's presence at the Armenian-Russian joint military exercises near Nakhichevan and the Turkish border made a particular impression to indicate the level of Armenian-Russian alliance. ${ }^{486}$ Consequently, Armenia's relations with Moscow have traditionally been very good and a high level of cooperation has continued due to mutual national interests. Thus, for Armenia, the

\footnotetext{
${ }^{485}$ Natalya Airapetova and Armen Saakyan, "Yeltsin and Ter-Petrosyan Sign Friendship Treaty: Document Opens New Stage of Strategic Partnership Between Moscow and Yerevan," Nezavisimaya Gazeta, 30 August 1997, p.3., in The Current Digest of the Post-Soviet Press, 1997, vol. XLIX, no. 35, p.16-17.

${ }^{486}$ Editors' Note, "Result of Pavel Grachev's Visit to the Transcaucasus: Minister at the 'Point of Return"” Kommersant, 25 March 1995, p.4, in The Current Digest of the Post-Soviet Press, 1995, vol.XLVII, no. 12, p. 22.
} 
Russian bases are at least some guarantee of internal security, as well as a pro-Russian position of officials in Yerevan. ${ }^{487}$

Moreover, Armenia was reliant upon Russia for weapons, fuel and other supplies of war. Russia supplied large amounts of military and economic assistance to Armenia. The degree of Russia's military support would not be disclosed until 1997. Lev Rokhlin, the Chairman of the Duma's Security Committee, discovered for the first time the amount of arms transfers from Russia to Armenia in the early 1990s. According to the Russian Minister of Defense, Igor Rodinov, the Russian Defense Ministry supplied Russian weapons to Armenia, such as several dozen tanks, long-range missiles and combat infantry vehicles worth 271 billion rubles, equal to 1 billion dollars. This development received an immense criticism and protest by the Azerbaijani government and there were even popular demands in Baku that Azerbaijan secede from the CIS. ${ }^{488}$ In addition, Armenia received all of the 366th Motor Rifle Regiments' equipment, plus air defense systems in Karabagh. These constituted a vital contribution to the Armenian victory in Karabagh.

Although Azerbaijan's reconciliation with Russia in the late 1990s has brought problems for Armenia, Russia has remained inclined towards Armenia in the Karabagh conflict. Aliyev tried to shift the Russian position. Azerbaijan re-joined the CIS and included a Russian oil company in the international consortium to exploit Azerbaijani oil in the Caspian sector. Azerbaijan's decision to join the CIS represents a plus for the CIS

\footnotetext{
${ }^{487}$ Pavel Felgengauer, "The Russian Army in the Transcaucasus," Sevodnya, 25 March 1995, p.1 in The Current Digest of the Post-Soviet Press, 19 April 1995, vol. XLVII, no. 12, pp. 25-26.

488 "The State Duma Has Exhausted the Question of Arms Supplies to Armenia,” Kommersant, 12 April 1997, p. 2, Armenian News Network, groong@ usc.edu, accessed by 12 April 1997.
} 
and therefore for Russian foreign policy in the 'near abroad'. Ter-Petrossian realized that Yeltsin's support of the principle of territorial integrity of Azerbaijan weakened Armenia's argument and position in the Karabagh issue.

Finally, Russia wanted to keep this region under its influence. As Russia gradually began to recover to formulate its long term policy toward the Caucasus, it grew increasingly concerned with the expansion of Western influence in the region. Even though Armenia was the most important ally in the region for Russia, Russia was aware that, due to its geopolitical as well as geoeconomic significance, Russia could not simply ignore Azerbaijan. Therefore, Russia preferred to utilize the inability of the Armenians and Azerbaijanis to find peace on the Karabagh problem so that Russia might retain its influence in the region.

\section{3d. Other Players}

\section{Turkey}

Armenia does not have good relations with Turkey. The main obstacle in the Turkey-Armenia relationship is the Armenian 'genocide' claim. The Turkish government argues that the Armenian population engaged in violent revolution during World War I. Anatolia and the surrounding regions were devastated by a cycle of war time violence which affected all sections of society. The Turkish government and historians insist that those who died did so as the result of a relocation policy, not from a preconceived 'genocide'. ${ }^{489}$ In this view, not only Armenians but also Ottoman Turks suffered as well; indeed, the latter suffered the heaviest losses in Anatolia.

\footnotetext{
${ }^{489}$ Dilaver A. Acar and Inan Ruma, "External Pressure and Turkish Discourse on 'Recognition of the Armenian 'genocide',," Southeast European and Black Sea Studies, September 2007, vol. 7, no. 3, p. 449.
} 
In the late 1980s and early 1990s both Armenia and Turkey made some efforts to establish a new and more constructive relationship. Turkey recognized the independence of Armenia together with those of Azerbaijan and Georgia. On coming to power in 1990, Ter-Petrossian opposed demands, mostly coming from the Armenian Diaspora, that recognition of the 'genocide' be placed at the top of the foreign policy agenda. The proposal of a new road from Armenia to the Turkish port of Trabzon was also discussed. ${ }^{490}$ Later, Armenia joined the Black Sea Cooperation Organization, and TerPetrossian went to the funeral of the late President of Turkey, Turgut Ozal.

The Karabagh conflict has strained relations between Armenia and Turkey. Turkey declined to establish diplomatic relations with Armenia unless Armenia accepts three conditions: The first is that Armenia should leave historians to decide on the 1915 events between Armenians and Turks, and Armenia should not support the Armenian Diaspora exploiting an historical issue for political gains. Second, the Armenian government should abandon support of all irredentist territorial claims on Turkey. As a final point, Armenian military forces should withdraw from all Azerbaijani regions and accept to solve the Karabagh problem peacefully. ${ }^{491}$

As the clashes intensified between Armenian and Azerbaijani forces on the border between Armenia and the Nakhichevan Autonomous region in the summer of 1992, Turkey moved some of its military forces to the Turkish-Armenian border. The reason is that Turkey is a guarantor of the autonomous status of Nakhichevan according to the Soviet-Turkish treaty of 1921. The war in Karabagh made it very difficult to improve

\footnotetext{
${ }^{490}$ Masih and Krikorian, 1999, p. 98.

${ }^{491}$ Gareth Winrow, Turkey and the Caucasus: Domestic Interests and Security Concerns, (London: The Royal Institute of International Affairs, 2000), p. 11.
} 
relations with Turkey between 1991 and 1994. Thus, the worsening of Armenia's relation with Turkey has been accompanied by ever-growing dependence on its alliance with Russia. $^{492}$

Ter-Petrossian hoped to improve relations with Turkey. He faced stiff resistance among Armenian political elites and in surmounting Armenian historical enmity for Turks and distrust of Ankara's motives. Ter-Petrossian's diplomatic initiative caused powerful reactions among Armenian and Turkish political elites. Turkish leaders have recognized the constraints they face in the Armenian-Azerbaijani conflict.

The Azerbaijani closing of a pipeline supplying 80 percent of Armenia's gas has forced Erevan into precarious dependence on a single pipeline running through an Azerbaijani-populated region of Georgia which had been routinely sabotaged. Armenian discussions with Turkey had yielded limited results. Turkey briefly allowed shipments of western relief aid to cross Turkish territory into Armenia under the pressure of some Western countries but this led to an increase of tension between Azerbaijan and Turkey, especially between May 1992 and early $1993 .{ }^{493}$

After the Armenian offensive, Demirel stated that air and land transportation links with Armenia were closed and he called on the permanent members of the Security Council of the United Nations to take active measures to stop the Armenian offensive and the occupation of Karabagh. ${ }^{494}$ When Azerbaijani leaders called for Turkish intervention to respond to the Armenian offensives in April 1993, Demirel expressed sympathy, but

\footnotetext{
${ }^{492}$ Winrow, 2000, pp. 11-12.

${ }^{493}$ De Waal, 2003, p. 213.

${ }^{494}$ Büşra B. Ersanll, "The First Years of Independence: Azerbaijan, Kazakhstan, Kyrgyzstan, Uzbekistan, Turkmenistan,” TBMM Tutanak Dergisi, 1993, vol. 34, p. 215; and Milliyet, 22 April 1993.
} 
briefly explained his cautious policy by arguing that there was no legal basis for a Turkish intervention. He said that such intervention "would solve nothing," as it would only convince other states to similarly aid Armenia. ${ }^{495}$

Despite the absence of diplomatic relations between Armenia and Turkey, prospects for some serious Armenian-Turkish economic cooperation had become possible during the second half of the 1990s. A stable cease-fire in Karabagh and rather active trade relations of Armenia with Iran had prevented the Turkish-Azerbaijani blockade from succeeding. In addition, the pragmatic approach of the Ter-Petrossian government to demonstrate its readiness for fully normalized bilateral relations created a positive atmosphere between these countries. A large delegation of the Union of industrialists and entrepreneurs of Armenia headed by Armenian President's brother, Telman Ter-Petrossian, visited Turkey. Telman Ter-Petrossian expressed that economic relations and cooperation might begin even before diplomatic relations were established. Deputy Foreign Minister of Armenia Vartan Oskanian believed that "such visits of representatives of business and industrial circles may lay grounds for political and diplomatic relations. ${ }^{, 496}$ Finally, the early expectations of a rapid Turkish-Armenian rapprochement could not produce a final result. But the tension between Turkey and Armenia did not turn into a hot conflict. Instead, because of the United States' efforts to encourage better Turkish-Armenian relations, both sides have kept channels of communication open. $^{497}$

\footnotetext{
${ }^{495}$ FBIS-WEU, 10 March 1992, quoting Turkiye Radyolari, 9 March 1992.

${ }^{496}$ Armen Khanbayan, "Opening of the Border with Turkey is Beneficial for Both Sides," Nezavisimaya Gazeta, 20 August 1996, no. 153, Armenian News Network, accessed 20 August 1996.

${ }^{497}$ Hunter, 1994, p.47.
} 


\section{The United States}

Relations between Armenia and the United States date to the earthquake that happened in Armenia in 1988, when the United States mobilized the United States Agency for International Development (USAID) to support relief operations and supply aid for the victims of the earthquake. This was the first direct aid from the United States to one of the Soviet Union republics. One of the reasons was a strong ethnic lobby of Armenian Diaspora. Even before Armenia became independent, the Diaspora community was actively involved in Armenian politics and relations between Armenia and the United States. The Armenian Diaspora in the United States had a significant impact on the U.S. policy towards Armenia and Armenian cause. For instance, the Armenian lobby successfully lobbied to prevent the direct delivery of United States aid, including humanitarian relief, to the government of Azerbaijan. Although the Armenian army occupied the land of Azerbaijan, the United States Congress, against the opposition of both the Bush and Clinton administrations, passed Section 907 of the Freedom Support Act aiding Armenia; likewise, becuase Azerbaijan blockaded Armenia economically, the Congress accused Azerbaijan of being the aggressor in the Karabagh conflict. ${ }^{498}$ Therefore, it is clear that the Armenian Diaspora and the United States Congress were the most important actors to define the Armenian-United States relations in the early 1990s.

While the Armenian government valued the contribution of the Diaspora to Armenian relations with the United States, it also recognized the limiting role of the Diaspora on Armenian relations with neighboring countries, especially with Turkey. The Diaspora political organizations, such as the nationalist ARF, created political problems

\footnotetext{
${ }^{498}$ Freedom for Russian and Emerging Eurasian Democracies and Open Markets Support Act of 1992, Public Law 102-511, sec. 907, 24 October 1992.
} 
both internally and externally. Internally, when the ARF lost the elections, it became an aggressive nationalist opposition party to challenge the Armenian leadership. Externally, the ARF and the other Diaspora-originated parties pushed the Armenian government to make the controversial issue of the 'genocide' one of the central pillars of Armenian foreign policy.

The Ter-Petrossian government desired to become part of the international economical and political system. He understood that the only way to reach his goal was to develop close relations with Turkey because the only way to link Armenia with the Western world passed through Turkey. He also realized that the United States and Turkey's interests in the Caucasus are parallel. The United States supports Turkey to become a model for the Caucasus and Central Asian states. There are two reasons for this: first, the collapse of the Soviet Union created a security vacuum in the region and second, Iran tried to export its political system to these regions. Therefore, the United States was concerned about the expansion of Iranian influence in the region. In order to prevent Iranian activities the United States supported Turkey to play a significant role.

After the signing of the "deal of the century" in late 1994, the interests and attention of the policy-making elites in the United States began to increase in the Caucasus region. In other words, oil has played a role to increase the American interest in the region. Oil companies have also unsuccessfully lobbied to overcome the Armenian lobby's support for Section 907 of the Freedom Support Act, which places restrictions on American aid to the Azerbaijani government. ${ }^{499}$

\footnotetext{
${ }^{499}$ Edward W. Walker, “Armenia's Constitutional Coup and the Karabakh Conflict,” Analysis of Current Events, March/April 1998, vol. 10, no. 3-4, http://socrates.berkeley.edu/ bsp/caucasus/articles.html. The section of 907 restricted all the governmental aid Azerbaijan, including humanitarian ones.
} 
In the second half of the 1990s in the United States public opinion on Armenia and the Armenian issues started to shift. For example, the Washington Post published an editorial on March 1, 1997, questioning the wisdom of continuing to give aid to Armenia so generously at a time when it had derailed its democracy. ${ }^{500}$ This was the fourth editorial critical of Armenia published by the Washington Post between 1995 and 1997. Armenia received another criticism when National Public Radio broadcasted a lengthy report on April 71997 describing the country's economic and political situation. The third example of criticism of Armenia was an editorial published in the 10 April 1997 issue of The Wall Street Journal accusing Russia of providing to Yerevan enough military "hardware to destroy Baku and nearby oil fields."

Following the meeting with Ter-Petrossian, the United States Energy Secretary, Federico Pena said: "Our task is to promote safe shipment of oil to the world markets, stimulate financial growth in countries of the region, speed up the creation of the Eurasian corridor for transportation of the Caspian and Central Asian oil and gas to the world markets, while defending the United States economic interests. Armenia's joining this process is viewed by us as a factor of stability and prosperity of the entire region." Pena's visit to Armenia was mostly aimed at finding out the Armenian leadership's standpoint regarding the possibility of installation of the main Caspian oil pipeline via Armenia. ${ }^{502}$

\footnotetext{
${ }^{500}$ Editorial, “Aid to Armenia,” The Washington Post, 1 March 1997, p. A22.

${ }^{501}$ Harut Sassounian, "How Long Can Armenia Continue Ignoring Negative Publicity?” California Courier Publisher, 15 April 1997, Armenian News Network, groong@osc.edu, accessed by 15 April 1997.

${ }^{502}$ David Petrosyan, “Will Azerbaijan-Turkey Oil Pipeline Traverse Armenia?," Review \& Outlook, Armenian News Network, groong@usc.edu, accessed 18 November 1997.
} 
Ter-Petrossian and Pena seemed to agree on the installation of the 'mainstream' oil pipeline via Armenia during Pena's visit to Armenia. A decision on the final route of the 'mainstream' oil pipeline was supposed to be taken at the end of 1997. Thus, the date of adoption of a final resolution for the Caspian pipeline route on that matter had been deliberately put off for a year to allow a final agreement regarding the settlement of the Karabagh conflict to be achieved by that time. ${ }^{503}$

Another development of the second half of the 1990s is that the United States took an active role in the Karabagh negotiations. Since 1994, the United States has been pushing Armenia and Azerbaijan to agree to a resolution while at the same time working on the decision how to transport the Azerbaijani oil. The Ter-Petrossian government considered the American interest in the Karabagh problem and the possibility of the pipeline passing through Armenia as an opportunity for Armenia to link to the international political and economic system and to decrease the Armenian dependency on Russia. However, the Kocharian government rejected the idea to link the Karabagh problem with the pipeline issue. Kocharian believed that the Armenian Diaspora is representative of the Armenian interests in the United States. In conclusion, ArmenianUnited States relations are shaped by two important factors: the role of the Armenian Diaspora and its lobby, and the American oil corporations' investments in Azerbaijan.

\footnotetext{
503 "The U.S. Role in the Caucasus and Central Asia," Congressional Hearing Before the Committee On International Relations, House of Representatives, 105 Congress, Second Session, 30 April 1998, p. 20.
} 


\section{3e. Conclusion}

Comparing Azerbaijan and Georgia, Armenia had relatively stronger state in the early 1990s. There were internal cohesion and no real internal threat to the Armenian leadership. For the Armenian political elite, the main threat was external one and coming from its neighbors, Azerbaijan and Turkey. Therefore, the foreign policy of Armenia was shaped by its relations with neighboring countries, especially Russia, Azerbaijan and Turkey. The deterioration of the internal situation in Georgia and Armenia's hostile relations with Azerbaijan and Turkey in the early 1990s created a geopolitical isolation around Armenia. Thus, Armenia's isolation made the external threat the primary challenge to Armenian's foreign policy. Armenia regarded Azerbaijan and Turkey as the main threats. This created dangerous tension between on the one hand Armenia, and Azerbaijan and Turkey on the other, thus, Armenia remained dependent on the flow of military and nonmilitary assistance from Russia. Under these conditions, the Armenian government saw Russia as a protector, and Turkey and Azerbaijan as enemies. Meanwhile, Russia saw Armenia as its closest ally in the Caucasus. Therefore, by bandwagoning with Russia, Armenia reduced any possible aggressive intentions of Russia and secured the benefits of Russian support for Armenian relations vis-à-vis other states. As a result, the Armenian President, Ter-Petrossian accepted almost all Russian terms such as having the Russian military bases and border guards in 1993 and 1994. Thus, he believed that it required bandwagoning with Russia to become member of the CIS in order to protect itself from real threats by Azerbaijan and a potential threat from Turkey. 
Moreover, because of his success in Karabagh, the Karabagh conflict became the first and most important source of legitimacy for the Ter-Petrossian leadership. All spectrums of the Armenian political elites, such as nationalist and communist elites, as well as the diaspora, supported his leadership and his foreign policy objectives. TerPetrossian's early foreign policy, therefore, was based on coordinating policy with Russia, which provided material support for the Karabagh war, as well as securing full support of the Armenian political elites both in and out of the country.

Meanwhile, because of the embargo levied by Azerbaijan and Turkey, the Armenian government experienced severe economic difficulties. The blockade of Azerbaijan and Turkey caused serious economic problems for Armenia and led to a sharp economic and energy crisis in the country. Ter-Petrossian understood that he might lose power because of the economic crisis. He also believed that Armenia could not deal with its economy crisis as long as it was cut off from vital transport routes and supplies. As a result, Ter-Petrossian's concentration shifted from the Karabagh problem to the Armenian economic and domestic crises.

In the middle of the 1990s, Ter-Petrossian realized that he had to consider not only the position of the Armenian political elite and leadership of Karabagh but also the preferences of the international community, especially the United States, Turkey and other major western powers. He explored alternative foreign policies for Armenia, such as decreasing Armenia's strategic direction from total dependence on Russia and looking for a way toward reconciliation with Turkey. Ter-Petrossian believed that the only way to decrease Armenian isolation was to connect to the Western world through Turkey. For 
this reason, Ter-Petrossian's government tried to establish normal relations with Turkey in the middle of the 1990s.

Ter-Petrossian also understood the Karabagh issue is an obstacle and should be resolved; otherwise Armenia would lose an opportunity to benefit from the Caspian oil deals and remain an isolated country in the region. Armenia needs Turkey to open up its border and allow transportation pass to through Turkey to Armenia. Ter-Petrossian had feared that Azerbaijan's natural resources, oil and gas provided leverage to Azerbaijan to improve its economic and military capacity to prepare another war against Armenia. ${ }^{504}$ However, Ter-Petrossian's foreign policy shifts alienated him from both the nationalist political elites and the diaspora. Ter-Petrossian was pushed to resign by nationalist elements in his inner political circles, led by his prime minister, Robert Kocharian. Therefore, the Karabagh issue became a litmus test for the Armenian political system. Kocharian, a nationalist from Karabagh, became the president of Armenia in 1998. The Armenian position on Karabagh became firm and Russia now became Armenia's only strategical partner. The Kocharian government rejected the OSCE Minsk Group's peace plan. Therefore, under his leadership, Armenian foreign policy was driven by more nationalist tones. In this circumstance, the parameters of Armenian foreign policy decreased as Armenian foreign policy became a hostage to the Karabagh issue. Thus, Armenia's most important foreign relationship was with Russia, primarily due to the Russian security umbrella against potential external threats. Armenian leaders established a strategic partnership with Russia to ease pressure because of Turkey on the western border and Azerbaijan on the southern and eastern border.

\footnotetext{
${ }^{504}$ Masih and Krikorian, 1999, p. 111; and Croissant, 1998, pp. 131-132.
} 
However, the expansion of Armenian-Russian relations, while enhancing Armenian security, limited Armenia to develop alternative foreign policies in the region. It made Armenia become totally dependent on Russia. Moreover, for Russia, Azerbaijan and Georgia are more important than Armenia. Azerbaijan and Georgia have borders with Russia. Azerbaijan has rich oil and gas reserves. In addition, Azerbaijan and Georgia are very important transit countries between Russia and Turkey, and Russia and Iran respectively. Therefore, these are significant challenges for the Russian alliance with Armenia, given th enormous asymmetry in favor of the Russian side. ${ }^{505}$

Consequently, Armenia's relations with Moscow have traditionally been very good and a high level of cooperation has continued due to mutual national interests. Thus, for Armenia, the Russian bases were also guarantee of internal security, and the proRussian position of leadership in Armenia. For Armenia, Russian military forces in Armenia were only reliable guarantees not only against external threats to the Armenian state, but also against internal threats to the regime. This demonstrates the complex level of Russian-Armenian relations during 1990s.

While it is obvious that Armenia is completely dependent on the flow of military and nonmilitary supplies from Russia and aid from the Armenian diaspora, the way the Armenian government has mobilized its limited resources has also played an important role. ${ }^{506}$ In other words, the combination of Russian and Diaspora Armenian financial and material aid to the country has positively affected Armenia's national security. In addition to these, the country's political stability, the relatively smooth management of

\footnotetext{
${ }^{505}$ Masih and Krikorian, 1999, pp. 95-96.

${ }^{506}$ Aves, 1995, p. 223.
} 
civil-military relations, and an ability to mobilize its resources effectively were indicators of Armenia's comparative success relatively to the other Caucasus states.

Therefore, Russian-Armenian relations developed based on their mutual interests. Armenia saw Russia as its only ally against the potential threats of Turkey and Azerbaijan. Russia saw Armenia as the most reliable partner in the region. For this reason, Armenian foreign policy orientation has not changed substantially on the last seventeen years under the different presidents. Having relatively internal stability and cohesion, Armenia bandwagoned with Russia to respond potential threats coming from its neighboring countries, Azerbaijan and Turkey, except shortly in the middle of the 1990s.

\section{Azerbaijan}

\section{4a. The Foreign Policy-Making Process}

Azerbaijan's foreign policy has been shaped by the strong political orientations of its first two leaders, in the case of Mutalibov, a strong pro-Russian orientation, and in the case of Elchibey, a strong pro-Turkish, pro-nationalist orientation in the early 1990s. Aliyev's foreign policy was pragmatic and based on both personal and national interests.

Azerbaijan enjoys some advantages compared with Armenia and Georgia in seeking to accomplish its national interests through foreign policy. First, its significant reserves of oil have attracted international interest to the country. Second, its cultural and ethnic ties to Turkey have allowed Azerbaijan to balance Russia with another regional power. Moreover, Azerbaijan was the only CIS member that had no Russian forces on its soil during the 1990s. It resisted Russian pressure to establish military bases, conduct 
joint naval patrolling of the Azerbaijani sector of the Caspian Sea, and joint control of the borders with Iran and Turkey and the corresponding airspace.

However, Azerbaijan has some disadvantages too. In Azerbaijan political developments have been just as turbulent as in Georgia. While Azerbaijan has substantial oil wealth and access to the international market through its closes ties with Turkey, the war with Armenia made the country politically unstable and left twenty percent of the country’s territory under Armenian occupation. Azerbaijan also suffered a sudden economic decline and clashes between political elites in the early 1990s.

The institutional weakness of the Azerbaijani state was related to the instability of the political system, and in particular internecine conflicts between political elites and their outcomes. Azerbaijanis elected four presidents and endured considerable domestic political turmoil in addition to the war with Armenia in its first three years of independence. For example, Mutalibov and Mamedov stayed in power a few months, while Elchibey barely completed his first year. Only Aliyev consolidated his power and established authoritarian but stable conditions in Azerbaijan. Thus, Azerbaijani domestic politics was more chaotic than that of Armenia. This turbulent condition not only posed threats to the leaderships but also shaped Azerbaijani foreign policy orientation and its policy choices.

Azerbaijan also inherited from the Soviet Union a chaotic bureaucracy and "clientist" mentality. The bureaucratic and political networks that developed in the Soviet era lived on in post-Soviet Azerbaijan. These networks continued to exercise significant 
influence on the development of the Azerbaijani state by promoting fierce, bureaucratic infighting and power struggles within the state. ${ }^{507}$

Azerbaijan's foreign policy during the early 1990s had been affected not only by internal factors but also by its external geopolitical setting. Azerbaijan is also of interest to outside actors, most notably Turkey and the West, because of ethnic kinship and its vast oil and gas reserves. Moreover, Russian policies have been especially important. The manipulation of Azerbaijan's internal divisions by competing power centers in Moscow intensified domestic conflict in Azerbaijan, worsening the Karabagh problem and contributing to the chronic instability of Azerbaijani domestic politics. These external actors have tried to influence Azerbaijan's internal political developments and its foreign policy choices in directions more compatible with their own interests. Thus, the combination of these factors has made the state-building and foreign policy processes extremely difficult in Azerbaijan. ${ }^{508}$

The four state institutions involved in the foreign policy process in Azerbaijan are: The President's office, the Ministry of Foreign Affairs, the State Oil Company of Azerbaijan (SOCAR), and Parliament. Azerbaijan is governed by a presidential system, and the Ministry of Foreign Affairs and SOCAR are a part of the executive branch. SOCAR played a significant role during the 1990s as a result of the negotiations between the Azerbaijani state and major international oil corporations. The chairman of SOCAR carries the rank of minister. That means that Azerbaijan's foreign policy is formulated

\footnotetext{
${ }^{507}$ Shirin Hunter, "Azerbaijan: Searching for New Neighbors," in New States, New Politics: Building the Post-Soviet Nations, Ian Bremmer and Ray Taras, eds., (Cambridge: Cambridge University Press, 1997), p. 440.

${ }^{508}$ Hunter, 1997, p. 440.
} 
exclusively by the president and his close advisors. The Azerbaijani Parliament is rarely involved in foreign policy-making process and plays the role of rubber-stamp. ${ }^{509}$

Azerbaijan had problems with establishing a Ministry of Foreign Affairs. These problems included creating departments within the ministry, recruiting and training diplomats, and establishing and staffing embassies abroad. Because of the complexity of these tasks, few embassies were established during the first year of independence. Full diplomatic relations, including mutual exchanges of missions, were first established with Turkey, the United States, and Iran. For this reason, the first groups of Azerbaijani ambassadors came from different professions: for instance, Hafez Pashayev, the first Azerbaijani Ambassador to the United States from 1993 to 2004, is a physicist.

When Mutalibov was the president of Azerbaijan, he shared foreign policy authority with the Prime Minister Hasan Hasanov. Mutalibov concentrated on Azerbaijan-Russian relations. While Hasanov dealt with Azerbaijani relations with Turkey and Iran. ${ }^{510}$ Mutalibov had the last word for important foreign policy decisions. Under the Elchibey regime, Elchibey shared his decision-making authority with his close associates, such as Isa Gambar, chairman of the Majlis; Tofiq Kasymov, foreign minister; Rahim Qaziyev, defense minister; and Iskendar Hamidov, interior minister. ${ }^{511}$

\footnotetext{
${ }^{509}$ David I. Hoffman, “Azerbaijan: The Politicization of Oil," in Energy and Conflict in Central Asia and the Caucasus, Robert Ebel and Rajan Menon, eds., (Lanham: Rowman \& Littlefield Publishers, Inc., 2000), p. 62 .

${ }^{510}$ Hasanov is an interesting character in the Azerbaijani politics. He was a secretary of Azerbaijani Communist Party in late 1980s, prime minister in Mutalibov era, in 1990-1992, ambassador to United Nations in Elchibey era in 1992-1993, and foreign minister in 1993-1998 under Aliyev's presidency. Interestingly, when Mutalibov resigned and the APF leadership wanted Hasanov, who had been important position in Azerbaijan Communist Party, to replace Mutalibov. See, Elizabeth Fuller, "Azerbaijan after the Presidential Elections," RFE/RL Research Report, 26 June 1992, pp. 1-3.

${ }^{511}$ Goltz, 1998, pp. 203-204.
} 
After Aliyev came to power, he was first forced to share power with prime minister Huseyinov, chairman of Parliament Rasul Guliyev and foreign minister Hasan Hasanov but he removed them one by one in the second half of the 1990s and came entirely to dominate the political scene, with no minister or pro-government parliamentarian having a strong independent political profile or power base. ${ }^{512}$ Aliyev controlled all state activities and policies. He was the ultimate decision-maker. The ministers played no real role in the foreign policy-making process. Aliyev revived not only the old Soviet methods of governance but also the old systems of clan alliances and patronage; for instance, the Nakhichevan regional clan became very active in his time. ${ }^{513}$ Aliyev mainly conducted relations with Russia and the United States himself. Economic relations with international financial institutions and foreign countries were handled by the prime minister. The foreign minister was most active in conducting relations with other states and international organizations. When Vafa Guluzade was the president's senior adviser for foreign policy, he represented Azerbaijan at the CSCE/OSCE negotiations for a resolution of the Karabagh conflict. ${ }^{514} \mathrm{He}$ also had a prominent role in conveying the president's important messages, especially to Armenia

\footnotetext{
${ }^{512}$ Herzig, 1999, p. 27.

${ }^{513}$ Arif Yunusov, "The Southern Caucasus: Cooperation or Conflict?" in Building Security in Europe's New Borderlands: Subregional Cooperation in the Wider Europe, Renata Dwan, ed., (Armonk: M.E. Sharpe, 1999), p. 151.

${ }^{514}$ Vafa Guluzade also worked under Mutalibov and Elchibey. He was a senior of foreign policy advisor of three presidents from 1990 to 1998. Guluzade and Foreign Minister of Azerbaijan, Tofiq Zulfigarov resigned over differences of the Karabagh issue with the president. See, Elmira Amrahgizi and Betty Blair, "Diplomatic Interview Vafa Guluzade: Foreign Policy Advisor to Azerbaijan's President," Azerbaijan International, Spring 1997, vol. 5, no. 1, pp. 39-43.
} 
and Turkey. The Chairman of SOCAR, Natiq Aliyev and Valekh Aleskerov led the Azerbaijani team to negotiate an agreement with international oil corporations. ${ }^{515}$

Several organizations and political groups exercised significant influence in the Azerbaijani politics. One of the most important of them is the Azerbaijan Popular Front (APF-Azerbaycan Halk Cephesi). The AFP was established and grew strong during the conflict over Karabagh at the end of the 1980s. In early 1990 the Karabagh conflict turned from guerrilla warfare between Armenian and Azerbaijani paramilitary groups into a real war with tanks and heavy artillery. Therefore, the Karabagh issue became a platform for both Azerbaijani ruling elites and opposition groups to struggle for power in the country. For example, as early as 1989 the APF became a real threat to the Communist leadership in Azerbaijan. The Azerbaijani Communist leadership responded quickly and placed Baku under martial law. ${ }^{516}$ Azerbaijani Communist Party (ACP) Secretary Ayaz Mutalibov cracked down hard on the APF and its members. Thus, the Karabagh issue became the litmus test for the Azerbaijani leadership.

Opposition groups and parties, such as APF, using the Karabagh issue to mobilize people and organizing big demonstrations, had at different times posed challenges to the Communist leadership in the early 1990s. As the first president of independent Azerbaijan, Mutalibov had a strong connection with both Soviet nomenklatura elites and the new Russian leadership. His foreign policy was totally oriented to Russia. He supported the Moscow coup in 1991 and favored signing the CIS founding documents. ${ }^{517}$

\footnotetext{
${ }^{515}$ LeVine, 2007, pp. 193-196.

${ }^{516}$ Olcott, Summer 1995, p. 355.

${ }^{517}$ Hunter, 1994, p. 59 and p. 71.
} 
However, in spring 1992, when APF dominated the legislature and Azerbaijanis elected the nationalist Abulfaz Elchibey, the Azerbaijani parliament refused to ratify the CIS founding documents. The Elchibey government attempted to stay out of the CIS. ${ }^{518}$ Elchibey was elected on a platform of strengthening Azerbaijan's position in Karabagh to triumph in the war but he failed and Azerbaijan lost more of its territory. The reason was not only because Azerbaijan did not have a regular army but also because bureaucratic corruption, local loyalties and the anti-Elchibey sentiments of various groups produced the result.

Elchibey has been seen as a nationalist and pro-Turkish president. Elchibey's departure from the political scene and his replacement by Haydar Aliyev, former Soviet Politburo member and Azerbaijan Communist Party Secretary, indicated that there would be a substantial shift of Azerbaijani's foreign policy towards Russia. In fact, the first two years of the Aliyev administration could be considered as pro-Russian based on his policies. Aliyev took back Azerbaijan into the CIS in October 1993 and the Russian oil company Lukoil was brought into the Azerbaijani consortium, being granted rights to exploit Azerbaijani oil. Finally, Russian successfully mediated a ceasefire between Armenian and Azerbaijani forces over Karabagh in $1994 .{ }^{519}$

Aliyev realized that his pro-Russian decision could not produce a decisive result for the Karabagh conflict. As a former Soviet politburo member, he was aware of all possible political maneuvers in Moscow and the relative weakness of Russia in the

\footnotetext{
${ }^{518}$ Audrey L. Altstadt, "Azerbaijan's Struggle Toward Democracy,” in Conflict, Cleavage, and Change in Central Asia and the Caucasus, Karen Dawisha and Bruce Parrott, eds., (Cambridge: Cambridge University Press, 1997), p. 135.

${ }^{519}$ Waal, 2003, p. 226 and pp. 253-254.
} 
international system. Therefore, after securing his position as the leader of the country, Aliyev began to refuse to accept Russian demands. While he was noticeably more pragmatic than the previous Azerbaijani leaders in dealing with Russia, Aliyev sought to balance Russian influence by strengthening his internal as well as external position by increasing his relations with other major powers. For example, as Russian pressure escalated in 1994, he visited Turkey to refurbish good relations and secure diplomatic support.He signed important agreements with the Turkish government, such as training Azerbaijani cadets in Turkey. ${ }^{520}$

The Karabagh issue is one of the most important and significant foreign policy issues of the different Azerbaijani governments. It is not only an indicator for Azerbaijani foreign policy but also a platform for a bid for power in the country. For instance, the first three presidents of Azerbaijan started their presidency with attempts to make military progress in Karabagh. The first two of them (Mutalibov and Elchibey) lost their presidential positions. The third, Aliyev, accepted a cease-fire.

The Karabagh issue can be divided into four phases in 1990s: the first beginning in fall 1987, the second in spring 1992, the third in spring 1994 and the fourth in fall 1996.

The first was the beginning of pro-Karabagh demonstrations in Karabagh, Erevan and Baku, and escalation of the conflict. There was a rapid escalation of fighting immediately after the demonstrations. As this was the period when the APF was seen to be more vocal than the Azerbaijani Communist Party and was gaining momentum among

\footnotetext{
${ }^{520}$ Olcott, 1995, pp. 355-356.
} 
Azerbaijani public and political elites, Soviet leaders in Moscow believed that APF would seize power in Azerbaijan. ${ }^{521}$

The second phase of the conflict had two important outcomes. First, the fate of leaders in Azerbaijan began to be decided more or less locally rather than in Moscow and the issue of Karabagh became the most important factor for their success or failure. For example, Ayaz Mutalibov, who resisted the formation of a national army, was ousted in the wake of the massacre of Azerbaijani refugees fleeing Kelbajar. In June 1993, when President Abulfaz Elchibey was ousted, one of the reasons given was his failure to win the Karabagh war. Second, a military solution to the problem became the policy preferred by both Armenian and Azerbaijani sides, which exposed them to manipulation by Russia, the sole supplier of weapons to both sides. The military solution was disastrous for the Azerbaijani military, which consisted of unorganized and uncoordinated Azerbaijani battalions run by warlords. On the other hand, Armenian military forces were wellorganized and coordinated as well as well-supplied with Russian weapons. ${ }^{522}$

The third phase in Karabagh began in spring 1994 with a declaration of a ceasefire by both sides. Between 1988 and 1994, the Karabagh conflict had been the focus of mediation by a variety of international actors, including Russia, Turkey, Iran, Kazakhstan, and Western countries and international organizations. For example, the OSCE Minsk Group was set up in January 1992 as the main international channel for resolution of the Karabagh conflict. In May 1994 Russia succeeded in mediating the final

\footnotetext{
${ }^{521}$ Michael Dobbs, "Soviets Say Troops to Plan Seizure of Power," The Washington Post, 27 January 1990, p. A13.

${ }^{522}$ Svante E. Cornell, "Undeclared War: The Nagorno-Karabakh Conflict Reconsidered," Journal of South Asian and Middle East Studies, Summer 1997, vol. 20, no. 4, pp. 8-9.
} 
cease-fire that left Armenian forces in control of 20 percent of Azerbaijani territory. The Armenian forces held most of Karabagh, with the exception of eastern parts of Martuni and Mardakert districts and the entire Shahumian district in the north. In addition, the Armenia army occupied the Kelbajar, Lachin, Qubatli, Zangelan, and Jebrail districts as well as parts of the Fizuli and Aghdam districts. Thus, the Armenian forces created a 'Golan Heights' style demilitarized zone around Shusha in Karabagh. ${ }^{523}$

In the fourth phase in the conflict, the Minsk Group co-chairs (Russia, the United States and France) at the OSCE Lisbon Summit in December 1996 offered an agenda for settling of the Karabagh conflict based on the territorial integrity of Azerbaijan and providing for the "highest degree" of autonomy for the Karabagh Armenians within Azerbaijan. $^{524}$

Another most important and significant factor of Azerbaijani foreign policy concerns Azerbaijan’s hydrocarbon reserves. As an essential factor in Azerbaijan’s relations to the outside world, Azerbaijan's hydrocarbon reserves attracted foreign investors even before the Middle East reserves become a prominent source of competition between major powers in the early 1900s. Nobel, Rothschild, the Rockefeller families, BP, Standard Oil, and Shell giant are competed with each other. ${ }^{525}$ Therefore,

\footnotetext{
${ }^{523}$ Cornell, 2001, pp. 96-97. See also Caroline Cox, "Nagorno-Karabakh: Forgotten People in a Forgotten War," Contemporary Review, January 1997, vol. 270, no. 1572, p.11.

${ }^{524}$ John J. Maresca, "U.S. Ban on Aid to Azerbaijan (Section 907): How It Started in 1992 and Why It Should be Lifted," Azerbaijan International, Winter 1998, vol.6, no. 4, pp. 54-55. The Armenians vetoed the proposal and it was read as the "Chairman-in-Office" statement. Another proposal is Goble plan. Paul Goble has proposed a plan to resolve the Karabagh problem. In exchange for Karabagh, Armenia will yield Zangezur, the southern region of Armenia bordering on Iran, to Azerbaijan. Thus Azerbaijan would get directly connected with Turkey through Zangezur and Nackhichevan. See, Paul Goble, "Coping with the Nagorno-Karabagh Crisis," The Fletcher Forum of World Affairs, Summer 1992, vol. 16, no. 2, p. 26.

${ }^{525}$ See, LeVine, 2007, Chapter 1 and 2.
} 
the oil industry also turned out to be the most important instrument for Azerbaijan to attract international attention after Azerbaijan's independence.

After independence, the Azerbaijan State Oil Company (SOCAR) had negotiated with Western oil companies on a major project for tapping offshore oil deposits. The project was conceived under Mutalibov and advanced Elchibey. His plan was that Western companies would extract the oil and provide security and support to Azerbaijan. Interestingly, a week before the contract was signed by Elchibey in London with Western and Turkish oil companies, the local warlord, Suret Huseyinov from Gandja city, which had a Russian military garrison, took possession of the weapons and provisions of the Russian army, which withdrew. Days later, Huseyinov mounted a successful coup against Elchibey. ${ }^{526}$

Aliyev now became the president of the country and Huseyinov prime minister. The new Azerbaijani leadership canceled the contract. After Aliyev ousted Huseyinov from his position and secured his own leadership, he concluded a new deal with Western, Russian and Turkish oil companies. In September 1994, Azerbaijan's state oil company SOCAR and a consortium of foreign oil companies called the Azerbaijan International Operating Company (AIOC) signed a $\$ 7.5$ billion agreement to exploit two offshore oilfields called the "Contract of the Century." ${ }^{, 527}$ Thus, pressure from Moscow succeeded

\footnotetext{
${ }^{526}$ See, Sabit Bagirov, “Azerbaijan's Strategic Choice in the Caspian Region,” in The Security of the Caspian Sea Region, Gennady Chufrin, ed., (Oxford: Oxford University Press, 2001), pp. 180-181. Russian oil companies were excluded for the contract.

${ }^{527}$ The deal was concluded with an enlarged consortium of foreign companies-four American (Amoco, Unocal, Pennzoil, McDermott), one British (British Petroleum), Norwegian (Statoil), Turkish (TPAO), a Saudi Arabian, and Russian (Lukoil). The contract entailed the development of three offshore fields Chirag, Azeri and Gunesli with $\$ 7.5$ billion dollar foreign investment over the course of 30 years. See, Rosemarie Forsythe, The Politics of Oil in the Caucasus and Central Asia, Adelphi Paper, Paper 300, (Oxford: Oxford University Press, 1996), pp. 40-41, and also Bagirov, 2001, p. 181.
} 
in inserting the Russian oil company, Lukoil into the new international consortium and a new contract. Lukoil was offered a 10\% stake in the Azerbaijani oil consortium by the Azerbaijani government. ${ }^{528}$

The Azerbaijani government and members of the international consortium then faced the problem of how to transport the oil and how to either secure access to the existing pipelines or find routes for the construction of new pipelines. In other words, in the case of the Azerbaijan oilfields, two decisions had to be made: first, how to transport the "early oil" from the region, and second how to transport the bulk of the oil in the long-term. From the very beginning Elchibey entertained the idea of laying a pipeline across Turkey to the world market. ${ }^{529}$ When Aliyev came to power, however, he demanded a new look at the terms of the contract as well as pipeline options.

The AIOC and Aliyev compared the Turkish and Russian options with the other international options. Initially Aliyev and Yeltsin agreed that a Russian route via Chechnya would be the main pipeline. Soon, however, the agreement on the Russian route via Grozny became threatened owing to the fact that the situation in Chechnya did not stabilize and war between Russian military forces and Chechen guerrillas continued until the end of 1996. Moreover, despite the preliminary agreement under which "early" oil from the Caspian Sea offshore was supposed to begin to flow along the Baku-GroznyNovorossiysk route as early as 1998, during Aliyev's visit to Turkey in 1997 he began to talk about the possibilities of having the Turkish option as an alternative route to the

\footnotetext{
${ }^{528}$ It must be noted that inserting Lukoil to the consortium was the success of Russian Oil Ministry. The Russian Foreign Ministry protested Lukoil's signature of the "Contract of the Century" with Azerbaijan at a time when it was still pressing Moscow's case for the Caspian to be recognized as a condominium and rejecting Azerbaijan's claims to the Sea's resources. See, Bagirov, 2001, p. 186.

${ }^{529}$ Philip Robins, Suits and Uniforms: Turkish Foreign Policy Since the Cold War, (London: Hurst \& Company, 2003), p. 304.
} 
Russian option. To this effect, he made a statement that Azerbaijan preferred the Turkish option for transporting oil over the Russian one. ${ }^{530}$

Armenia's victory in Karabagh, combined with the ineffectiveness of the international mediation attempt without Russia and Russia's military involvement in Huseyinov's June 1994 coup all emphasized Russia's importance not only in the region but also Azerbaijani internal politics during the first half of 1990s. ${ }^{531}$ Although Azerbaijan joined the CIS Collective Security Treaty, signed in Tashkent in 1992, and leased the Gabala radar station from Russia, it was the only CIS country in which there were officially no Russian troops. ${ }^{532}$

In the second half of the 1990s, Azerbaijani relations with Western countries and companies improved. Azerbaijan had done its utmost to forge ties with Turkey and the United States, including the offer of generous terms to Western oil companies, and a declaration of commitment to NATO's eastward expansion initiative while attempting to maintain equilibrium in its relations with Russia. Because of its geostrategic importance to the West by virtue of its offshore oil reserves in the Caspian Sea as an alternative to Persian gulf oil, Azerbaijan was becoming better known worldwide for its oil than its fighting with Armenia on Karabagh. ${ }^{533}$ Having oil reserves produced exceptional

\footnotetext{
${ }^{530}$ Yelena Oyliyeva, "Aliyev Promises Caspian Oil to Ankara: Absence of Peace Treaty with Chechnya Cuts Russian Oil Route,” Kommersant-Daily, 7 May 1997, p. 2, in Armenian News Network, groong@usc.edu, accessed by 7 May 1997.

${ }^{531}$ It is interesting to note that from the occupation of Baku in January 1990 through Mutalibov's attempt to return to power in April 1992 to the Huseyinov affair. There had been several direct/indirectly Russian interventions in Azerbaijan's internal political affairs.

${ }^{532}$ Douglas Clarke, "The Russian Military Presence in the 'Near Abroad'," OMRI Program Brief, 27 September 1995.

${ }^{533}$ Marcus Menzel, Doomed to Cooperate? American Foreign Policy in the Caspian Region, (Berlin: Peter Lang, 2003), p. 71; Joseph Stanislaw and Daniel Yergin, "Oil: Reopening the Door," Foreign Affairs, September/October 1993, vol. 72, no. 4, p. 91; and Forsythe, 1996, p. 181.
} 
financial power that transformed the position of Azerbaijan vis-à-vis Russia and western major powers from dependence into asymmetric interdependence. The Azerbaijani government accepted to transfer Azerbaijani oil to the world market through Turkey instead of through Russia, even under the tremendous Russian pressure. That is a clear indication that Azerbaijan was able to advance its interests against Russian pressure.

\section{4b. Leadership Perceptions on Foreign Policy}

\section{Ayaz Mutalibov (1991-1992)}

Mutalibov was attached to Moscow not just by inclination and career path as a Communist Party member but by the very direct way in which he owed his position to Moscow's involvement. On January 7, 1990, Soviet troops were sent into Baku and suppressed the APF demonstrations at the cost of hundreds of civilian casualties. APF leaders and activists were arrested, the general secretary of the Azerbaijani Communist Party, Vezirov, was fired and Mutalibov became the General Secretary of the Azerbaijani Communist Party. ${ }^{534}$ Therefore, from the beginning of his presidency, Mutalibov was handicapped by the fact that he had come to power in the shadow of Soviet tanks. The intervention of the Soviet military had produced strong anti-Russian sentiments among the Azerbaijani people. After the Soviet Union collapsed, the Mutalibov regime revealed its pro-Russian orientation, and made contact with the new Russian leadership. In addition, Mutalibov resisted the formation of a national army and wanted to keep the Russian army in Azerbaijan.

During the early months of his rule, Mutalibov realized that among the Azerbaijani elites and public, national sentiments ran high. Therefore, he gradually

\footnotetext{
${ }^{534}$ Swietochowski, 1995, p. 206.
} 
adopted a nationalist façade and, at the same time, only a handful opposition groups and parties were allowed limited participation in political life. In September 1990, Mutalibov ran unopposed for the presidency of Azerbaijan and was elected as the first president of independent Azerbaijan. ${ }^{535}$

As the AFP was taking shape during 1990-91, its members were to various degrees pro-Turkish. Other groups were oriented towards Islam, and, to some degree, Iran. Mutalibov's close relationship with Russia brought some advantages to Azerbaijan at first. Moscow assumed a more sympathetic stance to Azerbaijan on the issue of Karabagh. Despite the fact that Mutalibov was pro-Russian, Azerbaijan's relations with Russia during his presidency were not always easy. Because of strong anti-Russian feelings, Mutalibov adopted an ambiguous, wait-and-see attitude toward Russia. During this period, Azerbaijan also started dipomatic relations with both Turkey and Iran. Mutalibov supported the Moscow coup in August 1991. ${ }^{536}$

Barely half a year after assumption of the presidency, by March 1992 Mutalibov was ousted by the parliament in the wake of the massacre of refugees fleeing Khojaly, a town the Armenian forces had taken with the help of the $366^{\text {th }}$ Russian Regiment stationed in Karabagh. There the situation turned into ethnic cleansing of the local Azerbaijani minority with ineffective opposition on the part of the fledgling Azerbaijani army. ${ }^{537}$

\footnotetext{
${ }^{535}$ Hunter, 1994, p. 71.

${ }^{536}$ Swietochowski, 1995, p. 214.

${ }^{537}$ Swietochowski, 1995, p. 219; and Hunter, 1994, p. 73.
} 


\section{Abulfaz Elchibey (1992-1993)}

Elchibey, the head of APF, was the first democratically elected president of Azerbaijan in June 1992. He was president for only one year. As a typical Azerbaijani intelligentsia and a Soviet dissident he struggled against Soviet cultural policies in the 1980s. Elchibey was known for his closeness to Turkey, concern for Azerbaijani nationals in Iran, and suspicion about Russian activities in the region. The Elchibey government faced enormous political, social, and economic problems.

While he was president, he brought a different set of political orientations to Azerbaijani foreign policy. First, while he did not express his suspicions of Russia as crudely as Gamsakhurdia, he openly expressed his aspiration to decrease Azerbaijan's political dependence and ties with Russia and developed a strategic partnership with Turkey. He decisively rejected Mutalibov's move toward Azerbaijani membership in the CIS. Second, he considered Azerbaijan's future as being tied closely with that of Turkey and the West. Elchibey primarily emphasized the vital development of Azerbaijan's relations with Turkey at all levels. He believed that having strategic relations with Turkey and the West were essential to advancing Azerbaijan's interests. Therefore, during Elchibey's presidency Russian influence appeared very much on the decline; on the other hand, Azerbaijan-Turkish relations soared as the key strategic partnership. In other words, because of Elchibey's pro-Turkish ideas and policies, Azerbaijan had taken itself out of the CIS, Turkish influence in Azerbaijan grew rapidly, such developing strategic partnership relations. ${ }^{538}$

\footnotetext{
${ }^{538}$ Elizabeth Fuller, "Iran and the Karabakh Mediation Process," RFE/RL Report, 25 February 1994, vol. 3 , no. 8, p. 31 .
} 
Elchibey's policy of rapprochement with Turkey was meant both as a substitute for the long Russian presence in the country and as a stimulus for a Kemalist statebuilding model for Azerbaijan. For example, after his election in June 1992, Elchibey’s first foreign trip was to Turkey. Elchibey went to the mausoleum of Mustafa Kemal Ataturk, the founder of the Turkish republic. There he signed the guestbook, "your modest soldier, Elchibey". Consequently, Elchibey's proclamation of his devotion to Ataturk and his model of a secular state was an indication of Elchibey's foreign policy approach. During Elchibey's visit in November 1992, he also signed an agreement to secure 250 million dollar credit. ${ }^{539}$

Elchibey was under considerable pressure from Russia on the question of Russian forces in the country and including a Russian oil company in the deal on the Azerbaijani oil reserves. Elchibey first removed Azerbaijan from the CIS. This step prompted a quick Russian retaliation. Russia first raised import duties on industrial products, causing numerous cancellations of contracts between Azerbaijani and Russian businesses. In addition, Russia was openly threatening the Elchibey government, saying that if the Elchibey government did not agree to an oil deal favorable to Russia, Moscow would allow the Armenians to take this or that city in Azerbaijan. ${ }^{540}$ This explains why Elchibey was so keen to drive out all Russian troops on Azerbaijani territory. Elchibey felt that the sooner Russian troops were out of the country, the sooner the conflict would be resolved. However, the Armenians came to the opposite conclusion: if Russian troops were to leave Azerbaijan, they could settle in Armenia and provide stronger Russian support for the

\footnotetext{
${ }^{539}$ Daniel Sneider, "Big Power Rivalry in the Caucasus," Christian Science Monitor, 22 July 1993, p. 2; and TRT Television Network, 2 November 1992.

${ }^{540}$ Aves, 1995, p. 229.
} 
Armenian side in the conflict. Elchibey's demands to pull the Russian military forces out of Azerbaijan provided an opportunity for Armenia to allow the use of Russian soldiers as mercenaries and Russian military equipment on the Armenian side in the Karabagh conflict. ${ }^{541}$ In the end, it was the worsening conditions at Karabagh that hastened Elchibey's fall, particularly the loss of district of Kelbajar in the spring of 1993.

Elchibey did not have good relations with Iran. Elchibey's devotion to the model of a secular state, his pro-Turkish approach and his rhetoric on uniting southern (Iranian) Azerbaijan with northern Azerbaijan was seen by Iranian ruling elites as a threat to their state and regime. Elchibey had been making statements about the two Azerbaijanis in the following vein: "As an independent state rises in the north of Azerbaijan, it will make it easier for freedom to grow in the South. ${ }^{, 542}$ The Iranian government was afraid that Elchibey's nationalist rhetoric might influence the Azerbaijani population in Iran, which is one-third of Iran's population. Thus, Elchibey's nationalist rhetoric and interest in greater Azerbaijan, combined with a more Turkish identity for Azerbaijan, led to hostility and suspicion between Azerbaijan and Iran and the gravitation of Iran toward the Armenian side in the Karabagh conflict. As a result, the Iranian ruling elites considered his presidency as a threat to Iranian territorial integrity.

Finally, Elchibey as a president became a target of criticism by different political elites and groups, including within his own party, APF, for being naïve, inexperienced and ineffective. Elchibey fell because his politically inexperienced romantic nationalism

\footnotetext{
${ }^{541}$ Rajan Menon, "After Empire: Russia and the Southern 'Near Abroad'," in The New Russian Foreign Policy, Michael Mandelbaum, ed., (New York: Council of Foreign Relations, 1998), p. 129.

${ }^{542}$ Tadeusz Swietochowski, "Azerbaijan: A Borderland at the Crossroads of History," in The Legacy of History in Russia and the News States of Eurasia, S. Frederick Starr, eds., (Armonk: M.E. Sharpe, 1994), p. 294; and Azadliq, 19 July 1991, p. 9.
} 
proved unable to control old bureaucrats and the security apparatus; no doubt, his failure to win the Karabagh war was the coup de grace. Nevertheless, Elchibey expressed Azerbaijan's deep-rooted desires and fears more clearly than any other political figure in Azerbaijan. These were: liberation from Russian domination, drawing closer to Turkey and establishing firm ties with their ethnic brothers across the Araxes River in Turkey and Iran, and guarantee of national survival in the new international and regional political system. To this extent, Elchibey's foreign policy orientation was accepted even somewhat by Aliyev.

\section{Haydar Aliyev (1993-2003)}

After a long time building his career as a Communist party member during the Soviet era, Aliyev had torn up his Communist Party card and spent some time in his native province of Nakhichevan in late 1980s. He was elected as the chair of the Nakhichevan Autonomous Region and a parliamentarian in the Supreme Soviet of Azerbaijan. He governed the region as an independent entity. He conducted his own foreign policy and signed agreements with Turkey and Iran. ${ }^{543}$ For example, Aliyev sought and received economic and humanitarian assistance from Turkey and Iran. He also negotiated with Armenia without the Azerbaijani government in Baku to pull out its military forces from the border between Armenia and Nakchichevan and allowed the delivery of goods from Iran through Armenia to Nakhcihevan during the highest point of Armenian-Azerbaijani fighting over Karabagh in late 1992 and early $1993 .{ }^{544}$

\footnotetext{
${ }^{543}$ Swietochowski, 1994, p. 294.

${ }^{544}$ Interfax, 3 February 1993, in FBIS-SOV, 4 February 1993, p. 55.
} 
He decided it was important for Azerbaijan to maintain its independence from Moscow and control its own resources. However, he was also particularly aware of the length and power of Moscow's reach in the former Soviet land. He believed that Azerbaijan could not manage without Russia. He agreed that Azerbaijan should become a member of the CIS to achieve some concessions from Russia but he decided to stand firm in all matters concerning the economic and political sovereignty of Azerbaijan and use Azerbaijani energy resources to attract international attention to his country. He was more balanced than Elchibey and knew what Russia's capabilities were and what Russia could do.

After Elchibey was ousted by Huseyinov's coup, Aliyev was appointed as acting president of the country. During the time immediately after Elchibey’s ouster, Aliyev faced a situation of considerable complexity in legitimizing his authority externally and consolidating his power internally. Turkey recognized Elchibey as the lawful president of Azerbaijan. However, after the Milli Majlis elected Aliyev as its chairman and transferred power from Elchibey to Aliyev, Turkish foreign minister Hikmet Cetin commented on the action as "a legitimate decision taken in accordance with the Azerbaijani Constitution. ${ }^{, 545}$ Aliyev held first a referendum on the fate of Elchibey and consolidated his authority by public support. Elections were called rapidly and his position as president was confirmed in October 1993. ${ }^{546}$ Aliyev offered Itibar Memedov, a founding APF leaders, who left AFP and later established his own party and emerged as a pro-Turkish politician in Azerbaijan, the post of Foreign Minister. When Memedov refused Aliyev's

\footnotetext{
${ }^{545}$ ITAR-TASS, 25 June 1993.

${ }^{546}$ Elizabeth Fuller, "Azerbaijan at the Crossroads," in Challenges for the Former Soviet South, Roy Allison, ed., (Washington, D.C.: Brookings Institution Press, 1996), p. 118.
} 
offer, Aliyev offered the position to Azerbaijan's ambassador to the United Nations, former prime minister Hasan Hasanov. Since Hasanov had had good relations with the APF and Turkey, Aliyev's appointment of Hasanov was a signal to Turkey that Aliyev was not totally turning away from Turkey. This way, Aliyev was trying to make sure that, if needed, he could turn for Turkish assistance against both Armenia and Russia.

Surat Huseyinov was given the position of Prime Minister but within months Azerbaijan had lost important territory to the Armenian forces and the economy began a downward spiral that only foreign investment would have been able to stem. Aliyev renegotiated an oil deal with the international consortium led by the American and British oil corporations. Within days of the signing of the oil agreement, Huseyinov was again involved in an attempted coup against the Aliyev government (of which he was the prime minister); the aim of this coup was to bring Mutalibov, who lived in Moscow, back to power. Aliyev, through appealing to popular support and relying on international backing for his country's independence and right to control its own oil, survived the attempted ouster by Huseyinov. He united the opposition, the regions and the business community in support of his position. Briefly, Aliyev is known as a 'Machieavellian statesman', well capable of manipulating internal and external conditions to keep him in power. ${ }^{547}$

Moreover, Aliyev used his Soviet-era experience and authority to restore stability where previously chaos reigned. His leadership style was decidedly authoritarian. He as president made all significant decisions. In other words, he alone defined and ruled the country. Criticism of the president was routinely censored. His regime moved quickly to suppress Elchibey's supporters in the APF. The government arrested several APF leaders,

${ }^{547}$ Alec Rasizade, “Azerbaijan after a Decade of Independence: Less Oil, More Graft and Poverty,” Central Asian Survey, December 2002, vol. 21, no. 4, p. 365. 
using force to break up street demonstrations. Aliyev had surrounded himself with the old nomenklatura who ruled with him when he was communist leaders of Azerbaijan in the 1970s and 1980s. ${ }^{548}$ Aliyev skillfully used oil, pipelines, and promises to build up his personal authority.

Aliyev launched a number of small scale offensives against the Armenian forces. These offensives were the most intense fighting of the entire war. Azerbaijani forces achieved some initial success but gained little on the ground. The casualty rates were high on both sides. During this period of intense fighting the Russians pressed hard for a ceasefire. It was during this period that Russian mediation efforts sidelined the CSCE/OSCE Minsk Group. Russian defense minister Grachev and Kazimirov were shuttling back and forth from Erevan to Baku.

Aliyev promised Karabagh Armenians "wide" autonomy within Azerbaijan and repeatedly stated that Azerbaijan was ready to consider the installation of a new oil pipeline via Armenia in case the Karabagh conflict was settled. On the other hand, Aliyev described the Armenians as aggressors and stated that Azerbaijan would definitely win back all the land it had lost, including Karabagh.

In April 1999, both Aliyev and Kocharian attended the summit in Washington, D.C. marking the fiftieth anniversary of the founding of NATO. They had an informal meeting and a new dialogue started between them. They agreed that they needed to make painful and unpopular concessions. Basically, Azerbaijan would accept Karabagh as part of Armenia and Armenia would agree to provide a land corridor for Nakhichevan to the other part of Azerbaijan. Many Azerbaijani political elites rejected the plan. In October

\footnotetext{
${ }^{548}$ Fuller, 1996, p. 129.
} 
1999, three of Aliyev's top foreign policy advisors resigned. They were his long-term foreign policy advisor, Vafa Guluzade, the head of the presidential secretariat, Eldar Namazov, and foreign minister Tofiq Zulfuqarov. ${ }^{549}$ This instance is a clear indication that Aliyev had the final words for Azerbaijani foreign policy.

Aliyev skillfully played the oil card game to apply pressure on Russia. The Azerbaijani oil reserve is used as a carrot, i.e., promises of the pipeline passing through Russia, and a stick, i.e., threats to lay the pipeline bypassing Russian territory. Aliyev also moved with determination to attract foreign oil corporations to develop the Azerbaijani sector of the Caspian Sea, adding momentum to a process begun by his predecessor Elchibey. He concluded new oil deals with Western, Russian and Turkish oil companies in his first year of power. After long and difficult negotiations, the agreement known as "the contract of the century" was signed on September 20, 1994, in Baku. ${ }^{550}$ The Russian company Lukoil was given a 10 per cent stake in Azerbaijan's own share and the right to participate in decisions taken by the production team consisting of Azerbaijani, Russian, British, American, Turkish, Norwegian and Saudi Arabian companies. Aliyev hoped to utilize the contract in order to win the U.S. support in negotiations regarding the status of Karabagh.

In the realm of foreign policy Aliyev's return to power in Baku signaled the end of the "special relationship" that Elchibey had cultivated with Turkey. Aliyev hoped that if he shifted Azerbaijan's foreign policy orientation away from Turkey, Russia would

\footnotetext{
${ }^{549}$ De Waal, 2003, pp. 263-264.

${ }^{550}$ Robert Ebel and Rajan Menon, "Introduction: Energy, Conflict, and Development in the Caspian Sea Region," in Energy and Conflict in Central Asia and the Caucasus, Robert Ebel and Rajan Menon, eds., (Lanham: Rowman \& Littlefield Publishers, Inc., 2000), p. 5.
} 
take a more balanced stand in the Azerbaijan-Armenian conflict. Therefore, Aliyev reversed some of his predecessor's pro-Turkish decisions. He canceled Elchibey's plan for the oil and pipeline deal. Azerbaijan's visa requirement for foreign nations was extended to Turkey, which had previously been exempt. ${ }^{551} \mathrm{He}$ also decided to join the CIS, hoping that Russia would provide security and recognize Azerbaijani territorial integrity.

However, as Russian pressure mounted in the spring of 1994 and Huseyinov challenged Aliyev's leadership, Aliyev wanted to ease Turkish fears and try to develop new relations with Turkey. ${ }^{552}$ In other words, Aliyev wanted to get rid of the mistrust between Azerbaijan and Turkey had arisen between the two countries in the wake of the ouster of the pro-Turkish Elchibey. ${ }^{553}$ The major development in this regard was the visit of the Turkish Foreign Minister to Baku in fall 1993. Aliyev tried to reassure Turkey on the pipeline issue and Azerbaijan declared that Turkey would continue to train Azerbaijani military personal. ${ }^{554}$

Furthermore, Aliyev visited Turkey in spring 1994 to restore good relations and secure diplomatic support. This official visit to Turkey marked a new phase in TurkishAzerbaijani relations and put an end to the split between the two countries that followed

\footnotetext{
${ }^{551}$ Elizabeth Fuller, "The Transcaucasus: War, Turmoil, Economic Collapse,” RFE/RL Research Report, January 1994, vol. 3, no. 1, p. 54.

${ }^{552}$ Dimitry Aliev end Georgy Bovt, "Turkish Prime Minister's Foreign Tour: Given the Political Will," Komersant, 12 July 1993, p. 4, in The Current Digest of Post-Soviet Press, 1993, vol. XLVII, no. 28, pp. $21-22$.

553 "Demirel Comments on Situation in Caucasus," Ankara TRT Television Network, 30 October 1995, in FBIS-WEN-95-211, 1 November 1995, p. 28.

554 “Baku Praises Cetin’s Visit, Turkish-Iranian Aid,” FBIS/SOV-93-18, 21 September 1993, p. 50.
} 
Elchibey's ouster. ${ }^{555}$ Now Aliyev sought to portray himself as a born again pan-Turkish statesman, proclaiming at a state banquet that "we are two states [but] one nation". His talks with the Turkish leadership and the terms of the signed agreements signaled a new chapter in Azerbaijan's foreign policy. ${ }^{556}$

Nevertheless, in Russia as well as in the West, the first impression of Aliyev's government was that it was pro-Russian. Azerbaijan joined the CIS even though this step could not reverse the invasion and occupation of one-fifth of Azerbaijan territory by the Armenian forces and Aliyev had to appeal to the international community and the West in particular to provide more support to Baku. At the same time Aliyev resisted Russian demands, such as the Russian peacekeeping plan according to provide peacekeeping forces in Karabagh. He also refused to allow Russia to restore its permanent military presence in Azerbaijan through the establishment of military bases. ${ }^{557}$ Aliyev was nevertheless aware that such denials entailed risks to alienate Russia because of high level of Russian influence in the region and in Azerbaijani domestic politics in previous years. Therefore, Aliyev at first promised to lease the Gabala radar station to Russia, while later he merely agreed to discuss the matter. Moscow proved unable to reach any agreements with Aliyev on the station. ${ }^{558}$ Therefore, Aliyev was playing the Russian card very successfully to stay in power. When Russian assistance became vital for Aliyev to

\footnotetext{
${ }^{555}$ Elizabeth Fuller, "Russia, Turkey, Iran and Karabakh Mediation Process," RFE/RL Research Report, 25 February 1994, vol. 3, No. 8, p. 35.

${ }^{556}$ See, “Aliyev, Turkey’s Demirel Sign Friendship Accord,” FBIS/SOV-94-028, 10 February 1994.

${ }^{557}$ Elkhan E. Nuriyev, "Conflicts, Caspian Oil, and NATO: Major Pieces of the Caucasus Puzzle," in Crossroads and Conflicts: Security and Foreign Policy in the Caucasus and Central Asia, Gary K. Bertsch, et al., (New York: Routledge, 2000), p. 143.

558 "Result of Pavel Grachev's Visit to the Transcaucasus: Minister at the 'Point of Return'; A Tour of Stalin Sites,” Kommersant, 25 March 1995, p. 4, The Current Digest of the Post-Soviet Press, 1995, vol. XLVII, no. 12, p. 22.
} 
stay in power, he accepted some of Russian demands, such as becoming a member of the CIS, but rejecting some Russian demands, such as having Russian troops on Azerbaijani soil, which might result in total Russian control on the country. On the other hand, when Aliyev secured his authority within Azerbaijan and assistance for other major powers, such as the U.S. in the second half of 1990s, he balanced Russian influence with U.S. involvement.

\section{4c. Azerbaijan and Russia}

Azerbaijani-Russian relations are quite complicated with a variety of factors impacting on them. Although the majority of the Azerbaijani population remembered the Black January events of 1990, the country neverthless had to be reconciled with the former imperial center. Among the more important reasons guiding Azerbaijani foreign policy toward Russia have been remaining Soviet-era political and economic ties and issues relating to Russian strategic objectives in the Caucasus. Moreover, the significance of Azerbaijan's relations with Russia depended greatly on the personal preferences of the Azerbaijani leadership in the 1990s.

Azerbaijan's relations with Russia have gone through four distinct phases since the collapse of the USSR. First, the first president of Azerbaijan, Mutalibov was very loyal to Russia. He pursued a policy that was hard-line domestically and pro-Moscow externally. Mutalibov's close relationship with Russia brought some benefits to Azerbaijan at first; for instance, Russia adopted a more sympathetic stance on the Karabagh issue. However, many Azerbaijani political elites were expecting more from Russia. For that reason they were disappointed by the lack of Russian support on the 
Karabagh issue. In addition to that, relations deteriorated significantly because of disagreements over the oil of the Azerbaijani Caspian Sea coast.

Second, the Elchibey government abandoned Mutalibov's policy on Russia and inclined towards Turkey and the Western world in general. Elchibey asked Russia to close all former Soviet military bases and withdraw Soviet/Russian military forces from Azerbaijan. He also excluded Russian oil companies from the international consortium which was established to exploit the Azerbaijani oil. Therefore, there was tension between Azerbaijani and Russia during the Elchibey's tenure.

Third, the overthrow of the Elchibey regime in July 1993 and his replacement by Aliyev was, at the beginning, of benefit to Russia, given Aliyev's past as a Politburo member of the Soviet Union during the early 1980s. Despite considerable popular opposition in Azerbaijan, Aliyev managed to convince the ruling elites of Azerbaijan to join the CIS. It became clear, however, that joining the CIS alone would not satisfy Russia, which, it turned out, had other demands as well. Moreover, the Russian government's unwillingness to help Azerbaijan in the Karabagh conflict and the Russian military's assistance to the Armenian forces there pushed Aliyev to resist Russian demands such as introducting Russian border troops and opening Russian military bases in the country. Such resistance had hardened the Russian Foreign Affairs Ministry's objections to an agreement with the international oil consortium to develop Azerbaijan's Caspian oil even after the Russian oil company, Lukoil, was included the consortium with a 10 percent of share.

Furthermore, Russia closed its own border with Azerbaijan in fall 1994, pointing in justification to the infiltration of guerillas from Azerbaijan to Chechnya during the first 
Chechen war. ${ }^{559}$ Inasmuch, however, as Azerbaijan does not share a common border with Chechnya, the Russian claim may be viewed with considerable doubt. In fact, the decision was taken at the height of Russian pressure on the Azerbaijani government not to sign the oil contract with the BP-led AIOC. This unilateral closure of the border thus worsened Azerbaijan-Russia relations. Moreover, Russia, eager for a bigger share of Azerbaijan's oil and unhappy at Aliyev's refusal to accept the posting of Russian troops in his country, considered applying pressure on Azerbaijan through Russia's traditional ally in the region, Armenia.

Moreover, the Yeltsin government was seeking to use the early-warning air defense radar station in Gebele, one of the largest in the former USSR, and occupying one of the most important strategic positions on the southern border of Russia. Aliyev promised to lease the station to Russia but then changed his mind and forgot his promise. He also revised his promise to guard the Azerbaijani border with Iran jointly with Russian border guards. ${ }^{560}$

Russia insisted on being the main mediator in the Karabagh conflict. Neither Armenia nor Azerbaijan would contest this, since Russia was in effect the sole supplier of weapons to both sides in the conflict. Any agreement on Karabagh excluding Russia was thus impossible. The Azerbaijani government also realized that the United States and Western Europe de facto recognized the Caucasus as being within the 'Russian sphere of influence' in early the 1990s with their 'Russia-first' policy. One of the first foreign

\footnotetext{
${ }^{559}$ Olcott, Summer 1994, p. 359.

${ }^{560}$ Georgiy Bovt, “In Politics, a Draw Often Means Victory,” Kommersant, 10 October 1995, p.1 and p. 4; and "Daily Analyze Implications of Caspian Oil Route Decision," FBIS-SOV-95-197, 12 October 1995, pp. $18-20$.
} 
policy actions of the Aliyev government was to improve relations with Moscow. As a first step in this direction, Azerbaijan joined the CIS. Aliyev hoped that Russia would help resolve the Karabagh conflict in a way favorable to Azerbaijan. In early April, Russian special envoy Vladimir Kazimirov visited Armenia and Azerbaijan with a delegation from the CIS Interparliamentary Assembly, where they discussed with the Armenian and Azerbaijani leaders "the role that the CIS can play in achieving peace in this disturbed region." ${ }^{, 561}$ Then, parliamentary delegations from Armenia, Azerbaijan, Russia, Kyrgyzstan and Karabagh instigated negotiations in Bishkek on 4 May 1994 under the aegis of the CIS Interparliamentary Assembly. A protocol (called the Bishkek Protocol) was proposed that called for a ceasefire to begin on 8 May, to be followed by supplementary talks on the disengagement of the warring parties, withdrawal of military forces from occupied territories, discontinuation of energy and transportation blockades, return of refugees and prisoners of war and resolution of Karabagh's final legal status. ${ }^{562}$

After at first refusing to sign the protocol, the Azerbaijani delegation initialed the agreement after attaining two minor adjustments to its text. Aliyev incurred a substantial risk in endorsing the Bishkek Protocol. The Azerbaijani opposition protested the measure resolutely because it implied the dispatch of largely Russian peacekeeping forces to the country at a future date, thus raising the question not only of losing Karabagh but also jeopardizing Azerbaijan's sovereignty. On the other hand, if the Azerbaijani delegation had not initialed the protocol, he feared a reaction from Russia encouraging Armenian forces to capture Azerbaijani towns and even a Russian-support coup d'etat similar to

\footnotetext{
${ }^{561}$ ITAR-TASS World Service, 2 April 1994, in FBIS-SOV-94-064, 4 April 1994, p. 55.

562 Snark, 6 May 1994, in FBIS-SOV-94-089, 9 May 1994, p. 2.
} 
that which had toppled his predecessor, Elchibey. As it turned out, the nature of the Bishkek Protocol offered Aliyev the opportunity to prevent potential challenges from both domestic and external sources. Because the Bishkek Protocol bound Azerbaijan to a cease-fire with only the promise of further negotiations, it gave Aliyev a bit of breathing room with which to strengthen his own hand. ${ }^{563}$ By committing to a Russian-mediated halt to hostilities, Aliyev may have hoped to put up the façade that he was beginning to given in to Moscow's demands, thus staving off temporarily any potential threat to his power from that angle. ${ }^{564}$ At the same time, the Azeri leader may have sought to use nonbinding aspects of the Bishkek Protocol- that is, the commitment to continued negotiations- to assuage concerns of the domestic opposition over the prospect of Russian peacekeepers. In order to be successful, Aliyev perceived the need to bid for time in the hope that the CSCE would become more involved in the mediation process. ${ }^{565}$

The first stirring of a renewed CSCE role in the Karabagh mediation process emerged in the aftermath of the Bishkek meeting. In mid May 1994, Minsk Group chairman Jan Eliasson shuttled back and forth between Erevan and Baku and offered to dispatch a small multinational force of CSCE ceasefire observers to the Karabagh within a short time of its acceptance by Armenia and Azerbaijan. The CSCE's initiative in the peace process made Aliyev confident. ${ }^{566}$

\footnotetext{
${ }^{563}$ Croissant, 1998, p. 110.

${ }^{564}$ Umit Ozdag, "From USSR to Russian Federation,” Avrasya Dosyasi, 3, 4, Winter 1996, p. 184.

${ }^{565}$ Azerbaydzhan, 14 May 1994, in FBIS-SOV-94-056, 26 May 1994, p. 83.

${ }^{566}$ Croissant, 1998. Aliyev blasted Kazimirov during a one-on-one meeting; 'Russia cannot deploy body first. Russia's troops in Azerbaijan by itself. They will have to tread over my dead body first. Russia's troops can be deployed within the framework of an international force, which the CSCE will establish." Quoted in Hurriyet, 5 June 1994, in FBIS-WEU-94-110, 8 June 1994, p. 53.
} 
As Moscow lobbied to conclude its version of a comprehensive political settlement to the Armenia-Azerbaijan conflict in the summer of 1994, talks between SOCAR and the international consortium were speeded up, due to Aliyev's growing disappointment with the Russian-dominated Karabagh peace process. Viewing a major contract with western major oil corporations, such as Amoco and BP as a way to strengthen Azerbaijan's position vis-à-vis Russia and strengthen Azerbaijan's sovereignty as well as its ties with the West, the 'Contract of the Century' signed on 20 September $1994 .{ }^{567}$

Competition among major and regional powers over oil and pipelines also led to tensions and security problems in the region. Azerbaijan signed several oil exploitation agreements with Western corporations, in spite of the intense opposition of the Russian Foreign Ministry, which objected to Azerbaijan's claiming that the Caspian Sea had been divided into sectors since the 1970s. However, Russian government and business circles had been split between security considerations (Foreign Ministry, Defense Ministry) and economic considerations (Lukoil, Rosneft, Oil and Fuel Ministry and parts of the government), with the latter becoming stronger during the second half of the 1990s. ${ }^{568}$ This conflict among different Russian governmental and business circles indicated that cleavages inside the different states institutions and states, creating coalitions across national boundaries within the region, were in fact an important factor that shaped Caucasus politics.

\footnotetext{
${ }^{567}$ Turan, 20 September 1994, in FBIS-SOV-94-183, 21 September 1994, p. 81, and Bess Brown, 'Aliyev Defends Oil Deal,” RFE/RL Daily Report, no. 183, 26 September 1994.

${ }^{568}$ Ali Granmayeh, "Legal History of the Caspian Sea," in The Caspian: Politics, Energy and Security, Shirin Akiner, ed., (London: RoutledgeCurzon, 2004), p. 23.
} 
Pressure from Moscow had, however, succeeded in inserting the Russian oil company, Lukoil into the international consortium. Lukoil was offered a $10 \%$ stake in the Azerbaijani oil consortium by the Azerbaijani government. The Russian Foreign Ministry, in fact, protested Lukoil's signature of the "Contract of the Century" with Azerbaijan at a time when it was still pressing its own claim on the Caspian Sea and rejected Azerbaijan's claims to Caspian Sea's resources. ${ }^{569}$

Fourth, while Russia took up opposition to the Azerbaijani oil deal through the fall of 1994, the contract's signing had further outcomes in Azerbaijan. On 30 September, two close associates of President Aliyev were gunned down within two hours of one another by unidentified gunmen. Aliyev responded to the crisis by declaring a state of emergency in the capital and was quick to level blame for the alleged coup attempt. Although Prime Minister Huseyinov denied involvement in the coup attempt, he was sacked from his post. Huseyinov had criticized both of the president and the oil deal. ${ }^{570}$

Aliyev accused Russia of supporting the attempted coup d'etat against his leadership in $1994 .{ }^{571}$ He portrayed a direct link between the attempted coup and the signing of the oil contract; he implied that Russia was responsible ultimately for the coup due to his support of the oil deal and his continuing refusal to accept a Russian troop presence in the country. ${ }^{572}$ Thus, Aliyev secured his position as the leader of the country

\footnotetext{
${ }^{569}$ Nasib Nasibli, “Azerbaijan: Oil and Politics in the Country's Future," in Oil and Geopolitics in the Caspian Sea Region, Michael P. Croissant and Bulent Aras, eds., (Westport: Praeger, 1999), p. 107.

${ }^{570}$ Le Figaro, 11 October 1994, in FBIS-SOV-94-197, 12 October 1994, pp. 60-61.

${ }^{571}$ Sokhbet Mamedov, "Russian Trail in Flight of Azerbaijani Ex-Prime Minister,” Izvestia, 25 October 1994, p. 2, in The Current Digest of the Post-Soviet Press, 23 November 1994, vol. XLVI, no. 43, p.20.

${ }^{572}$ Croissant, 1998, p. 117. In the Azerbaijani president's own words," "it is possible to think that the events which followed the signing of the contract are merely coincidental. But they can also be seen as a logical progression... All these facts come together and aim to threaten Azerbaijan's independence by
} 
and strengthened his leadership with the oil deal against potential internal and external threats.

Aliyev led to a shift in Azerbaijan's orientation away from Russia and toward closer cooperation with the West. Thus, by at the end of 1994, Azerbaijan had joined NATO's Partnership for Peace Program, established close ties with the EU, had become a key link in the EU-sponsored Central Asia-Caucasus-European transport and communications corridor, and became a member of GUAM, a pro-Western coalition of post-Soviet states. ${ }^{573}$ Moreover, despite the preliminary agreement under which early oil from the Azerbaijani Caspian shores was supposed to begin flowing along the BakuGrozny-Novorossiysk route as early as 1998, Aliyev began to talk about an alternative route through Turkey during his visit there in 1997. He declared that Azerbaijan preferred the Turkish option for transporting oil over the Russian one. ${ }^{574}$

\section{4d. Other Players}

\section{United States}

The United States government at first relied on Turkey to advance American interests in Azerbaijan in the 1990s. While Azerbaijan was seen a buffer state by the U.S. officials because of its potential role against its two powerful neighbors, Russia and Iran, the country's huge oil deposits pushed Azerbaijan to a new level of importance in the eyes of the U.S. government and business circles. The United States considered the

overthrowing the existing government which is its guarantor." See, Aliyev's interview in Le Figaro, 11 October 1994, in FBIS-SOV-94-197, 12 October 1994, pp. 60-61.

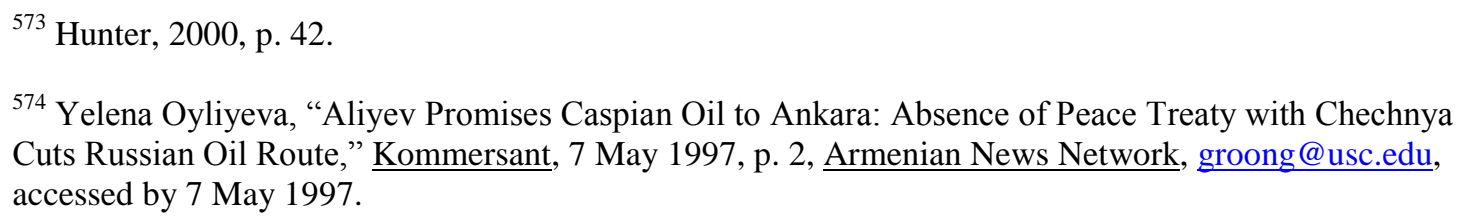


region strategically significant because of oil interests and, after the terrorist attacks in the United States on September 11, 2001, for its war on terrorism. The United States government shifted its foreign policy approach in the second half of the 1990s. The United Stated began to become directly involved in the region as a global power after Clinton met with Aliyev, first in September 1994, then in October 1995 in New York, and finally in August 1997 in Washington, D.C.; of particular importance was the attendance of William White, the American Deputy Secretary of Energy at the signing ceremony for the 'Contract of the Century' in Baku on September 20, 1994. Clinton thus recognized the importance of Azerbaijan. He wrote a letter to Aliyev stating, "I am pleased with the development of relations between the United States and Azerbaijan in recent years (and) by the rapid growth of our commercial and investment ties." ${ }^{.575}$ The biggest shares of the consortiums are controlled by the United States and British corporations, with total shareholdings of 65 percent in the consortium. So the West's ever growing interest in Caspian oil resources has a practical basis. While Russia retains a share in the consortium, exploiting the oilfields of Shirag, Azeri and Guneshli off the Azerbaijani coast of the Caspian Sea, Western influence was becoming dominant. ${ }^{576}$ The post of Caspian Coordinator was established in the United States Department of State. Influential figures of American politics actively involved in Azerbaijani oil or encouraging investment to Azerbaijan are included; former Secretaries of State Henry Kissinger and James Baker, Vice President Dick Cheney, former Senator and Treasury Secretary Lloyd Bentsen, former White House chief of staff John Sununu, and former

\footnotetext{
${ }^{575}$ Pashayev, 2006, p. 81.

${ }^{576}$ Nasibli, 1999, p. 108.
} 
national security advisers Brent Scowcroft and Zbigniew Brzezinski. These and other figures helped persuade the Congress and the Clinton administration to embrace Azerbaijan. Therefore, an Azerbaijani oil lobby emerged in the United States to act as a counterbalance to the Armenian diaspora. ${ }^{577}$ The foundation for American interests is removing the monopoly of the Middle East over the world's oil supplies through the exploitation of Caspian resources. In addition, the United States does not want to see a Russian monopoly on the Caspian's Sea's resources. The United States oil companies are participating in the international consortium in Azerbaijan and they lobby for Azerbaijan in the Capitol and White House. ${ }^{578}$ Therefore, Azerbaijan gained more international significance and attention.

Moreover, Azerbaijan was using its oil resources to make the United States lean to the Azerbaijani side on the Karabagh issue. When Western oil investment to Azerbaijan started to flow in 1996-1997, the profile of the OSCE Minsk Group changed too. The United States, France and Russia became co-chairs of Minsk Groups. ${ }^{579}$ In other words, the new American commitment to the region also resulted in improved cooperation within the Minsk Group to deal with the Karabagh issue when the United States and France joined Russia as co-chairs in 1997. The group submitted different proposals for the Karabagh conflict after the United States and France became co-chairs.

\footnotetext{
577 Stephen Kinzer, “Azerbaijan Has Reason to Swagger: Oil Deposit,” The New York Times, 14 September 1997, p. 12.

${ }^{578}$ Arif Useynov, "Pipeline Routes Run Across Big-Time Politics. The Fight for Control of Oil Transportation Has Only Begun" and "Big-Time Politics' Seen Behind Caspian Oil Deal," Segodnya, 11 October 1995, p. 8, in FBIS-SOV-95-197, 12 October 1995, p.71; and Pashayev, 2006, p. 84..

${ }^{579}$ Edward Walker, "No War, No Peace in the Caucasus: Contested Sovereignty in Chechnya, Abkhazia, and Karabakh," in Crossroads and Conflict: Security and Foreign Policy in the Caucasus and Central Asia, Gary K. Bertsch, et al. eds., (New York: Routledge, 2000), p. 175.
} 
The OSCE Lisbon declaration is a successful example of the Azerbaijani lobby in the United States and the other western major powers. The United States primarily recognized the importance of the Karabagh issue because the issue is linked with the extraction and transportation of Caspian oil to the world market. As the United States Ambassador to Azerbaijan Richard Kauzlarich said "accessing Caspian oil deposits was more relevant for the West than that of solving the Karabagh conflict itself." 580

Another geopolitical issue for the United States was related with the transfer of Caspian oil to the world oil market. Before the start of the first Chechnya war in 1994, the multinational corporations participating in the Caspian consortiums regarded the Russian pipeline route as the priority one. ${ }^{581}$ However, the United States government preferred to have multiple pipeline systems to transfer Caspian oil through oil pipelines linking Azerbaijan with Russia and then through the Russian Black Sea ports of Novorossiysk and Tuapse as well as through the Baku- Tbilisi- Batumi- Poti oil pipeline and through a new pipeline from Georgia to Turkey's Mediterranean ports (the most important one is Baku-Tbilisi-Ceyhan). ${ }^{582}$ The American government had repeatedly insisted on the need for multiple options for the delivery of Azerbaijani oil to Western markets, with the Baku-Tbilisi-Ceyhan as the main oil pipeline. A few day before the session of the AIOC Steering Committee, at which this question was tackled, Clinton urged Aliyev and the international consortium to support the American proposal on the

\footnotetext{
${ }^{580}$ Arif Useynov: "The United States Is Interested in the Safe Transportation of Caspian Oil to the West, Because This Is Directly Related to the Protection of U.S. Investments in the Region" and "U.S. Envoy on Priorities in Caspian Oil Transport" Segodnya in 30 September 1995, p. 3., in FBIS-SOV-95-194, 6 October 1995, p. 71-72.

${ }^{581}$ LeVine, 2007, pp. 218-219.

582 Aleksey Chichkin: "Sentence to Oil Exports" and "Implications of Caspian Oil Route Examined", Rossiyskaya Gazeta, 21 October 1995 pp. 9-10 in FBIS-SOV-95-206, 25 October 1995, pp. 24-27.
} 
choice of these two routes (through Russia and Turkey), actually stressing that this might help to reduce political instability in the region. ${ }^{583}$

According to British Petroleum assessments, the oil resources in the Caspian region are one of the largest in the world: Total oil stocks there exceed 40-60 billion barrels of oil, or 4-6 percent of world proven recoverable oil reserves and 10-15 billion cubic meters gas, or 7-10 percent of world proven recoverable gas reserves, most of them around the Caspian sectors of Azerbaijan, Turkmenistan and Kazakhstan. ${ }^{584}$ These figures alone indicate how important the Caspian region's oil resources are for the main oil importers. On the pretext of protecting American interests, the Clinton Administration was openly opposing Russian claims in the Caspian basin and accused the Russian government of wanting to establish control over the Caucasus states and to control all the pipelines linking this region to the world oil market. Thus, in the second half of the 1990s American and Russian interests clashed in the Caucasus.

\section{Turkey}

Historically Russia and Turkey have long been competing for influence in the Caucasus. Azerbaijan, with its Turkish-speaking population, has been seen by Turkey as its stronghold in the Caucasus. Azerbaijan is also Turkey's geopolitical passageway to the five Turkic Central Asian republics that lie across the Caspian Sea into Central Asia. Turkey was the first to recognize Azerbaijan's independence. ${ }^{585}$ Moreover, both the

\footnotetext{
${ }^{583}$ Aleksandr Krasulin: "Where There's Whiff of Oil You're Bound to Find Americans: The United States Wants to See a Steady, Uninterrupted Supply of Azerbaijani Oil to Western Markets," and "Two-Pipeline Solution for Azerbaijan Oil 'Temporary," Rossiyskaya Gazeta, 14 October 1995, p. 15, in FBIS-SOV-95$\underline{199}, 16$ October 1995.

${ }^{584}$ John Roberts, "Energy Reserves, Pipelines Routes and the Legal Regime in the Caspian Sea," in The Security of the Caspian Sea Region, Gennady Chufrin, ed., (Oxford: Oxford University Press, 2001), p. 34.

${ }^{585}$ Dawisha and Parrott, 1994, p. 128.
} 
Azerbaijani political elites and public consider themselves part of the Turkish culture and even political system. Turkey thus established its prominent visibility in Azerbaijan, ranging from financial credits to supplying Latin alphabet books and other materials, to television programs. ${ }^{586}$

Two critical and closely interconnected political factors create a common approach between Azerbaijan and Turkey: the transportation of the Caspian oil and the conflict in Karabagh. In both cases the Azerbaijani and Turkish positions merge in a mirror reflection of the same principles. Turkey has firmly supported Azerbaijan in its conflict with Armenia over Karabagh. Turkish political elites believe that a peaceful settlement of the Karabagh conflict might assist in the resolution of Armenian-Turkish issues. Both Azerbaijan and Turkey also supported building a pipeline from Baku to Turkey's Mediterranean port, Ceyhan. These two countries' governments believed that this pipeline would be politically and economically beneficial to both Azerbaijan and Turkey. Thus, in these issues, Turkey and Azerbaijan shared mutual understandings and interests.

However, there was also an increasing recognition of the burdens among the Turkish ruling elite in Turkey that involvement in Azerbaijan could jeopardize Turkey's limited resources and interests in the Caucasus in the early 1990s. While Turkey sent military advisors to Baku, Turkey was unable to do anything substantively to aid Azerbaijan's war against the Armenian forces. Pressure from the United States and the other major western powers to Turkey prevented a significant Turkish military assistance to Azerbaijan because they were concerned about the Yeltsin's government struggling against the neo-nationalists in Russia. Moreover, signals from the United States to Turkey

${ }^{586}$ Suny, 1993, p. 214. 
were also discouraging the latter from becoming an active player in the Caucasus in the early 1990s. A Congressional Resolution on February 17, 1993, banning all except humanitarian aid to Azerbaijan in retaliation for the blockade of Armenia, seemed to put the United States government on one side of the conflict. ${ }^{587}$ Turkey was unable to do anything to stop the progress of the Armenian military forces, as the occupation of Kelbajar in the winter of 1992 illustrated most clearly.

Most importantly, the Turkish leadership became concerned about the prospect of Turkey's being on a collision course with Russia's attempt to recuperate its dominance in the region. Turkey's support for Azerbaijan and its threat of military intervention on Azerbaijan's behalf brought a sharp reaction by Marshal Shaposhnikov, Head of the Armed Forces of the CIS, and his warning of the "possibility of the Third World War."588 When Azerbaijan became independent, Turgut Ozal was the President and Suleyman Demirel was the Prime Minister of Turkey. Ozal welcomed the independence of Azerbaijan and the other Turkic states with great enthusiasm and he shifted from passive to active foreign policy. He wanted Turkey to act quickly to develop close relations with Turkic Republics because he believed that this was timely opportunity that might soon be lost. He also wanted to cooperate with the United States and the West and used Turkey as a bridge between the West and these countries. The death of Turkish President Ozal in April 1993 signalled the end of an active Turkish foreign policy in the Caucasus and Central Asia. The new Turkish President Demirel even signaled a softening

\footnotetext{
${ }^{587}$ Pashayev, 2006, p. 14.

${ }^{588}$ Idris Bal, Turkey's Relations with the West and the Turkic Republics: The Rise and Fall of the 'Turkish Model', (Aldershot: Ashgate, 2000), p. 94.
} 
of the rhetoric. ${ }^{589}$ For instance, Demirel pointed out that Turkey was trying to help solve the conflict between Azerbaijan and Armenia peacefully. Demirel pointed out that although Azerbaijan was in the right, any Turkish intervention might be considered provocative by the international community. He warned that "sentiment can be instrumental in solving problems, but I believe that only justice will lead to a solution." Demirel also warned that "if the United States and Western countries back Armenia in this conflict, then we will have to stand by Azerbaijan, and this will turn into a conflict between Muslims and Christians that will last for years. ${ }^{, 590} \mathrm{He}$ also expressed that "we are trying to bring the two neighboring countries closer together. Naturally,, it is impossible for us to accept any injustice inflicted on Azerbaijan. We will always react to this injustice. We have always said that the smallest pain Azerbaijan feels, we feel as well..591 Due to pressure from Russia and the United States combined with Demirel's cautious policy, Turkish assistance to Azerbaijan was limited. As a result, Turkey undermined the prestige of Elchibey. ${ }^{592}$ Thus, Turkey indicated its willingness to disengage its active foreign policy and to return to the pattern of the pacifist foreign policy toward Azerbaijan, especially after Russian declarations, including those by highranking members of the military, made it clear that Russia regarded the 'Near Abroad', the territory of the former USSR, as its zone of strategic interest.

\footnotetext{
${ }^{589}$ Bal, 2000, p. 52.

${ }^{590}$ Bal, 2000, pp. 94-95.

591 Tadeusz Swietochowski, “Azerbaijan’s Trianglar Relationship: The Land between Russia, Turkey and Iran,” pp.118-136, Ali Banuazizi and Myran Weiner, eds., The New Geopolitics of Central Asia and Its Borderlands, (Bloomington: Indiana University Press, 1994), p. 131.

${ }^{592}$ Yalcin Dogan, “Turkey Lost Azerbaijan,” Milliyet, 20 June 1993.
} 
Elchibey had sought above all to strengthen ties with Turkey. Not long after his election in June of 1992 as the president of Azerbaijan, Elchibey made his first official visit to Turkey. Elchibey's devotion to Ataturk and his model of a modern, secular state made the Azerbaijani leader popular among the Turkish elite and public. Indeed, among all the leaders of the Turkic-populated states that have emerged from the wreckage of the Soviet Union, none was so publicly pro-Turkish as Elchibey. Moreover, Elchibey's policy of rapprochement with Turkey, intended as a replacement with the long Russian presence, was pursued in an atmosphere of revived Pan-Turkish sentiments. ${ }^{593}$ Under Elchibey, Azerbaijan had withdrawn from the CIS, with Elchibey even saying that Azerbaijan had never seen itself as a member.

However, the Elchibey administration quickly became disappointed with the Turkish government. This disappointment was particularly high when, in the summer of 1993, the Armenians launched highly successful attacks against Azerbaijani positions in southern Azerbaijan. Throughout the winter of 1993, Turkey had opened its borders with Armenia to humanitarian aid, which provided Armenia with energy supplies, part of which seemed to have been used for military purposes. In the eyes of many Azerbaijanis, this dealt a strong blow to Turkish credibility and prestige. For example, Foreign Minister Tofik Kasymov called Ankara's decision to supply Armenia electricity “a stab in the back of Azerbaijan." Turkish officials hastily called off the deal and reassured the Azerbaijanis that "Azerbaijan has a priority position in Turkish foreign policy." 594

\footnotetext{
${ }^{593}$ Swietochowski, 1995, p. 192.

${ }^{594}$ Elizabeth Fuller, "The Thorny Path to an Armenian-Turkish Rapprochement," RFE/RL Research Report, 19 March 1993, 2, no. 12, p. 50.
} 
It is widely believed in Turkey that Elchibey's removal was engineered by Russia because of his strong anti-Russian views, his decision to withdraw from the Russian-led CIS and Russia's continuing interest in restoring its imperial domination over the Caucasus. ${ }^{595}$ Although Aliyev promised Turkish Foreign Minister Hikmet Cetin immediately after Elchibey's ouster that Turkey's relations with Azerbaijan would in no way suffer from the change of the Azerbaijan leadership, Aliyev signaled the end of the "special relationship" that Elchibey had cultivated with Turkey and set about improving ties with Russia and Iran. Moreover, the Aliyev administration moved quickly to suppress AFP's supporters. The government arrested several APF leaders and used force to break up street demonstrations. Aliyev consolidated his control. ${ }^{596}$ Aliyev also reversed some pro-Turkish decisions of Elchibey, hoping that Russia would take a more balanced stand in the Azerbaijan Armenian conflict. However, as Russian pressure mounted on Aliyev to accept the Russian military forces to Azerbaijan in the spring of 1994, Aliyev visited Turkey to restore relations and secure diplomatic support from Turkey.

The Turkish government cautiously approached Aliyev. A senior Turkish Foreign Ministry official said that "we recognize Elchibey as the legitimate president of Azerbaijan... But on the other hand, there is a practical problem. The Azerbaijan Meclis (Parliament) is a legitimate, constitutional organ of the country. Whether under duress or not, it has elected Haydar Aliyev as its leader... If Aliyev can bring stability to the country, that would be welcome." 597

\footnotetext{
${ }^{595}$ Yasin Aslan, "Soviet Game in Azerbaijan," Yeni Forum, July 1993, pp. 17-19.

${ }^{596}$ Elizabeth Fuller, “Iran and the Karabakh Mediation Process," RFE/RL Report, 25 February 1994, vol. 3, no. 8 , p. 31 .

${ }^{597}$ Daniel Sneider, "Big Power Rivalry in the Caucasus," Christian Science Monitor, 22 July 1993, p. 2.
} 
Later Turkish officials praised Aliyev for stabilizing and establishing order in the country. The Turkish President Suleyman Demiral stated that, "I don't think Haydar Aliyev can be blamed, because he was working with the former Communist regime. He is a man of experience and of wisdom." Demirel had a relationship with Aliyev going back 25 years. Unlike his predecessor, the late President Turgut Ozal, Demirel preferred the strong pragmatic style of Aliyev to the unrealistic idealism of Elchibey. Ozal was seen a visionary whereas Demirel had been seen a pragmatist in Turkey. ${ }^{598}$

During his visit to Turkey in 1997, Aliyev made a statement to the effect that the Azerbaijani government preferred the Turkish option for transporting Azerbaijani Caspian oil over the Russian one. The initial agreement on the Russian route via Grozny became threatened by the war in Chechnya. Despite the preliminary agreement under which "early" oil from the Caspian shores was supposed to begin flowing along the Baku-Grozny-Novorossiysk route, Aliyev signed a declaration on strategic partnership between Azerbaijan and Turkey and made a declaration that he preferred the BakuTbilisi-Ceyhan oil route to the world oil market. In his visit, Aliyev also urged the Turkish military to extend their protection to pipeline security in the Caucasus. ${ }^{599}$ Moreover, during the Turkish Prime Minister, Tansu Ciller's visit to Baku, Aliyev proposed that Turkey assume authority over the Nakhichevan Autonomous Republic. Under both the Treaties of Kars and Moscow in 1921, Turkey was considered a guarantor for Nakhichevan along with Russia. Aliyev cited difficulties that Azerbaijan faced in its

\footnotetext{
${ }^{598}$ Sneider, 1993, p. 2; and Elizabeth Fuller, “Azerbaijan at the Crossroads," in Challenges for the Former Soviet South, Roy Allison, ed., (Washington, D.C.: Brookings Institution Press, 1996), p. 133.

${ }^{599}$ Yelena Oyliyeya: "Aliyev Promises Caspian Oil to Ankara. Absence of Peace Treaty with Chechnya Cuts Russian Oil Route," Kommersant-Daily, 7 May 1997, p. 2; and Roy Allison, "The Military and Political Security Landscape in Russia and the South," in Russia, the Caucasus, and Central Asia: The $21^{\text {st }}$ Century Security Arrangement, Rajan Menon, et al., eds., (Armonk: M.E. Sharpe, 1999), p. 36.
} 
ties with Nakhichevan due to a blockade by Armenia. Thus, these are clear indicators of the vital development of Azerbaijan's relations with Turkey at all levels. ${ }^{600}$

The course of the political consultations indicates that relations between the two countries were indeed at a high level in the second half of 1990s. Turkey had firmly supported and continued to support Azerbaijan in its conflict with Armenia over Karabagh. Turkey became active in the region and contributed to peaceful settlements, including efforts within the framework of the OSCE, for regional conflicts. The Turkish governments believed that a stable and peaceful Caucasus would open up opportunities for Turkey. Thus, Azerbaijan's relations with Turkey remained strong because of the two countries' shared history, ethno-national origins, geographic proximity and mutual interests in the region.

\section{Iran}

The relations of Azerbaijan with Iran might not have looked problematic at first glance but there were potential problems. First, Azerbaijan is a secular state; while Iran is a religious state. Iran can destabilize the political situation in Azerbaijan because of the same religious background. Secondly, Iran enjoys strong economic ties with the Caucasus states, especially with Armenia. Iran is one of Armenian's biggest economic partners. Thirdly, approximately 20 million Azeri people live in Iran, more than the twice population of Azerbaijan itself.

Fourthly, Iran is the country that shares the longest border with Azerbaijan, which is about $600 \mathrm{~km}$ long. Two regional powers, Iran and Turkey, who have borders with the Caucasus states, were keen to offer themselves as political and military models

\footnotetext{
${ }^{600}$ Dimitry Aliev end Georgy Bovt, "Turkish Prime Minister's Foreign Tour: Given the Political Will," Kommersant, 12 July 1995, in The Current Digest of Post-Soviet Press, 1995 vol. XLVII, no. 28, p. 4.
} 
immediately after independence. ${ }^{601}$ Fifthly, Azerbaijan found itself between Iran and the United States. If the United States prompts harsher means towards Iran over its desire to have nuclear technology, Azerbaijan political elites believe that Azerbaijan is one of the first states pushed by the United States to show its discontent with Iran.

Elchibey had been making statements about the two Azerbaijan and Azerbaijani (Turks) in the following mood: "The twenty million Turks living in South Azerbaijan do not even have one school. Iran's attempt to help us is not very convincing especially when you consider that they deny the most basic rights to people living on their territory. ${ }^{\prime 602}$ The Iranian government protested Elchibey's statement and considered him as a threat to Iranian territorial unity. In addition to that, Iran supplied economic assistance to Armenia at a time when the Iranian government was trying to undermine the Elchibey government. The Iranian government remained concerned over southern Azerbaijan (or Iranian Azerbaijan). The government considered Turkey behind Elchibey's regime and the U.S. behind Turkey.

By contrast, after Aliyev came to power, Azerbaijani-Iranian relations began to improve. Aliyev himself was inclined to improve relations with Iran. He believed that better relations with Iran would help in the favorable resolution of the Karabagh problem. Therefore, during the first year of Aliyev's presidency, there was some warming up of Azerbaijani-Iranian relations. Aliyev visited Iran in summer 1994 and assured the Iranian leadership that Azerbaijan had no claims on Iranian Azerbaijan. For his part, Aliyev

\footnotetext{
${ }^{601}$ Philip Petersen, "Security Policy in Post-Soviet Transcaucasia", European Security, Spring 1994, vol. 3, no. 1, pp. 43-44.

${ }^{602}$ Turkiye, 28 May 1992, p. 13, in FBIS-SOV-92-108.
} 
promoted warm relations between Azerbaijan and Iran. ${ }^{603}$ However, the United States' opposition to a significant role for Iran in the region and Azerbaijan's desire to develop close economic and political relations with the West had a strong influence in determining the state of Iranian-Azerbaijan relations. To illustrate, Azerbaijan was forced to withdraw its offer of a 10 percent share for Iran in the international consortium to develop part of its oil fields because of the U.S. opposition. ${ }^{604}$

\section{4e. Conclusion}

Azerbaijan's foreign policy had been shaped by the strong political orientations of its first two leaders, in the case of Mutalibov, a strong pro-Russian orientation, and in the case of Elchibey, a strong pro-Turkish orientation in the early 1990s. On the other hand, Azerbaijan's third president, Aliyev's foreign policy was more pragmatic and shifted based on both the personal and national interests. Therefore, the personal orientation of its leaders significantly affected the foreign policy orientation of Azerbaijan.

Moreover, there was several other factors influenced Azerbaijan's foreign policy.

First, its oil reserves attracted international interest to the country in the second half of 1990s. Azerbaijan's hydrocarbon reserves turned out to be the most essential factor in Azerbaijan's relations to the outside world. Second, its close ties to Turkey have allowed Azerbaijan to alternate Russia with another regional power. Third, the Karabagh issue was also one of the most significant foreign policy issues of the different Azerbaijani governments.

\footnotetext{
${ }^{603}$ Mamed Safarly, "Teheran and Baku: Conflicts against Backdrop of Good-Neighbor Relations," Nezavisimaya Gazeta, 5 July 1994, p. 1, in The Current Digest of the Post-Soviet Press, 3 August 1994, vol. XLVI, no. 27, pp. 21-22.

${ }^{604}$ Hunter, 2000, p. 42.
} 
The Karabagh issue was not only an indicator for Azerbaijani foreign policy but also a platform for a bid for power in the country during the 1990s. For instance, the first three presidents of Azerbaijan started their presidency with attempts to make military progress in Karabagh. The first two of them (Mutalibov and Elchibey) lost their presidential positions. The third, Aliyev, accepted a cease-fire. Moreover, the Karabagh issue also affected Azerbaijani-Russian relations. The Russian involvement had played an important role, such as the manipulation of divisions by competing Azerbaijani political elites, and indirectly supporting the Armenian side in Karabagh.

Mutalibov, like most former Communist Party leaders who became presidents of their newly independent states, sought to keep the old governing system and relied on Russian support. He believed that the only way to stay in power was to have support of the old center, Moscow, and old ruling elites, i.e., the Communist nomeklatura. ${ }^{605}$ Mutalibov was attached to Russia because he owed his position to the Russian involvement in Azerbaijani domestic politics, especially after the 'Black January' in 1990. Therefore, from the beginning of his presidency, Mutalibov was handicapped by the fact that he had come to power in the shadow of the Russian forces. He needed Russian assistance to deal with domestic opponents. Therefore, his foreign policy was totally oriented to Russia. He supported the Moscow coup in 1991 and favored signing the CIS founding documents. Mutalibov, under the pressure of internal opposition and weakness of state institution, omnibalanced with Russia to deal with internal challengers to his leadership. He was ousted by the parliament in the wake of the massacre of

${ }^{605}$ Altstadt, 1992, pp. 221-222. 
refugees fleeing Khojaly, a town the Armenian forces had taken with the help of the $366^{\text {th }}$ Russian Regiment stationed in Karabagh in March 1992.

The second president of Azerbaijan, Elchibey was characteristic of the first generation of leaders of the post-Soviet states in the former Soviet Union, many of whom were nationalist and idealist former dissidents. He brought a different set of political orientations to Azerbaijani foreign policy. First, Elchibey's foreign policy was based on anti-imperialism in order to oppose internal political groups and elites who received political support from Russia. Elchibey thus looked for external asistance to balance against Russia who threatened the Elchibey regime. He considered Azerbaijan's future as being tied closely with that of Turkey and the West. Therefore, he believed that having strategic relations with Turkey and the West made a significant step from the point of view of Azerbaijan's interests. As a result, Elchibey distanced Azerbaijan from Russia and during his presidency Russian influence appeared very much on the decline, on the other hand Azerbaijan-Turkish relations soared.

Asking Russian military forces to leave the country, a readiness to sign oil and gas agreement with Western oil corporations without including Russian and Iranian ones, and Elchibey's intention of uniting South or Iranian Azerbaijan with the independent Azerbaijan alienated him from Russia and Iran. However, the result of Elchibey's foreign policies was isolation and ultimately Elchibey was overthrown by Russian supported Huseyinov's forces. Elchibey's removal was engineered by Russia because of his strong anti-Russian views, his decision to withdraw from the Russian-led CIS and Russia's continuing interest in restoring its imperial domination over the Caucasus as well as Elchibey's pro-Turkish policies. 
Elchibey departure from the political scene and his replacement by Aliyev prompted expectations that there would be a substantial shift in Azerbaijani's foreign policy towards Russia. Aliyev, as a long-time member of the Communist nomenklatura, was particularly aware of the length and power of Moscow's reach in the former Soviet land. As a pragmatic and self-oriented leader, Aliyev was aware of the weakness of Azerbaijan and believed that Azerbaijan could not manage without Russia. Therefore, Aliyev omnibalanced with Russia against domestic challengers to his power. The first two years of Aliyev administration could be considered as pro-Russian based on his policies. Aliyev hoped that if he shifted Azerbaijani foreign policy orientation to Russia, Russia would take a more balanced stand in the Azerbaijan-Armenian conflict and support his regime. He canceled Elchibey's plan for the oil and pipeline deal. Aliyev took back Azerbaijan into the CIS in October 1993, and the Russian oil company Lukoil was brought into the Azerbaijani consortium being granted rights to exploit Azerbaijani oil. Russian mediated a ceasefire between Armenian and Azerbaijani forces over Karabagh in 1994. ${ }^{606}$ Thus, the theory of omnibalancing allows for greater explanatory power in Aliyev' foreign policy orientation in the early 1990s.

After eliminating his opponents, such as Huseyinov and Guliyev, and securing his position as the leader of the country, Aliyev began to refuse to accept the Russian demands. For instance, Aliyev resisted Russian demands to maintain Russian peace keeping forces in Karabagh. He also refused a permanent Russian military presence in Azerbaijan. ${ }^{607}$ However he was aware that such denials entailed risks. Therefore, Aliyev

\footnotetext{
${ }^{606}$ Waal, 2003, p. 226, and pp. 253-254.

${ }^{607}$ Nuriyev, 2000, p. 143.
} 
promised to lease the Gabala radar station to Russia. But he visited Turkey in spring 1994 to restore good relations and secure Turkish diplomatic support to his foreign policy. In addition, Azerbaijan became a member of NATO’s PfP program in 1994. So, Aliyev returned to more or less the same policy towards Russia as that of Elchibey.

Aliyev also skillfully played the oil card game to apply pressure on Russia and attract major western powers. The Azerbaijani oil reserve was used as a carrot, promises of the pipeline pass through Russia, and a stick, threats to lay the pipeline bypassing Russian territory. Aliyev also moved with determination to attract western oil corporations to develop the Azerbaijani sector of the Caspian Sea. Aliyev recognized that the major western powers' care about oil reserves of Azerbaijan. Therefore, as a selfinterested and experienced politician, Aliyev successfully played the oil card for his personal interests. He first moved to resolve the oil question, signing the "contract of the century" with western oil companies after giving Russia's Lukoil a ten percent interest in the consortium. As a result, he secured the support of the Western major powers for his regime. Thus, he was noticeably more pragmatic than the first two leaders of Azerbaijan in dealing with Russia; Aliyev sought to balance Russian influence by strengthening his internal position as well as external position by increasing his relations with other major powers.

Aliyev accused Russia of supporting the attempted coup d'etat against his leadership in 1994. He portrayed a direct link between the attempted coup and the signing of the oil contract; he implied that Russia was responsible ultimately for the coup due to his support of the oil deal and his continuing refusal to accept Russian troops in the 
country. Thus, Aliyev secured his position as the leader of the country and strengthened his leadership with the oil deal against potential internal and external threats.

Aliyev led to a shift in Azerbaijan's orientation away from Russia and toward closer cooperation with the West. Thus, by at the end of 1994, Azerbaijan had joined NATO's Partnership for Peace Program, established close ties with the EU, and became a member of GUAM ${ }^{608}$ Moreover, despite the preliminary agreement under which early oil from the Azerbaijani Caspian shores was supposed to begin to flow along the BakuGrozny-Novorossiysk route as early as 1998, Aliyev began to talk about an alternative route through Turkey. He declared that Azerbaijan prefered the Turkish option for transporting oil over the Russian one. Having oil reserves produced exceptional financial power that transformed the position of Azerbaijan vis-à-vis Russia and western major powers from dependence into asymmetric interdependence.

\section{Georgia}

\section{5a. Foreign Policy Making Process}

Some students of the Caucasus divide the development of Georgia's foreign policy in the 1990s into two main periods- the presidency of Gamsakhurdia, from the announcement of independence until December 1992, and the presidency of Shevardnadze from 1992 to $1999 .{ }^{609}$ However, according to the foreign policy orientation of Georgia, Georgian foreign policy can be divided into three different periods: the confusing foreign policy of Gamsakhurdia from independence to 1992; the dependent

\footnotetext{
${ }^{608}$ Hunter, 2000, p. 42.

${ }^{609}$ Hunter, 2000, pp. 98-99; Herzig, 1999, pp. 98-99; and David Darchiashvili, Georgia: The Search for State Security, Caucasus Working Papers (Stanford: Center for International Security and Cooperation, Stanford University, 1997), pp. 2-3.
} 
foreign policy of Shevardnadze to Russia from 1992 to the end of 1994; and the western oriented foreign policy of Shevardnadze after 1994. In the first period, as the consequence of Gamsakhurdia's nationalist and anti-Russian foreign policy, Georgia alienated Russia and the Western powers ignored Georgia because of its Russian-oriented Caucasus policies. In the second period, as a result of severe domestic conflicts and external pressures, such as the Russian pressure on the Georgian government, Georgia's foreign policy was reactive and short-term oriented. In the third period, Georgia managed to achieve political domestic stability and gain enough political experience and have alternatives to enable Georgia to have a more active foreign policy and be more determined in carrying out a pro-Western foreign policy. ${ }^{610}$ Thus, Georgia was confronted in the first half of the 1990s with the issue of survival and security and in the latter part of the decade with the choice of foreign policy orientation.

There were several factors that influenced the Georgian foreign policy process. The four most important factors in the first half of the 1990s were: Gamsakhurdia's nationalist legacy, the fragmentation of Georgia, Shevardnadze's personality, and Russian involvement in Georgian domestic politics. ${ }^{611}$

Georgia declared independence in April 1991 and Gamsakhurdia was elected as the first president of the country. Gamsakhurdia identified Georgia with the western world. He attempted to leave the "Soviet" past behind and become part of the "West", distancing Georgia as much as possible from Russia. The Western powers, however,

\footnotetext{
${ }^{610}$ Alexander Rondeli, "The Choice of Independent Georgia," in The Security of the Caspian Sea Region, Gennady Chufrin, ed., (Oxford: Oxford University Press, 2001), p. 202.

${ }^{611}$ Stephen F. Jones, “Georgia's Power Structures,” RFE/RL Research Report, 1 October 1993, vol. 2, no. 39.
} 
refused to recognize the country's independence. Moreover, in the first year of independence (1991-1992) the domestic political environment had become increasingly nationalized and radicalized, and a governmental crisis emerged. Gamsakhurdia and his government had manage to isolate themselves from the international community.

In Georgia, violent confrontations with non-Georgian minorities in the autonomous republics of Abkhazia and South Ossetia threatened to accelerate the complex process of fragmentation in the country. In the autumn of 1991 Gamsakhurdia moved to abolish the autonomous status of the South Ossetian Autonomous Republic, and the Ossetian conflict gained further momentum in the first half of 1992, forcing large numbers of South Ossetians to flee to Russian North Ossetia. This danger of Georgia fragmenting increased and provided an excuse Russia to get involved in the domestic politics of Georgia. Gamsakhurdia was ousted by coup d'etat, followed by episodes of a civil war between the Zviadists and a new government led by Shevardnadze. ${ }^{612}$

The first half of the 1990s for Georgia was chaotic. There were five elections, a coup d'etat, civil war between different political groups, the rise of lawlessness and uncontrolled paramilitary groups as well two ethnic-territorial wars between the central government and separatist regions of Abkhazia and South Ossetia, which ended with the victory of the latter, and the establishment of de facto independent states. This political turmoil was accompanied by a nearly complete economic collapse. ${ }^{613}$ Therefore, Georgia emerged as a small and weak state torn apart by internal fighting among political elites

\footnotetext{
${ }^{612}$ Maxim Shashenkov, "Russia in the Caucasus: Interests, Threats and Policy Options," in Russia and Europe: The Emerging Security Agenda, Vladimir Baranovsky, ed., (Oxford: Oxford University Press, 1997), p. 429.

${ }^{613}$ Ghia Nodia, "Dynamics of State-Building in Georgia," Demokratiatsiya, Winter 1998, vol. 6, no. 1, pp. 6-13 and Ghia Nodia, 2000, p. 188.
} 
and two ethnic conflicts as well as economic problems. These factors defined Georgia's strategic orientation and foreign policy priorities. ${ }^{614}$

Georgia's foreign relations were seriously blocked by these conflicts. Firstly, a civil war for controlling the state took place between the supporters and opponents of Gamsakhurdia, and the return of Shevardnadze as Georgia's leader in March 1992 was the result of a coup by anti-Gamsakhurdia forces. The second conflict was between nationalist forces in South Ossetia and the Georgian government in Tbilisi. A ceasefire was agreed upon between Russia, South Ossetia and Georgia in July 1992, and was policed by forces from Russia, Georgia and both South Ossetia and the Russian republic of North Ossetia. ${ }^{615}$ The third conflict is the war in Abkhazia between the Abkhazian separatists and the Georgian government.

After Shevardnadze's return to Georgia, Georgia was recognized by the international community and began to establish diplomatic relations with other states. In 1992 Georgia joined the United Nations, CSCE, and several other international organizations. Although Shevardnadze was trying to have an active foreign policy during 1992-1994, Georgia’s foreign policy was largely determined by the domestic political situation. $^{616}$

Abkhazians and South Ossetians see Russia as their protector and Georgia has found itself facing a potential conflict with Russia because of Russian involvement in the

\footnotetext{
${ }^{614}$ Rondeli, 2001, p. 195.

${ }^{615}$ Christopher Zurcher, "Georgia's Time of Troubles, 1989-1993," in Statehood and Security: Georgia after the Rose Revolution, Bruno Coppieters and Robert Legvold, eds., (Cambridge: The MIT Press, 2003), p. 94.

${ }^{616}$ Jonathan Aves, "The Caucasus States: The Regional Security Complex," Security Dilemmas in Russia and Eurasia, Roy Allison and C. Bluth, eds., (London: Royal Institute of International Affairs, 1998), p. 176.
} 
Abkhazian and South Ossetian conflicts. The Abkhazian war in particular has been the most prolonged and has seriously strained relations between Russia and Georgia, as Georgia accused Russia of supporting Abkhazian forces in 1992 and 1993. ${ }^{617}$ The result was the defeat of the Georgian military forces against the separatists. Moreover, war against the Russian-support Abkhazian separatists in Abkhazia left the Georgian government vulnerable in the face of an offensive by supporters of Gamsakhurdia in western Georgia.

This condition forced Shevardnadze to make significant changes in Georgian foreign policy. He sought to develop a close relationship with Russia in order to end Russian support to the Abkhazian separatists. Faced with the collapse of Georgia in September 1993, Shevardnadze openly expressed that "we have to cooperate with Russia ... otherwise Georgia will collapse and disintegrate." This effectively brought Georgia back into the Russian sphere of influence. ${ }^{618}$ Therefore, because the major Western powers did not balance in any significant way against Russia's action, the Georgian government had been forced to bandwagon. Indeed, given the Russian military support to separatists in both the Ossetian and Abkhazian conflicts, as well as Georgia's own economic dependence on Russia, the Georgian government did not have much option other than to accept what Shevardnadze termed a "reserved policy" toward Russia. ${ }^{619}$

\footnotetext{
${ }^{617}$ Dov Lynch, The Conflict in Abkhazia: Dilemmas in Russian 'Peacekeeping' Policy, (London: The Royal Institute of International Affairs, 1998), p. 26.

${ }^{618}$ Lynch, 1998, p. 28.

${ }^{619}$ Dawish and Parrott, 1994, p. 225.
} 
Georgia joined the CIS and signed an agreement allowing Russian military bases to remain on Georgian territory for 25 years. ${ }^{620}$ In 1994 Georgia and Russia signed a bilateral agreement on friendship and cooperation, which was ratified only by the Georgian Parliament: the Russian Duma has yet to ratify an already outdated document. ${ }^{621}$ Moreover, In 1995 Georgia and Russia signed another treaty on Russia’s military presence in Georgia, again agreed for 25 years. Ratification of this agreement by Georgia was conditional on Russia's support for Georgia's territorial integrity and the build-up of its military power. ${ }^{622}$

In the second half of the 1990s, Georgia pursued internal reforms and established constitutional law and order (a new constitution was adopted in August 1995). The Shevardnadze government also eliminated all paramilitary groups and secured his leadership. This internal cohesion and stability also affected the foreign policy orientation of the Georgian state.

Georgia's foreign policy was largely determined by two main circumstances during the second half of the 1990s. One was the tension between Russia and Georgia, and Georgia's desire to diminish its dependence on Russia, which limits its ability to have an independent foreign policy. The second was increased political and military cooperation with the United States and NATO as well as integration with Europe. Therefore, in the second half of the 1990s the Georgian government oriented Georgian foreign policy toward the West. The government also saw participation in Caspian Sea

\footnotetext{
${ }^{620}$ Kortunov, A. "Russia, the Near Abroad and the West," in The New Russia: Troubled Transformation, G. Lapidus, ed., (Boulder: Westview Press, 1995), pp. 172-173.

${ }^{621}$ Rondeli, 2001, pp. 197-198.

${ }^{622}$ Rondeli, 2001, p. 198.
} 
energy projects and transport corridors as decisive for Georgian foreign policy objectives. $^{623}$.

In 1994 Georgia joined the NATO PfP programme, which marked the beginning of its relations with NATO. In the same time year Shevardnadze paid an official visit to the United States and established initial contacts with the IMF and the World Bank. Moreover, David Tevzadze, a West Point graduate, replaced Vardiko Nadibaidze, a career Soviet army officer, as Georgian defense minister in 1998. Bilateral defense cooperation between Georgia and the United States increased after Tevzadze's appointment. $^{624}$

GUAM, which included Georgia, Ukraine, Azerbaijan and Moldova, was created, as a special interstate consultative body in Vienna in 1996. GUAM member states emphasized that the purpose of their organization was to provide a forum for consultation, rather than to organize a bloc or alliance against any country; however, it is clear to see that a central goal of GUAM members is to achieve greater independence from Russia. The reason is that all these countries had similar problems with Russia and decided to hold consultation on a regular basis in order to coordinate their policies. Russia’s attitude towards GUAM has not surprisingly been negative. ${ }^{625}$

The Georgian government also noticed the opportunities that could be brought by the creation of a 'transportation corridor', which may include the 'main oil' pipeline

\footnotetext{
${ }^{623}$ Ivlian Haindrava, "Letter from Georgia: Looking Beyond Shevardnadze," Problems of PostCommunism, January/February 2003, vol.50, no.1, pp.22-23.

${ }^{624}$ Scott A. Jones, "Turkish Strategic Interests in the Transacaucasus," in Crossroads and Conflict: Security and Foreign Policy in the Caucasus and Central Asia, Gary K. Bertsch, et al., eds., (New York: Routledge, 2000), p. 58.

${ }^{625}$ Rondeli, 2001, p. 198 and Yunusov, 1999, p. 165. Officially, GUAM was founded at the Council of Europe meeting in October 1997 in Strasbourg.
} 
carrying crude from the Caspian drilling fields to the Black Sea as well as Western goods to the Caucasus and Central Asia via a new 'silk road'. Shevardnadze at firstly lobbied for the renovation of the Baku-Batumi pipeline to carry "early oil" from the Caspian fields. He met with Clinton and Aliyev as well the chairman of the AIOC. ${ }^{626}$ The pipeline issue was not just a question of huge amounts of financial sources for Georgia but also an issue of Georgian relations with Russia that provided an opportunity for Georgia to decrease its dependence on Russia and develope close relations with western powers. ${ }^{627}$ In November 1999, at the OSCE summit meeting in Istanbul, Georgia, Azerbaijan and Turkey signed an agreement on the Baku-Tbilisi-Ceyhan pipeline route for the export of oil from the Caspian region.

The year 1999 was also marked by significant foreign policy decisions. Georgia joined the Council of Europe and the WTO and withdrew from the 1992 Treaty on Collective Security. ${ }^{628}$ Russia agreed to start its withdrawal from its military bases in Georgia in 2000. By the end of 1999 all Russian border guards had left Georgia and were being replaced by Georgian guards. Furthermore, in 1999 Georgia joined NATO’s Program Analysis and Review Process (PARP), which helped the upgrading of the Georgian military forces to NATO standards and the participation of Georgian military forces in peacekeeping operations. For the first time a Georgian unit joined the NATO peacekeepers in Kosovo. ${ }^{629}$

\footnotetext{
${ }^{626}$ See LeVine, 2007, pp. 24-26. There was a pipeline from Baku to Batumi built at the beginning of the $20^{\text {th }}$ century.

${ }^{627}$ Elmar Guseinov, “Will The Oil Pipeline Go Through Georgia?” Izvestia, 14 February 1998, p.2, in The Current Digest of the Soviet Press, 1998, vol. 50, no.7, p. 17.

628 “Baku-Ceyhan Oil Agreements Signed in Istanbul," FBIS-SOV-1999-118, 18 November 1999.

${ }^{629}$ Rondeli, 2001, pp. 198-199.
} 
According to Article 48 and 69 of the Georgian Constitution, the President and Parliament are responsible for exercising and defining the country's foreign policy. ${ }^{630}$ The Ministry of Foreign Affairs and the State Chancellery are responsible for carrying out the policy.

The three state institutions involved in the foreign policy process in Georgia are: The President's office, the Ministry of Foreign Affairs, and Parliament. Georgia is governed by a presidential system. Georgia, like the other Caucasus states, faced problems in establishing a Ministry of Foreign Affairs. These problems included finding experienced diplomats, financing the ministry, and establishing and staffing embassies abroad. During the first year of independence, the international community ignored Georgia. After Shevardnadze became head of the state, however, major western powers opened embassies and high level visitors came to Tbilisi, such as U.S. Secretary of State, James Baker, and Hans-Dietrich Genscher, Foreign Minister of Germany. ${ }^{631}$ Full diplomatic relations, including mutual exchanges of missions, were first established with the United States, Russia, and Turkey.

When Gamsakhurdia was the president of Georgia, the Prime Minister Tengiz Sigua and Foreign Minister Georgi Khoshtaria were also actively participating in the making of foreign policy. However, Sigua resigned and Khoshtaria was dismissed by Gamsakhurdia because of Gamsakhurdia's disappointment of Khoshtaria's inability to arrange a meeting for Gamsakhurdia with the United States President George H. Bush during Bush's visit to Moscow. Both Sigua and Khoshtaria accused Gamsakhurdia of

\footnotetext{
630 "The Constitution of Georgia," http://www.mfa.gov.ge/files/37_57_318646_constitutiont.pdf, p. 18 and p. 11 .

${ }^{631}$ Goltz, 2006, pp. 85-86.
} 
being a dictator and 'modeling after Albania'. ${ }^{632}$ Murman Omanidze was replaced and served as foreign minister until Gamsakhurdia was overthrown. Because of the chaos and civil war in Georgia, countries were reluctant to recognize or establish diplomatic relations with the Gamsakhurdia's government. In any event, Gamsakhurdia had the last word on all important foreign policy decisions. ${ }^{633}$

After Shevardnadze came to power, he shared his decision-making authority with other members of State Council, Kitovani, and Sigua as well as Ioseliani. After the October 1992 election, Shevardnadze appointed Kitovani as defense minister, Temur Khachishvili (a close association of Ioseliani) as minister of internal affairs and Alexandre Chikvaidze, a former Soviet ambassador to the Netherlands, as minister of foreign affairs. ${ }^{634} \mathrm{He}$ also appointed Ioseliani as representative of the Georgian side to negotiate for the Abkhazian conflict in Geneva. Later, when he fully controlled the political situation, he got rid of them one by one. He dominated the political scene, with no minister or pro-government parliamentarian having a strong independent political profile or power base in the second half of the 1990s. He hired new ministers who were loyal to him such as Irakli Menagarishvili who was foreign affairs minister from 1995 to 2003 and Tedo Japaridze, who served as ambassador to the United States and later chair of the National Security Council. As a result, Shevardnadze played a special and decisive

\footnotetext{
${ }^{632}$ Elizabeth Fuller, "The Transcaucassus: Real Independence Remains Elusive,” RFE/RL Research Report, 3 January 1992, vol. 1, no. 1, p. 50; and "Georgia Opponents Charge Republic Is Led by Dictator," New York Times, 6 September 1991.

${ }^{633}$ James P. Nichol, Diplomacy in the Former Soviet Republics, (Westport: Praeger, 1995), pp. 142-143.

${ }^{634}$ Jonathan Aves, Post-Soviet Transcaucasia, (London: Royal Institute of International Affairs, 1993), p. 43.
} 
role in foreign policy because of his experience and international recognition and reputation. He was the ultimate decision-maker. ${ }^{635}$

The Ministry of Foreign Affairs coordinates inter-agency efforts. To foster better coordination the ministry holds regular consultations with other relevant agencies and involves them in the decision-making process. Another state institution working on foreign policy issues is the National Security Council, set up in 1996 and headed by the president. It has responsibility to prepare strategic concepts, develop foreign policy strategy, inter-agency conflicts and then present final draft documents to the president. This organization has been very successful in reducing inter-agency conflicts and disagreements. However, there have also been clear cases of failure in strategic planning. One example is the resolution on 'Basic Principles of the Sustainability of Social Life, the Strengthening of State Sovereignty and Security, and Restoration of the Territorial Integrity of Georgia," passed by the parliament in April 1997. This document was an incomplete draft of Georgia's foreign policy strategy. Its tone was not consistent with the actual foreign policy conducted by the Georgian government. ${ }^{636}$

In the early 1990s, the Georgian government totally relied on intuition and Shevardnadze's personal insight in determining foreign policy and national security priorities. After the 1995 elections, the Georgian Parliament led by Zurab Zhvania became active not only in domestic politics but also foreign policy-making processes. Zhvania was first secretary of the CUG, the ruling party. After the election 1995, he became the speaker of the Parliament. Shevardnadze and Zhvania built their own power bases, Shevardnadze in the executive branch of the government, Zhvania in the

\footnotetext{
${ }^{635}$ Rondeli, 2001, p. 200.

${ }^{636}$ Rondeli, 2001, p. 200.
} 
Parliament. While, Zhvania's power base was still subordinate to and dependent on Shevardnadze's, Zhvania nevertheless consolidated his power. He actively advocated and became the driving force towards making Georgia a part of the European system. He thus recruited young, western-educated and pro-western figures, like Mikhail Saakashvili and Davit Onoprishvili. ${ }^{637}$

In the second half of the 1990s, the Georgian parliament became more active in the foreign policy sphere. The document "About Conceptual Issues of Foreign Policy" was prepared by the Parliamentary Foreign Relations Committee. It is distinguished by the analysis of the interests of neighboring states, and makes an attempt from this analysis to chart a general course for Georgian foreign policy. Its main conclusion is that a balance must be struck between the interests of regional powers, in the process incorporating areas of common Caucasus cooperation and building closer contacts with the west. ${ }^{638}$ Therefore, the Georgian Parliament was a more effective and active institution than those in Armenia and Azerbaijan.

Shevardnadze declared in his State of the Union address in 1997 that joining Europe 'was for centuries the dream of our ancestors'. In a speech of January 1999, Menagarishvili emphasized that the first priority of Georgia's foreign policy was European integration. Zhvania also declared in his speech of accession to the Council of Europe in February 1999, 'I am Georgian, therefore I am European.' 639

\footnotetext{
${ }^{637}$ Wheatley, 2005, p. 89.

${ }^{638}$ David Darchiashvili, "Trend of Strategic Thinking in Georgia," in Crossroads and Conflict: Security and Foreign Policy in the Caucasus and Central Asia, Gary K. Bertsch, et al., eds., (New York: Routledge, 2000), pp. 69-70.

${ }^{639}$ Rondeli, 2001, p. 208.
} 
In conclusion, Georgia had only been able to focus on its survival and immediate concerns, such as the conflict in South Ossetia and Abkhazia, and internal instability, rather than on choice of foreign policy orientation in the early 1990s. But since late 1994, Georgia managed to develop a more active foreign policy. Despite the unsettled conflicts in Abkhazia and South Ossetia and the issue of the Russian military bases, Georgia's foreign policy became strongly Western-oriented, with the goal of final integration into the European community. This tendency became more and more obvious during the late 1990s and after. ${ }^{640}$

\section{5b. Leadership Perception on Foreign Policy}

\section{Zviad Gamsakhurdia (1991-1992)}

After the declaration of independence in April 1991 and the election of Gamsakhurdia as president, the Georgian government began to seek international recognition and legitimacy for Georgia and tried to establish links with other countries. There were numerous unofficial visits and consultations during Gamsakhurdia's tenure. Gamsakhurdia's foreign policy can be characterized by an idealistic understanding of the international environment and were full of slogans and what could be called wishful strategic thinking. ${ }^{641}$ There are several reasons for this. First, Gamsakhurdia had unrealistic expectations that the western world would embrace Georgia. He and his colleagues thought that Georgia in particular and the Caucasus in general would serve as a buffer zone between the East and West. Therefore, they considered the 'bufferization'

\footnotetext{
${ }^{640}$ Rondeli, 2001, p. 201.

${ }^{641}$ Rondeli, 2001, p. 201.
} 
of Georgia as an ideal strategic move which would attract the Western support. ${ }^{642}$

Gamsakhurdia's policies, however, were rejected by the West. Second, because of their intense nationalism, reinforced by the traumatic experience of 1989 , these elites induced major changes in popular and elite expectations of both domestic and foreign policy. They were fiercely anti-Communist and anti-Russian, and believed that they held the moral high ground. The Georgian government was trying to separate itself from Russia. There were attempts to bring the Chechens, Abkhazians and Georgians under a common Caucasus home and an alliance against Russian interference in the Caucasus.

Gamsakhurdia believed that a Georgian-Chechen allegiance was pivotal to the success of the common Caucasus home. ${ }^{643}$ This made Russia suspicious of his motives. But all this was only an improvised attempt to develop a foreign policy rather than an already established and well-thought-through strategy.

Later, Gamsakhurdia was blamed by the Georgian political elite for provoking Russia. It is clear that his policy toward Russia outraged the old imperial center without building links with the western major powers to balance Russia. Thus conflict in South Ossetia had already led to intervention by Soviet troops in the winter of 1990-1991. ${ }^{644} \mathrm{~A}$

\footnotetext{
${ }^{642}$ Rondeli, 2001, p. 207. The concept of a buffer implies the presence of strong and often hostile neighbors. Wight defines a buffer zone as 'a region occupied by one or more weaker powers between two or more stronger powers; it is sometimes described as a power vacuum.' He also notes that 'a buffer state is a weak power between two or more stronger ones, maintained or even created with the purpose of reducing conflict between them.' The Georgian nationalist leadership though that given the geopolitical position of Georgia and the increasing interdependence and economic integration of the world as a whole, the buffer zone alternative could be an ideal strategic choice, a third alternative for Georgia. See, M. Wight, "The Pattern of Power," in Power Politics, Hedley Bull and C. Holbran, eds., (London: Leicester University Press, 1995), p. 160.

${ }^{643}$ Stephen Jones, "The Role of Cultural Paradigms in Georgian Foreign Policy,” Journal of Communist Studies and Transition Politics, vol. 19, no. 3, pp. 83-110.

${ }^{644}$ Jonathan Aves, Georgia: From Chaos to Stability?, (London: The Royal Institute of International Affairs, 1996), p. 34.
} 
Yeltsin-Gamsakhurdia meeting in the spring of 1991 showed some signs of a potential alliance, but Gamsakhurdia's suspicion of Russia prevented him from establishing cooperation with Yeltsin. Gamsakhurdia's close relations with Jahar Dudayev, the Chechen independent movement leader, and his readiness to lend aid to the Chechen independent movement created animosity between his leadership and Yeltsin. ${ }^{645}$ Thus, he brought division to the Georgian multi-ethnic society that intensified ethnic conflict and international isolation. This presented an opportunity for internal and external rivalries to oust him.

Gamsakhurdia's era ended quickly. He was not in power long enough to develop a clear cut foreign policy. But even in his short reign he alienated Russia and the major western powers rejected his authoritarian leadership. They isolated Georgia with its domestic and regional problems. Failure to unite Georgia, boosting ethnic tensions among different minority groups and failing to establish regular security forces in Georgia were the major reasons for the overthrow of Gamsakhurdia. However, his role wasn't finished after he lost the presidential position.

The intervention of Russian forces in Abkhazia in 1993 provided an opportunity for Gamsakhurdia to return in western Georgia. Claming that he was trying to defend Sukhumi from the Abkhazian offense, Gamsakhurdia organized Circassian mercenaries including Chechens to challenge Shevardnadze's forces and try to seize control of the country. Sukhumi fell to the Abkhazians in September, and Gamsakhurdia's paramilitary forces set out from western Georgia toward Tbilisi. Shevardnadze, with help of Russian

\footnotetext{
${ }^{645}$ Jonathan Aves, "National Security and Military Issues in the Caucasus: The Causes of Georgia, Azerbaijan, and Armenia," pp. 209-233 in State Building and Military Power in Russia and the New States of Eurasia, ed. By Bruce Parrott (Armonk; M.E. Sharpe, 1995), p. 226.
} 
forces, pushed back Gamskhurdia's forces. Gamsakhurdia killed himself in mysterious conditions in Samegreli, northwestern Georgia on 31 December $1993 .{ }^{646}$

\section{Eduard Shevardnadze (1992-2003)}

Shevardnadze became the Secretary of the Georgian Communist Party in 1972 after an early career in the Interior Ministry. He demonstrated his admiration of Russia with his speech "for Georgians, the sun rises not in the east, but in the north- in Russia. ${ }^{\text {"647 }}$ He stayed at the top of the Georgian Communist Party until Gorbachev appointed him Soviet Foreign Minister in 1985. He was known as a tetra melia (white fox) by the Georgian political elites. ${ }^{648} \mathrm{He}$ resigned his position in 1990 because he predicted that the conservative communist party members want to establish a dictatorial regime in the country. He was reappointed as the Foreign Minister of Soviet Union afterwards the unsuccessful coup in August 1991 but shortly after the Soviet Union collapsed.

In asking Shevardnadze to return to Tbilisi, Kitovani and Ioseliani acknowledged that only Shevardnadze could end the chaos in Georgia and attract international attention and assistance. Georgians said at that time, "the Armenians have the diaspora; the Azerbaijanis have oil; and we have Shevardnadze!" ${ }^{649}$ Therefore, the return of Shevardnadze in 1992 marked the beginning of a new era for both the international status

\footnotetext{
${ }^{646}$ Wheatley, 2005, p. 84.

${ }^{647}$ Ekedahl, 1997, pp. 22-23.

${ }^{648}$ George Hewitt, “Abkhazia, Georgia and the Circassians (NW Caucasus)," Central Asian Survey, 1999, vol. 18 , no. 4, p. 493.

${ }^{649}$ Ronald Suny, "Southern Tears: Dangerous Opportunities in the Caucasus and Central Asia," in Russia, the Caucasus and Central Asia: The 21st Century Security Environment, Rajan Menon, et al., eds., (Armonk: M.E. Sharpe, 1999), p. 157.
} 
of Georgia and Georgian foreign policy. Shevardnadze took Georgia out from its isolation and placed it within the international system. On the foreign policy aspects Shevardnadze was familiar to both Russia and the Western major powers, especially the United States and Germany. ${ }^{650}$ While he was Foreign Minister of the Soviet Union, Shevardnadze worked closely with Western leaders to end the Cold War, and was therefore well-known and well-respected by the ruling elites of major powers. Germany became the first country to post an ambassador to Georgia. On 25-26 May 1992, the United States Secretary of State James Baker made a special visit to Tbilisi to support Shevardnadze's leadership. Both Germany and the United States pledged political and financial assistance, which was crucial to securing Shevardnadze's fragile position. Thus, the mere personality of Shevardnadze was important enough to ensure western attention to Georgia. ${ }^{651}$

Shevardnadze had powerful enemies in both Russia and Georgia. Military officers and former Communist Party members in Moscow saw him as a traitor. His opponents in Tbilisi disliked him for his lack of nationalist credentials, his campaign against nationalists, and his defense of non-Georgian minorities in the 1970s. ${ }^{652}$ When he returned to Georgia in March 1992 Shevardnadze found a fragile and weak country which was under both internal and external threats. Some Russian political and military leaders, such as Alexander Rutskoi, vice president of Russia, Ruslan Khasbulatov, speaker of the Duma, and Pavel Grachev, defense minister, had challenged him in 1992

\footnotetext{
650 “Advisor Discusses Possible Election Outcomes,” Interfax 26 October 1995, in FBIS-SOV-95-208, 27 October 1995, pp. 71-72

${ }^{651}$ Irakly Areshidze, Democracy and Autocracy in Eurasia: Georgia in Transition, (East Lansing: Michigan State University Press, 2007), pp. 26-27.

${ }^{652}$ Ekedahl and Goodman, 1997, p. 261.
} 
and 1993; major western powers who benefited from his policies in the 1980s, when he was foreign minister of Soviet Union demonstrated diplomatic support but ignored his calling for major western powers to balance against Russian influence and activities in Georgia.

Russia began to dominate its neighbors in the Caucasus, invading Chechnya, deploying military forces to Abkhazia and South Ossetia in Georgia, and putting pressure on Shevardnadze's government. Although Shevardnadze put forward foreign policy goals to develop strategic relations with the West, he turned to Russia because he believed the risk would be greater if he did not, given Georgia's threatened disintegration, the weakness of its government, and the disinterest of the western major powers in the Caucasus. He had become dependent on Russia for his political and personal safety. Therefore, Shevardnadze put a high priority on improving relations with Russia. The Russian foreign minister, Andrei Kozyrev, visited Tbilisi in April 1992, and negotiations were begun to draw up a wide-ranging bilateral treaty. ${ }^{653}$ The South Ossetian cease-fire was agreed in June 1992, mediated by the Russians. Certainly, Russia's role in helping to obtain and maintain a ceasefire in Ossetia paid dividends for Georgia.

In March 1993, however, Shevardnadze openly called the war in Abkhazia a Russian-Georgian conflict. Later, however, he pleaded for Russian assistance against Gamsakhurdia's forces that were closing in on Tbilisi. Shevardnadze visited Moscow in October 1993 to gain military support against Gamsakhurdia. Before he left Tbilisi for Moscow in September, he remarked: "A politician cannot afford to stubbornly persist in

${ }^{653}$ Lynch, 1998, p. 134. 
his view simply out of pride. Politicians must adapt to circumstance. ${ }^{\text {"654 }}$ In exchange for Moscow's military assistance, Shevardnadze was forced to accept increased Russian influence and presence in Georgia as well as Russian access to Black Sea ports-including Poti, the key to roads and rail lines to Tbilisi. Russian military forces established control over the rail lines and oil pipelines that linked Russia to Georgia, Azerbaijan, and Armenia. Russia kept four military bases in Georgia. ${ }^{655}$ The main task of these forces would be to secure Russian interests in the region against outside threats. He also accepted Georgia's CIS membership after the Russian defense minister insisted on this as a condition for Russian assistance to Shevardnadze's government. ${ }^{656}$ In addition, he publicly supported the Russian invasion of Chechnya. In return, Shevardnadze received additional Russian military assistance, particularly tanks and armored personnel carriers. Shevardnadze's move can be characterized as 'omnibalancing' because he was trying to appease the secondary threat, Russia, in order to allay the primary threat of internal disintegration and to ensure his own political survival. ${ }^{657}$

The defeat in Abkhazia actually played to Shevardnadze's advantage in as much as the population blamed the paramilitary leaders for the conflict. This enabled Shevardnadze to push the latter out of the power center and to strengthen his own power base. In order to achieve this, he made overtures to the former communist elite, the intelligentsia and certain quarters of the opposition. He appointed former KGB and ex-

\footnotetext{
${ }^{654}$ Ekedahl and Goodman, 1997, p. 269.

${ }^{655}$ Areshidze, 2007, p. 30.

${ }^{656}$ William Odom and Robert Dujarric, Commonwealth or Empire? Russia, Central Asia and the Transcaucasus, (Indianapolis: Hudson Institute, 1995), pp. 85-86.

${ }^{657}$ Rondeli, 2001, p. 202.
} 
Soviet military officers to "power ministers." For example, the Minister of National Security was Igor Giorgadze, former KGB officer and Minister of Defense was Vardiko Nadibaidze, a former Soviet military officer. He consolidated his power and stabilized political conditions in his country. ${ }^{658}$ Finally, in autumn 1993, Shevardnadze created his own political party, the Union of Georgian Citizens.

Meanwhile, Shevardnadze began to develop closer ties between Georgia and the United States. Shevardnadze visited the United States for the first time as the Georgian leader in March 1994 to obtain aid and encourage the United States to get involved in the region. The visit was the turning point for Georgian foreign policy. Just months before, he signed an agreement with Yeltsin to permit Russian military bases in Georgia for 25 years. However, the Georgian parliament refused to ratify until the Abkhazian and South Ossetian issues were solved. ${ }^{659}$ He met with Clinton, and two leaders held a news conference together at the White House, with the United States pledging over 70 million dollars in aid. More importantly, the visit provided an opportunity for Georgia to get involved in the pipeline project of the Caspian Sea, which in turn increased American interest in Georgia. ${ }^{660}$ Meanwhile, the Clinton administration was criticized for its Caucasus and Central Asia policy. The administration started to shift its policy on Caucasus and Central Asia. ${ }^{661}$

\footnotetext{
${ }^{658}$ Wheatley, 2005, p. 87.

${ }^{659}$ Areshidze, 2007, p. 35.

${ }^{660}$ Areshidze, 2007, p. 36.

${ }^{661}$ Ekedahl, 1997, pp. 275-277; and Zbigniew Brzezinski, “The Premature Partnership,” Foreign Affairs, March-April 1994, vol. 73, p. 70.
} 
By mid-1995, Georgia had taken some steps towards the establishment of a viable state. The state had a virtual monopoly over the use of force. Parliamentary and presidential elections were held. Shevardnadze and his party won the presidential election of November 1995. The Union of Georgian Citizens became the leading force in parliament. In 1995, parliament approved a new constitution that significantly changed the power structure of the Georgian government. The presidential office was granted almost unlimited authority and in this regard resembled that of Azerbaijan. ${ }^{662}$

Believing that Russia was behind the assassination attempt in 1995, the Georgian government ordered that the search for suspects begin with Russian military bases. ${ }^{663}$ The attempt led to a worsening of relations between Russia and Georgia. Shevardnadze fired most former Soviet officials but interestingly he left in place his defense minister, Nadibaidze, who had close ties to Russia. As a result, Georgia had sought to strengthen ties with the United States and the other western powers.

Meanwhile, international conditions began to change, as western oil companies signed with Azerbaijan the "contact of the century" deal and Georgia became a potential pipeline route for the Caspian oil. Western interests in the region consequently grew in the middle of the 1990s. Moreover, the Georgian government blamed a third assassination attempt against Shevardnadze in February 1998 on unidentified circles in Russia intent on disrupting his role in Caspian export plans. ${ }^{664}$ Several days before this attempt, Shevardnadze met with the president of the Azerbaijan National Oil Company

\footnotetext{
${ }^{662}$ Wheatley, 2005, p. 92.

${ }^{663}$ Georgy Dvali, "Signs of Chechen Connection in Attempt on Shevardnadze's Life Don't Keep Tbilisi From Seeing 'Hand of Moscow'" Kommersant, 11 February 1998, p. 3, in The Current Digest of the PostSoviet Press, 1998, vol. 50, no. 6, p. 18.

${ }^{664}$ Nodia, 2000, p. 197.
} 
(SOCAR) and the chairman of the AIOC to discuss renovation of the Baku-Batuni pipeline to carry "early oil" from the Caspian fields.

In conclusion, Shevardnadze was trying to make Georgia's foreign policy more realistic, balanced and pragmatic. During his tenure, Georgia's main foreign policy problem has been how to manage relations with Russia. Initially, Shevardnadze hoped that relations with Russia would improve and that this improvement would lead Russia to help resolve the Abkhazian and South Ossetian problems in Georgia's favor. He also wished to have a multi-vector foreign policy. While recognizing the need to maintain good relations with Russia to stay in power, he emphasized the need to seek out alternative relations particularly with the United States, neighboring Turkey, and Azerbaijan in order to provide a necessary balance. ${ }^{665}$ During the second half of the 1990s, both Shevardnadze and Zhvania believed that the only way to provide security to Georgia was to make Georgia members of the European political and security community, such as European Union and NATO. Shevardnadze also noticed that the Caspian oil project would attract international attention to the region. He invested his diplomatic skill to convince western major powers and oil corporations to pass the main Caspian oil pipeline through Georgia.

\section{5c. Georgia and Russia}

Georgia's relations with Russia cannot be described as simple and straightforward. They had a history of close relations shaped by Georgia as part of the Russian Empire and later as part of the Soviet Union. The Russian and Georgian people have shared their culture and history for almost two centuries. On the one hand, Georgia in the $19^{\text {th }}$ and $20^{\text {th }}$ centuries considered Russia as a door to Europe and a link to

\footnotetext{
${ }^{665}$ Dawish and Parrott, 1994, pp. 225-226.
} 
European culture, as well as a powerful neighbor sharing the same faith and ready to protect Georgia at critical moments. ${ }^{666}$ These common perceptions changed after Georgia declared its independence in 1991.

Because of the declaration of independence in April 1991 and rejection of any talk of joining the CIS, Gamsakhurdia antagonized and provoked the Russian government. Gamsakhurdia's nationalist policies aroused strong suspicion among Russian political elites as to his intention. Moreover, his close relations with Dudayev and support to the Chechen guerillas made Russian military and political elites consider him as an enemy and potential threat to Russian interests in the region. ${ }^{667}$

Shevardnadze, however, was aware of the Georgian dilemma. He viewed Russia as the hegemonic power in the region. He already realized how the Russians manipulated ethnic differences in Georgia, such as in the South Ossetian conflict. It was clear to him that Georgia needs Russia more than Russia needs Georgia. Therefore and in spite of Georgia's fear and suspicions about Russian threats, Shevardnadze considered Russia as the hegemon power in the region and important to Georgia in dealing with internal threats and chaos. Shevardnadze turned to Moscow because he believed the risk would be greater if he did not, given Georgia's threatened disintegration, the weakness of its government, and the international community's disinterest in the Caucasus.

Therefore, one of Shevardnadze's first actions was to establish good relations with the Yeltsin government. The first real result of Russian-Georgian relations was a ceasefire in South Ossetia. The Russian foreign and defense ministers visited Tbilisi and

\footnotetext{
${ }^{666}$ Rondeli, 2001, p. 203.

${ }^{667}$ Aves, 1995, p. 224.
} 
negotiated on a package of documents. ${ }^{668}$ Georgia agreed on the establishment of Russian military bases on Georgia's territory. In addition to three main bases in Vaziani, Akhalkalaki and Batumi, Russia acquired almost the entire coastal infrastructure from Poti to Gudauta. However, meanwhile, the war between Georgia and Abkhazia intensified. Shevardnadze understood that Russia could help to stop the war and help Georgia to gain control of Abkhazia. Therefore, he declared that he would sign the treaty only after Georgia's authority had been established throughout the entire territory of the republic, including Abkhazia and South Ossetia. ${ }^{669}$ In the middle of September 1993, the Abkhazian separatists with help of the local Russian commanders and Circussians launched a military offensive, and by the beginning of October, the Georgian military force and almost all the Georgian population in Abkhazia had been swept back to the Inguri River. ${ }^{670}$

This forced Shevardnadze to perform a significant turn in foreign policy. He called this foreign policy a "reserved policy." He sought to develop a close relationship with Moscow in order to end Russian support for Abkhaz separatism and to have Russian support against Gamsakhurdia's military forces. Therefore, under these circumstances, Shevardnadze visited Moscow in October 1993 to gain military support against Gamsakhurdia's military forces and asked for Russian assistance to solve the Abkhazian issue peacefully. In exchange for Russian assistance, Shevardnadze accepted Georgian membership in the CIS, which increased Russian hegemony in Georgia. In return, Russia

\footnotetext{
${ }^{668}$ Fuller, 1996, pp. 181-182.

${ }^{669}$ Editors' Note, "Result of Pavel Grachev's Visit to the Transcaucasus: Minister at the 'Point of Return'; A Tour of Stalin Sites," Kommersant, 25 March 1995, p.4. in The Current Digest of the Post-Soviet Press, 1995,vol. XLVII, no. 12, p. 22.

${ }^{670}$ Lynch, 1998, pp. 15-16.
} 
brokered first a ceasefire between the Abkhaz and the Georgians on December 1, 1993 and Yeltsin agreed to arm the Georgian military. The Georgian military forces defeated Gamsakhurdia's forces and established control all over Georgia except Abkhazia and South Ossetia. Basically, Shevardnadze had been forced to omnibalance against Gamsakhurdia's forces (internal threat) with help of the Russian (secondary threat) assistance. This effectively brought Georgia back into the Russian sphere of influence but Shevardnadze secured his leadership against Gamsakhurdia. ${ }^{671}$

On February 3, 1994, Georgia signed an all-embracing "Framework Treaty of Friendship and Good Neighborness" with Russia, along with a military agreement. According to the treaty, Russia obtained access to Georgian Black Sea ports, the key to roads and rail lines which link Russia to Georgia, Azerbaijan, and Armenia. The agreement introduced Russian peacekeepers into Georgia. Georgia accepted the joint patrol of the Georgian-Turkish border by Georgian and Russian military forces. In addition, Shevardnadze publicly supported Russia during the first Russo-Chechen war. With the agreement Georgia also received additional Russian military assistance, particularly tanks and armored personnel carriers. As a result, Russia exploited the chaotic situation and pressured Shevardnadze to accept Georgian membership in the CIS and the presence of Russia's military bases in Georgia. ${ }^{672}$

However, there was resistance to Russian influence in Georgia and the Georgian parliament refused to ratify the Russo-Georgian Friendship Treaty. Indeed, since

\footnotetext{
${ }^{671}$ Barylski, 1995, p. 49.

${ }^{672}$ Dawish and Parrott, 1994, pp. 225-226.
} 
Shevardnadze's visit to the United States in April 1994, he had tried to reduce Russia's influence in Georgia by improving ties with the West. ${ }^{673}$

Russian-Georgian relations had gradually declined since the assassination attempt on Shevardnadze in August 1995. As he was heading to a ceremonial signing of the new Constitution on August 29, Shevardnadze suffered an assassination attempt. It was never proven who exactly was responsible for the attack. Shevardnadze, and the Georgian government, blamed an alliance between Igor Giorgadze, the former minister for national security, and Mkhedrioni leaders. Former National Security Minister Giorgadze fled from Georgia after the assassination attempt from the Russian military base at Vaziani (near Tbilisi) to Moscow. Mkhedrioni's leaders, including Ioseliani, were arrested. ${ }^{674}$ The Russian government had denied the possibility that the organizers of the attack had any kind of "Russian connection." ${ }^{675}$ However, Giorgadze, along with Defense Minister Nadibaidze, was given a cabinet post as part of a deal between Shevardnadze and Yeltsin. Therefore, the Georgian government believed that the Russian military helped Giorgadze in the assassination attempt.

Russian-Georgian relations worsened in the second half of the 1990s. Tensions between Georgia and Russia started again as a result of Abkhazian attacks in 1998. The Georgian forces were defeated by the Abkhazian forces, despite the presence in the region of Russian peacekeeping forces. Shevardnadze threatened to take his country out

\footnotetext{
${ }^{673}$ Hunter, 2000, p. 46.

674،"Russians Reportedly Helped Giorgadze To Flee,” Sakinform, 31 October 1995, pp. 70-71, FBIS-SOV-95-211, 1 November 1995.
}

${ }^{675}$ Tesemnikova and Nodar Broladze, "The Omnipotence of 'Oil Terrorism' Is Greatly Exaggerated," Nezavisimaya Gazeta, Feb. 12, 1998, p.1, p. 5, in The Current Digest of the Post-Soviet Press, 1998, vol. 50, no. 6, p. 18. 
of the CIS and asked Russian peacekeepers to leave Georgia. For Georgia it became a priority to rid itself of Russian peacekeeping forces as well as the bases and border forces. In other words, Shevardnadze opposed a solely Russian peacekeeping force because it implied international recognition of a special Russian role in the 'near abroad.'

The failure of the security relationship with Russia to deliver Abkhazia and South Ossetia back to Georgia has resulted in Georgian consideration to Russia as the main external threat, and has promoted closer Georgian security ties with the West. Georgia openly expressed desire to join NATO and to become a member of the EU. In addition to that, Georgia blamed a Russian inner circle for another assassination attempt against Shevardnadze in February $1998 .{ }^{676}$ Shevardnadze survived. Initially, responsibility for the attempt was placed on pro-Russian political elites in Georgia and their Russian supporters because of the similarities to the previous failed attempt on Shevardnadze's life $1995 .{ }^{677}$ Therefore, Shevardnadze redefined Georgia's foreign policy orientation by consolidating military-security ties with major western states, bilaterally and multilaterally through the PfP framework. This orientation was boosted by the appointment of the pro-Western David Tevsadze as Georgia's defense minister in April $1998 .^{678}$

Furthermore, Russian-Georgian relations totally broke down with the second Chechen war. Georgia was unable to establish control over the situation in the Pankissi

\footnotetext{
${ }^{676}$ Stephen Kinzer, “A Defiant Satellite, Georgia Finds Paternalistic Russia’s Orbit Inescapable,” New York Times, 3 May 1998; and Elizabeth Fuller, "Is Georgia Inherently Unstable," RFE/RL Newsline, 29 October 1998, vol. 2, no. 209.

${ }^{677}$ Nodia, 2000, p. 189.

${ }^{678}$ Roy Allison, "The Military and Political Security Landscape in Russia and the South," in Russia, the Caucasus and Central Asia: The 21st Century Security Environment, Rajan Menon, et al., eds., (Armonk: M.E. Sharpe, 1999), pp.31-32.
} 
gorge, its border with Russia over the Chechen sector. Russia introduced a visa regime for Georgian citizens but excluded people who lived in Abkhazia and South Ossetia from it. Russia tried to preserve its military bases in the minority-populated areas of Georgia such as Abkhazia and Meskhet-Javakhetia region. All these contributed to a rise of hostility between two countries. ${ }^{679}$ Russia complained that Chechens use Pankissi as a base for operations in Chechnya. ${ }^{680}$ These allegations were denied by the Georgian government. Russia put intense pressure on Georgia to agree to a Russian operation to rid the gorge of Chechen separatists, a proposal Georgia firmly rejected. Nonetheless, Russian planes bombed northern regions of Georgia several times.

In 1999, Georgia withdrew from the Tashkent Treaty, mainly because it had failed to restore Georgia's territorial integrity. ${ }^{681}$ Moreover, Georgia and Russia signed an agreement in November 1999 at the OSCE summit in Istanbul, according to which Russia agreed to vacate three military bases in Georgia by July 2001. Both of these bases were air bases, one near the city of Vaziani and one in Gudauta in Abkhazia. Talk on handing over the third Russian base, located in Batumi in Adjara was scheduled to begin in $2000 .^{682}$

In conclusion, both Gamsakhurdia and Shevardnadze had accused Russia of perpetuating ethno-nationalistic conflicts in Georgia, implying that Russia manipulated

\footnotetext{
${ }^{679}$ Anna Matveeva, “Georgia: Peace Remains Elusive in Ethnic Patchwork,” pp. in Searching for Peace in Europe and Eurasia: An Overview of Conflict Prevention and Peacebuilding Activities, Paul Van Tongeren,et al., eds., (Boulder: Lynne Rienner Publisher, 2002), p. 436.

${ }^{680}$ Zeyno Baran, “The Caucasus: Ten Years after Independence,” The Washington Quarterly, Winter 2002 , vol. 25 , no. 1 , p. 224.

${ }^{681}$ Rondeli, 2001, p. 204.

${ }^{682}$ Oksana Antonenko, "Russia’s Policy in the Caspian Sea Region: Reconciling Economic and Security Agendas," in The Caspian: Politics, Energy, and Security, Shirin Akiner, ed., (London: Routledge Curzon, 2004), p. 259.
} 
regional conflicts so as to justify maintaining a military presence in Georgia and influencing its foreign policies. ${ }^{683}$ In particular, there was strong evidence that Russian troops stationed in Abkhazia were the main source of armaments for the Abkhazian forces, and were also involved in fighting on their behalf. ${ }^{684}$ Therefore, Russia's stance toward the Abkhaz-Georgian conflict resolution provoked anti-Russian attitudes in Georgia's domestic and foreign policies. ${ }^{685}$

Georgia has clearly tried to reduce its dependence on Russia and slowly move out of the Russian sphere of influence. For many Russian political elites this is a clear sign of an ungrateful and treacherous attitude towards Russia. This kind of emotional judgment is easy to understand, as Georgia has been trying to conduct an independent foreign policy and define its national security priorities. It attempts to reduce its dependence on Russia and establish close relations with other neighboring and western countries are taken by the Russian authorities not only as anti-Russian moves but also as strategically incorrect ones for Georgia, given its proximity to Russian power. ${ }^{686}$

\footnotetext{
${ }^{683}$ Ghia Nodia, "A New Cycle of Insecurity in Georgia: New Troubles and Old Problems," in Crossroads and Conflict: Security and Foreign Policy in the Caucasus and Central Asia, Gary K. Bertsch, et al., eds., (New York: Routledge, 2000), p. 188.

${ }^{684}$ Emil A. Pain, "Contagious Ethnic Conflicts and Border Disputes Along Russia's Southern Flank,” in Russia, the Caucasus and Central Asia: The 21st Century Security Environment, Rajan Menon, et al., eds., (Armonk: M.E. Sharpe, 1999). p. 185.

${ }^{685}$ Pain, 1999, p. 195.

${ }^{686}$ Rondeli, 2001, p. 205.
} 


\section{5d. Other Players}

\section{The United States}

U. S. political elites have known Shevardnadze, because of his role in ending the Cold War as the Soviet Union foreign minister, better than any other Caucasian leader. ${ }^{677}$ In asking Shevardnadze to return to Tbilisi, the Georgian political elites believed that only Shevardnadze could attract Western attention and assistance; however, they quickly realized that the United States had little interest in the region. Moscow began to dominate its neighbors in the Caucasus, invading Chechnya, and politically and militarily assisting separatists in Abkhazia and South Ossetia. The United States did not respond to the Russian action and Shevardnadze's requests for assistance because the United States government considered Georgia as a place far outside the traditional sphere of United States influence. Thus, the Georgians' expectations, that Shevardnadze could attain a breakthrough in relations with the West, turned out to be fruitless. Even though the United States Secretary of State James Baker visited Tbilisi after Shevardnadze came to power in spring 1992 and Shevardnadze had opened diplomatic relations for Georgia with the major western powers, the United States and the other major western powers had not been willing fully to support Georgia and establish a strategic relationship with it. ${ }^{68}$ On the contrary, they became receptive to Russian claims in the former Soviet republics.

In October 1993, the U.N. Security Council passed a resolution approving the sole Russian 'peacekeeping' role in Georgia. ${ }^{689}$ The Clinton administration's comparison of

\footnotetext{
${ }^{687}$ Nikolai Kovalsky, “Russia and the Black Sea Region,” International Affairs (Moscow), 1994, no. 10, p.115.

${ }^{688}$ Fuller, 1996, pp. 180-181.

${ }^{689}$ From May to October 1993, three different resolutions were accepted by the United Nations Security Council. They are 849 in July, 858 in August, and 876 in October. See, Baev, 1997, p. 46.
} 
Russia's intervention in Georgia to United States' action in Grenada and Panama gave the Russians complete freedom to intervene in the region. ${ }^{690}$ As a result, the Russian government, assigning the Caucasus to its sphere of influence, compared its intervention in Georgia to the United States' role in Haiti. ${ }^{691}$ In addition to that, the United States rejected Shevardnadze's request to involve a United Nations peacekeeping mission as well as to expand the United Nations observer mission into a full-scale United Nations peacekeeping force in Abkhazia. ${ }^{62}$ Therefore, even though Shevardnadze was initially opposed to a solely Russian peacekeeping force in Georgia, he had to comply with a dominant Russian role as a last choice because he was facing other internal threats, lacked military force of his own, and the United States as the global power refused to take the lead in arranging United Nations peacekeeping. Shevardnadze had been disappointed by the United States and forced to depend on Russia. ${ }^{63}$

After Shevardnadze's visit to the United States in April 1994, the relations between the United States and Georgia increased. Georgia joined NATO's PfP program the same year. The United States provided opportunities for Georgian military officers to study in the United States and trained and equipped Georgian military forces in antiterrorist operations. But the real breakthrough happened after the "Contract of the Century" oil deal signed in 1994 by the Azerbaijani government with a consortium led by

\footnotetext{
${ }^{690}$ R. Hrair Dekmejian and Hovann H. Simonian, Trouble Waters: The Geopolitics of the Caspian Region, (London: I. B. Tauris, 2001, p. 132.

${ }^{691}$ Zbigniew Brzezinski, “The Premature Partnership,” Foreign Affairs, March/April 1994, vol. 73, no. 2, p. 70 and Ekedahl and Goodman, 1997, p. 277. See also, Farhan Haq, "Georgia-Haiti: Did the United Nations Host a Great Power Trade?" IPS- Inter Press Service, 1 July 1994; and Georgia Gedda, "Russia Backs U.S. Haiti Policy But for a Price,” The Associated Press, 2 August 1994.

${ }^{692}$ Fuller, 1996, p. 182.

${ }^{693}$ Fuller, 1996, p. 182.
} 
the major American oil companies and the victory of communist and nationalist in Russian December 1993 parliamentary elections.

The United States now abandoned its 'Russia-first policy' and accepted a new 'Caspian policy' and saw Georgia as a strategic country in the region and a transit country in which an oil pipeline could be built from the Caspian Sea through Georgia and Turkey to provide an alternative to already existed route through Russia. ${ }^{694}$ In addition, Georgia was now considered of strategic importance as a buffer between Russia and NATO by the American political elite. ${ }^{695}$

Shevardnadze realized that Western interest in the Caucasus was triggered by its substantial natural resources. The South Caucasus is rich in oil and gas resources, which has brought serious Western economic interests into the region and is expected to contribute to the economic development of the region as a whole and Georgia in particular. ${ }^{696}$ Therefore, Shevardnadze regarded the Caspian pipeline project as politically an opportunity to decrease Russian influence in Georgia and economically as vital in collecting transit fees from the pipeline. Moreover, Shevardnadze expected that closer links with NATO member countries, like the United States and Turkey, could lead the alliance to enforce a peace deal in Abkhazia as preferred by Georgia.

Georgia's promise as a partner in the transport of Caspian oil was recognized in October 1995, when Azerbaijan and a consortium of mostly Western oil companies selected a pipeline from Baku to the Georgian Black Sea port Supsa to serve as one of

\footnotetext{
${ }^{694}$ Damien Helly and Giorgi Gogia, "Georgian Security and the Role of the West," in Statehood and Security: Georgia after the Rose Revolution, (Cambridge: The MIT Press, 2005), p. 276.

${ }^{695}$ Helly and Gogia, 2005, p. 283.

${ }^{696}$ Rondeli, 2001, p. 209.
} 
two pipelines carrying early Azerbaijani oil to market. ${ }^{697}$ Moreover, as the Baku-TbilisiCeyhan oil pipeline project became the only main export pipeline project in the region-because the pipeline bypasses Russia, which had the Chechen war at that time, and Armenia, with its conflict with Azerbaijan on the Karabagh issue-- Georgia became the only possible transit routes for Baku-Ceyhan pipeline. ${ }^{698}$ Russia considered the pipeline project as an anti-Russian project because Russia feared that the project could distance the South Caucasus states from Russian influence.

Georgia's relations with the West in general, and the United States in particular, grew much stronger in the second half of the 1990s. Following a visit by Shevardnadze to Washington in July 1997, Georgian-United States cooperation, particularly in the realm of security issues, accelerated greatly. Since Nadibaidze was replaced as Georgian defense minister in 1998 by West Point graduate David Tevzadze, bilateral defense cooperation with the United States increased. ${ }^{699}$ Georgia signed a milestone security cooperation agreement with the United States in March 1998. The document not only envisaged U. S. assistance to Georgia in several areas, including control of national airspace and territorial waters and modernization of radio communications for land forces, but it also provided for joint military exercises in 1998, both bilaterally and in the framework of the PfP. ${ }^{700}$ Under a separate agreement, the Pentagon pledged to hand over

\footnotetext{
${ }^{697}$ Michael P. Croissant, "Georgia: Bridge or Barrier for Caspian Oil," in Oil and Geopolitics in the Caspian Sea Region, Michael P. Croissant and Bulent Aras, eds., (Westport: Praeger, 1999), p. 278.

698 John Roberts, "Pipeline Politics," in The Caspian: Politics, Energy, and Security, Shirin Akiner, ed., (London: Routledge Curzon, 2004), pp. 82-83.

${ }^{699}$ Scott A. Jones, "Turkish Strategic Interests in the Transacaucasus," in Crossroads and Conflict: Security and Foreign Policy in the Caucasus and Central Asia, Gary K. Bertsch, et al., eds., (New York: Routledge, 2000), p. 58.

${ }^{700}$ Croissant, 1999, p. 282.
} 
14 helicopters and two warships to the Georgian military, and to provide training to the embryonic Georgian navy. ${ }^{701}$

Moreover, the closing months of 1998 were marked by the first major port call by a United States naval vessel to Georgia and the signing of a defense cooperation document setting out more than thirty areas of joint activity and U.S. assistance to Georgia for $1999 .^{702}$ According to some scholars, "the Georgian-United States program appears to be second only to the Ukraine-NATO program in terms of bold planning by the newly independent countries and the Western military."703 In October 1998, Georgia joined the United States, Turkey, Azerbaijan, Kazakhstan, and Uzbekistan in the signing of the so-called "Ankara Declaration" which affirmed their support for construction of a major Caspian pipeline from Baku to the Turkish Mediterranean port of Ceyhan via Georgian territory. ${ }^{704}$

Therefore, in the late 1990s Georgian foreign policy was western oriented, and the Georgian government interested in joining NATO and EU. In addition to that, Georgia was trying to build strong relations with the United States and other major western powers, so as the better to allow the Georgian leadership to take advantage of geopolitical rivalries between Russia and the United States.

\footnotetext{
${ }^{701}$ Vladimir Socor, Elizabeth Teague, and Stephen Foye, "More Facts on U.S.-Georgian Military Cooperation Revealed,” Jamestown Foundation Monitor, 1 April 1998, 4, no. 63.

702 Peter Grigorian, "Shevardnadze Welcomes Assistance from U.S. Navy,” RFE/RL Newsline, 11 September 1998, 2, no. 176.

${ }^{703}$ Vladimir Socor, Elizabeth Teague, and Stephen Foye, “Georgia-U.S. Military Cooperation Program Signed," Jamestown Foundation Monitor, 11 November 1998, 4, no. 209.

${ }^{704}$ Elizabeth Fuller, "Five Presidents Sign 'Ankara Declaration”” RFE/RL Newsline, 30 October 1998, 2 , no. 210.
} 


\section{5e. Conclusion}

There were two different orientations of Georgia's foreign policy during the 1990s: 1991-1992 and 1994-1999 saw balancing against Russia, and 1992-1994 omnibalacing against internal threats. From 1991 to 1992, as the consequence of Gamsakhurdia's nationalist and anti-Russian foreign policy, Georgia alienated Russia. Gamsakhurdia's policies also alienated ethnic minorities, such as South Ossetians and Abkhazians and violent confrontations threatened the sovereignty of Georgia. These conflicts provided an opportunity for Russia to become involved in the domestic politics of Georgia. Because of Russian involvement in the Abkhazian and South Ossetian conflicts, Georgia found itself facing a potential conflict with Russia. This complicated both Georgian domestic and foreign relations.

Therefore, Gamsakhurdia distanced Georgia as far as possible from Russia and balanced the Russian influence in the region but he had problems in attracting western powers' involvement. Gamsakhurdia sought international recognition and legitimacy for Georgia and tried to establish links with the world beyond Russia. The numerous attempts to establish relations with the western powers during Gamsakhurdia's tenure all failed. The major western powers rejected his leadership and isolated Georgia with its domestic and regional problems. Therefore, Gamsakhurdia and his government became isolated from the international community and alienated Russia.

In the second period, when Shevardnadze returned to Georgia as a result of severe domestic conflicts and pressures, Georgia's foreign policy was reactive to internal threats. In this time period, the Georgian government faced fierce internal problems in the early 1990s, such as the wars of Abkhazia, and fighting against Zviadist paramilitary 
groups. This forced Shevardnadze to perform a significant turn in foreign policy. To deal with these challenges, he sought and received assistance from Russia, but the price was high. Therefore, Shevardnadze's foreign policy oriented towards Russia to omnibalance domestic rivalries and establish control over the state. Because Shevardnadze was aware of the Georgian dilemma, Georgia needed Russia more than Russia needed Georgia. Even though Georgia feared Russian threats, Shevardnadze considered Russia as important for Georgia to deal with internal threats and chaos. He already realized how the Russians manipulated ethnic minorities in Georgia. He made difficult decisions, like joining the CIS when most of the Georgian political elites as well the Georgian public considered Russia as the main threat. He accepted a Russian-brokered ceasefire for the South Ossetian and Abkhazian conflicts; membership of Georgia in the CIS; and the establishment of four Russian military bases on Georgian territory. In return, Russia provided military assistance to the Georgian military forces for defeating Gamsakhurdia's forces and establishing control all over Georgia except Abkhazia and South Ossetia. Basically, Shevardnadze had been forced to omnibalance against Gamsakhurdia's forces (internal threat) with help of the Russia (secondary threat) assistance. This effectively brought Georgia back into the Russian sphere of influence.

From 1994 to 1999, Shevardnadze managed to achieve full political control and had external alternatives to balance the Russian influence. This internal cohesion and stability positively affected the foreign policy orientation of the Georgian state. Since late 1994, Georgia managed to develop an active foreign policy. Despite the unsettled conflicts in Abkhazia and South Ossetia and the issue of the Russian military bases, Georgia's foreign policy became more Western-oriented. Moreover, the Russian 
influence on Georgia declined in the winter of 1994-95, when the first Chechen war started. Furthermore, in the summer of 1995, Shevardnadze's began successful efforts to gain international support for the rebuilding of a pipeline from Azerbaijan to Georgia's Black Sea coast. So both the Chechen war and oil pipeline issues provided Shevardnadze for maneuver space when dealing with Russia. Shevardnadze concentrated on attracting western interest to the region and making them balance Russian influence there.

Therefore, Georgia's foreign policy was largely determined by two main circumstances during the second half of the 1990s. One was Georgia's desire to decrease its dependence on Russia. The second one was increased political and military cooperation with the United States and NATO. In 1994 Georgia joined the NATO PfP programme and Shevardnadze visited the United States. The Georgian government also saw participation the Caspian Sea energy projects and transport corridors as a decisive objective for the Georgian foreign policy. ${ }^{705}$ Shevardnadze supported renovation of the Baku-Batumi pipeline to carry "early oil" from the Caspian fields, because the pipeline issue was not just a question of huge amounts of financial sources for Georgia but also an issue of Georgian relations with Russia. The pipeline could provide an opportunity for Georgia to decrease its dependence on Russia and develope close relations with major western powers. He also sought to benefit from United States-Russian competition on the Caspian oil reserves and worked to pass the main pipeline through Georgia so Georgia could benefit both economically and politically from the competition.

Finally, Georgia's relations with Russia cannot be described as simple and straightforward. Both Gamsakhurdia and Shevardnadze had accused Russia of

${ }^{705}$ Haindrava, 2003, pp. 22-23. 
perpetuating the ethno-nationalistic conflicts in Georgia, implying that Russia manipulated regional conflicts so as to justify maintaining a military presence in Georgia and influencing its foreign policies. Georgia has clearly tried to reduce its dependence on Russia and slowly move out of the Russian sphere of influence. Georgia has been trying to conduct an independent foreign policy and define its national security priorities. It attempts to reduce its dependence on Russia and establish close relations with other neighboring and western countries are taken by the Russian authorities as anti-Russian moves.

\section{The Caucasus and Russia}

Despite the disintegration of the Soviet Union, Russia remains the key regional power in the Caucasus. The relationship between the Caucasus states and Russia is based on a very complex set of perceptions and interests. The Caucasus states have only in recent times been capable of undertaking independent foreign policy initiatives, as a weakened Russia turned its face to other pressing issues. This is a clear indication that Russia is the most important actor as well as a factor for the foreign policy processes of the Caucasus states. Therefore, the Caucasus states have had a delicate sense of the risks and opportunities offered by this relationship. Since independence, the leaders of the Caucasus states have been deeply concerned with Russian interference in their internal affairs. $^{706}$

\footnotetext{
${ }^{706}$ John P. Willerton and Geoffrey Cockerham, "Russia, the CIS and Eurasian Interconnections," in Limiting Institutions? The Challenge of Eurasian Security Governance, James Sperling, et al., eds., (Manchester: Manchester University Press, 2003), p. 185; and Ruth Deyermond, Security and Sovereignty in the Former Soviet Union, (Boulder: Lynne Rienner, 2008), pp. 50-51. See also, Adeed Dawisha and Karen Dawish, eds., The Making of Foreign Policy in Russia and the New States of Eurasia, (Armonk: M. E. Sharpe, 1995) and Uri Ra'anan and Kate Martin, eds., Russia: A Return to Imperialism, (New York: St. Martin's Press, 1995).
} 
The chaotic circumstances of the 1990s led to the fears that external forces, especially the Russian Federation and/or other major powers interested in the region, might provoke domestic instability. On the one hand, Russia became the center of this fear, because Russia had dominated and ruled the region for more than two hundred years. On the other hand, the Caucasus leaders worry about who would guarantee their security if Russia withdrew entirely from the region. ${ }^{707}$

The Russian influence on the Caucasus region may be explained by three factors: the historical legacy of Russia in the region, Russian domestic politics, and Russia's strategic position in the region.

One of the legacies of Tsarist and Soviet empires is the pattern of patronage and clan ties, including those running from Russia to the former Soviet republics as well more local networks within former Soviet Union republics. The collapse of the Soviet Union did not eliminate the political significance of these links. Patronage and clan arrangements remained the most organized and institutionalized structures in Armenia, Azerbaijan and Georgia. However, the interruption of their common flow of resources from the center (Moscow) to the periphery (the Caucasus states) forced them to change network relations and to adopt new methods for mobilizing support for their clans. Moreover, this new relationship drove political elites of the Caucasus states into zerosum-game competition for control over political and economic resources in their countries. $^{708}$

\footnotetext{
${ }^{707}$ Karen Dawisha and Bruce Parrott, Russia and the New States of Eurasia: The Politics of Upheaval, (Cambridge: Cambridge University Press, 1994), p. 228.

${ }^{708}$ Jack Synder, "Introduction: Reconstructing Politics Amidst the Wreckage of Empire," in Post-Soviet Political Order: Conflict and State Building, Barnett R. Rubin and Jack Synder, eds., (London: Routledge, 1998), p. 6; and Kathleen Collins, Clan Politics and Regime Transition in Central Asia, (Cambridge; Cambridge University Press, 2006), pp. 62-67.
} 
Furthermore, the ruling elites in the Caucasus states established alliances within and outside the country and provided special benefits only for titular elites to increase their control in the new states. A new distribution of political positions by the ruling elites produced a complicated condition for the minority ethno-national groups. The minority ethno-national groups refused to orient their loyalty toward the newly established states. They preferred either being part of the Russian Federation or establishing their own independent states or annexing their region to de facto independent states established by their ethnic kin, such Abkhazians, South Ossetians, and Karabagh Armenians. Therefore, the allegiance of these groups to Russia and neighboring countries created a conflict between Russia and the Caucasus states as well as among the Caucasus states themselves. This conflict turned out to be the main threat for the Caucasus states.

A strong state making foreign policy is more dependent on state institutions than would be a weak state. The reason is that the state institutions involved in the foreign policy process in a strong state are plentiful and influential and competition among different state institutions in the state is rigorous. On the other hand, the number of state institutions in a weak state is low and their effects on the foreign policy process are limited. Besides, the lack of powerful state institutions in weak states opens the way to individual leadership becoming dominant players. For these reasons, state institutions in a strong state, and individual leaderships in a weak state, are very important in determining foreign policy. This framework explains differences between a strong state's foreign policy from those of weak states. For instance, there was a lot of interdepartmental struggle among various Russian governmental agencies and institutions to shape Russian foreign policy actions in the Caucasus during the 1990s. The Russian Foreign Ministry 
denounced Azerbaijan's right to develop its oil fields in the Caspian Sea but at the same time the Russian Fuel and Power Engineering Ministry was pushing for oil to be transported through Russia. ${ }^{709}$

Three domestic movements influenced Russian policy towards the Caucasus region during the 1990s: Neo-imperial, Conservative, and Pragmatic. ${ }^{710}$ The first was the Neo-imperial or Eurasianism trend, which reflects the interests of great power movements, neocommunists and nationalist parties who combined extreme nationalism and a desire to reestablish the Soviet Union. According to these groups and elites, Russia considers itself to be the main heir of the former Soviet Union. They declared themselves to be anti-United States, anti-NATO and anti-Western. They interpreted Eurasianism in both geopolitical and geoeconomical terms. They also claimed that Russia has a unique characteristic and role in world politics. Russia's unique and special role implied forging a special way in politics and economics which included authoritarian government and a

709 Elmar Guseinov, "Battle Over the Caspian Shelf Attests to Lack of Coordination Between Russian Government Departments," Izvestia, 29 September 1994, p. 4, in The Current Digest of Post-Soviet Press, 26 October 1994, vol. XLVI, no. 39, pp. 26-27; and Neil Malcolm, "Foreign Policy Making," in Internal Factors in Russian Foreign Policy, Neil Malcolm, et al., eds., (Oxford: Oxford University Press, 1996), p. 143.

${ }^{710}$ Although, scholars and experts on Russian Foreign Policy agree on criteria, but disagree terms to characterize different views and groups in the Russian foreign policy elites. For example, Margot Light uses Fundamentalist Nationalists, Pragmatic Nationalists, and Liberal Westernists. See, Margot Light, "Foreign Policy Thinking," in Internal Factors in Russian Foreign Policy, Neil Malcolm, et al., eds., (Oxford: Oxford University Press, 1996), pp. 34-35. More information about categories, see also some books, Mohiaddin Meshabi, "Russia and the Geopolitics of the Muslim South," in Central Asia and the Caucasus after the Soviet Union: Domestic and International Dynamics, (Gainesville :University of Florida Press, 1994), pp.273-274; Karen Dawisha and Bruce Parrott, Russia and the New States of Eurasia, (Cambridge: Cambridge University Press, 1994), pp. 199-202; Bobo Lo, Russian Foreign Policy in the Post-Soviet Era: Reality, Illusion and Mythmaking,(New York: Palgrave Macmillian, 2002), pp.40-42; and Andrei P. Tsygankov, Russia's Foreign Policy: Change and Continuity in National Identity, (Lanham: Rowman \& Littlefield Publishers, Inc., 2006), pp. 2-9. See, also some articles, Vladimir Lukin, "Our Security Predicament," Foreign Policy, Fall 1992, pp. 57-75; Vera Tolz, "Russia: Westernizers Continue to Challenge National Patriots," RFE/RL Research Report, 11 December 1992; Alexei Arbatov, "Russia's Foreign Policy Alternatives," International Security, 1993, vol. XVIII, no. 2, pp. 5-43; Allen C. Lynch, "Realism of Russia's Foreign Policy," Europe-Asia Studies, 2001, vol. 51, no. 1, pp. 7-31; and Celeste A. Wallander, "Russian Transimperialism and Its Implications," The Washington Quarterly, Spring 2007, vol. 30, no. 2, pp. 107-122. 
corporatist economy. They considered Russia as the only hegemonic power in Eurasia and challenger of the United States' global status. They also believed that Russia has a natural right to influence and control in the space of the former Soviet Union. They sought to maintain the Caucasus region, its resources and conflicts within the Russian sphere of influence and to resist competitive influence from the United States, Turkey, and the West generally. ${ }^{711}$

The second, conservative, trend was close to the neo-imperialist trend. Conservatives (Pragmatic Nationalists or Statists) rejected a return to past economic and political practices. They argued that Russia must develop an independent foreign policy vis-à-vis the West, based on Russian national interests. They considered the CIS area as a zone of vital Russian interests and that Russia should be responsible for stability in that zone. The Russian role in the CIS should also be recognized by the international community. Conservativists prefer that Russia continue a military presence in the Caucasus, and that the Russian military share in patrolling the Caucasus states' borders in order to protect Russian hegemony over the Caucasus but they rejected the reestablishment of the USSR. They also wanted to control the export of Caspian hydrocarbon resources. $^{712}$

\footnotetext{
${ }^{711}$ Margot Light, "In Search of an Identity: Russian Foreign Policy and the End of Ideology," in Ideology and National Identity in Post-Communist Foreign Policies, Rick Fawn, ed., (London: Frank Cass, 2003), pp. 43-44. Some scholars call this group as "Fundamentalist Nationalists." See, Lo, 2002, p. 41.

${ }^{712}$ Light, 2003, p. 45 and Sergei Medvedev, "Power, Space, and Russian Foreign Policy," in Understandings of Russian Foreign Policy, Ted Hopf, ed., (University Park: The Pennsylvania State University Press, 1999), pp. 43-44. A good example of pragmatic nationalism is Yevgeny Primakov. See, Leon Aron, "The Foreign Policy Doctrine of Postcommunist Russia and Its Domestic Context," in The New Russian Foreign Policy, Michael Mandelbaum, ed., (New York: A Council on Foreign Relations Book, 1998), pp.29-30 and Tsygankov, 2006, pp.93-96.
} 
The third trend, the pragmatic one, favored Russia's integration with the Westernoriented international political and economic institutions. Pragmatists argued that Russia should concentrate on investing its resources in the creation of a modern economy which should be integrated to the global economy and political system. They gradually wanted to withdraw Russian military forces and to rely on the assistance of international organization such as the OSCE in solving conflicts in the Caucasus. They emphasized that Russian relations with the Caucasus be based on mutual respect and the acknowledgement of legitimate economic interests. They believed that relations with Caucasus based on common interests would lead not only to the preservation of Russian interests in the region, but even to the expansion of Russia's position regionally and internationally. ${ }^{713}$ This trend was represented by the Russian oil companies, the Russian Fuel and Power Engineering Ministry, and the Russian business community.

Three factors influenced Russia's strategic position in the region in the 1990s: the other major powers in the region, Russian interests in the region such as controlling energy sources, and responses to potential threats from the region to Russian security. First, Russia would not feel threatened by its Caucasus neighbors but it would be more likely to feel threatened by the presence of a global or major power on its borders. In other words, the presence of other major powers such as the United States or the appearance of an alliance among its neighbors like GUAM from which Russia is excluded are a potential threat for the Russian concentric system in the region. As a consequence, in the late 1990s, Russia accepted its own limits and the existence of the

\footnotetext{
${ }^{713}$ Some scholars call them "Pragmatic Liberal," or "Westernists". Tsygankov, 2006, pp. 58-61.
} 
United States in the region. However, Russia assumes that even when the United States appears in the region, Russia is still the major power in the Caucasus region. ${ }^{714}$

Second, Russia perceives the Caucasus region as a part of its 'Near Abroad'. Russia's interest lies in two main areas. Firstly, Russia wants to reestablish control over the borders of the CIS. During the 1990s Russia favored the CIS as a vehicle for security co-operation between the former Soviet republics, so the CIS serves as the foundation of a Russian-led regional collective security system. The 1992 Tashkent agreement on collective security, the agreement for the joint defense of CIS borders, and the creation of a common air defense system implied collective security arrangements among the CIS members. ${ }^{715}$ Yet Russia itself was often seen as the principal security threat to the Caucasus, as historical legacies and geopolitical circumstances suggest. Indeed, Russian enthusiasm for enlarging the CIS, which it did successfully by forcing Georgia and Azerbaijan to join the organization by using its leverage over the civil wars in both countries, confirms this view. Moreover, Russia asked the official approval of the United Nations for special peacekeeping rights in the Caucasus, indicating that this is precisely the role of Russia envisions for the CIS. ${ }^{716}$

Secondly, Russia has tried to gain control over Azerbaijan's oil resources. There has, however, been disagreement among different ministers in the civil and military bureaucracies on how to achieve their goals. Contradictory views were expressed by

\footnotetext{
${ }^{714}$ Lo, 2002, pp. 116-117.

${ }^{715}$ Pavel Baev, Russia's Policies in the Caucasus, (London: The Royal Institute of International Affairs, 1997), pp. 4-5.

${ }^{716}$ Emil I. Pain, "Contagious Ethnic Conflicts and Border Disputes along Russia's Southern Flank," in Russia, the Caucasus and Central Asia: The $21^{\text {st }}$ Century Security Environment, Rajan Menon, et al., eds., (Armonk: M.E. Sharpe, 1999), p. 192.
} 
different Russian state institutions' on the Azerbaijan International Operating Company (AIOC) and the 'Contract of the Century' signed in Baku in 1994. Andrei Kozyrev, foreign minister of Russia, on the one hand, declared that Moscow did not recognize Azerbaijan's right to exploit the Caspian shelf oil fields. On the other hand, energy lobbies in Russia, led by prime minister Victor Chernomyrdin, tried to obtain a share of Azerbaijani oil reserves. ${ }^{717}$ In addition, in late 1995, Georgia and Russia were designated as the two transit countries for early oil coming from the exploitation of crude petroleum under the Caspian Sea by the AIOC. Interestingly, Yuriy Shafranik, Russian minister of fuel and power engineering, described the decision of the international oil consortium to transport the "early Caspian oil" along two routes- Georgian and Russian- as a win for Russia. He added, "Russia is still a great power; we have a ready option for transportation, great influence, and wide-ranging contracts in this region so we do not need to worry."

Third, Russia has used its influence in the region, including within zones of conflict, to defend its interests. Russia has been involved in all of the regional conflicts, sometimes as a party to a given conflict and sometimes as a mediator and/or peacekeeper under the aegis of the CIS and OSCE. In addition to that, Russia had sufficient leverage to influence the situation in the region, especially taking into consideration the presence of the Russian military bases in Armenia and Georgia and the Russian peacekeeping forces in Abkhazia, South Ossetia and Karabagh. ${ }^{719}$ For example, in Karabagh, Russia

\footnotetext{
${ }^{717}$ Igor Khripunov and Mary M. Matthews, "Russia's Oil and Gas Interst Group and Its Foreign Policy Agenda," Problems of Post-Communism, May/June 1996, vol. 43, no. 3 , p. 45; and Cornell, 2001, p. 359.

${ }^{718}$ Igor Ivantsov, "Fuel Minister Hails Decision on Caspian Oil Routes," ITAR-TASS World Service, 16 October 1995, in FBIS-SOV-95-199, 16 October 1995, p. 28.

${ }^{719}$ Baev, 1997, pp. 18-19.
} 
troops monitored a ceasefire that Russia brokered between Armenian and Azerbaijani military forces in 1994 and Russian diplomats have taken part in the OSCE-organized "Minsk group' as mediators and a co-chair of the group. In Abkhazia, inter-ethnic conflict was stimulated by Russia in order to pressure Georgia into joining the CIS. In South Ossetia the Russian peacekeepers monitored the Georgian-South Ossetian border. These conflicts are called "frozen conflicts" "720, as Russia-brokered cease-fire agreements between Armenia-Azerbaijan, and Georgia-South Ossetia and Georgia-Abkhazia, merely froze these conflicts in the region. In conclusion, Russian relations with each of the Caucasus states depend on the Russian roles in the regional conflicts and Russian interests in the region.

A starting point for analyzing Russia's bilateral relations with Azerbaijan is the failure of the coup attempt against the last Soviet president, Mikhail Gorbachev, in Moscow in August 1991. This coup attempt brought to an end a series of Soviet military operations in Karabagh that had been conducted by Soviet troops and Azerbaijani paramilitaries with the aim of disarming Armenian militias in Karabagh. After the Soviet Union collapsed, the Armenian military reorganized its forces and started an offensive against Azerbaijani irregular forces. The Armenian forces captured Shusha and controlled the Lachin corridor between Karabagh and Armenia in 1992. Yeltsin realized that the Karabagh conflict threatened to inflame the entire Caucasus region, with the changes that regional powers, such as Turkey and Iran, could become involved in the conflict. The turning point in Russia's policy on the Karabagh issue came with the appointment of

\footnotetext{
${ }^{720}$ Olga Vassilieva, "Conflict Management in the Caucasus via Development of Regional Identity," in Potentials of Disorder, Jan Koehler and Christoph Zurcher, eds., (Manchester: Manchester University Press, 2003), pp. 186-187.
} 
Vladimir Kazimirov as a special envoy with responsibilities for the Karabagh conflict. ${ }^{721}$ Even though Russia had joined a mediating initiative on the Karabagh issue with the United States and Turkey (the "Tripartite Initiative") in May 1993, the emphasis of the Russian approach was that the Caucasus is the sphere of influence of Russia and so Russia prefers solving regional problems by unilateral means.

Kazimirov initiated an active shuttle diplomacy between Baku, Yerevan and Stepanekent, paying particular attention to building an understanding with Aliyev, who had returned to power in Azerbaijan in summer $1993 .{ }^{722}$ His efforts were not immediately successful since the Armenian forces conducted a series of offensives, capturing Agdam in July, Fizuli and Jebrail in October and Horadiz in October. Seeking to prove its objectivity, Russia supported three resolutions of the United Nations Security Council condemning these offensives and demanded Armenian withdrawal from all occupied territories. ${ }^{723}$ Aliyev expected more substantial support from Moscow, particularly when he ordered a counter-offensive in December 1993; some territory to the north of Karabagh was recaptured, but casualties were heavy. ${ }^{724}$

Both Grachev and Kazimirov's efforts successfully produced a cease-fire between Armenia and Azerbaijan in 1994 but there is still small-scale fighting continuing in border areas, even though the conflict remains overall "frozen". Neither the Armenian nor the Azerbaijani sides could agree to end the conflict peacefully. The Russian role in

\footnotetext{
${ }^{721}$ Vladimir Kazimirov, "Nagorno-Karabakh: Five Years after the Cease-fire," International Affairs (Moscow), 1999, vol. 45, no. 4, pp. 93-107.

${ }^{722}$ De Waal, 2003, pp. 237-238.

${ }^{723}$ United Nations Security Council accepted three resolutions in 1993 on the Karabagh problem; UN resolution numbers of 822,853 , and 874 .

${ }^{724}$ De Waal, 2003, pp. 236-237.
} 
the conflict also shifted. Russia as one of the co-chairs the Minsk Group of the OSCE, became an active member of international effort for resolving the conflict. The 1997 revelation on its supply of arms to Armenia between 1994 and 1996 damaged Russia's relations with Azerbaijan, as the latter expressed concern about Russia's secret military aid to Armenia. ${ }^{725}$

Azerbaijan, with Ukraine, Georgia and Moldavia, created a bloc within the CIS in 1996, called GUAM (Georgia, Ukraine, Azerbaijan and Moldova). This made the Russian government worried about the intention of members of GUAM to develop close relations with the United States. In addition, Russia had concerns about Chechnya, where fighting between Russian military and Chechen guerrillas raised doubt about the possibility of transporting Caspian oil through Chechnya to Russia, thus increasing the likelihood of a western pipeline route through Georgia to Turkey. Under these circumstances, Russia saw Armenia as its only remaining ally in the South Caucasus. Therefore, Armenia became a symbol of promoting Russian interests in the region. Moreover, most in the Russian political and military elites saw Armenia as a tool against oil-rich Azerbaijan. ${ }^{726}$ In other words, Russian leverage on Armenia allows Russia to exercise considerable influence in the South Caucasus. Some of Russian military and political elites considered that Armenia could threaten the route of the Baku-TbilisiCeyhan oil pipeline, which passes close by the Armenian-Azerbaijani border; the pipeline

\footnotetext{
${ }^{725}$ De Waal, pp. 1999-200.

${ }^{726}$ Paul Goble, "Russia: Analysis from Washington-Using Minsk in the Caucasus," RFE/RL, 8 April 1997, in Armenian News Network groong@ usc.edu, accessed by 8 April 1997.
} 
also passes through areas of Georgia largely populated by ethnic Armenians, an area where there is a tendency to separatist activism and where Russia had a military base. ${ }^{727}$

Russian policy on Georgia has been influenced by several factors. Most of the Russian political and military elites were disappointed with the Georgian nationalists' demands in the late 1980s and early 1990s, seeing them as a betrayal of the long RussianGeorgian friendship. Second, Russian political elites blamed Shevardnadze as one of the political leaders who destroyed the Soviet Union. Moreover, Russian political elites regard Georgia as strategically vital for Russian interests in the Caucasus so that Georgia should either have a government friendly towards Russia or be divided along ethnic lines.

The Russian leadership had a problem with controlling and coordinating Russian relations with the former Soviet republics, particularly the post-Soviet Caucasus states, because there were several state institutions, such as the Russian presidential administration, foreign ministry, army and the other power ministries, pursuing their own institutional policies and interests. Throughout 1993 and 1994 the shaping of Russian foreign policy in the Caucasus was dominated by fierce internal political competition between these various institutions. ${ }^{728}$

As many Russian politicians and military officials remained reluctant to admit the reality of their independence in the 1990s, the Caucasus states remained concerned to preserve their sovereignty and independence from Russia. Although direct Russian political control over the Caucasus has been formally removed, this has not been reflected in a comparable withdrawal of Russian economic and military leverage in the region.

\footnotetext{
${ }^{727}$ Azad Isazade, “Armeniagate: Russia Arms One Side in the Armenian-Azerbaijani Conflict,” War Report, May 1997, pp. 16-17, Armenian News Network groong@usc.edu, accessed 12 June 1997.

${ }^{728}$ Neil Malcolm, "Russian Foreign Policy Decision-making," Russian Foreign Policy since 1990, Peter Shearman, ed., (Boulder: Westview Press, 1995), p. 28.
} 
Moreover, in clear contradiction of their policies of bolstering their political independence from Russia, leaders of the Caucasus states have sometimes sought Russian support and mediation for the local and civil conflicts in their countries and the region. Therefore, leaders of the Caucasus states have handled a very delicate set of relationships with Russia with varying degrees of skill. In the final analysis none of the Caucasus states could do much against a determined attempt by Russia to re-impose its hegemony in the 1990s. ${ }^{729}$ However, while Russia is clearly more powerful than the Caucasus states, it too underwent a serious political and economic crisis throughout the 1990s that had a considerable influence on its political and military capacity to project its power in the region. Russian weakness can be seen in the 1990s in the Balkans. Lacking the capability to provide political and military assistance to its ethnic kin and historical ally, Serbia, the Russian position in the international system weakened. In addition, the expansion of NATO was the number one problem for Russian diplomacy in the second half of the 1990s. Russia feared in this context that it could lose the Caucasus as well.

\section{Conclusion}

The Caucasus States-Russian Relations

\begin{tabular}{|c|c|c|c|c|}
\hline & $1991-1994$ & $1994-1997$ & $1998-1999$ & \\
\hline Armenia & Bandwagon & Omnibalance & Bandwagon & \\
\hline & $1991-1992$ & $1992-1993$ & $1993-1994$ & $1994-1999$ \\
\hline Azerbaijan & Omnibalance & Balance & Omnibalance & Balance \\
\hline & $1991-1992$ & $1992-1994$ & $1995-1999$ & \\
\hline Georgia & Balance & Omnibalance & Balance & \\
\hline
\end{tabular}

${ }^{729}$ Aves, 1995, p. 224. 
The relationship between the Caucasus states and Russia is fundamentally one of profound asymmetry. Asymmetric relations between Russia and the Caucasus states were analyzed in terms of their two sub-relations, Russia to the Caucasus states and the Caucasus states to Russia. The Caucasus states were vulnerable to the greater capacity of Russia, and therefore they were more attentive to these relations.

Another factor on relations between the Caucasus states and Russia was influenced by the domestic conditions of the Caucasus states. The Caucasus statesRussian relations were determined more often depending on domestic political actors and conditions of these countries than by geopolitical calculation in the 1990s. Therefore, the Caucasus states-Russian relations also changed based on domestic political circumstances. Particularly, the level of state strength in the Caucasus affected the outcome of these relations. For example, Azerbaijan and Georgia did not have stable and strong state institutions, and for that reason their foreign policies were affected negatively. Russia easily pressured them to accept its dominance in the region. Most of the foreign policy activities in the Caucasus during the 1990s were concerned with the internal strength of states which were carried out under the pretext of security against internal and external threats. Thus, the concepts of strength, security and asymmetrical relations between the Caucasus states and Russia became two fundamental characteristics underlying the foreign policy-behavior of the Caucasus states.

Moreover, leaders of the Caucasus states considered both internal and external threats not only to their states but also to their regimes. When they responded to these threats, they tackled first the vital security threats to their leadership. Thus, their foreign 
policies were also formed as a product of perceived threats to their leaderships. The leaders of the Caucasus states did not separate the foreign policy process from other governmental activities. As a result, they considered foreign policy as a tool for interaction between power struggles in domestic politics and position in the international system.

Armenia bandwagoned with Russia because the Armenian leadership perceived Turkey and Azerbaijan as the main external threats. To deflect Turkish and Azerbaijani threats, Armenia bandwagoned with Russia and accepted all of Russia's demands, such as having military bases and guarding Armenian borders with Iran and Turkey. Armenia was the exceptional case in the Caucasus for several reasons: first, Armenia is ethnically the most homogenous state and does not have a border with Russia. Second, Armenia considers Turkey and Azerbaijan as the main external threats, not Russia. So, the Armenian governments considered Russia as a balancing power and they bandwagoned with Russia to deal with potential threats which they assume come from neighboring countries. On the other hand, nationalist leaders, Gamsakhurdia and Elchibey, respectively in Georgia and Azerbaijan, looked for alternative choices to reach their goals to challenge Russian dominance in the region in the early 1990s. Because of their 'closed mind ${ }^{730}$ toward Russia, they interpreted all Russian actions in the region in a manner to reinforce their perception of Russia as the main threat for their countries. Therefore, characteristics of the leaders of the Caucasus states had often decisive impacts on the foreign policies their countries in the 1990s. Nationalist leaders pursued foreign policy to keep their countries away from Russian influence. Even though they did not receive any substantial external support and internally their leaderships were challenged, they did not

\footnotetext{
${ }^{730}$ Holsti used for Dulles, see, p. 48.
} 
change their foreign policy orientation. They continued to see Russia as the main threat and blamed Russia for supporting internal oppositions to overthrow their regimes.

In contrasts to Gamsakhurdia and Elchibey, self-oriented leaders, Shevardnadze and Aliyev asked Russia to back their regimes and provide resources to cope with immediate internal threats. Aliyev and Shevardnadze's political experience in the Soviet political structure taught them how to handle Russia and make them understand the way Russian the political machine works. Moreover, these leaders also learnt from the experience of previous leaders, Elchibey and Gamsakhurdia, that survival of their regimes depended on Russian reaction and that they did not have any available ally to support their regimes and deter to Russia from dominating the region. So, they did not have any alternative but to omnibalance with Russia. In fact, when Azerbaijan and Georgia had vitally dangerous crises in 1993 and 1994, realignment with Russia prevented these countries from total collapse. Therefore, Aliyev and Shevardnadze omnibalanced with Russia to deal with more immediate threats coming from internal sources in the early 1990s. Aliyev and Shevardnadze both realized that without strengthening their positions in their countries and securing international support, they could not stop Russia from becoming involved in their countries' domestic politics and threatening their regimes.

However, in the second half of the 1990s, U.S. involvement in the region increased as a consequence of the Caspian oil deal in 1994. As rational leaders, Aliyev and Shevardnadze attempted to maximize their benefits from American involvement in the oil project for the region. Therefore, the shifting American foreign policy in the region became an essential factor for Azerbaijan and Georgia as they redefined their 
relations with Russia. The risks and costs of challenging Russian involvement in their domestic and foreign policies were now minimized. As a result, Azerbaijan and Georgia also shifted their foreign policies from omnibalancing to Russia to being allied with the United States. Shifting of allegiances provided greater flexibility both for the leaderships and for their countries to develop their own foreign policy because the United States lacked the kind of leverage on their domestic politics that Russia had as the ex-imperial power. In other words, increased interests and involvement of the United States in the region directly affected the foreign policy orientations of both Azerbaijan and Georgia in the second half of the 1990s. They shifted their foreign policy orientation from omnibalancing to Russia to having the United States balance Russian dominance in the region. 


\section{Chapter V}

The Caucasus states-Russia relations were quite complicated in the 1990s. A variety of factors impacted on the Caucasus states' relations with Russia. The significance of the Caucasus states' relations with Russia depended greatly on the level of weakness of these states, types of threats, level of external involvement as well as the personal preferences of the Caucasus leaders in the 1990s.

Comparing different states' foreign policies requires knowing the type of state involved and the type of issues with which the states deal. In this dissertation, states are divided into two types: strong and weak. The Caucasus states were weak states during the 1990s. Because of lack of statehood experience, all Caucasus states had feared losing their independence and had tried to build their state institutions at the same time.

Among the Caucasus states, the weakest one was Georgia. Georgia had two ethnic-based conflicts (Abkhazian and South Ossetian conflicts) and one civil war between two main political fractions (Shevardnadze's government forces and Gamsakhurdia's forces) as well as several assassination attempts on the president's life in the 1990s. Moreover, Georgia was more open to external manipulation such as the Russian political and military assistance to rebellious ethnic and political groups. Compared to Georgia, Azerbaijan was stronger but it was relatively weaker than Armenia. The reason is that Azerbaijan had to deal with an ethnic war against Armenia and Armenian-populated Karabagh as well as political turmoil between different political fractions. However, Azerbaijan has significant hydrocarbon reservers to attract external attention and involvement. Even compared to Azerbaijan and Georgia, Armenia had 
relatively stronger state because of internal stability and cohesion; however, it was still a weak state. Armenia was considered a weak state because the survival of its statehood depended on external assistance; moreover, an incomplete process of state-building and weakness of state institutions gave leaders the opportunity to accumulate power. This condition created a delicate condition in the country.

Therefore, the last one and half decades of politics in the Caucasus states has been dominated by the question of survival and the process of state-building. These processes began prior to the collapse of the Soviet Union. Some of the post-Soviet states completed these processes (the Baltic states) but some of the post-Soviet states did not (the Caucasus and Central Asian states). On the one hand, the Baltic states, which existed as states between 1919-1939, have established strong state institutions and created a stable state and political life. On the other hand, the Caucasus and Central Asian states, which do not have a real political legacy of statehood, except briefly for the Caucasus states between 1918-1921, did not have viable state institutions capable of controlling and administering territory. Moreover, the Baltic states, backed by major powers in Europe and the United States, are balancing successfully to maintain independence from Russian domination. Therefore, lack of statehood experience and external support exercised substantial influence upon both the internal stability of the Caucasus states and the patterns of relations between these states and their neighbors, especially their relations with Russia.

Moreover, the Caucasus has been one of the regions most affected by ethnic conflicts. Even compared to the Balkans, the Caucasus region is more ethnically, nationally and culturally divided. The four major conflicts- Karabagh, South Ossetia, Abkhazia and Chechnya- are all characterized by ethno/national-based autonomous 
regions of the Soviet era revolting against their respective central governments during and after the fall of the Soviet Union. This ethnic diversity, so characteristic of the Caucasus, when added to the general characteristics of weak states and limited external assistance, frames the orientation of the Caucasus states' foreign policies. Thus, for the Caucasus states, the principle 'foreign policy begins at home' was relevant to understand and explain the Caucasus states' foreign policy orientation in the 1990s.

As a result, domestic conflicts were the most vital foreign policy issues of the Caucasus states in the 1990s. The reason was that domestic conflicts created vital threats for statehood and prevented these states from developing their state institutions. Therefore the domestic threat was far more important than the external one for these states. For example, the foreign policies of Azerbaijan and Georgia in the early 1990s had been dominated by the priorities emanating from dealing with threats from internal sources. In addition to that the conflict between neighboring states, for example, Armenia and Azerbaijan, could also be explained to a large degree by state-building processes which these states undertook at the same time. Armenia had claims on Azerbaijani territory where ethnic Armenians were the majority and successfully extended its control over territories and populations at the expense of its neighbor. Such state-building activity was usually responsible for bringing states into conflict with each other and feeding their perception that their minorities and/or neighbors were the principal source of threat to their security.

After the end of the Cold War, the U.S., as the global power, wanted to extend its influence beyond the traditional spheres (to Eastern Europe and the Balkans). However, the Caucasus was not on the American policymakers' agenda in the early 1990s. They 
did not consider the Caucasus as sufficiently important and preferred to leave the region under Russian influence. This was changed in the middle of the 1990s and for two reasons: first, Russia became assertive and nationalist; second, the Caspian oil reserves became an attractive alternative for the U.S. to unstable Middle East oil and gas reserves. So these developments created opportunities for the Caucasus states and their leaders.

Thus, in the second half of the 1990s, when the U.S. became involved in the regional politics of the Caucasus, Azerbaijan and Georgia shifted their alignment from Russia to the U.S. There were several reasons for this: first, both Aliyev and Shevardnadze secured their leadership and eliminated all potential competitors within their countries; second, because they eliminated internal threats, Russian influence in their countries became the main potential external threat to them. They now believed that the U.S. had capabilities to balance Russian intentions and influence and to influence outcomes of their relations with Russia in the region. In sum, Azerbaijan and Georgia first allied against internal threats rather than against external threats Russia because they realized that they were incapable of containing the Russian threats. However, when another major power (actually global power), the U.S., became involved in regional politics, Azerbaijan and Georgia balanced against Russia when the U.S. backed them in the second half of the 1990s.

Thus, the Caucasus states responded to utilize both their geopolitical and geoeconomic condition as well as the rivalry of the major powers to secure survival, aid, and arms from the major powers. Thus, in the second half of the 1990s, Azerbaijan and Georgia were enabled to have a more flexible foreign policy to maintain their sovereignty against Russia. In sofar as a regional system formed around the Caucasus in response to 
Russia's declining power and the arrival of major Western oil corporations in the second half of the 1990s, the bargaining potential of the Caucasus states, especially Azerbaijan (with its oil and gas reserves) and Georgia (with its strategic location along the BakuTbilisi-Ceyhan pipeline), increased significantly.

Another factor was the role of leaders in the Caucasus. The role of leadership in the Caucasus was variably linked with the foreign policy-making environment and foreign policy-behavior. The Caucasus leaders perceived reality differently because of their differing orientations, interests, and belief systems. Therefore, the perception and actions of the Caucasus leaders constructed the ways in which they saw the reality and their position both in domestic and internal political structures. In addition, because foreign policy is a crucial element for leadership security, the leaders of these countries fully controlled and managed the foreign policy-making process and were involved in all the stages of foreign policy. Thus, their characters, beliefs, and perceptions of the international system shaped their countries' foreign policies.

Two types of leadership have helped us to understand the role of leaders in the foreign policy processes of the Caucasus states: nationalist and self-interest leadership models, respectively.

Nationalist leaders came to power in the Caucasus in the early 1990s. The nationalist-oriented leaders acted according to the titular nationality's feelings in their countries. For example, the relations between the Caucasus states and the ex-imperial center, Russia, were an important area for testing the abilities and flexibilities of the nationalist-oriented leaders. 
The nationalist leaders, such as Elchibey and Gamsakhurdia, considered internal threats to their regimes as stemming from the ex-imperial center, Russia and its policies so they took actions to balance Russian influence/involvement on these internal conflicts, such as when both Elchibey and Gamsakhurdia rejected making their countries members of the CIS and both requested Russian forces to leave their countries. These nationalist leaders thus had a fixed goal for their foreign policy orientation. They considered Russia as the number one threat without really considering their own weaknesses or crisis conditions. In other words, they perceived a single-minded policy and for them it was difficult to change their foreign policy directions based on circumstances.

Therefore, believing that Russia produced the problems in their countries, they divided their foreign policy goals into two important elements: they considered Russia as an actual enemy in the Georgian case or a potential threat in the Azerbaijani case. Therefore, they developed their foreign policy to deal with these real or potential threats. They pursued anti-Russian alliance policies, even though the structural and political conditions in the region were not suitable for their policies. As a result, these nationalist leaders' beliefs and perceptions provided a direction for charting their foreign policies.

Self-interest oriented leaders in weak states are quick to take advantage of the opportunities arising from the international and regional system as well as domestic conditions of their states and major powers. They learn to manipulate the competition between major and regional powers for their own ends, and in this way they have a considerable influence, even if not always a critical one, on the region itself. The selfinterested leaders know how to use the weakness of their states to their advantage. They have also learned to manipulate the strength of the global and regional powers in their 
own personal interests. For example, self-oriented leaders in the Caucasus such as Aliyev and Shevardnadze concentrated on establishing their authority in their respective countries. When they chose certain foreign policy options to respond to immediate threats, they first acted to secure their own personal security. For example, both Aliyev and Shevardnadze, when they were struggling to deal with powerful domestic oppositions, approached Russia even though their countries' public opinions did not share the same opinion for their choices; these leaders did consider Russia as a threat but as a secondary threat. They accepted some Russian demands, such as when both Azerbaijan and Georgia joined the CIS. Therefore, these leaders in the Caucasus practiced a balancing act and were often supported in this by external actors.

Nevertheless, both nationalist and self-oriented leaders in the region considered foreign policy as a tool to deal not only with external but also internal threats. However, there were clear differences between the nationalist leaders from the self-oriented leaders in the Caucasus on perceiving threats. Moreover, because of the weakness of state institutions and effective lack of checks and balances, the leaders of the Caucasus states were less constrained in implementing their countries' foreign policy. As a result, the personalities of the leaders of the Caucasus became important variables in analyzing these states' foreign policies.

Threats to survival of states and their leaders were the main foreign policy issues for these states in the 1990s. They had difficulty in defending themselves against a strong state, such as Georgia against Russia, against a single weak state, such as Azerbaijan against Armenia, or even internal opposition groups, such as Kitovani's and Huseyinov's paramilitary groups. Therefore, dealing with these threats coming from internal and 
external sources became the most vital issues of the foreign policy process. When they confronted internal or external threats, their internal strengths were usually not sufficient to deal with these threats. Under such circumstances, the Caucasus states turned to external sources for assistance.

Mainstream realist scholars, such as Waltz, Walt, and Schweller, agree that weak states, such as the Caucasus states, are more likely to bandwagon than to balance because they have limited ability to influence on the outcomes of systemic changes and no power to balance a strong challenger. However, the mainstream IR theories can not adequately explain omnibalancing behavior among weak states taking into account the type of threats facing weak states, roles played by individual leaders as well as the nature and origin of external support. For these reasons, the weak states' foreign policies were shaped and led by individual leaders. Therefore, personal characteristics and orientations of leaders played a significant role in foreign policy direction. For example, the first president of Azerbaijan, Mutalibov was very loyal to Russia. He pursued an omnibalancing policy against internal opposition. He was expecting Russian assistance to deal with internal conflicts. The second president of Azerbaijan, Elchibey abandoned Mutalibov's policy on Russia, balanced the Russian influence with Turkey and inclined towards the Western world in general. Elchibey asked Russia to close all former Soviet military bases and withdraw the Russian military forces from Azerbaijan. He also excluded Russian oil companies from the international consortium which was established to exploit Azerbaijani oil. Therefore, there was tension between Azerbaijani and Russia during the Elchibey's tenure. The overthrow of the Elchibey regime in July 1993 and his replacement by Aliyev were, at the beginning, of benefit to Russia. Despite considerable 
popular opposition in Azerbaijan, one of the first foreign policy actions of the Aliyev government was to improve relations with Moscow. Aliyev hoped that Russia would help resolve the Karabagh conflict in a way favorable to Azerbaijan. It became clear, however, that the joining of Azerbaijan to the CIS would not satisfy Russia, which soon revealed that Russia had other demands. Therefore, under similar circumstances, such as the worsening condition in Karabagh, Elchibey and Aliyev followed different paths. Elchibey refused to ask assistance from Russia, while on the other hand, Aliyev asked Russia to mediate between Azerbaijan and Armenia to stop the war.

In another example, the survival of Gamsakhurdia's regime was challenged by both external and internal threats. Therefore, because of the nature of threats to his regime, his government should have bandwagoned with Russia, according to realists. However, instead of developing close relations with Russia, he continued to see Russia as the main threat and looked for alternative powers to assist his regime. The reason is that he, as a nationalist leader, considered Russia as the ex-imperial center and thus inherently threatening.

On the other hand, Shevardnadze believed the risk would be greater if he did not cooperate with Russia, given Georgia's threatened disintegration, the weakness of its government, and the disinterest of the western major powers in the Caucasus. He had become dependent on Russia for his political and personal safety in the early 1990s. In exchange for the Russian military assistance, Shevardnadze was forced to accept increased Russian influence and presence in Georgia. Shevardnadze's move can be characterized as omnibalancing because he was trying to appease the secondary threat, Russia, in order to allay the primary threat of internal disintegration and to ensure his 
own political survival. Thus, he was careful to balance both internal players and external major powers. While recognizing the need to maintain good relations with Russia to stay in power, he emphasized the need to seek out alternative relations particularly with the United States, neighboring Turkey, and Azerbaijan in order to provide a necessary balance.

Therefore, there were three different positions in which the Caucasus states found themselves having relations with Russia in the international and regional systems: they could balance with help of another major power, such as the U.S., or under a loose regional system, such as GUAM, or bandwagon with Russia, or they could omnibalance with Russia against major internal threats to their leaderships. The first was a situation in the second half of 1990s in which the Caucasus states, Azerbaijan and Georgia, had enjoyed relative freedom of maneuver and action. They aligned with the U.S. The second was one wherein Armenia bandwagoned with Russia; Armenia therefore had little or no freedom for having an independent foreign policy. Armenia could not align itself with other states. Armenia was excluded from the international system because Armenia was under the control of Russia that declared Armenia to be part of its sphere of influence. The third case was one in which leaders of the Caucasus states omnibalanced against both external and internal threats to their leaderships. Thus, when the primary threat was internal, the self-oriented leaders of Azerbaijan and Georgia aligned with Russia to get resources to deal with the internal oppositions, such as Russian assistance to Shevardnadze against Gamsakhurdia’s supporters.

In conclusion, under greater external threats, both nationalist and self-oriented leaders of Azerbaijan and Georgia tried to balance against Russian influence with other 
major and regional powers when there were high external commitments. When there were not high external commitments, self-oriented leaders of the Caucasus (TerPetrossian, Aliyev and Shevardnadze) bandwagoned with Russia. In this way, hypotheses 1, 2. 3, and 4 are justified. However, for the Armenian case, hypotheses 1, 2, and 4 failed to explain the case. ${ }^{731}$

Under the greater internal threats, self-oriented leaders (Ter-Petrossian, Aliyev, and Shevardnadze) omnibalanced internal threats with the help of Russia. However, the national leaders of the Caucasus continued to balance against Russian influence. The exceptional case was Armenia under the Kocharian leadership. Therefore, hypotheses 5 and 7 are justified for all cases, but hypotheses 6, and 8 are applicable for the Azerbaijani and Georgian cases but not the Armenian case. ${ }^{732}$ Therefore, in the dissertation hypotheses 3, 5, and 7 apply to all Caucasus states. But hypotheses 1, 2, 4, 6, and 8 fail to explain the Armenian case.

Finally, Russian foreign policy in the Caucasus aimed toward weakening those Caucasus states and their leaders who sought to balance Russian influence and ask assistance from other major powers. Russia was unwilling to see the post-Soviet Caucasus states escape its "sphere of influence." It sought to weaken these states and leaders through coercive policies. The cases of Armenian-Russian, Azerbaijani-Russian and Georgian-Russian relations are significant examples of the patterns of influence that have been common across the Caucasus and Central Asia in the 1990s. For example, in recent years, Kyrgyz foreign policy has been trying to find a new location for itself between Russia and the United States. This is highlighted by the rental negotiations

\footnotetext{
${ }^{731}$ For hypotheses 1, 2, 3, 4 look at page 93.

${ }^{732}$ For hypotheses 5, 6, 7, 8 look at page 95.
} 
concerning the American air base as well as the expansion of the Russian air base under the umbrella of the CSTO (Collective Security Treaty Organization) in Kyrgyzstan. In addition, the Kyrgyz leaders are also aware that Kyrgyzstan is a weak state and their positions also depend on how they balance not only between the major powers but also the level of external influence on the domestic political system. It was precisely this new orientation that was being supported and reemphasized by the poster campaigns seen in the streets of Bishkek in May 2006. The billboards of the Kyrgyz capital were littered with photographs of President Bakiyev shaking hands with President Putin, Prime Minister Fradkov and Moscow Mayor Luzhkov. Given the fact that the the Kyrgyz president's Moscow visit was in April the only explanation is that these posters were aiming to develop symbols to encourage the Kyrgyz political elite to identify the Kyrgyz political leadership with Russia and demonstrated to the Kyrgyz public that Russia was supporting the current Kyrgyz leadership.

Russia wants to keep this region under its influence. As Russia gradually began to recover to formulate its long term policy toward the Caucasus, it grew increasingly concerned about the expansion of Western influence in the region. Even though Armenia is the closest ally in the region for Russia, Russia is aware that both Azerbaijan and Georgia are vitally important for Russia not just for geopolitical reasons but also geoeconomic ones so Russia cannot simply ignore their pro-Western foreign policies. Therefore, Russia prefers to utilize the Caucasus states' inability to find peace in Karabagh, South Ossetia and Abkhazia so Russia can keep its influence in the region. Thus, Russian relations with each of the Caucasus states depend on the Russian roles in the regional conflicts and Russian interests in the region. 
In conclusion, looking at foreign policy behavior from historical and domestic perspectives helped us to understand current Caucasus states' foreign policies and their relations with Russia. First, in using historical factors as variables in explaining foreign policy, we explored the extent to which historical factors in the Caucasus were compatible with political realities in the 1990s. Second, in using domestic factors as variables for explaining foreign policy, we stressed structural features of domestic regimes in the Caucasus, which constrained the foreign policy of these states, and the political orientation of the Caucasus leaders in control of these states. In this way, a close study of international and domestic developments, internal and external interactions among actors, and political issue-areas provides students of the foreign policy of the Caucasus states with a better understanding of how the interaction between domestic and external factors shapes the foreign policy processes and actions of the Caucasus states in general as well as their relations with Russia in particular.

The invasion of Georgia in August 2008 had profound repercussions on Russian relations with the Caucasus states. It is still unclear what prompted the war. Each side has accused the other. According to the Russians, the Georgians started the conflict, killing Russian peacekeepers. According to the Georgians, the Russian peacekeeping forces violated their neutrality and were engaged in actively arming the South Ossetians against Georgia. Georgia also claims that Moscow wants to take possession of the region. As evidence, Georgia indicates that Russia provided residents of South Ossetia with Russian passports so that Russia can claim it is defending its own citizens.

As a leader of a weak state, Mikhael Saakashvili has the ambition and desire to make his country part of the Western allies so Georgia can balance Russian influence in 
the region. Therefore he made joining NATO and the EU one of his top priorities. But there is disagreement among NATO members on whether to consider Georgian membership. For example, Germany preferred to avoid a confrontation with Russia. At a summit in Bucharest in April 2008, NATO members declined to set a timetable for the inclusion of Georgia. According to the NATO treaty, NATO could not include a state that had not resolved its territorial problems. The Russian government concluded that in order to prevent NATO's enlargement in the Caucasus, Russia had to prevent Georgia from solving its ethno-territorial issues. The Georgian president's conclusion, of course, was the opposite: Georgia would be able to join NATO only if it could control South Ossetia as well as Abkhazia.

Saakashvili considers that Russia is the main threat for the stability of Georgia. He believed that the U.S. and the other major Western powers would intervene, saving Georgia from annihilation and accepting Georgia into the Western security and economic system, as in NATO and the EU. Moreover, Georgia emerged as a key energy transit route, where Russia and the West are vying for influence. However, the U.S. and some of its European allies, such Germany, had different views on Georgia and Russia. For the U.S., Georgia is a very important ally in the Caucasus. However, Germany cannot sacrifice its good relations with Russia in order to save Georgia.

However, Georgia failed in preventing the destruction of the pre-war status quo. Instead, Georgia, de facto, lost Abkhazia and South Ossetia, and turned these conflicts from internal to external ones. Moreover, U.S. relations with Georgia did not deter Russia from responding to the Georgian assault on South Ossetia. This is an indication that Russia still considers former Soviet Union regions (excepting the Baltic states) as the 
sphere of influence of Russia so that Russia can use force without consulting any international body and major power. Russia is the foremost military power in the region. Even after major setbacks following the collapse of the Soviet Union, Russia still has dominant military forces in the region. It would be impossible for any of the Caucasus state alone to challenge Russian dominance in the region. The Baltic states, backed by the major powers of Europe and the U.S., were balancing successfully to secure sovereignty and maintain independence from Russian domination. Since survival was at stake for the Caucasus states, the notion that states constantly balance against threat is more than convincing. This may be in terms of internal balancing, where a state increases its own power domestically, or external balancing, where resources are pooled with other states for a specific purpose.

The real difference between weak states and strong states was that leaders of weak states used foreign policy to deal with immediate internal threats to their political regimes. Thus, this dissertation has explained how the Caucasus weak states incorporated balancing and bandwagoning policies against external threats and omnibalancing policy against internal threats. Therefore, it is simply not true that the realist motto, "the strong do what they will, while the weak suffer what they must" holds for the weak states. It is true that the security of weak states does suffer from their greater sensitivity and vulnerability but still their foreign policy was directed by their leaders' perception on the international system and the place of their states in this system.

Consequently, there are two stories in this foreign policy analysis: understanding foreign policy-making and explaining foreign policy-behavior. Two-level models looking at domestic variables as well as external ones help us to understand the Caucasus states' 
foreign policy processes. The understanding of the foreign policy orientations of the Caucasus states in general and their relations with Russia in particular, provides us with the prospect of explaining relations between the Central Asian states and Russia as well as relations between post-imperial (as well as post-communist and post-cold war) weak states and a former imperial center and/or regional power. 


\section{Bibliography}

\section{$\underline{\text { Interviews }}$}

Arman Kirakossian, Ambassador of Armenia to the United States, 25 April 2002.

Gerard J. Libardian, Former Presidential Advisor and First Deputy Foreign Minister of Armenia, 11 December 2000.

Hafiz Pashayev, Ambassador of Azerbaijan to the United States, 11 December 2000.

Tofiq Zulfiqarov, Former Foreign Minister of Azerbaijan, 11 December 2000.

Araz Azimov, Deputy Foreign Minister of Azerbaijan, 01 January 2006.

Elshad Nassirov, Vice President of SOCAR, 03 January 2006.

Tedo Japaridze, Ambassador of Georgia to the United States, Canada, and Mexico, 30 November 2001.

David Soumbadze, Senior Counselor, Embassy of Georgia, 30 November 2001.

Richard Kauzlaurich, Former Ambassador of the United States to Azerbaijan, 11

December 2000.

Stanley T. Escudero, Former Ambassador of the United States to Azerbaijan, 06 January 2006.

Laurie Bristow, British Ambassador to Azerbaijan, 03 January 2006.

Romualds Razuks, NATO Liason Officer in the Caucasus, 04 January 2006.

\section{Governmental Documents}

Congressional Hearing Before the Committee On International Relations, House of Representatives, 105 Congress, Second Session, 30 April 1998 "The U.S. Role in the Caucasus and Central Asia".

http://commdocs.house.gov/committees/intlrel/hfa50308.000/hfa50308_0f.htm

Freedom for Russian and Emerging Eurasian Democracies and Open Markets Support Act of 1992, Public Law 102-511, sec. 907, 24 October 1992.

http://uscode.house.gov/download/pls/22C67.txt 
The Constitution of Armenia

http://www.president.am/library/constitution/eng/

The Constitution of Azerbaijan

http://www.president.az/

The Constitution of Georgia

http://www.mfa.gov.ge/files/37 57 318646_constitutiont.pdf.

\section{International Documents}

United Nations Security Council Resolutions,

www.un.int/azerbaijan,

www.un.int/armenia,

www.un.int/georgia.

OSCE/ODIHR (Office for Democratic Institutions and Human Rights) webpage, www.osce.org/odhir_elections/14207.html.

International Foundation for Electoral Systems webpage, www.electionguide.org/.

\section{Secondary Sources}

Abdelal, Rawi; 2001, National Purpose in the World Economy: Post-Soviet States in Comparative Perspective, Ithaca: Cornell University Press.

Abdullayeva, Sevindzh, and Viktor Shulman; 1997, “Aliyev Welcomes Proposals of Minsk Group Co-Chairmen,” ITAR-TASS, 7 October.

Acar, Dilaver A., and Inan Ruma; 2007, "External Pressure and Turkish Discourse on 'Recognition of the Armenian 'Genocide,' 'Southeast European and Black Sea Studies, September, vol. 7, no. 3 .

Adler, Emanuel; 1997, "Seizing the Middle Ground: Constructivism in World Politics," European Journal of International Relations, vol. 3.

Agacan, Kamil; 2001, “Bagimsizliginin 10.Yilinda Gurcistan: ABD’nin Kafkasya'daki Kalesi mi? ” Stratejik Analiz, cilt 1, sayi 11.

Airapetova, Natalya, and Armen Saakyan; 1997, "Yeltsin and Ter-Petrosyan Sign Friendship Treaty: Document Opens New Stage of Strategic Partnership Between Moscow and Yerevan," Nezavisimaya Gazeta, 30 August. 
Aliev, Dimitry, and Georgy Bovt; 1995, “Turkish Prime Minister's Foreign Tour: Given the Political Will," Kommersant, 12 July.

Alieva, Leila; 2000, "Reshaping Eurasia: Foreign Policy Strategies and Leadership Assets in the Post-Soviet South Caucasus, ” Berkeley Program in Soviet and Post-Soviet Studies, Working Paper Series, University of California, Berkeley, Winter.

Allison, Graham T.; 1971, The Essence of Decision, Boston: Little Brown, 1971. , and Morton H. Halperin; 1972, "Bureaucratic Politics: A Paradigm and Some Policy Implications," in Theory and Policy in International Relations, Raymond Tanter and Richard H. Ullman eds., Princeton: Princeton University Press. , and Philip Zelikow, 1999, Essence of Decision: Exploring the Cuban Missile Crisis, $2^{\text {nd }}$ ed., New York: Longman.

Allison, Roy; 1996, Challenges for the Soviet South, Washington, D.C.: Brookings Institution Press.

; 1996, "Military Factors in Foreign Policy," in Internal Factors in Russian Foreign Policy, Neil Malcolm, et al., eds., Oxford: Oxford University Press. , and Christoph Bluth; eds., 1998, Security Dilemmas in Russia and Eurasia, London: The Royal Institute of International Affairs. ; 1999, "The Military and Political Security Landscape in Russia and the South," in Russia, the Caucasus, and Central Asia: The $21^{\text {st }}$ Century Security Arrangement, Rajan Menon, et al., eds., Armonk: M.E. Sharpe.

Almond, Mark; 1995, Russia's Outer Rim: Integration or Disintegration? London: Institute for European Defence and Strategic Studies.

Altstadt, Audrey L.; 1992, The Azerbaijani Turks: Power and Identity under Russian Rule, Stanford: Hoover Institution Press. ; 1997, “Azerbaijan's Struggle Toward Democracy," in Conflict, Cleavage, and Change in Central Asia and the Caucasus, Karen Dawisha and Bruce Parrott, eds., Cambridge: Cambridge University Press.

Ambrosio, Thomas; 2000, "Acquiring Friends and Allies in Ethnic Conflicts: The Armenian-American Lobby and U.S. Involvement in the Nagorno-Karabakh War, ” a paper presented at the 2000 Annual Meeting of the American Political Science Association. 
; 2000, "Entangling Alliances: The Turkish-Israeli Lobbying

Partnership and Its Unintented Consequences," in Ethnic Identity Groups and U.S.

Foreign Policy, Thomas Ambrosio, ed., Westport: Praeger.

; 2001, Irredentism: Ethnic Conflict and International Politics,

Westport: Praeger.

Amineh, Mehdi P.; 1999, Towards the Control of Oil Resources in the Caspian Region,

New York: St. Martin's Press.

Amrahgizi, Elmira, and Betty Blair; 1997, "Diplomatic Interview Vafa Guluzade:

Foreign Policy Advisor to Azerbaijan's President," Azerbaijan International, Spring, vol.

5 , no. 1 .

Anderson, Paul A.; 1987, “What Do Decision Makers Do When They Make a Foreign Policy Decision?" in New Directions in the Study of Foreign Policy, Charles F.

Hermann, Charles W. Kegley, and James N. Rosenau, eds.,Boston: Allen \& Unwin.

Antonenko, Oksana; 2004, "Russia's Policy in the Caspian Sea Region: Reconciling Economic and Security Agendas," in The Caspian: Politics, Energy, and Security, Shirin Akiner, ed., London: Routledge Curzon.

Arbatov, Alexei; 1993, “Russia's Foreign Policy Alternatives," International Security, vol. XVIII, no. 2.

Areshidze, Irakly; 2007, Democracy and Autocracy in Eurasia: Georgia in Transition, East Lansing: Michigan State University Press.

Aron, Leon; 1994, "The Emergence Priorities of Russian Foreign Policy," in The Emergence of Russian Foreign Policy, Leon Aron and Kenneth M. Jensen, eds., Washington, D.C.: United States Institute of Peace Press.

; 1998, "The Foreign Policy Doctrine of Postcommunist Russia and Its

Domestic Context," in The New Russian Foreign Policy, Michael Mandelbaum, ed., New

York: A Council on Foreign Relations Book.

Aslan, Yasin; 1993, “Soviet Game in Azerbaijan," Yeni Forum, July.

Aslanli, Araz; 2001, "Kuresel ve Bolgesel Aktorlerin Son Girisimleri Isiginda Karabag Sorunu: Cozume Dogru ти?” Stratejik Analiz, cilt 1, sayi 12.

Astourian, Stephan H.; 2000-2001, 'From Ter-Petrosian to Kocharian: Leadership Change in Armenia," Berkeley Program in Soviet and Post-Soviet Studies, Working Paper Series, Winter. 
Aves, Jonathan; 1993, Post-Soviet Transcaucasia, London: Royal Institute of International Affairs.

; 1995, "National Security and Military Issues in the Caucasus: The Causes of Georgia, Azerbaijan, and Armenia," in State Building and Military Power in

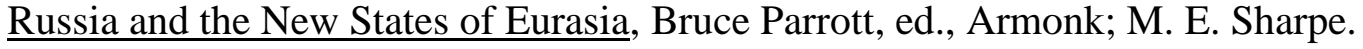

of International Affairs.

; 1996, Georgia: From Chaos to Stability?, London: The Royal Institute ; 1996, "Politics, Parties and Presidents in Transcaucasia," Caucasian Regional Studies, no. 1, http://poli.vub.ac.be/publi/crs/eng/0101-02.htm.

; 1998, “The Caucasus States: The Regional Security Complex," Security Dilemmas in Russia and Eurasia, Roy Allison and C. Bluth, eds., London: Royal Institute of International Affairs.

Ayoob, Mohammed; 1995, The Third World Security Predicament: State-making, Regional Conflict, and the International System, Boulder: Lynne Rienner Publishers, Inc.

Babbie, Early; 1995, The Practice of Social Research, $7^{\text {th }}$ ed., Belmont: Wadsworth.

Baev, Pavel; 1997, Russia's Policies in the Caucasus, London: The Royal Insitute of International Affairs.

; 2001, Russia Refocuses its Policies in the Southern Caucasus, Harvard University, Caspian Studies Program, Working Paper Series, July, no. 1.

Bagirov, Sabit; 2001, “Azerbaijan's Strategic Choice in the Caspian Region,” in The Security of the Caspian Sea Region, Gennady Chufrin, ed., Oxford: Oxford University Press.

Baillie, Sasha; 1998, “A Theory of Small State Influence in the European Union,” Journal of International Relations and Development, August.

Bal, Idris; 2000, Turkey's Relations with the West and the Turkic Republics: The Rise and Fall of the 'Turkish Model', Aldershot: Ashgate, 2000.

Baldwin, David A.; 1993, ed., Neorealism and Neoliberalism: The Contemporary Debate, New York: Columbia University Press.

Baran, Zeyno; 2002, “The Caucasus: Ten Years after Independence,” The Washington Quarterly, vol.25, no.1. 
;2004, "Turkey and the Caucasus," in Turkish Foreign Policy in Post Cold

War Era, Idris Bal, ed., Boca Raton: Brown Walker Press.

Barber, James D.; 1992, Presidential Character: Predicting Performance in the White House, $4^{\text {th }}$ ed., Englewood Cliffs: Prentice Hall.

Barkey, Karen and Mark von Hagen, eds.; 1997, After Empire: Multiethnic Societies and Nation-building: The Soviet Union and the Russian, Ottoman, and Habsburg Empires, Boulder: Westview Press.

Barylski, Robert V.; 1995, "Russian, the West, and the Caspian Energy Hub," The Middle East Journal, Spring, vol. 49, no. 2.

Bauwens, Werner; Armand Clesse and Olav F. Knudsen, eds.; 1996, Small States and the Security Challenge in the New Europe, London: Brassey's.

Beasley, Ryan K., Juliet Kaarbo, the others, eds.; 2002, Foreign Policy in Comparative Perspective: Domestic and International Influences on State Behavior, Washington, D.C.: CQ Press.

Beebe, George Standish; 1994, Russia's Approach to Instability in the Near Abroad: A Case Study of the South Ossetian and Abkhazian Conflicts, Master thesis at the University of Virginia.

Beissinger, Mark R., and Crawford Young, eds.; 2002, Beyond State Crisis? Postcolonial Africa and Post-Soviet Eurasia in Comparative Perspective, Washington, D.C.: Woodrow Wilson Center Press.

Bennett, Andrew; 1999, Condemned to Repetition?: The Rise, Fall, and Reprise of Soviet-Russian Military Interventionism, 1973-1996, Cambridge, MA: MIT Press.

Bercovitch, Jacob; 1984, Social Conflict and Third Parties: Strategies of Conflict Resolution, Boulder: Westview.

Bertsch, Gary K., Cassady Craft, Scott A. Jones and Michael Beck, 2000, Crossroads and Conflict: Security and Foreign Policy in the Caucasus and Central Asia, New York: Routledge.

Bhatty, Robin and Rachel Bronson; 2000, "NATO's Mixed Signals in the Caucasus and Central Asia," Survival, vol.42, Autumn.

Birch, Julian; 1995, “Ossetia: A Caucasian Bosnia in Microcosm,” Central Asian Survey, vol. 14 , no. 1 .

Birgerson, Susanne M.; 2002, After the Breakup of a Multi-ethnic Empire: Russia, Successor States, Eurasian Security, Westport: Praeger. 
Blair, Betty; 1995, "Diplomatic Interview: American Embassy, Richard Kauzlerich," Azerbaijan International, Autumn, vol. 3, no. 4.

Blank, Stephen; 1995, “Energy and Security in Transcaucasia,” Problems of PostCommunism, July/August, no. 16-17.

Bolukbasi, Suha; 1997, “Ankara's Baku-Centered Transcaucasia Policy: Has It Failed?” Middle East Journal, vol. 51, no. 1.

Borovali, Fuat; 1992, "The Caucasus within A Historical-Strategic Matrix: Russia, Iran and Turkey," RFE/RL Research Report, 19 March.

Bovt, Georgiy; 1995, “In Politics, a Draw Often Means Victory,” Kommersant, 10 October.

Boyce, Peter J.; 1978, Foreign Affairs for New States: Some Questions of Credentials, New York: St. Martin's Press.

Braveboy-Wagner, Jacqueline Anne; 2003, The Foreign Policies of the Global South: Rethinking Conceptual Frameworks, Boulder: Lynne Rienner.

Bremmer, Ian, and Ray Taras, eds.; 1993, Nation and Politics in the Soviet Successor $\underline{\text { States, }}$ Cambridge: Cambridge University Press.

vol. 8 , no. 3 . , and Cory Welt; 1997, “Armenia's New Autocrats," Journal of Democracy, , and Ray Taras, eds.; 1997, New States New Politics: Building the PostSoviet Nations, Cambridge: Cambridge University Press.

Brown, Bess; 1994, ‘Aliyev Defends Oil Deal,’ RFE/RL Daily Report, no. 183, 26 September.

Brobizheva, Leokadia, Rose Gottemoeller, and Catherine M. Kelleher, eds.; 1996, Ethnic Conflict in the Post-Soviet World: Case Studies and Analysis, Armonk: M.E.Sharpe.

Brzezinski, Zbigniew; 1994, "The Premature Partnership,” Foreign Affairs, March/April, vol. 73, no. 2.

; 1997, The Grand Chessboard: American Primacy and Its

Geostrategic Imperatives, New York: Basic Books.

Bulavinov, Ilya; 1995, "Russian-Armenian Military Treaty: Russia Increases Its Military Presence in the Transcaucaucasus," Kommersant, 17 March. 
; 1995, “Result of Pavel Grachev's Visit to the Transcaucasus: Minister at the 'Point of Return,' Kommersant, 25 March.

Burke, Adrian W.; 2000, "Pipeline Politics: U.S. Corporations Lead Foreign Economic Policy, " Journal of South Asian and Middle Eastern Studies, vol.24, no.1, Fall.

Buszynski, Laszek; 1996, Russian Foreign Policy after the Cold War, Westport: Praeger.

Buzan, Barry; 1991, People, States \& Fear: An Agenda for International Security Studies in the Post-Cold War Era, $2^{\text {nd }}$ ed., New York: Harvester Wheatsheaf.

Cafersoy, Nazim; 2001, Elcibey Donemi Azerbaycan Dis Politikasi (Haziran 1992-

Haziran 1993) Bir Bagimsizlik Mucadelesinin Diplomatik Oykusu, Ankara: ASAM.

Calvert, Peter; 1986, The Foreign Policy of New States, Sussex: Wheatsheaf Books.

Carlsnaes, Walter; 1986, Ideology and Foreign Policy: Problems of Comparative Conceptualization, New York: Basil Blackwell.

; 1992, "The Agency-Structure Problem in Foreign Policy Analysis,"

International Studies Quarterly, vol.36, no.3, September.

; 2002, "Foreign Policy" in Handbook of International Relations,

Walter Carlsnaes, Thomas Risse, and Beth A. Simmons, eds., London; Sage Publications.

Carment, David, and Patrick James; 1997, "Ethnic Conflict at the International Level: An Appraisal of Theories and Evidence," in Wars in the Midst of Peace: The International Politics of Ethnic Conflict, David Carment and Patrick James, eds., Pittsburgh:

University of Pittsburgh Press.

Celik, Yasemin; 1999, Contemporary Turkish Foreign Policy, Westport: Praeger.

Checkel, Jeffrey; 1998, "The Constructivist Turn in International Relations Theory," World Politics, vol. 55.

Cherniavskii, Stanislav; 2000, "The Caucasian Track of Russia's Foreign Policy," International Affairs: A Russian Journal of World Politics, Diplomacy and International Relations, vol.46, no.5. ;2001, "Azerbaijan: The Caspian Sea Negotiations,"

International Affairs: A Russian Journal of World Politics, Diplomacy and International Relations, vol.47, no.2.

Chichkin, Aleksey; 1995, "Implications of Caspian Oil Route Examined", Rossiyskaya Gazeta, 21 October. 
Chufrin, Gennadii I., ed.; 2001, The Security of the Caspian Sea Region, Oxford: SPRI, Oxford University Press.

Clapham, Christopher; 1977, "Comparative Foreign Policy and Developing States," in Foreign Policy Making in Developing States: A Comparative Approach, Christopher Clapham and William Wallace, eds., Westmead: Saxon House.

of Wisconsin Press. ; 1985, Third World Politics: An Introduction, Madison: University

Clark, Susan L.; 1994, "Russia in Peacekeeping Role," in The Emergence of Russian Foreign Policy, Leon Aron and Kenneth M. Jensen, eds., Washington, D.C.: United States Institute of Peace Press.

Clarke, Douglas; 1995, "The Russian Military Presence in the 'Near Abroad'," OMRI Program Brief, 27 September.

Clines, Francis X.; 1989, "Clamor in the East; Moscow Protests to U.S. over 'Interfering' on Armenia by a Senate Panel," New York Times, 20 November.

Cohen, Jonathan; 2002, "Regional Introduction: Struggling to Find Peace," in Searching for Peace in Europe and Eurasia: An Overview of Conflict Prevention and Peacebuilding Activities, Paul Van Tongeren, et al, eds., Boulder: Lynne Rienner Publisher.

Collins, Kathleen; 2006, Clan Politics and Regime Transition in Central Asia, Cambridge: Cambridge University Press.

Cooppieters, Bruno, Alexei Zverev and Dmitri Trenin; 1998, Commonwealth and Independence in Post-Soviet Eurasia, London: Praeger.

Cornell, Svante E.; 1997, "Undeclared War: The Nagorno-Karabakh Conflict Reconsidered," Journal of South Asian and Middle East Studies, Summer, vol. 20, no. 4.

; 1998, "Turkey and Conflict in Nagorno Karabakh: A Delicate

Balance," Middle East Studies, January, vol. 34, no. 1.

; 2001, Small Nations and Great Powers: A Study of Ethnopolitical

Conflict in the Caucasus, Surrey: Curzon.

; 2001, “Democratization Falter in Azerbaijan," Journal of

Democracy, April 2001, vol.12, no.2.

Cox, Caroline; 1997, "Nagorno-Karabakh: Forgotten People in a Forgotten War," Contemporary Review, January, vol. 270, no. 1572. 
Couloumbis, Theodore A.; 1982, Introduction to International Relations: Power and Justice, Englewood Cliffs: Prentice-Hall, Inc.

Covarrubias, Amanda; 1995, “New Era for Glendale Armenians," Los Angeles Times, 08 August.

Croissant, Cynthia; 1998, Azerbaijan, Oil and Geopolitics, Commack, NY: Nova Science Publishers, Inc.

Croissant, Michael P.; 1998, The Armenia-Azerbaijan Conflict: Causes and Implications, Westport: Praeger.

, 1999, "Georgia: Bridge or Barrier for Caspian Oil," in Oil and Geopolitics in the Caspian Sea Region, Michael P. Croissant and Bulent Aras, eds., Westport: Praeger.

Cuthbertson, Ian, 1994, “The New 'Great Game', ” World Policy Journal, Winter 1994, v.11, no.4.

Cutler, Robert M., 1996, "Towards Cooperative Energy Security in the South Caucasus," Caucasian Regional Studies, no.1, 1996, http://pubs.carnegie.ru/CRS/publi/crs/eng/0101$\underline{05 . h t m}$.

Dahlburg, John-Thor; 1990, “Baku Buries Its Dead; Strike Declared to Protest Soviet Military Assault," The Associated Press, 22 January.

Darchiashvili, David; 1997, “Georgia: The Search for State Security," in Caucasus Working Papers, CISAC: Center for International Security and Arms Control, Stanford University, December 1997, http://www-leland.stanford.edu/group/CISAC/ ; 2000, "Trend of Strategic Thinking in Georgia," in Crossroads and Conflict: Security and Foreign Policy in the Caucasus and Central Asia, Gary K. Bertsch, et al., eds., New York: Routledge. ; 2005, "Georgian Defense Policy and Military Reform," in Statehood and Security: Georgia after the Rose Revolution, Bruno Coppieters and Robert Legvold, eds., Cambridge: The MIT Press.

Dauvergne, Peter, ed.; 1998, Weak and Strong States in Asia-Pacific Societies, Canberra: Allen \& Unwin.

David Carment and Patrick James; 1997, "Ethnic Conflict at the International Level: An Appraisal of Theories and Evidence", in David Carment and Patrick James, eds., Wars in the Midst of Peace: The International Politics of Ethnic Conflict, Pittsburgh: University of Pittsburgh Press. 
David, Steven R., 1991, Choosing Sides: Alignment and Realignment in the Third World, Baltimore: Johns Hopkins University Press.

vol. 43 , no. 2 . ; 1991, “Explaining Third World Alignment,” World Politics, January,

Dawisha, Adeed and Karen Dawisha, eds.; 1995, The Making of Foreign Policy in Russia and the New States of Eurasia, Armonk: M.E.Sharpe.

Dawisha, Karen; 1994, Russia and the New States of Eurasia: The Politics of Upheaval, Cambridge: Cambridge University Press.

, and Bruce Parrott, eds.; 1997, The End of Empire: The Transformation of the USSR in Comparative Perspective, Armonk: M.E.Sharpe. , and Bruce Parrott, eds.; 1997, Conflict, Cleavage, and Change in Central Asia and the Caucasus, Cambridge: Cambridge University Press.

De Raeymaeker, Omer, and et al.; 1974, Small Powers in Alignment, Leuven: Leuven University Press.

Dekmejian, R. Hrair, and Hovann H. Simonian; 2001, Trouble Waters: The Geopolitics of the Caspian Region, London: I. B. Tauris.

DeLay, Jennifer, 1999; "The Caspian Oil Pipeline Tangle: A Steel Web of Confusion," in Oil and Geopolitics in the Caspian Sea Region, Michael P. Croissant and Bulent Aras, eds., Westport: Praeger.

Desch, Michael C.; 1996, “War and Strong States, Peace and Weak States?" International Organization, Spring, vol. 50, no. 2.

Dessouki, Ali E. Hillal, and Bahgat Korany; 1984, "A Literature Survey and a Framework for Analysis," in The Foreign Policies of Arab States, Bahgat Korany and Ali E. Hillal Dessouki, eds., Boulder: Westview Press.

Devdariani, Jaba; 2003, "Georgia: Rise and Fall of Façade Democracy," Demokratizatsiya, Winter, vol. 12 , no. 1.

Deyermond, Ruth; 2008, Security and Sovereignty in the Former Soviet Union, Boulder: Lynne Rienner.

Dobbs, Michael; 1990, “Soviets Say Troops to Plan Seizure of Power," The Washington Post, 27 January.

Dogan, Yalcin; 1993, “Turkey Lost Azerbaijan,” Milliyet, 20 June. 
Dole, Robert; 1990, “Waiting Too Long to Do What's Right,” Washington Report on Middle East Affairs, May, vol. 9, no.1.

Dougherty, James E., and Robert L. Pfaltzgraff, Jr.; 1996, Contending Theories of International Relations: A Comprehensive Survey, $4^{\text {th }}$ ed., New York: Longman.

Doyle, Michael; 1986, Empires, Ithaca: Cornell University Press.

York: Norton.

; 1997, Ways of War and Peace: Realism, Liberalism and Socialism, New

Dvali, Georgy; 1998, "Signs of Chechen Connection in Attempt on Shevardnadze's Life Don't Keep Tbilisi from Seeing 'Hand of Moscow," Kommersant, 11 February.

Dzhafarov, Dzhovded; 1993, “Elchibei Doesn't Want to Return,” Nezavisimiya Gazeta, 24 June.

Eaton, Mark; 2001, "Major Trends in Military Expenditure and Arms Acquisitions by the States of the Caspian Region," in The Security of the Caspian Sea Region, Gennady Chufrin, ed., (Oxford: Oxford University Press.

Ebel, Robert and Rajan Menon; eds.; 2000, Energy and Conflict in the Central Asia and the Caucasus, Lanham: NBR: The National Bureau of Asian Research.

Eckstein, Harry; 1975, "Case Study and Theory in Political Science," in Handbook of Political Science, Fred I. Greenstein and Nelson W. Polsby, ed., Reading: AddisonWesley.

Ekedahl, Carolyn M., and Melvin A. Goodman; 1997, The Wars of Eduard Shevardnadze, (University Park: The Pennsylvania State University Press.

Elman, Colin; 1997, "Horses for Courses: Why not Neorealist Theories of Foreign Policy," Security Studies, vol. 6, no. 1.

Elman, Miriam F.; 1995, "The Foreign Policies of Small States: Challenging Neorealism in Its Own Backyard," British Journal of Political Science, 25.

Erling, Bjol; 1971, "Small States in International Politics," in Small States in International Relations, August Schou and Arne O. Brundtland, eds., New York: Wiley Interscience Division.

Ersanli, Büşra B.; 1993, "The First Years of Independence: Azerbaijan, Kazakhstan, Kyrgyzstan, Uzbekistan, Turkmenistan,” TBMM Tutanak Dergisi, vol. 34.

Evangelista, Matthew; 1989, "Issue-Area and Foreign Policy Revisited, " International Organization, Winter, vol.43, no.1. 
Evans, Peter B., Harold K. Jacobson, and Robert D. Putnam, eds.; 1993, Double-Edged Diplomacy: International Bargaining and Domestic Politics, Berkeley: University of California Press.

Fairbanks, Charles; 2001, "Disillusionment in the Caucasus and Central Asia," Journal of Democracy, vol.12, no. 4.

vol. 15 , no. 2 . ; 2004, “Georgia’s Rose Revolution,” Journal of Democracy, April,

Fawn, Rick; 2003, Realignments in Russian Foreign Policy, London: Frank Cass.

Fearon, James D.; 1991, "Counterfactuals and Hypothesis Testing in Political Science," World Politics, January, vol. 43, no. 2.

, and David D. Laitin; 2004, "Neotrusteeship and the Problem of Weak States," International Security, Spring, vol. 24, no. 4.

Felgengauer, Pavel; 1994, "Russia Strengthens Its Influence in the Transcaucasus," Sevodnya, 15 June. ; 1994, “Russian Troops Remain in Transcaucasus,” Sevodnya, 21

October. ; 1995, "The Russian Army in the Transcaucasus," Sevodnya, 25

March.

Fox, Annette B.; 1959, The Power of Small States: Diplomacy in World War II, Chicago: The University of Chicago Press.

Frankel, Joseph; 1967, The Making of Foreign Policy: An Analysis of Decision-Making, London: Oxford University Press.

Fraser, Niall, and et al.; 1990, "A Conflict Analysis of the Armenian-Azerbaijani Dispute," Journal of Conflict Resolution,_December, vol. 34, no. 4.

Frei, Daniel and Dieter Ruloff; 1989, Handbook of Foreign Policy Analysis: Methods for Practical Application in Foreign Policy Planning, Strategic Planning and Business Risk Assessment, Dordrecht: Martinus Nijhoff Publishers.

Forsythe, Rosemarie; 1996, The Politics of Oil in the Caucasus and Central Asia, Adelphi Paper, Paper 300, Oxford: Oxford University Press.

Fukuyama, Francis; 2004, “The Imperative of State-Building," Journal of Democracy, April, vol. 15, no. 2. 
; 2004, State-Building: Governance and World Order in the $21^{\text {st }}$

Century, Ithaca: Cornell University Press.

Fuller, Elizabeth; 1991, “Gamsakhurdia's First 100 Days," RFE/RL Report on the USSR, 08 March, vol. 3, no. 7.

; 1992, "The Transcaucasus: Real Independence Remains Elusive," RFE/RL Research Report, 3 January, vol. 1, no. 1.

Report, 26 June.

; 1992, “Azerbaijan after the Presidential Elections," RFE/RL Research

; 1993, "The Thorny Path to an Armenian-Turkish Rapprochement," RFE/RL Research Report, 19 March, 2, no. 12.

; 1993, “Azerbaijan's June Revolution,” RF/RL Research Report, 13

August, vol. 2, no. 32 .

; 1993, "Russia's Diplomatic Offensive in the Caucasus," RFE/RL

Research Report, 1 October, vol. 2, no. 39.

; 1993, “Eduard Shevardnadze's Via Dolorosa," RFE/RL Research

Report, 29 October, vol.2, no. 43

; 1994, "The Transcaucasus: War, Turmoil, Economic Collapse,"

RFE/RL Research Report, January, vol. 3, no. 1.

; 1994, "Iran and the Karabakh Mediation Process," RFE/RL Report, 25 February, vol. 3, no. 8.

; 1994, "Russia, Turkey, Iran and Karabakh Mediation Process," RFE/RL Research Report, 25 February, vol. 3, No. 8.

; 1996, "Azerbaijan at the Crossroads," in Challenges for the Former

Soviet South, Roy Allison, ed., Washington, D.C.: Brookings Institution Press.

; 1998, "Is Georgia Inherently Unstable," RFE/RL Newsline, 29

October 1998, vol. 2, no. 209.

; 1998, "Quotations of the Week," RFE/RL Caucasus Report, 1.

Newsline, 30 October.

; 1998, “Five Presidents Sign ‘Ankara Declaration” RFE/RL 
Gachechiladze, Revaz; 1996, "Geographical and Historical Factors of State Building in Transcaucasia," in Caucasian Regional Studies, no.1, 1996, http://pubs.carnegie.ru/CRS/publi/crs/eng/0101-03.htm ; 1998, "The Making of the New Georgia: Development FactorsPluses and Minuses," in Caucasian Regional Studies, vol. 3, no.1, 1998, http://polipc14.vub.ac.be/publi/crc/eng/030-03.htm.

Gafarly, Mekhman; 1993, "Azerbaijan: Yesterday A Rebel, Today Prime Minister- Surat Guseinov Essentially Receives Total Power," Sevodnya, 2 July.

Gambone, Michael; 2002, Documents of American Diplomacy: From the American Revolution to the Present, Westport: Greenwood Press.

Garcelon, Marc, Alexandra Wood and Enna Eskin, 1997, "Institutions, Identity, and Ethnic Conflict: International Experience and Its Implications for the Caucasus," Conference Report, Berkeley Program in Soviet and Post-Soviet Studies, Working Paper Series, University of California, Berkeley, May 2-3.

Gedda, Georgia; 1994, "Russia Backs U.S. Haiti Policy But for a Price," The Associated Press, 2 August.

Geller, Daniel S.; 1985, Domestic Factors in Foreign Policy: A Cross-National Statistical Analysis, Cambridge, MA: Schenkman Books, Inc.

George, Alexander; 1979, "Case Studies and Theory Development: The Method of Structured, Focused Comparison," in Diplomacy: New Approaches in History, Theory, and Policy, Paul G. Lauren, ed., New York: Free Press. , and Timothy J. McKeown, 1985; "Case Studies and Theories of Organizational Decision Making," in Advances in Information Processing in Organizations, vol. 2, Robert Coulam and Richard Smith, eds., Greenwich: JAI Press. ; 1993, Bridging the Gap: Theory and Practice in Foreign Policy, Washington, D.C.: United States Institute of Peace Press.

Ghazarian, Salpi H.; 1996, "Distinguishing Between Politics and Policy: An Interview with Jirair Libaridian," Armenian International Magazine, 30 June, vol. 7, no. 5-6.

Gilpin, Robert; 1981, War and Change in World Politics, Cambridge: Cambridge University Press.

Giragosian, Richard; 2001, "Nagorno-Karabagh: International Political Dimensions," in The Making of Nagorno-Karabagh: From Secession to Republic, Levon Chorbajian, ed., New York: Palgrave, 2001. 
Glaser, Charles L.; 1994/1995, "Realists as Optimists: Cooperation as Self-Help," International Security, vol. 19.

vol. 50, no. 1. ;1997, "The Security Dilemma Revisited," World Politics, October,

Gleason, Gregory; 1997, The Central Asian States: Discovering Independence, Boulder: Westview Press.

Goble, Paul A.; 1992, "Coping with the Nagorno-Karabagh Crisis," The Fletcher Forum of World Affairs, Summer, vol. 16, no. 2.

; 1993, "Ten Issues in Search of a Policy: America's Failed Approach to the Post-Soviet States," Current History, October, vol. 92, no. 576.

; 1996, "Pipelines and Pipedreams: The Geo-Politics of the

Transcaucasus, " Caspian Crossroads Magazine, 6 June.

, 1997, "Russia: Analysis from Washington-Using Minsk in the

Caucasus,” RFE/RL, 8 April.

Goldenberg, Suzanne; 1994, Pride of Small Nations: The Caucasus and Post-Soviet

Disorder, London: Zed Books.

Goldstein, Judith and Robert Keohane; 1993, Ideas \& Foreign Policy: Beliefs, Institutions, and Political Change, Ithaca: Cornell University Press.

Goltz, Thomas; 1992, “A Town Betrayed: The Killing Ground in Karabakh,” Washington Post, 8 March.

; 1998, Azerbaijan Diary: A Rogue Reporter's Adventures in an Oil-Rich, War-Torn, Post-Soviet Republic, Armonk: M. E. Sharpe.

; 2006, Georgia Diary: A Chronicle of War and Political Chaos in the PostSoviet Caucasus, Armonk: M. E. Sharpe.

Granmayeh, Ali; 2004, "Legal History of the Caspian Sea," in The Caspian: Politics, Energy and Security, Shirin Akiner, ed., London: RoutledgeCurzon.

Grigorian, Peter, 1998, "Shevardnadze Welcomes Assistance from U.S. Navy," $\underline{\text { RFE/RL }}$ Newsline, 11 September.

Grove, Andrea K.; 2007, Political Leadership in Foreign Policy: Manipulating Support Across Borders, New York: Palgrave Macmillan. 
Gulick, Edward V.; 1955, Europe's Classical Balance of Power, Ithaca: Cornell University Press.

Gultekin, Burcu; 2002, The Stakes of the Opening of Turkish-Armenian Border: The Cross-border Contacts Between Armenia and Turkey, Istanbul: French Institute of Anatolian Studies, October.

Guluzade, Vafa; 1999, Caucasus among Enemies and Friends, Baku: Oka Offset, 1999.

Gunter, Michael M.; 1986, Pursuing the Just Cause of Their People: A Study of Contemporary Armenian Terrorism, Westport: Greenwood Press, Inc.

Gurun, Kamuran; 1985, The Armenian File: The Myth of Innocence Exposed, London: K. Rustem \& Bro.

Guseinov, Elmar; 1998, “Will The Oil Pipeline Go Through Georgia?” Izvestia, 14 February.

Guseinov, Guseinov; 1994, "Battle Over the Caspian Shelf Attests to Lack of Coordination between Russian Government Departments," Izvestia, 29 September.

Haindrava, Ivlian; 2003, "Letter from Georgia: Looking beyond Shevardnadze," Problems of Post-Communism, January/February 2003, vol.50, no.1.

Hale, Henry; 1999, "Independence and Integration in the Caspian Basin," SAIS Review, $19,1$.

Hale, William; 2000, Turkish Foreign Policy 1774-2000, London: Frank Cass.

Halliday, Fred; 1995, "The Empires Strike Back? Russia, Iran and the New Republics," World Today, November.

Handel, Michael; 1981, Weak States in the International System, London: Frank Cass.

Hanrieder, Wofram F.; 1971, Comparative Foreign Policy: Theoretical Essays, New York: David McKay Company, Inc.

Haq, Farhan; 1994, "Georgia-Haiti: Did the United Nations Host a Great Power Trade?" IPS- Inter Press Service, 1 July.

Hass, Ernest B.; 1997, Nationalism, Liberalism, and Progress: The Rise and Decline of Nationalism, vol.1, Ithaca: Cornell University Press.

Helly, Damien, and Giorgi Gogia; 2005, "Georgian Security and the Role of the West," in Statehood and Security: Georgia after the Rose Revolution, Cambridge: The MIT Press. 
Henze, Paul; 2001, “The Land of Many Crossroads: Turkey's Caucasian Initiatives,” Orbis: A Journal of World Affairs, vol.45, no.1, Winter.

Heradstveit, Daniel; 2001, "Democratic Development in Azerbaijan and the Role of the Western Oil Industry, ” Central Asian Survey, vol.20, no.3, September.

Herman, Charles F., Charles W. Kegley, and James N. Rosenau, eds.; 1987, New Directions in the Study of Foreign Policy, Boston: Allen \& Unwin.

Hermann, Margaret G.; 1978, "Effects of Personal Characteristics of Political Leaders on Foreign Policy," in Why Nations Acts: Theoretical Perspectives for Comparative Foreign Policy Studies, Maurice A. East, Stephen A. Salmore, Charles F. Hermann, eds., Beverly Hills: Sage Publications. , and Joe F. Hagan; 1998, “International Decision Making:

Leadership Matters," Foreign Policy, 110. , ed.; 2001, “Leaders, Groups, and Coalitions: Understanding the People and Processes in Foreign Policymaking," special issue of International Studies Quarterly.

Herz, John; 1951, Political Realism and Political Idealism: A Study in Theories and Realities, Chicago: University of Chicago Press.

Herzig, Edmund; 1999, The New Caucasus: Armenia, Azerbaijan and Georgia, London: The Royal Institute of International Affairs.

Hewitt, George; 1999, “Abkhazia, Georgia and the Circassians (NW Caucasus)," Central Asian Survey, vol. 18, no. 4.

Hey, Jeanne A. K., ed.; 2003, Small States in World Politics: Explaining Foreign Policy Behavior, Boulder: Lynne Rienner.

Hill, Christopher; 2003, The Changing Politics of Foreign Policy, London: Palgrave Macmillan.

Hinnebusch, Raymond; 2003, The International Politics of the Middle East, Manchester: Manchester University Press.

Hoffman, David I.; 2000, “Azerbaijan: The Politicization of Oil," in Energy and Conflict in Central Asia and the Caucasus, Robert Ebel and Rajan Menon, eds., Lanham: Rowman \& Littlefield Publishers, Inc.

Hollis, Martin and Steve Smith; 1991, Explaining and Understanding International

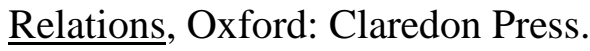


Holsti, K. J.; 1987, "National Role Conceptions in the Study of Foreign Policy,” in Role Theory and Foreign Policy Analysis Stephen G. Walker, ed., Durham: Duke University Press.

; 1996, The State, War, and State of War, Cambridge: Cambridge University

Press.

; 2004, Taming the Sovereigns: Institutional Change in International Politics, Cambridge: Cambridge University Press.

Holsti, Ole; 1975, “The Belief System and National Images: A Case Study," in Analyzing International Relations William D. Coplin and Charles W. Kegley, eds., New York: Praeger Publishers.

Hopf, Ted; 1998, "The Promise of Constructivism in International Relations Theory," International Security, vol. 23, no.1.

; 1999, Understandings of Russian Foreign Policy, University Park: The Pennsylvania State University Press.

; 2005, "Identity, Legitimacy, and the Use of Military Force: Russia's Great Power Identities and Military Intervention in Abkhazia," Review of International Studies, no. 31 .

Hopkins, A. G.; 2000, “Quasi-states, Weak States and the Partition of Africa," Review of International Studies, 26.

Hoiris, Ole and Sefa Martin Yurukel, eds., 1998, Contrasts and Solutions in the Caucasus, Aarhus: Aarhus University Press.

Hovannisian, Richard G.; 1982, The Republic of Armenia: From Versailles to London, 1919-1920, vol.2. , Berkeley: University of California Press. ; 1994, "Historical Memory and Foreign Relations," in The Legacy of History in Russia and the New States of Eurasia, S. Frederick Starr, ed., Armonk: M.E. Sharpe.

Hunter, Shireen T.; 1992, "Solve the Caucasus Crisis," Christian Science Monitor, 02 June.

; 1994, The Transcaucasus in Transition: Nation-Building and

Conflict, Washington, D.C.: The Center for Strategic \& International Studies. ; 1997, “Azerbaijan: Searching for New Neighbors," in New States, New Politics: Building the Post-Soviet Nations, Ian Bremmer and Ray Taras, eds., Cambridge: Cambridge University Press. 
; 2000, "The Evolution of the Foreign Policy of the Transcaucasian

States," in in Crossroads and Conflict: Security and Foreign Policy in the Caucasus and Central Asia, Gary K. Bertsch, et al., eds., New York: Routledge.

Huttenbach, Henry R.; 1995, "Chaos in Post-Soviet Caucasia, Crossroads of Empires: In Search of a U.S. Foreign Policy" in The Successor States to the USSR, John W. Blaney, ed., Washington, D.C.: Congressional Quarterly Inc.

Hyland, Francis; 1991, Armenian Terrorism: The Past, the Present, the Prospects, Boulder: Westview.

Ikenberry, G. John; 2001, After Victory: Institutions, Strategic Restraint, and the Rebuilding of Order After Major Wars, Princeton: Princeton University Press.

Isazade, Azad, 1997, “Armeniagate: Russia Arms One Side in the Armenian-Azerbaijani Conflict," War Report, May.

Ivantsov, Igor; 1995, "Fuel Minister Hails Decision on Caspian Oil Routes," ITARTASS World Service, 16 October.

Ivekovic, Ivan; 2000, Ethnic and Regional Conflicts in Yugoslavia and Transcaucasia: A Political Economy of Contemporary Ethnonational Mobilization, Ravenna: Longo Editore.

Jazbec, Milan; 2001, The Diplomacies of New Small States: The Case of Slovenia with Some Comparison from the Baltics, Aldershot: Ashgate.

Jenne, Erin K.; 2003, "Sri Lanka: A Fragmented State," in State Failure and State Weakness in a Time of Terror, Robert I. Rotberg, ed., Washington, D.C.: Brookings Institution Press.

Jensen, Lloyd; 1982, Explaining Foreign Policy, Englewood Cliffs: Prentice-Hall, Inc.

Jentleson, Bruce, ed.; 2000, Opportunities Missed, Opportunities Seized: Preventive Diplomacy in the Post-Cold War World, Lanham: Rowman \& Littlefield Publishers, Inc.

Jervis, Robert L.; 1976, Perception and Misperception in International Politics, Princeton: Princeton University Press.

; 1978, “Cooperation under the Security Dilemma," World Politics, January 1978, vol. 30, no. 2.

Johnson, Lena and Clive Archer, eds.; 1996, Peacekeeping and the Role of Russia in Eurasia, Boulder: Westview Press. 
Jones, Scott A.; 2000, "Introduction," in Crossroads and Conflict: Security and Foreign Policy in the Caucasus and Central Asia, Gary K. Brertsch, et al., eds., New York: Routledge. ; 2000, "Turkish Strategic Interests in the Transacaucasus," in Crossroads and Conflict: Security and Foreign Policy in the Caucasus and Central Asia, Gary K. Bertsch, et al., eds., New York: Routledge.

Jones, Stephen F.; 1993, “Georgia's Power Structures,” RFE/RL Research Report, 1 October, vol. 2, no. 39.

; 1997, "Georgia: The Trauma of Statehood," in New States, New Politics: Building the Post-Soviet Nations, Ian Bremmer and Ray Taras, eds., Cambridge: Cambridge University Press. ; 2002, "The Role of Cultural Paradigms in Georgian Foreign Policy," Journal of Communist Studies and Transition Politics, vol. 19, no. 3.

Jonson, Lena; 2001, "The New Geopolitical Situation in the Caspian Sea," in The Security of the Caspian Sea Region, Gennady Chufrin, ed., (Oxford: Oxford University Press.

; 2004, Vladimir Putin and Central Asia: The Shaping of Russian Foreign

Policy, London: I. B. Taurus.

Kaarbo, Juliet, and et al.; 2003, "The Analysis of Foreign Policy in Comparative Perspective," in Foreign Policy in Comparative Perspective: Domestic and International Influences on State Behavior, Ryan K. Beasley, et al., eds., Washington, D.C.: CQ Press.

Katzenstein, Peter J.; 1985, Small States in World Markets: Industrial Policy in Europe, Ithaca: Cornell University Press. , ed.; 1996, The Culture of National Security: Norms and Identity in World Politics, New York: Columbia University Press. , Robert O. Keohane, and Stephen D. Krasner; 1998, “International Organization and the Study of World Politics," International Organization, Autumn, 52, 4.

Kaufman, Stuart J.; 2001, Modern Hatreds: The Symbolic Politics of Ethnic War, Ithaca: Cornell University Press.

Kazimirov, Vladimir; 1999, "Nagorno-Karabakh: Five Years after the Cease-fire," International Affairs: A Russian Journal of World Politics, Diplomacy and International

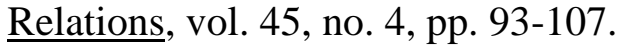


; 2000, "On the Karabakh Crisis, ” International Affairs: A

Russian Journal of World Politics, Diplomacy and International Relations, vol.46, no.4.

Kegley, Charles, Gregory A. Raymond, and the others, eds.; 1975, International Events and the Comparative Analysis of Foreign Policy, Columbia: University of South Carolina Press.

Keohane, Robert O.; 1984, After Hegemony: Cooperation and Discord in the World Political Economy, Princeton: Princeton University Press.

University Press. , ed.; 1986, Neorealism and its Critics, New York: Columbia

Khanbabyan, Armen; 1995, "Cooperation: A Russian Military Base in Armenia- Treaty Is Signed to Mutual Satisfaction,” Nezavisimiya Gazeta, 18 March.

; 1996, "Opening of the Border with Turkey is Beneficial for Both Sides," Nezavisimaya Gazeta, 20 August.

Khazanov, Anatoly M.; 1995, After the USSR: Ethnicity, Nationalism, and Politics in the Commonwealth of Independent States, Madison: The University of Wisconsin Press.

Khripunov, Igor and Mary M. Matthews; 1996, "Russia's Oil and Gas Interst Group and Its Foreign Policy Agenda," Problems of Post-Communism, May/June 1996, vol. 43, no. 3.

King, Charles; 2001, "The Benefits of Ethnic War: Understanding Eurasia's Unrecognized States," World Politics, July, vol. 53, no. 4. ; 2004, “A Rose among Thorns: Georgia Makes Good,” Foreign Affairs, March/April, vol.83, no. 2.

King, Gary, Robert O. Keohane, and Sidney Verba; 1994, Designing Social Inquiry: Scientific Inference in Qualitative Research, Princeton: Princeton University Press.

Kinzer, Stephen; 1997, "Azerbaijan Has Reason to Swagger: Oil Deposit," The New York Times, 14 September. ; 1998, “A Defiant Satellite, Georgia Finds Paternalistic Russia’s Orbit Inescapable," New York Times, 3 May.

Kortunov, A.; 1995, "Russia, the Near Abroad and the West," in The New Russia: Troubled Transformation, G. Lapidus, ed., Boulder: Westview Press, 1995. 
Kovalsky, Nikolai; 1994, “Russia and the Black Sea Region,” International Affairs: A Russian Journal of World Politics, Diplomacy and International Relations, no. 10.

Krasner, Stephen D.; 1978, Defending the National Interest: Raw Materials Investments and U.S. Foreign Policy, Princeton: Princeton University Press.

University Press. ; 1999, Sovereignty: Organized Hypocrisy, Princeton: Princeton

Krasulin, Aleksandr; 1995, "Two-Pipeline Solution for Azerbaijan Oil 'Temporary," Rossiyskaya Gazeta, 14 October.

Krause, Keith; 2003, "State-Making and Region-Building: The Interplay of Domestic and Regional Security in the Middle East," The Journal of Strategic Studies, September, vol. 26, no. 3 .

Kremenyuk, Viktor A.; 1994, Conflicts in and around Russia: Nation-building in Difficult Times, Westport: Greenwood Press.

Kubalkova, Vendulka, ed.; 2001, Foreign Policy in a Constructed World, Armonk: M. E. Sharpe.

Kut, Gun; 1993, "End of Elchibey is the end of the Turkish Model,” Cumhuriyet, 24 June.

Labs, Eric; 1997, "Beyond Victory: Offensive Realism and the Expansion of War Aims," Security Studies, vol. 6, no. 4.

Larrabee, F. Stephen, and Ian O. Lesser; 2003, Turkish Foreign Policy in an Age of Uncertainty, Santa Monica: RAND.

Larsen, Henrik; 1997, Foreign Policy and Discourse Analysis: France, Britain and Europe, London: Routledge.

Larson, Deborah W.; 1985, Origins of Containment: A Psychological Explanation, Princeton: Princeton University Press.

; 1997, Anatomy of Mistrust: U.S.- Soviet Relations During the Cold War, Ithaca: Cornell University Press.

Le Prestre, Philippe G., eds.; 1997, Role Quests in the Post-Cold War Era: Foreign Policies in Transition, Montreal: McGill-Queen's University Press.

LeVine, Steve; 1998, “Armenia Caught in Shifting Tide of World Politics," New York Times, 29 March. 
; 2007, Oil and the Glory: The Pursuit of Empire and Fortune on the

Caspian Sea, New York: Random House.

Lebow, Richard N.; 1997, "Small States and Big Alliances," American Political Science Review, September, vol. 91, no. 3 .

Leeuw, Charles van der; 1998, Storm Over the Caucasus: In the Wake of Independence, New York: St. Martin's Press. ; 2000, Azerbaijan a Quest for Identity: A Short History, Surrey:

Curzon.

Legro, Jeffrey W., and Andrew Moravcsik; 1999, "Is Anybody Still a Realist?"

International Security, Fall, 24, 2.

Legvold, Robert; 2005, "Outlining the Challenge," in Statehood and Security: Georgia after the Rose Revolution, Bruno Coppieters and Robert Legvold, eds., Cambridge: The MIT Press.

Leitzinger, Antero, ed.; 1997, Caucasus and an Unholy Alliance, Vantaa, Finland:

Leitzinger Books.

Lepingwell, John W. R.; 1993, “Restructuring the Russian Military,"RFE/RL Research Report, vol. 2, no. 55, 18 June.

; 1994, "The Russian Military and Security Policy in the 'New

Abroad'," Survival, Autumn, vol. 36, no. 3.

Libaridian, Gerard J.; 1999, The Challenge of Statehood: Armenian Political Thinking Since Independence, Watertown: Blue Crane Books.

; 2004, Modern Armenia: People, Nation, State, New Brunswick:

Transaction Publishers.

Lieven, Anatol; 2000, "Nightmare in the Caucasus," The Washington Quarterly, Winter 2000, vol.23, no.1.

Light, Margot; 1996, "Foreign Policy Thinking,"in Internal Factors in Russian Foreign Policy, Neil Malcolm, et al., eds., Oxford: Oxford University Press. ; 2003, "In Search of an Identity: Russian Foreign Policy and the End of Ideology," in Ideology and National Identity in Post-Communist Foreign Policies, Rick Fawn, ed., London: Frank Cass.

Lijphardt, Arendt; 1971, "Comparative Politics and Comparative Method," American Political Science Review, September, vol. 65, no. 3. 
Lo, Bobo; 2002, Russian Foreign Policy in the Post-Soviet Era: Reality, Illusion and Mythmaking, New York: Palgrave Macmillian.

Lukic, Reneo and Allen Lynch; 1996, Europe from the Balkans to the Urals: The Disintegration of Yugoslavia and the Soviet Union, Oxford: Oxford University Press.

Lukin, Vladimir; 1992, “Our Security Predicament,” Foreign Policy, Fall.

Lynch, Allen C.; 2001, "Realism of Russia's Foreign Policy," Europe-Asia Studies, vol. 51 , no. 1.

Lynch, Dov; 1998, The Conflict in Abkhazia: Dilemmas in Russian 'Peacekeeping' Policy, London: The Royal Institute of International Affairs, 1998.

; 2000, Russian Peacekeeping Strategies in the CIS: The Cases of Moldova, Georgia and Tajikistan, New York: St. Martin's Press.

MacFarlane, S. Neil; 1997, "Democratization, Nationalism and Regional Security in the Southern Caucasus," Government and Opposition, Summer, vol. 32, no. 3.

Maksimenko, Oleg; 1999, "Terrorists Seize Power in Armenia: Prime Minister and Parliamentary Speaker Are Killed," Kommersant, 28 October.

Malcolm, Neil; 1995, “Russian Foreign Policy Decision-making,” Russian Foreign Policy since 1990, Peter Shearman, ed., Boulder: Westview Press.

; 1996, “Foreign Policy Making,"in Internal Factors in Russian Foreign

Policy, Neil Malcolm, et al., eds., Oxford: Oxford University Press.

Mamedov, Rustam; 2001, “Baku's Oil Diplomacy,” International Affairs: A Russian Journal of World Politics, Diplomacy and International Relations, vol.47, no.3, pp.161-9.

Mamedov, Sokhbet; 1993, "Geidar Aliyev Urges That the Threat of Civil War Be Eliminated," Izvestia, 15 June.

; 1993, "New Flare-Up of War in Azerbaijan; Armenian Shells Burst on Iranian Territory,” Izvestia, 27 October.

; 1994, “Azerbaijan Opposes Establishment of Russian Military

Bases on Its Territory,” Izvestia, 7 April.

Izvestia, 25 October.

; 1994, "Russian Trail in Flight of Azerbaijani Ex-Prime Minister," 
Mansbach, Richard W.; 2000, The Global Puzzle: Issues and Actors in World Politics, $3^{\text {rd }}$ edition, Boston: Houghton Mifflin Company.

Mandelbaum, Michael, ed.; 1998, The New Russian Foreign Policy, New York: Council on Foreign Relations.

Maresca, John J.; 1995, “The New Silk Road,” Wall Street Journal, 26 January. ; 1998, “U.S. Ban on Aid to Azerbaijan (Section 907): How It Started in 1992 and Why It Should be Lifted," Azerbaijan International, Winter, vol. 6, no. 4.

Markarov, Alexander; 2006, "Macro Institutional Political Structures and Their Development in Armenia," Demokratizatsiya, Spring, vol. 14, no. 2.

Masih, Joseph R., and Robert O. Krikorian; 1999, Armenia: At the Crossroads, Amsterdam: Harwood Academic Publishers.

Matevosyan, Gamlet; 1998, "Armenia Is Left without A President: Parliament Supports Resignation of Levon Ter-Petrosyan," Sevodnya, 5 February.

Matveeva, Anna; 2002, "Georgia: Peace Remains Elusive in Ethnic Patchwork," in Searching for Peace in Europe and Eurasia: An Overview of Conflict Prevention and Peacebuilding Activities, ed. by Paul Van Tongeren, et. al, Boulder: Lynne Rienner Publisher.

; 2002, "Nagorno Karabakh: A Straightforward Territorial Conflict," in Searching for Peace in Europe and Eurasia: An Overview of Conflict Prevention and Peacebuilding Activities, Paul Von Tongeren, Hans Van De Veen, and Juliette Verhoeven, eds., Boulder: Lynne Rienner Publishers.

Maynes, Charles W.; 1993, “Containing Ethnic Conflict,” Foreign Policy, Spring, no. 90.

Mearsheimer, John J.; 1990, "Back to Future: Instability in Europe after the Cold War," International Security, Summer, vol. 15, no. 4.

; 1994/1995, "The False Promise of International Institutions," International Security, vol. 19, no. 3.

Norton and Company.

; 2001, The Tragedy of Great Power Politics, New York: W. W.

Medvedev, Sergei; 1999, "Power, Space, and Russian Foreign Policy," in

Understandings of Russian Foreign Policy, Ted Hopf, ed., University Park: The

Pennsylvania State University Press. 
; 2004, Rethinking the National Interest: Putin's Turn in Russian

Foreign Policy, Marshall Center Paper, August, no. 6.

Mekhtiyev, Aidyn; 1993, “Azerbaijan: Insurgents Seize Five Districts in the Republic:

Geidar Aliyev Continues Talks with the Rebels," Nezavisimaya Gazeta, 15 June.

Menon, Rajan; 1995, "In the Shadow of the Bear: Security in Post-Soviet Central Asia," International Security, Summer, vol. 20, no. 1.

; 1998, "After Empire: Russia and the Southern 'Near Abroad'," in The

New Russian Foreign Policy, Michael Mandelbaum, ed., New York: Council of Foreign Relations.

, and Hendrik Spruyt; 1998, "Possibilities for Conflict and Conflict

Resolution in post-Soviet Central Asia," in Post-Soviet Political Order: Conflict and State

Building, Barnett R. Rubin and Jack Synder, eds., London: Routledge.

, Yuri E. Fedorov and Ghia Nodia; eds.; 1999, Russia, the Caucasus, and

Central Asia: The $21^{\text {st }}$ Century Security Environment, Armonk: M.E. Sharpe.

, and Hendrik Spruyt; 1999, "The Limits of Neorealism: Understanding

Security in Central Asia," Review of International Studies, vol. 25.

Meshabi, Mohiaddin, ed.; 1994, Central Asia and the Caucasus After the Soviet Union:

Domestic and International Dynamics, Gainesville: University Press of Florida.

Mezel, Marcus; 2003, Doomed to Cooperate? American Foreign Policy in the Caspian

Region, Berlin: Peter Lang.

Migdal, Joe S.; 1988, Strong Societies and Weak States: State-Society Relations and

State Capabilities in the Third World, Princeton: Princeton University Press.

Mihalkanin, Edward; 2004, "The Abkhazians: A National Minority in Their Own

Homeland," in De Facto States: The Quest for Sovereignty, London: Routledge.

Mikoyan, Sergo A.; 1998, "Russia, the US and Regional Conflict in Eurasia," Survival, Autumn, vol. 40, no.3.

Milner, Helen V.; 1997, Interests, Institutions and Information: Domestic Politics and International Relations, Princeton: Princeton University Press.

Moon, Bruce E.; 1983, “The Foreign Policy of the Dependent State," International Studies Quarterly, September, vol. 27, no. 3.

; 1985, "Consensus or Compliance? Foreign-Policy Change and External Dependence," International Organization, Spring, vol. 39, no. 2. 
Moravcsik, Andrew; 1997, "Taking Preferences Seriously: A Liberal Theory of International Politics,” International Organization, Autumn, vol. 51, no. 4.

Morgenthau, Hans; 1993, Politics Among Nations: The Struggle for Power and Peace, New York: McGraw-Hill.

Morningstar, Richard Morningstar; 1998, "U.S. Energy Policy toward the Caspian Basin," CERA Conferences, Washington, D. C., 7 December, www.mtholyoke.edu/acad/intrel/morning.htm.

Motly, Alexander J.; 1999, Revolutions, Nations, Empires: Conceptual Limits and Theoretical Possibilities, New York: Columbia University Press. ; 2001, Imperial Ends: The Decay, Collapse, and Revival of Empires, New York: Columbia University Press.

Mouradian, Claude; 1991, "The Mountainous Karabagh Question: An Interethnic Conflict or Decolonization Crisis?” Armenian Review, Winter, vol. 32, no. 1.

Mozaffari, Mehdi; 1997, Security Politics in the Commonwealth of Independent States: Southern Belt, New York: St. Martin's Press.

Nasibli, Nasib; 1999, “Azerbaijan: Oil and Politics in the Country's Future," in Oil and Geopolitics in the Caspian Sea Region, Michael P. Croissant and Bulent Aras, eds., Westport: Praeger.

Naumkin, Vitaly; 1998, "Russia and Transcaucasia," Caucasus Regional Studies, vol.3, no.1, http://polipc14.vub.ac.be/publi/crc/eng/0301-00.htm.

Nichol, James P.; 1995, Diplomacy in the Former Soviet Republics, Westport: Praeger.

Nichol, Jim; 2008, "Armenia, Azerbaijan, and Georgia: Security Issues and Implications for U.S. Interest," Congressional Research Service, 31 January.

Nodia, Ghia; 1998, "Causes and Visions of Conflict in Abkhazia," Berkeley: Berkeley Program in Soviet and Post-Soviet Studies Working Paper Series. ; 1998, "Dynamics of State-Building in Georgia," Demokratizatsiya, Winter 1998, vol. 6, no. 1. ; 2000, "A New Cycle of Insecurity in Georgia: New Troubles and Old Problems," in Crossroads and Conflict: Security and Foreign Policy in the Caucasus and Central Asia, Gary K. Bertsch, et al., eds., New York: Routledge. 
Nuriyev, Elkhan E.; 2000, "Conflicts, Caspian Oil, and NATO: Major Pieces of the Caucasus Puzzle," in Crossroads and Conflicts: Security and Foreign Policy in the

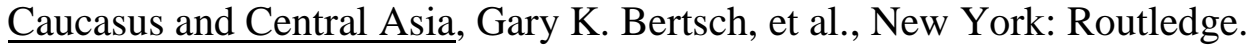
; 2000, The Post-Soviet Caucasus within New Geopolitical

Framework: Towards Conflicts or Peace? Bonn: Arbeitsstelle Friedenforschung Bonn (AFB)-Texte Series, no. 3

Nye, Joseph and Robert Keohane; 2001, Power and Interdependence, $3^{\text {rd }}$ edition, New York: Longman.

Nygren, Bertil; 2008, The Rebuilding of Greater Russia: Putin's Foreign Policy towards the CIS Countries, New York: Routledge.

Odom, William E.; 1995, Commonwealth or Empire? Russia, Central Asia and Transcaucasus, Indianapolis: Hudson Institute.

Ogan, Sinan and Kamil Agacan; 2001, “Guney Kafkasya'da Yeniden Baslayan veya Bitmeyen Soguk Savas, ” Stratejik Analiz, cilt 2, sayi 13.

News, 13 March. ; 2002, "Gabala Radar Station: Somebody is Watching Us," Turkish Daily

Oke, Mim Kemal; 1988, The Armenian Question 1914-1923, Oxford: K. Rustem \& Brother.

Olcott, Martha B.; 1995, "Sovereignty and the 'Near Abroad'," Orbis, Summer, vol. 39, no. 3 .

; Anders Aslund and Sherman W. Garnett, 1999, Getting It Wrong:

Regional Cooperation and the Commonwealth of Independent States, Washington, D.C.: Carnegie Endowment for International Peace.

Owen, John, 1994, “How Liberalism Produces Democratic Peace, ” International Security, Fall, vol. 19, no. 2.

Oye, Kenneth A., ed.; 1986, Cooperation under Anarchy ,Princeton: Princeton University Press.

Oyliyeva, Yelena; 1997, "Aliyev Promises Caspian Oil to Ankara. Absence of Peace Treaty with Chechnya Cuts Russian Oil Route," Kommersant, 7 May.

Ozdag, Umit; 1996, “From USSR to Russian Federation,” Avrasya Dosyasi, 3, 4, Winter. 
Pain, Emil I.; 1999, "Contagious Ethnic Conflicts and Border Disputes along Russia's Southern Flank," in Russia, the Caucasus and Central Asia: The $21^{\text {st }}$ Century Security Environment, Rajan Menon, et al., eds., Armonk: M. E. Sharpe.

Pamir, Necdet; 2001, Baku-Ceyhan Boru Hatti Ortaasya ve Kafkasya'da Bitmeyen Oyun, Ankara: ASAM.

Panossian, Razmik; 2005, "Homeland-Diaspora Relations and Identity Differences," in The Armenians: Past and Present in the Making National Identity, Edmund Herzig and Marina Kurkchiyan, eds., London: Routledge.

; 2006, The Armenians: From Kings and Priests to Merchants and

Commissars, New York: Columbia University Press. ; 2006, "Post-Soviet Armenia: Nationalism \& Its (Dis)contents," in Making and Protecting the Nation in Postcolonial \& Postcommunist States, Lowell W. Barrington, ed., Ann Arbor: The University of Michigan Press.

Papazian, Taline; 2006, "From Ter-Petrossian to Kocharian: Explaining Continuity in Armenia Foreign Policy, 1991-2003,” Demokratizatsiya, Spring, vol. 14, no. 2.

Parrott, Bruce; 1995, State-building and Military Power in Russia and the New States of Eurasia, Armonk: M. E. Sharpe.

Pashayev, Hafiz; 2006, Racing Up Hill: Selected Papers of Azerbaijan's First Ambassador to the United States of America, New York: Global Scholarly Publications.

Payaslian, Simon; 2007, The History of Armenia: From the Origins to the Present, New York: Palgrave Macmillian.

Peimani, Hooman; 1998, Regional Security and the Future of Central Asia: The Competition of Iran, Turkey and Russia, Westport: Praeger.

Persaud, Randolph B.; 2001, Counter-Hegemony and Foreign Policy: The Dialectics of Marginalized and Global Forces in Jamaica, New York: State University of New York Press.

Petersen, Philip; 1994, "Security Policy in Post-Soviet Transcaucasia", European Security, Spring, vol. 3, no. 1.

Petrosyan, David; 1997, “Will Azerbaijan-Turkey Oil Pipeline Traverse Armenia?" Review \& Outlook, 18 November.

Phillips, David L.; 2005, Unsilencing the Past: Track Two Diplomacy and TurkishArmenian Reconciliation, New York: Berghahn. 
Polukhov, Elkhan; 1996, "Contract of the Century: The Problem in an Historical Retrospective, "Caucasian Regional Studies, no.1, http://pubs.carnegie.ru/CRS/publi/crs/eng/0201-05.htm.

Pope, Hugh; 1997, "Great Game II: Oil Companies Rush into the Caucasus to Tap the Caspian,” The Wall Street Journal, 25 April.

Popov, Arkadii; 1997, "Ethnic Wars in the Caucasus," In Mark Kaldor and Basker Vashee, eds., Restructuring the Global Military Sector, London: Pinter.

Prizel, Ilya; 1995, National Identity and Foreign Policy: Nationalism and Leadership in Poland, Russia, and Ukraine, Cambridge: Cambridge University Press.

Putnam, Robert D.; 1988, "Diplomacy and Domestic Politics: The Logic of Two Level Games," International Organization Summer, 42.

Ra'anan, Uri, and Kate Martin, eds.; 1995, Russia: A Return to Imperialism, New York: St. Martin's Press.

Ragin, Charles C.; 1994, Constructing Social Research, London: Pine Forge Press.

Rasizade, Alec; 2002, "Azerbaijan after a Decade of Independence: Less Oil, More Graft and Poverty," Central Asian Survey, December, vol. 21, no. 4.

Remnick, David; 1991, “Azerbaijanis Cast Ballots for President: Incumbent Unopposed in Soviet Republic," Washington Post, 9 September.

Renshon, Stanley A., and Deborah W. Larson, eds.; 2003, Good Judgment in Foreign Policy: Theory and Application, Lanham; Rowman \& Littlefield.

Richardson, Neil R.; 1978, Foreign Policy and Economic Dependence, Austin: University of Texas Press. and Charles Kegley; 1980, "Trade Dependence and Foreign Policy Compliance: A Longitudinal Analysis,” International Studies Quarterly, 24.

Rieff, David; 1997, “Case Study in Ethnic Strife," Foreign Affairs, March/April, vol. 76, no. 12.

Rise- Kappen, Thomas; 1991, "Public Opinion, Domestic Structure, and Foreign Policy in Liberal Democracies," World Politics, 43/44.

Rivera, David W.; 2000, "Liberalism and the Suppression of Russian Imperialism: War and Peace in Post-Soviet Eurasia," a paper presented at the 2000 Annual Meeting of the American Political Science Association. 
Roberts, John; 2001, "Energy Reserves, Pipelines Routes and the Legal Regime in the Caspian Sea," in The Security of the Caspian Sea Region, Gennady Chufrin, ed., Oxford: Oxford University Press.

; 2004, "Pipeline Politics," in The Caspian: Politics, Energy, and Security, Shirin Akiner, ed., London: Routledge Curzon.

Robins, Philip; 1993, “Between Sentiment and Self-Interest: Turkey's Policy toward Azerbaijan and the Central Asian States," Middle East Journal, Autumn, vol. 47, no. 4. ; 2003, Suits and Uniforms: Turkish Foreign Policy Since the Cold War,

London: Hurst \& Company.

Rondeli, Alexander; 1996, “Georgia in the Post-Soviet Space," Caucasian Regional Studies, no.1, http://pubs.carnegie.ru/CRS/publi/crs/eng/0101-07.htm

; 2001, "The Choice of Independent Georgia," in The Security of the Caspian Sea Region, Gennady Chufrin, ed., Oxford: Oxford University Press.

Rosati, Jerel A., Joe D. Hagan and the others, eds.; 1994, Foreign Policy Restructuring: How Governments Respond to Global Change, Columbia: University of South Carolina Press.

Rose, Gideon; 1998, "Neoclassical Realism and Theories of Foreign Policy," World Politics, vol. 51, no. 1.

Rosenau, James N.; 1969, Linkage Politics: Essays on the Convergence of National and International Systems, New York: Free Press. , ed.; 1974, Comparing Foreign Policies: Theories, Findings, and Methods, New York: John Wiley \& Sons.

Rotberg, Robert I.; 2002, “The New Nature of Nation State Failure," The Washington Quarterly, Summer, vol. 25, no. 3.

; 2003, "Failed States, Collapsed States, Weak States: Causes and Indicators," in State Failure and State Weakness in Time of Terror, Robert I. Rotberg, ed., Washington, D.C.: Brookings Institution Press. ; 2004, "The Failure and Collapse of Nation-States: Breakdown, Prevention, and Repair," in When States Fail: Causes and Consequences, Robert I. Rotberg, eds., Princeton: Princeton University Press.

Rothstein, Robert L.; 1968, Alliances and Small Powers, New York: Columbia University Press. 
Rubin, Barnett R. and Jack Synder, eds.; 1998, Post-Soviet Order: Conflict and State Building, London: Routledge.

Rubinstein, Alvin Z.; 1977, Red Star on the Nile: The Soviet-Egyptian Influence Relationship since the June War, Princeton: Princeton University Press.

Ruggie, John G.; 1998, Constructing the World Polity: Essays on International Institutionalization, London: Routledge.

Ruseckas, Laurent; 2000, "Turkey and Eurasia: Opportunities and Risks in the Caspian Pipeline Derby, ” Journal of International Affairs, vol.54, no.1.

Russett, Bruce M.; 1970, "International Behavior Research: Case Studies and Cumulation," in Approaches to the Study of Political Science, Michael Haas and Henry S. Kariel, eds., Scranton: Chandler Publishing Company.

Sabanadze, Natalie; 2002, "International Involvement in South Caucasus," ECMI Working Paper, 15, http://www.ecmi.de/doc/download/working_paper_15.pdf.

Safarly, Mamed; 1994, "Teheran and Baku: Conflicts against Backdrop of GoodNeighbor Relations,” Nezavisimaya Gazeta, 5 July.

Safizadeh, Fereydoun; 1998, "On Dilemmas of Identity in the Post-Soviet Republic of Azerbaijan," Caucasian Regional Studies, vol.3, no.1, 1998, http://poli.vub.ac.be/publi/crs/eng/0301-04.htm

Saideman, Stephen M.; 2001, The Ties That Divide: Ethnic Politics, Foreign Policy, and International Conflict, New York: Columbia University Press.

Sassounian, Harut; 1997, "How Long Can Armenia Continue Ignoring Negative Publicity?" California Courier Publisher, 15 April.

Schatz, Edward; 2005, Modern Clan Politics: The Power of Blood in Kazakhstan and Beyond, Seattle: University of Washington Press.

Schweller, Randall; 1994, "Bandwagoning for Profit: Bringing the Revisionist State Back In, " in International Security, Summer, vol. 19, no.1. ; 1996, "Neorealism's Status-Quo Bias: What Security Dilemma?"

Security Studies, vol. 5, no. 3. ; 1998, Deadly Imbalances: Tripolarity and Hitler's Strategy of World Conquest, New York: Columbia University Press.

Schou, August and Arne Olav Brundtland, eds.; 1970, Small States in International Relations, New York: John Wiley \& Sons, Inc. 
Sezer, Duygu B.; 1997, "From Hegemony to Pluralism: The Changing Politics of the Black Sea,” SAIS Review, 17, 1.

Shaffer, Brenda; 2001, "The Caucasus and Caspian Region: Understanding United States Policy, ” House Committee on International Relations, Subcommittee on Europe, Testimony, 10 October.

; 2002, Borders and Brethren: Iran and the Challenge of Azerbaijani Identity, Cambridge: The MIT Press.

Shashenkov, Maxim; 1997, "Russia in the Caucasus: Interests, Threats and Policy Options," in Russia and Europe: The Emerging Security Agenda, Vladimir Baranovsky, ed., Oxford: Oxford University Press.

Sheets, Lawrence; 1997, "Armenian Policy Switch Fuels Talk of Karabagh Deal," Reuters, 23 October.

Sieff, Martin; 1997, “Armenia Armed by Russia for Battles with Azerbaijan,” The Washington Times, 10 April.

Singer, Marshall R.; 1972, Weak States in a World of Powers: The Dynamic of International Relationships, New York: The Free Press.

Skak, Mette; 1996, Postcommunist Foreign Policy and International Relations, New York: St. Martin's Press.

Skopcol, Theda; 1985, "Bringing the State Back in: Strategies of Analysis in Current Research," in Bringing the State Back in, Peter B. Evans, Dietrich Rueschemeyer, and Theda Skopcol, eds., Cambridge: Cambridge University Press.

Smith, Mark; 1993, Pax Russica: Russia’s Monroe Doctrine, London: Royal United Services Institute.

Smith, Graham, Vivien Law, Andrew Wilson, Annette Bohr and Edward Allworth; 1998, Nation-Building in the Post-Soviet Borderlands: The Politics of National Identities, Cambridge: Cambridge University Press.

Smith, Steve; 2001, "Foreign Policy is What States Make of It: Social Construction and International Relations Theory," in Foreign Policy in a Constructed World, Vendulka Kubalkova, ed., Armonk: M. E. Sharpe.

Sneider, Daniel; 1993, "Big Power Rivalry in the Caucasus," Christian Science Monitor, 22 July. 
Socor, Vladimir, Elizabeth Teague, and Stephen Foye, 1998, "More Facts on U.S.Georgian Military Cooperation Revealed," Jamestown Foundation Monitor, 1 April. , Elizabeth Teague, and Stephen Foye; 1998, "Georgia-U.S. Military Cooperation Program Signed," Jamestown Foundation Monitor, 11 November.

Specter, Michael; 1997, “Drift to Dictatorship Clouds Armenia's Happiness, ” New York Times, 03 January.

Stanislaw, Joseph and Daniel Yergin; 1993, "Oil: Reopening the Door," Foreign Affairs, September/October, vol. 72, no. 4.

Starr, S. Frederick; ed.; 1995, The Legacy of History in Russia and the New States of Eurasia, Armonk: M.E. Sharpe.

Starr, S. Frederick; 1997, "Power Failure: American Policy in the Caspian," The National Interest, Spring.

Stinchcombe, Arthur L.; 1968, Constructing Social Theories, New York: Harcourt, Brace \& World.

Suny, Ronald G.; 1993, The Revenge of the Past: Nationalism, Revolution, and the Collapse of the Soviet Union, Stanford: Stanford University Press.

; 1993, Looking toward Ararat: Armenia in Modern History,

Bloomington: Indiana University Press.

; 1994, The Making of the Georgian Nation, $2^{\text {nd }}$ edition, Bloomington: Indiana University Press.

;1996, Transcaucasia, Nationalism, and Social Change: Essays in the History of Armenia, Azerbaijan, and Georgia, Ann Arbor: The University of Michigan Press. ; 1999, "Southern Tears: Dangerous Opportunities in the Caucasus and Central Asia," in Russia, the Caucasus and Central Asia: The 21st Century Security Environment, Rajan Menon, et al., eds., Armonk: M. E. Sharpe.

Swietochowski, Tadeusz; 1994, “Azerbaijan's Trianglar Relationship: The Land between Russia, Turkey and Iran," The New Geopolitics of Central Asia and Its Borderlands, Ali Banuazizi and Myran Weiner, eds., Bloomington: Indiana University Press. ; 1994, "Azerbaijan: A Borderland at the Crossroads of History," in The Legacy of History in Russia and the News States of Eurasia, S. Frederick Starr, eds., Armonk: M. E. Sharpe. 
; 1995, Russia and Azerbaijan: A Borderland in Transition,

New York: Columbia University Press.

Sylvan, Donald A. and Steve Chan, eds.; 1984, Foreign Policy Decision Making:

Perception, Cognition, and Artificial Intelligence, New York: Praeger.

Sylvan, Donald A., James F. Voss, eds.; 1998, Problem Representation in Foreign Policy Decision Making, Cambridge: Cambridge University Press.

Synder, Glenn; 1997, Alliance Politics, Ithaca: Cornell University Press.

Synder, Jack; 1991, Myths of Empire: Domestic Politics and International Ambition, Ithaca: Cornell University Press.

; 1998, "Introduction: Reconstructing Politics amidst the Wreckage of

Empire," in Post-Soviet Political Order: Conflict and State Building, Barnett R. Rubin and Jack Synder, eds., London: Routledge.

Synder, Richard C., H. W. Bruck, and Burton Sapin, eds.; 1962, Foreign Policy DecisionMaking: An Approach to the Study of International Politics, New York: Free Press of Glencoe.

Szporluk, Roman, ed.; 1994, National Identity and Ethnicity in Russia and the New States of Eurasia, Armonk: M. E. Sharpe.

Talbott, Strobe; 1995, “Celebrating a New Future for Armenia," US Department of State Dispatch, 12 June, vol. 6, no. 24.

Taranov, Sergei; 1992, “Azerbaijani Units Go on the Offensive: Ayaz Muttalibov's Resignation Intensifies War,” Izvestia, 7 March.

Tchilingirian, Hratch; 1999, "The Istanbul Summit: Fifty-Four Nations Discuss Regional Security and Conflict," Armenian International Magazine, 31 December, vol. 10, no. 12.

Ter-Gabrielyan, Gevorg; 2007, "Making History on Parallel Tracks: Yeltsin, TerPetrossian, and the Emergence of Democracy in the Post-Soviet Era," The Armenian Reporter, 5 May.

Tilly, Charles; 2005, Identities, Boundaries, and Social Ties, Boulder: Paradigm Publishers.

Tolz, Vera; 1992, "Russia: Westernizers Continue to Challenge National Patriots," RFE/RL Research Report, 11 December. 
Tsygankov, Andrei P.; 1999, "Farewell to the Empire? National Identity and Varieties of State Foreign Economic Policies in the Former Soviet Region," in International Studies Association Annual Meeting, Washington, D.C.

; 2001, Pathways After Empire: National Identity and Foreign

Economic Policy in the Post-Soviet World, Lanham: Rowman \& Littlefield Publishers, Inc.

,2006, Russia's Foreign Policy: Change and Continuity in National

Identity, Lanham: Rowman \& Littlefield Publishers, Inc.

Tutuncu, Mehmet; 1997, “Turkey's Foreign Policy in the Caucasus," Turkistan

Newsletter, Special Issue, 23 June, vol. 97-1, no. 14a.

, ed.; 1998, Caucasus: War and Peace: New World Disorder in

Caucasia, Haarlem: SOTA.

Useynov, Arif; 1995, “U.S. Envoy on Priorities in Caspian Oil Transport,” Sevodnya, 30 September.

; 1995, "Pipeline Routes Run Across Big-Time Politics. The Fight for Control of Oil Transportation Has Only Begun," Sevodnya, 11 October.

Van Evera, Stephen; 1997, Guide to Methodology for Students of Political Science, Ithaca: Cornell University Press.

; 1999, Causes of War: Power and the Roots of Conflict, Ithaca:

Cornell University Press.

Vasquez, John A., and Colin Elman, eds.; 2003, Realism and the Balancing of Power: A New Debate, Upper Saddle River: Prentice Hall.

Vassilieva, Olga; 2003, "Conflict Management in the Caucasus via Development of Regional Identity," in Potentials of Disorder, Jan Koehler and Christoph Zurcher, eds., Manchester: Manchester University Press.

Volgy, Thomas J., and Alison Bailin; 2003, International Politics and State Strength, Boulder: Lynne Rienner.

Volkan, Vamik; 1998, Bloodlines: From Ethnic Pride to Ethnic Terrorism, Boulder: Westview Press.

; 2006, Killing in the Name of Identity: A Study of Bloody Conflicts,

Charlottesville: Pitchstone Publishing.

Waal, Thomas De; 1994, “Georgia Accord Attacked," The Moscow Times, 5 February. 
; 2003, Black Garden: Armenia and Azerbaijan through Peace and War, New York: New York University Press.

Walker, Edward W.; 1998, No Peace, No War in the Caucasus: Secessionist Conflicts in Chechnya, Abkhazia and Nagorno-Karabakh, Cambridge, MA: Strengthening Democratic Institutions Project, Harvard University. ; 1998, "Armenia's Constitutional Coup and the Karabakh Conflict," Analysis of Current Events, March/April, vol. 10, no. 3-4, http://socrates.berkeley.edu/ bsp/caucasus/articles.html. ; 2000, "No War, No Peace in the Caucasus: Contested Sovereignty in Chechnya, Abkhazia, and Karabakh," in Crossroads and Conflict: Security and Foreign Policy in the Caucasus and Central Asia, Gary K. Bertsch, et al. eds., New York: Routledge.

Walker, Stephen G., ed.; 1987, Role Theory and Foreign Policy Analysis, Durham: Duke University Press.

Wallace, William; 1971, Foreign Policy and the Political Process, London: Macmillan.

Wallander, Celeste A.; 1996, The Source of Russian Foreign Policy After the Cold War, Boulder: Westview Press. ; 2007, "Russian Transimperialism and Its Implications," The Washington Quarterly, Spring, vol. 30, no. 2.

Waller, Michael, Bruno Cooppieters and Alexei Malashenko; 1998, Conflicting Loyalites and the State in Post-Soviet Russia and Eurasia, London: Frank Cass.

Walldorf, Charles W.; 1996, Small States in International Affairs: Russian Relations with Azerbaijan and Tajikistan 1993-1994, Master Thesis at the University of Virginia.

Walt, Stephen M.; 1987, The Origins of Alliances, Ithaca: Cornell University Press. ; 1988, "Testing Theories of Alliance Formation: The Case of Southwest Asia," International Organization, 43.

Waltz, Kenneth N.; 1959, Man, the State, and War, New York: Columbia University Press. ; 1979, Theory of International Politics, New York: McGraw-Hill, Inc. 
; 1996, “International Politics is not Foreign Policy,” Security Studies,

vol. 6 .

Weisbrode, Kenneth; 2001, Central Eurasia: Prize or Quicksand?: Contending Views of Instability in Karabakh, Ferghana and Afghanistan, Oxford: The International Institute for Strategic Studies.

Wendt, Alexander; 1992, “Anarchy is What States Make of It,” International Organization, vol. 46.

; 1994, "Collective Identity Formation and the International State,"

American Political Science Review, June, vol. 88, no. 2.

University Press.

; 1999, Social Theory of International Politics, Cambridge: Cambridge

Wheatley, Jonathan; 2005, Georgia from National Awakening to Rose Revolution:

Delayed Transition in the Former Soviet Union, Burlington: Ashgate.

Wight, Martin; 1995, “The Pattern of Power," in Power Politics, Hedley Bull and C.

Holbran, eds., London: Leicester University Press.

Wilkenfeld, Jonathan, Gerald W. Hopple, and the others; 1980, Foreign Policy Behavior: The Interstate Behavior Analysis Model, London: Sage Publications.

Willerton, John P., and Geoffrey Cockerham; 2003, "Russia, the CIS and Eurasian Interconnections," in Limiting Institutions? The Challenge of Eurasian Security Governance, James Sperling, et al., eds., Manchester: Manchester University Press.

Williams, Selina; 1997, “Holdout Imperils Talks on Caucasus,” Los Angeles Times, 17 December.

Winrow, Gareth; 2000, Turkey and the Caucasus: Domestic Interests and Security Concerns, London: The Royal Institute of International Affairs.

Wittkopf, Eugene R.; 1973, "Foreign Aid and United Nations Votes: A Comparative Study," American Political Science Review, no. 67.

Woff, Richard; 1993, “The Armed Forces of Azerbaijan,” Jane’s Intelligence Review, October, vol. 5, no. 10.

Wohlforth, William C.; 1999, "The Stability of Unipolar World," International Security, Summer, vol. 24, no. 1.

Yalcinkaya, Alaeddin, ed.; 1998, Turk Cumhuriyetleri ve Petrol Boru Hatlari, Istanbul: Baglam Yayinlari. 
Yin, Robert K.; 1994, Case Study Research: Design and Methods, $2^{\text {nd }}$ ed., Thousand Oaks: Sage.

Yurukel, Sefa M.; 1998, "Nationalism and the Foundation of National Identity in Azerbaijan- Past and Present," in Contrasts and Solutions in the Caucasus, Ole Hoiris and Sefa M. Yurukel, eds., Aarhus: Aarhus University Press.

Yunusov, Arif; 1999, "The Southern Caucasus: Cooperation or Conflict?" in Building Security in Europe's New Borderlands: Subregional Cooperation in the Wider Europe, Renata Dwan, ed., Armonk: M. E. Sharpe.

Zagorski, Andrei V.; 1999, "Traditional Russian Security Interests in the Caucasus and Central Asia: Perceptions and Realities," in Russia, the Caucasus, and Central Asia: The $21^{\text {st }}$ Century Security Environment, Armonk: M.E. Sharpe.

Zahariadis, Nikolas; 1994, "Nationalism and Small State Foreign Policy: The Greek Response to the Macedonian Issue," Political Science Quarterly, Autumn, vol. 109, no. 4.

Zurcher, Christopher; 2003, "Georgia's Time of Troubles, 1989-1993," in Statehood and Security: Georgia after the Rose Revolution, Bruno Coppieters and Robert Legvold, eds., Cambridge: The MIT Press.

\section{Newspapers and News Agencies}

Armenian Reporter International

Armenpress News Agency

Associated Press

Azadliq

Azerbaijan International

Business Week

California Courier Publisher

Christian Science Monitor

Cumhuriyet

Current Digest of the Post-Soviet Press

Economist

EurasiaNet Weekly 
Foreign Broadcast Information Service (FBIS) Daily Report

\section{FBIS-SOV, FBIS-WEU}

FBIS Report: Central Eurasia

Hurriyet

Institute for War \& Peace Reporting Caucasus Reporting Service

Interfax

International Herald Tribune

ITAR-TASS World Services

Izvestia

Jamestown Foundation Monitor

Kommersant-Daily

Le Figaro

Los Angeles Times

Milliyet

Moscow News

Moscow Times

Nezavisimiya Gazeta

Omri Program Brief

OpenDemocracy

Reuters

Review \& Outlook

RFE/RL Newsline

RFE/RL Research Reports

Rossiyskaya Gazeta

Sakinform 
Sevodnya

Today Zaman

Turan

Turkish Daily News

Wall Street Journal

Washington Post

Washington Times

$\underline{\text { E-mail Lists }}$

Armenian News Network groong@usc.edu

Azerbaijani_studies@yahoogroups.com

CDI Russian E-mail List- http://www.cdi.org/russia

Johnson E-mail List- http://www.cdi.org/russia/johnson 